\title{
INESE ŠŪPULE
}

\section{LATVIJAS AUGSTI IZGLITTOTIE EMIGRANTI: IZGLĪTITBAS UN DARBA PIEREDZE LATVIJĀ UN ĀRVALSTĪS}


Inese Šūpule. Latvijas augsti izglītotie emigranti: izglîtības un darba pieredze Latvijā un ārvalstīs. Rīga: LU, 2020. 208 Ipp.

Latvia's highly educated emigrants: education and work experience in Latvia and abroad

https://doi.org/10.22364/laize

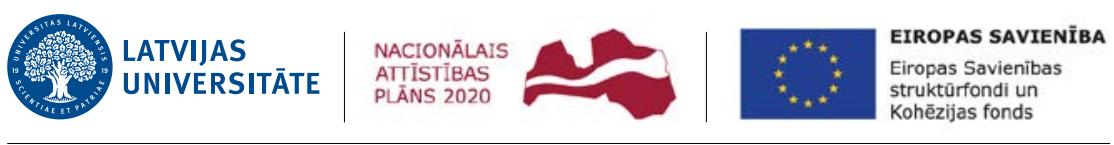

I E G L D $\bar{I} J U M S T A V \bar{A} N \bar{A} K O T N \bar{E}$

Monogrāfija izstrādāta un izdota ar Eiropas Reǵionālā attīstības fonda finansiālu atbalstu 1.1.1.2. pasākuma "Pēcdoktorantūras pētniecības atbalsts" ietvaros, projekts "Augsti kvalificētu speciālistu migrācijas izpēte: emigrācija un atgriešanās Latvijā" (Nr. 1.1.1.2/VIAA/1/16/012).
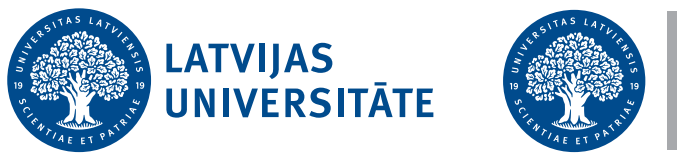

LATVIJAS UNIVERSITĀTE

FILOZOFIJAS UN

SOCIOLOG̦IJAS

INSTITŪTS

Monogrāiija apspriesta un rekomendēta publicēšanai Latvijas Universitātes Filozofijas un socioloǵijas institūta Zinātniskās padomes sēdē 2020. gada 30. jūnijā.

Zinātniskie recenzenti:

Inta Mierina, Dr. sc. soc., Diasporas un migrācijas pētijumu centrs

Ritma Rungule, Dr. sc. soc., Rīgas Stradiṇa universitāte

Aadne Aasland, Ph. D., Oslo Metropolitēna universitāte

Literārā redaktore Gita Kḷavina

Vāka dizainu un maketu veidojusi Baiba Lazdiṇa

(C) Inese Šūpule, 2020

(C) Latvijas Universitāte, 2020

ISBN 978-9934-18-564-9 


\section{SATURS}

$\begin{array}{ll}\text { levads } & 5\end{array}$

1. Teorētiskās atziṇas par augsti kvalificētu speciālistu migrāciju un līdzšinējiem pētījumiem

2. Izglitiibas un darba trajektorijas.

Dzīves gaitas perspektīva

3. Adaptācijas stratēǵijas dzīvei ārvalstīs

4. Turpmākās mobilitātes plāni: atgriezties Latvijā vai ne?

106

5. Diskriminācijas uztvere augsti kvalificētu Latvijas sieviešu vidū emigrācijā

6. Politikas iespējas un izaicinājumi talantu piesaistīšanai Latvijai

Secinājumi

175

Literatūra un avoti

180

Summary 
SAĪSINĀJUMI

ASV - Amerikas Savienotās Valstis

CERN - Eiropas Kodolpētījumu organizācija

CV - Curriculum vitae (latv. - īss dzīves apraksts)

EBTA - Eiropas Brīvās tirdzniecības asociācija

EEZ - Eiropas Ekonomikas zona

EFTA - European Free Trade Association (latv. - Eiropas Brīvās tirdzniecības asociācija)

ES - Eiropas Savienība

ESF - Eiropas Sociālais fonds

ISCED - International Standard Classification of Education (latv. - Starptautiskā standartizētā izglītîbas klasifikācija)

IT - informācijas tehnologijas

LĀZA - Latviešu ārstu un zobārstu apvienība

LIAA - Latvijas Investīciju un attīstības aǵentūra

LTRK - Latvijas Tirdzniecības un rūpniecības kamera

NELM - the new economics of labour migration (latv. - darba migrācijas jaunā ekonomika)

NVS - Neatkarīgo Valstu Sadraudzība

OECD - Organisation for Economic Co-operation and Development (latv. - Ekonomiskās sadarbības un attīstības organizācija)

PBLA - Pasaules Brīvo latviešu apvienība

PLEIF - Pasaules latviešu ekonomikas un inovāciju forums

RSU - Rīgas Stradiṇa universitāte

RTU - Rīgas Tehniskā universitāte

STEM - Science, Technology, Engineering, and Mathematics (latv. - zinātne, tehnologiija, inženierzinātnes un matemātika)

VDR - Vācijas Demokrātiskā Republika 
Izglītotu un augsti kvalificētu migrantu skaita būtisks pieaugums pasaulē ir vērojams, sākot no 1990. gada (Lowell, 2007). Eiropas Savienībā (ES) augsti kvalificēto ES pilsoṇu pārvietošanās ES iekšienē laika posmā no 2004. gada līdz 2016. gadam ir gandrīz trīskāršojusies (ICF, 2018). Latvija kopā ar Lietuvu, Igauniju, Poliju, Slovākiju, Horvātiju, Portugāli un Rumāniju ir valsts, no kurienes iedzīvotāji aizplūst uz citām ES valstīm, un būtiska migrantu proporcija ir augsti kvalificētie migranti. Līdz ar to augsti kvalificēto speciālistu emigrācija šajās valstīs, arī Latvijā, kḷūst aizvien aktuālāka problēma. Vienlaikus līdz šim nepietiekama uzmanība ir pievērsta augsti kvalificētu Latvijas migrantu dzīves izpētei - trūkst zināšanu gan par viṇu adaptācijas pieredzi uzṇemošajās valstīs, gan par to, kā veidojas izglītības un darba gaitas Latvijas emigrantiem, kā arī par faktoriem, kas nosaka augsti kvalificēto emigrantu atgriešanos Latvijā. Kā augsti kvalificētie Latvijas emigranti pielieto Latvijā iegūtās zināšanas un prasmes? Kā viṇi pielāgojas jaunajām prasībām? Kādas politikas iniciatīvas var veicināt augsti kvalificēto Latvijas emigrantu atgriešanos? Šie ir jautājumi, kam veltīts pētījums 
"Latvijas augsti izglītotie emigranti: izglītības un darba pieredze Latvijā un ārvalstîs”.

Sākot no 20. gadsimta 60. gadu beigām, augsti kvalificētu speciālistu migrācija tiek apspriesta, izmantojot jēdzienu "smadzeṇu aizplūšana” (Adams, 1968; Fortney, 1970), taču pēdējos 20 gados dominē tādas paradigmas kā "globālā sacensība par talantiem” un “smadzeṇu cirkulācija” (Kuvik, 2012). Analizējot augsti kvalificēto speciālistu emigrāciju un atgriešanos Indijā vai Ķīnā, migrācijas optimisti jēdzienu "smadzen̨u aizplūšana” ir aizvietojuši ar jēdzieniem "smadzeṇu cirkulācija” vai pat "smadzeṇu ieguvumi” (Harvey, 2008; Saxenian, 2002, 2007). Tomēr nav pārāk daudz valstu, kas l̦oti priecātos par ieguvumiem no augsti kvalificētu speciālistu emigrācijas un vēlāk potenciālas atgriešanās. Daudzas zemu un vidēju ienākumu valstis saskaras ar augsti kvalificētu speciālistu trūkumu, īpaši veselības aprūpē, jo šie speciālisti ir aizbraukuši uz valstīm, kas piedāvā augstāku samaksu un labākas karjeras iespējas (Bailey \& Mulder, 2017). Lai mazinātu “smadzeņu aizplūšanas” negatīvo ietekmi uz izcelsmes valstīm, attīstītās Rietumvalstis izstrādā dažādas programmas. Tās iecerētas tā, lai sekmētu trīskāršu ieguvumu sasniegšanu, kur īstermiṇa ieguvēja būtu Rietumvalsts, bet arī migrants būtu apmierināts ar iespēju labi nopelnīt un tad atgriezties, bet izcelsmes valsts iegūtu no speciālista atgriešanās, kas ieguvis jaunu pieredzi un paaugstinājis kvalifikāciju Rietumos. Tomēr šãdas programmas var būt sekmīgas tikai tad, ja ir noteiktu apstākḷu kopums, kad, no vienas puses, indivīds ir ieinteresēts atgriezties izcelsmes valstī (mikrolīmenis), un, no otras puses, izcelsmes valsts var nodrošināt iespējas, tajā skaitā atbilstošu infrastruktūru, augsti kvalificētajam speciālistam izmantot iegūtās zināšanas un sekmēt savas valsts attīstību (makrolīmenis). Līdzšinējās Latvijas emigrantu atgriešanās tendences liecina, ka remigrācija pagaidām vēl nespēj kompensēt “smadzeṇu aizplūšanu” (Hazans, 2015).

Viens no būtiskākajiem Latvijas emigrācijas strukturālajiem aspektiem ir Eiropas Savienībā izveidotais unikālais "migrācijas režīms” (Favell, 2008; Engbersen \& Snel, 2013; Glorius, Grabowska-Lusinska, \& Kuvik, 2013), kas nosaka darbaspēka mobilitāti visās ES valstīs. Pievienošanās ES un tajā pastāvošajai brīvā darbaspēka kustībai būtiski mainīja mobilitātes iespējas Latvijai un citām jaunajām dalībvalstīm. Tas izmainīja arī centra un perifērijas attiecības ES (King et al., 2016a). Darba n̦ēmēju brīva pārvietošanās ir viens no Eiropas Savienības Līguma pamatprincipiem, kas nostiprināts Līguma par Eiropas Savienības darbību 45. pantā (2012). ES pilsoṇiem ir tiesības meklēt darbu citā ES valstī, strādāt tur bez darba aț̣aujas un uzturēties tur darba nolūkā, palikt tur pat pēc nodarbinātības beigām un baudīt vienādu attieksmi 
ar konkrētās valsts pilsoṇiem attiecībā uz nodarbinātības iespējām, darba apstākḷiem un visām citām sociālajām un nodokḷu priekšrocībām. 45. panta 2. punktā noteikts: pārvietošanās brīvība paredz, ka jebkāda dalībvalstu darba n̦ēmēju diskriminācija pilsonības dēḷ attiecībā uz nodarbinātību, darba samaksu un citiem darba un nodarbinātības nosacījumiem nav piel̦aujama. Darba ñēmēju brīva pārvietošanās attiecas arī uz Islandi, Lihtenšteinu un Norvēǵiju, kas ietilpst Eiropas Ekonomikas zonā (EEZ).

Apzinoties šo makrolīmeņa struktūru ietekmi, kas sekmē migrāciju no Latvijas, pētījuma centrā ir augsti kvalificēto Latvijas emigrantu individuālās pieredzes jeb migrācijas procesu mikrolīmenis. Turpinājumā raksturotas augsti kvalificēto Latvijas emigrantu migrācijas plūsmas ES kontekstā un salīdzinājumā ar Igauniju un Lietuvu.

\section{LATVIJAS EMIGRANTU MIGRĀCIJAS STATISTIKA}

Salīdzinošu statistiku par augsti izglītotu ES valstu pilsoṇu migrāciju piedāvā Eiropas Savienības darbaspēka apsekojums (European Union Labour Force Survey - EU LFS), kas tiek veikts 28 Eiropas Savienības dalībvalstīs un trīs Eiropas Brīvās tirdzniecības asociācijas (EBTA; tās locekles ir Norvēǵija, Šveice, Islande, Lihtenšteina) valstīs saskaṇā ar Padomes Regulu (EEK) Nr. 577/98 (1998. gada 9. marts). Tas ir plašs mājsaimniecību izlases veida apsekojums, kas sniedz informāciju par personām virs 15 gadu vecuma. Latvijā darbaspēka izlases apsekojumu veic Centrālā statistikas pārvalde. Saskaņā ar pieejamajiem datiem 2018. gadā 11,8\% jeb 149000 Latvijas pilsoṇu darbspējas vecumā no 20 līdz 64 gadiem dzīvoja kādā no ES/EBTA valstīm ārpus Latvijas (Eurostat, 2019). 2008. gadā tikai 4\% Latvijas pilsoṇu vecumā no 20 līdz 64 gadiem dzīvoja kādā no ES valstīm ārpus Latvijas. Salīdzinājumam vislielākais pilsoṇu skaits, kas 2018. gadā dzīvoja ES ārpus savas valsts, ir Rumānijā (21,3\%), Horvātijā (15,4\%), Lietuvā (14,5\%), Portugālē (13,6\%), Bulgārijā (13,3\%). Latvija ierindojas sestajā vietā aiz Bulgārijas. Vismazākais pilsoṇu skaits, kas 2018. gadā dzīvoja ES ārpus savas valsts, ir Vācijā (1,0\%) un Lielbritānijā (1,1\%) (1. attēls).

No visiem Latvijas pilsoṇiem vecumā no 20 līdz 64 gadiem, kas 2018. gadā dzīvoja kādā no ES valstīm ārpus Latvijas, 31,0\% bija augstākā izglītîba (ISCED 5-8). 2008. gadā šī proporcija bija 17,1\%. Saskaņā ar Eurostat statistisku augsti izglītoto pilsoṇu īpatsvars, kas dzīvo ārpus Latvijas, ir līdzīgs to augsti izglītoto pilsoṇu īpatsvaram, kuri dzīvo Latvijā (32,3\%). Kopumā var 


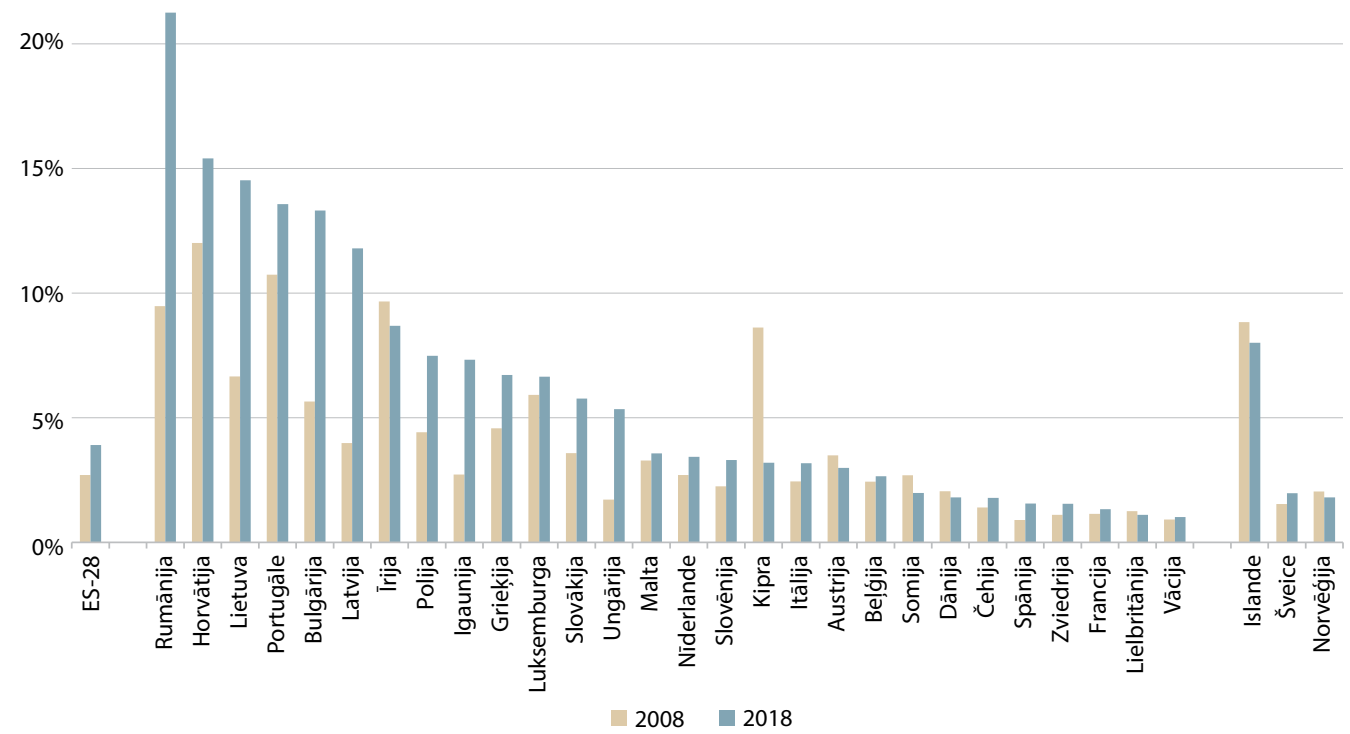

1. attēls. Darbspējas vecuma (20-64 g. v.) ES pilsoṇu mobilitāte pēc pilsoniskās piederības, $\%$ no izcelsmes valsts iedzīvotāju skaita

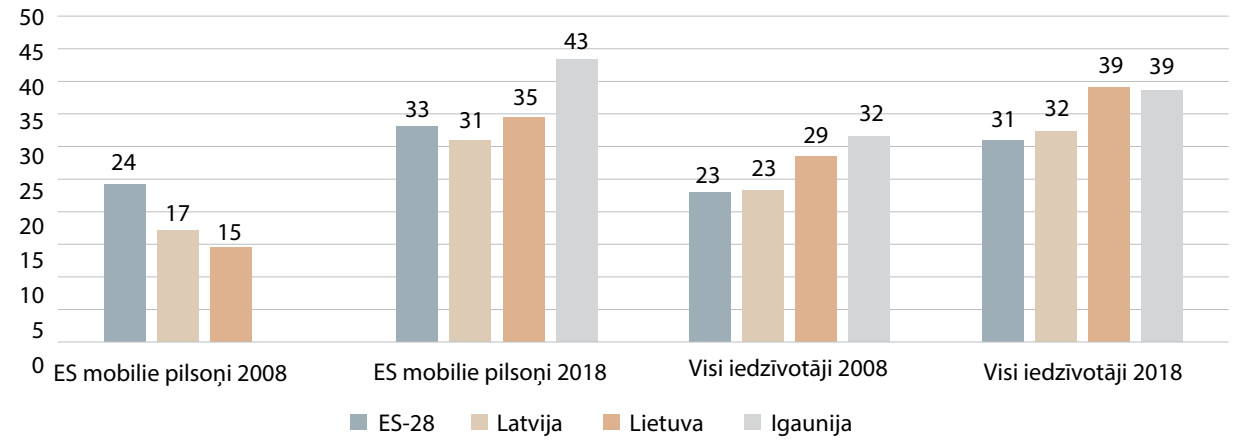

\section{2. attēls. Darbspējas vecuma (20-64 g. v.) ES mobilie pilsoṇi ar augstāko izglītību} (ISCED 5-8) pēc pilsonības, \%

Avots: Eurostat, 2019.

ES mobilie pilsoṇi ir ES valstu piederīgie, kas dzīvo ārpus tās ES valsts, kuras pilsoṇi viṇi ir. Pirmais stabinš̌ no kreisās parāda, ka 2008. gadā 24,2\% ES 28 valstu pilsoṇu, kas dzīvoja ES ārpus tās ES valsts, kuras pilsoṇi viṇi ir, bija augstākā izglîtība (ISCED 5-8). 
secināt, ka augsti izglītoto Latvijas emigrantu īpatsvars citās ES/EFTA valstīs desmit gadu laikā ir būtiski pieaudzis (2. attēls).

Saskaṇā ar pieejamo oficiālo statistiku Latvijas emigrantiem ES/EFTA valstīs raksturīgs augstāks nodarbinātības līmenis (82,8\%) nekā pilsoṇiem Latvijā (76,8\%), un tas liecina, ka Latvijas emigranti lielākoties ir darba migranti (Eurostat, 2019). Augsti izglītoto pilsoṇu vidū nodarbinātība ir augstāka gan Latvijā, gan ārvalstīs, bet Latvijā augsti nodarbināto vidū tā ir nedaudz augstāka (88,9\%) nekā ārvalstīs (83,8\%). Minētā statistika attiecas uz tām ES/EEZ valstīm, uz kurām kopumā novērojamas lielākās migrācijas plūsmas (3. attēls).

Mihails Hazans (2019) savā izpētē par emigrācijas tendencēm no Latvijas 21. gadsimta pirmajos 16 gados norāda uz četriem migrācijas posmiem. Pirmais posms (2000-2003) ir pirms Latvijas pievienošanās ES, kad emigrācija ir salīdzinoši zemā līmenī. Otrais posms (2004-2008) saistās ar Latvijas pievienošanos ES un ar ES valstu darba tirgus pakāpenisku atvēršanos emigrantiem no Latvijas, kas sekmēja emigrācijas apjomu trīskāršošanos (Hazans, 2019: 44). Trešajam posmam (2009-2010) raksturīgs straujš emigrācijas pieaugums, ko izsauca ekonomiskā krīze un tās sekas Latvijā. Savukārt ceturto posmu (2011-2016) M. Hazans raksturo kā pēckrīzes migrācijas vilni.

Sākot no 2013. gada, ir pieejami Centrālās statistikas pārvaldes apkopotie dati par remigrantu īpatsvaru imigrantu vidū (1. tabula). Pieejamie dati liecina, ka remigrantu īpatsvars visaugstākais bija 2013. gadā (68\%), bet laikā līdz 2018. gadam tas samazinājās līdz 44\% no visiem imigrantiem. 2019. gadā

1. tabula. Remigrantu îpatsvars un raksturojums

\begin{tabular}{lccccccc}
\hline & $\mathbf{2 0 1 3}$ & $\mathbf{2 0 1 4}$ & $\mathbf{2 0 1 5}$ & $\mathbf{2 0 1 6}$ & $\mathbf{2 0 1 7}$ & $\mathbf{2 0 1 8}$ & $\mathbf{2 0 1 9}$ \\
\hline Imigrācija pavisam & 8299 & 10365 & 9479 & 8345 & 9916 & 10909 & 11223 \\
\hline No tiem remigranti & 5648 & 6762 & 5617 & 5409 & 5455 & 4852 & 5114 \\
\hline Remigranti Latvijas pilsoṇi & 4774 & 5864 & 4974 & 4897 & 4780 & 4346 & 4578 \\
\hline $\begin{array}{l}\text { Remigranti Latvijas } \\
\text { nepilsoṇi }\end{array}$ & 617 & 719 & 482 & 379 & 525 & 367 & 327 \\
$\begin{array}{l}\text { Remigranti, kas dzimuši } \\
\begin{array}{l}\text { Latvijā (nav Latvijas pilsoṇi } \\
\text { un Latvijas nepilsoṇi) }\end{array}\end{array}$ & 257 & 179 & 161 & 133 & 150 & 139 & 142 \\
$\begin{array}{l}\text { Remigrantu ipatsvars (\%) no } \\
\text { visiem imigrantiem }\end{array}$ & 68,06 & 65,24 & 59,26 & 64,82 & 55,01 & 44,48 & 45,57 \\
\hline
\end{tabular}

Avots: CSP, 2020c. 


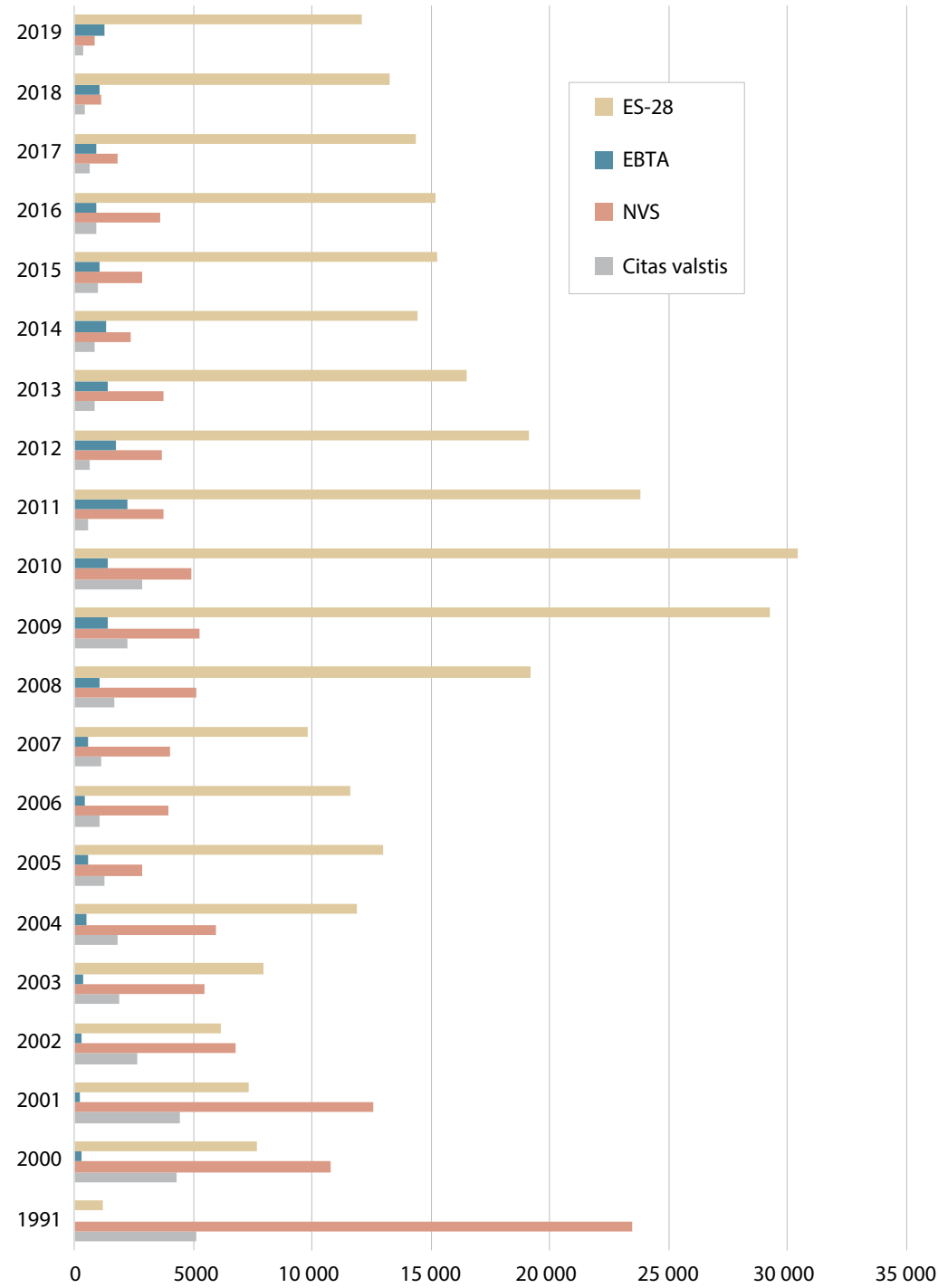

\section{3. attēls. Starptautiskā ilgtermiṇa migrācija pa valstu grupām, skaits}

Avots: CSP, 2020a.

EBTA locekles ir Norvēǵija, Šveice, Islande, Lihtenšteina.

Neatkarīgo Valstu Sadraudzības (NVS) valstis ir Armēnija, Azerbaidžāna, Baltkrievija, Gruzija (no 2009. gada septembra vairs neietilpst NVS), Kazahstāna, Kirgizstāna, Krievija, Moldovas Republika, Tadžikistāna, Turkmenistāna (asociētā dalībnieka statusā), Ukraina (asociētā dalïbnieka statusā), Uzbekistāna. 
no 11223 imigrantiem 46\% jeb 5114 personas bija remigranti. No tiem 90\% ir Latvijas pilsoṇi, bet 6\% Latvijas nepilsoṇi. Lielākais remigrantu īpatsvars ir Rīgas un Pierīgas reǵionā (kopā 47\%). 2019. gadā 42\% remigrantu bija vecumā no 25 līdz 44 gadiem. 58\% no visiem remigrantiem 2019. gadā bija vīrieši. Diemžēl pieejamā statistika nesniedz informāciju par izglītības un nodarbinātības līmeni remigrantu vidū.

\section{PĒTNIECISKIE JAUTĀJUMI UN DATU IEGUVES METODES}

Jēdziens "augsti kvalificēto migrācija” šajā pētījumā attiecas uz ilgtermiņa starptautisko migrāciju to pilsoṇu vidū, kas ieguvuši augstāko izglītību (ISCED 6-8, kas atbilst bakalaura, maǵistra vai doktora grādam). Tātad šajā pētījumā universitātes izglītīiba ir pielīdzināta augstas kvalifikācijas iegūšanai. Šāda izvēle ir balstīta uz praktiskiem apsvērumiem, jo izglītības līmenis ir statistikas un aptaujas datos pieejams rādītājs. Pētījums ir veikts socioloǵijas nozarē, bet gan teorētiskajā izpētē, gan empīriskajā analīzē daudzas atziṇas un ierosme ir gūtas no citām zinātnuu nozarēm (ekonomikas, politikas zinātnes, geogrāfijas, demogrāfijas un antropoloǵijas). Piemēram, tādas ekonomikas teorijas kā neoklasiskā ekonomikas teorija un darba migrācijas jaunā ekonomika ir būtiskas, pētot faktorus, kuri ietekmē augsti kvalificēto emigrantu atgriešanos Latvijā. Šo iemeslu dēḷ pētījumā uzsvērta starpdisciplinaritāte, kas ir būtiska visos migrācijas pētījumos.

Izmantojot gan kvantitatīvās, gan kvalitatīvās informācijas iegūšanas metodes, monogrāfijā ir meklētas atbildes uz četriem pētnieciskajiem jautājumiem: (1) Kā augsti kvalificēti Latvijas emigranti pielāgojas situācijai un darba tirgus prasībām uzṇemošajā valstī? (2) Kas ir tie augsti kvalificētie Latvijas emigranti, kas apsver iespēju atgriezties Latvijā, un kādi faktori nosaka augsti kvalificēto emigrantu atgriešanos Latvijā? (3) Kā augsti kvalificētas Latvijas emigrantes vērtē savu emigrācijas pieredzi, un kādi faktori palielina uztverto diskrimināciju darbavietā? (4) Kādas politikas iniciatīvas var veicināt augsti kvalificēto Latvijas emigrantu atgriešanos?

Pētījumā izmantoti gan aptauju, gan padziḷināto interviju dati. Galvenie analīzē izmantotie kvantitatīvo aptauju dati ir: (1) projektā "Latvijas emigrantu kopienas: nacionālā identitāte, transnacionālās attiecības un diasporas politika” veiktā emigrantu aptauja; (2) emigrantu aptaujas otrais vilnis un remigrantu aptauja, kas organizēta projektā "Labklājības un sociālās integrācijas izpēte likvīdās migrācijas kontekstā: longitudinālā pieeja”. 
Projektā "Latvijas emigrantu kopienas: nacionālā identitāte, transnacionālās attiecības un diasporas politika” veiktā emigrantu aptauja tika organizēta laikā no 2014. gada 4. augusta līdz 30. oktobrim. Aptaujā tika iegūtas 14068 Latvijas emigrantu atbildes no 118 valstīm, un tā ir apjomīgākā vienas valsts emigrantu aptauja, kāda jebkad veikta Eiropā. Tas ir ḷoti nozīmīgi, jo l̦auj veidot specifiskas apakšizlases noteiktām grupām, šajā gadījumā - augsti izglītotiem Latvijas pirmās paaudzes emigrantiem. Vislielākais skaits aptaujas dalībnieku dzīvo Lielbritānijā, Vācijā, Īrijā, Norvēǵijā, ASV, Zviedrijā, taču aptaujā piedalījās diasporas pārstāvji arī no tik tālām un eksotiskām valstīm kā Japāna, Meksika, Saūda Arābija un Zimbabve. Vairums respondentu ir jaunās diasporas pārstāvji, kuri atstāja Latviju pēc 1991. gada, taču 6,5\% pārstāv t. s. veco diasporu jeb trimdas latviešus, tai skaitā otrās paaudzes ārzemēs dzīvojošos latviešus. N̦emot vērā šī pētījuma mērḳus, analīzē tika iekḷauti tikai pirmās paaudzes emigranti no Latvijas, kuri emigrējuši pēc 1990. gada. Kvantitatīvo datu iegūšanai izmantota interneta aptauja, un datu analīzē un interpretācijā ir jāṇem vērā šîs metodes ierobežojumi, kas galvenokārt saistīti ar aptaujas izlases reprezentativitāti. Lai sasniegtu pēc iespējas lielāku un daudzveidīgāku Latvijas emigrantu izlasi, respondentu rekrutācijai tika izmantoti sociālo tīklu portāli Facebook, draugiem.lv, Vkontakte, Odnoklassniki, latviesi.com; lielākie Latvijas ziṇu portāli: Delfi, Tvnet, Apollo, Inbox; vēstniecības, diasporas organizācijas, diasporas mediji, diasporas interešu grupas, draudzes, latviešu skolas u. c. Pētnieki sagatavoja informācijas izplatīšanas kanālu sarakstu, kas ietvēra 187 dažādas diasporas organizācijas un asociācijas, latviešu kultūras centrus, draudzes un citas organizācijas, kas ir populāras Latvijas diasporas vidū. İpaša uzmanība tika pievērsta tam, lai būtu pārstāvēti gan latviešu, gan krievu vidū populāri portāli. Pētnieku izstrādātā anketa tika testēta, izmantojot kognitīvās intervijas (10 intervijas) un tiešsaistes testēšanas (angl. - web-probing) tehniku (23 testi), kas piemērota pētījumiem internetā (vairāk par aptaujas aprakstu skat. Mieriņa \& Koroḷeva, 2015).

Interneta aptauju izmantošana socioloǵiskos pētījumos joprojām tiek uztverta piesardzīgi, tomēr vairāki ievērojami autori uzsver, ka tā ir piemērota izlases metode, veidojot ǵgogrāfiski ḷoti izkaisītu un lielu izlasi ierobežotā laikā (Sue \& Ritter, 2012; McGhee, Moreh, \& Vlachantoni, 2017; McCollum et al., 2017). Vienlaikus interneta aptaujas metodei ir noteikti ierobežojumi, jo tā ir pašizlases aptaujas metode. Pašizlase piemīt jebkurai aptaujai, kur potenciālais respondents var atteikties piedalīties pētījumā, bet šajā gadījumā potenciālajam respondentam ir jābūt ieinteresētam Latvijas emigrantu un diasporas jautājumos, lai viņš vispār sāktu aizpildīt aptaujas anketu. 
Lielākajā dạ̦ā gadījumu, kur analīzē izmantoti šīs aptaujas dati, tie attiecas uz apakšizlasi attiecībā uz augsti izglītotiem un strādājošiem Latvijas pirmās paaudzes emigrantiem. Tomēr vairākās nodaḷās veidotas vēl papildu apakšizlases, piemēram, augsti izglītoti un strādājoši Latvijas pirmās paaudzes emigranti ES valstīs vai augsti izglītotas un strādājošas Latvijas pirmās paaudzes emigrantes - sievietes. Analīzē izmantoti nesvērti aptaujas dati.

Emigrantu aptaujas otrais vilnis un remigrantu aptauja, kas organizēta projektā "Labklājības un sociālās integrācijas izpēte likvīdās migrācijas kontekstā: longitudinālā pieeja”, notika laikā no 2019. gada 24. septembra līdz 11. novembrim. Aptaujā piedalījās vairāk nekā 4000 latviešu un Latvijas valstspiederīgo, kas dzīvo ārpus Latvijas, un vairāk nekā 2000 remigrantu, kas atgriezušies Latvijā. Aptaujas metodologiija lielā mērā pārklājas ar aptaujas pirmo vilni. Visaktīvāk aptaujā piedalījās Lielbritānijā dzīvojošie Latvijas emigranti (ap 25\%), un aktīvi savu viedokli pauda arī Vācijā, ASV, İrijā un Ziemeḷvalstīs dzīvojošie. Līdzīgi kā pirmajā vilnī, arī šajā aptaujā lielāku atsaucību izrādīja sievietes, kā arī latvieši. Analīzes nolūkiem izveidotā apakšizlase aptver augsti kvalificētus Latvijas izcelsmes speciālistus viedās specializācijas jomās. Apakšizlases kopējais respondentu skaits ir 792 respondenti, no kuriem 653 atrodas emigrācijā, bet 139 pēc emigrācijā pavadītajiem gadiem ir atgriezušies Latvijā. Arī šîs aptaujas analīzē izmantoti nesvērti aptaujas dati.

Kvalitatīvās izpētes dati ir iegūti, veicot 50 padziḷinātās intervijas ar augsti kvalificētiem Latvijas emigrantiem un remigrantiem no ASV, Lielbritānijas, Zviedrijas, Norvēgijas un Vācijas (katrā valstī 10 intervijas). Lai noskaidrotu, kāda ir migrācijas pieredze augsti kvalificētiem migrantiem no Latvijas, kā arī to, kā viṇi šo pieredzi interpretē plašākā sociālā kontekstā, pētījumā tika izmantota naratīvās intervijas metode ar dạ̣ēji strukturētas padziḷinātās intervijas elementiem. Tas nozīmē, ka, aicinot raksturot savu migrācijas pieredzi, informantiem jautājums tika veidots tādā formā, kas sekmē sava migrācijas stāsta formulēšanu, apkopojot ar migrāciju saistītos notikumus. Piemēram, intervijās tika uzdoti jautājumi: "Pastāstiet, lūdzu, par savu lēmumu doties uz Lielbritāniju? Kādēḷ jūs nolēmāt aizbraukt no Latvijas?” Cits piemērs ir saistīts ar jautājumu par darba pieredzi ārvalstīs: "Vai jūs varat pastāstīt par savu pirmo darba vietu Norvēǵijā? Kā jūs to atradāt? Kā jūs jutāties, sākot strādāt Norvēǵijā?” Šie jautājumi ievada sarunu, kurā informants brīvā formā stāsta par savu dzīves pieredzi, un papildu jautājumi var tikt uzdoti, lai precizētu kādu stāstījuma aspektu. Lai noskaidrotu faktologisko informāciju, intervijā iekḷauti arī dạ̣̄eji strukturēti jautājumi. Dažas no 50 intervijām neizvērsās kā 
naratīvās intervijas, jo informants nevēlējās formulēt savu pieredzi garā stāstījumā. Šajos gadījumos notika daḹeji strukturēta padziḷinātā intervija, kurā, detalizēti izjautājot, noskaidrota informanta pieredze par galvenajām pētījuma tēmām (izglìtības un darba trajektorijas, migrācijas lēmumu pieṇemšana, adaptācija uzṇemošajā valstī, saišu saglabāšana ar Latviju). Padziḷinātās intervijas veiktas laikā no 2018. gada novembrim līdz 2019. gada jūnijam.

Datu analīzes stratēǵijas ir pakārtotas katram konkrētajam pētnieciskajam jautājumam, un analīzes nodaḷu sākumā konkrētā pieeja ir izvērsti paskaidrota. Galvenās izmantotās kvantitatīvo datu analīzes metodes ir faktoru analīze un binārā loǵistiskās regresijas analīze. Augsti kvalificēto Latvijas emigrantu karjeras trajektoriju izpratnei un adaptācijas stratēǵiju raksturošanai izmantota naratīvo interviju dokumentārās interpretācijas metode (angl. the documentary interpretation of narrative interviews) (Nohl et al., 2006). Šī pieeja ļauj gan rekonstruēt noteiktus dzīvesstāsta aspektus, ko darba migrācijas kontekstā izcēlis informants, gan arī atklāt adaptācijas un mācīšanās procesu uzṇemošajā valstī.

Monogrāfiju veido ievads, sešas nodaḷas un secinājumi. Pirmā nodaḷa ir veltīta monogrāfijas teorētiskā konteksta izpratnei un sniedz ieskatu galvenajos migrācijas procesos, jēdzienos un teorijās saistībā ar augsti kvalificēto personu migrāciju un remigrāciju. Tajā apskatīts migrācijas lēmuma pieņemšanas process un migrācijas ietekme dažādos līmen,os. Balstoties uz iepriekš veiktajiem pētījumiem un migrācijas teorijām, izveidots migrācijas analīzes rāmis makrolīmenī, mezolīmenī un mikrolīmenī. Mikrolīmenī, kurā indivīds pieṇem migrācijas lēmumu, izvērtēti potenciālie migrācijas riski un iespējas, kā arī ņemti vērā ǵimenes un draugu attieksmes un rīcības modeḷi. Indivīdu situāciju ietekmē plašāks sociālais konteksts, piemēram, noteikti ekonomiskās attīstības cikli, valstu migrācijas politikas un sabiedrībā dominējošās vērtības un attieksmes pret migrāciju. Dažādi sociālie tīkli, darba kolēǵu, paziṇu un draugu loks arī var sekmēt vai tieši otrādi - kavēt migrācijas lēmuma pieṇemšanu. Arī tāds fenomens kā relatīvā deprivācija valstīs ar augstu ienākumu nevienlīdzību, kā Latvijā, var sekmēt migrācijas lēmuma pieṇemšanu. Saskaṇā ar relatīvās deprivācijas teoriju (Runciman, 1966) relatīvā deprivācija attiecas uz gadījumiem, kad persona uzskata, ka dzīvo sliktāk, nekā tai būtu jādzīvo salīdzinājumā ar citiem savā grupā vai ar sevi pagātnē vai nākotnē. Objektīvi 
konkrētajai personai var būt salīdzinoši augsti ienākumi, bet sajūtu līmenī tā var būt neapmierināta. Makrolīmenī nozīmīga ir arī uzṇemošās valsts darba tirgus situācija un migrācijas politika. No socioloǵijas teorijām īpaša uzmanība pievērsta Burdjē kultūras kapitāla teorijai un tās pielietojumam migrācijas pētījumos, kā arī pieejām, kas saistītas ar sociālo tīklu teorijām un migrāciju.

Otrajā nodạ̄ā ir pētītas augsti kvalificēto Latvijas emigrantu izglītības un darba trajektorijas. Tajā analizēti 17 dzīvesstāsti piecās dažādās valstīs, raksturojot gan emigrantu, gan remigrantu izglītības, darba un būtiskākajos aspektos arī privātās dzīves trajektorijas. Uzmanības centrā šajos stāstos ir dažādi ar migrāciju vai karjeru saistīti pagrieziena vai lūzuma punkti, kas raksturo emigranta statusa maiṇu konkrētajā dzīves situācijā. Augsti kvalificētu speciālistu migrācijas šajā analīzē aplūkotas kā daudzdimensionāla statusa maiṇa (Nohl et al., 2006) - tas nozīmēe, ka migrācija ne tikai ir saistīta ar statusa maiṇu indivīda karjerā, bet arī ietekmē partnerattiecības, ǵimeni un plašākas sociālās saites. Analīzē izmantota naratīvo interviju dokumentārās interpretācijas metode, kas ḷauj gan rekonstruēt noteiktus dzīvesstāsta aspektus, ko darba migrācijas kontekstā izcēlis informants, gan arī atklāt adaptācijas un mācīšanās procesu uzṇemošajā valstī. Izmantojot šo analīzes pieeju, veikta katra konkrētā dzīvesstāsta rekonstrukcija saistībā ar izglītības un darba trajektorijām. Tās apkopotas arī ilustratīvā shēmā, kas sniedz priekšstatu par migrācijas ietekmi uz karjeras veidošanu katrā konkrētā dzīvesstāstā.

Trešajā nodạ̣ā analizēts, kādas adaptācijas stratēǵijas izmanto augsti kvalificētie Latvijas emigranti, lai labāk iekḷautos uzṇemošajā valstī. Šī nodạ̧a sniedz atbildes uz pētniecisko jautājumu: kā augsti kvalificēti Latvijas emigranti pielāgojas situācijai un darba tirgus prasībām uzṇemošajā valstī? Ir analizēti šḳēršḷi un grūtības, ar ko tie sastopas, kā arī tas, kā augsti kvalificētie Latvijas emigranti izmanto Latvijā iegūtās prasmes un zināšanas. Lai gan salīdzinājumā ar citām emigrantu grupām augsti kvalificētiem emigrantiem ir savas priekšrocības, arī viṇi sastopas ar uzṇemošajā sabiedrībā pastāvošo sociālo struktūru, ar tās noteiktajām privilēgijām kādām grupām un izjūt grūtības tajā integrēties (Bailey \& Mulder, 2017). Augsti kvalificētiem migrantiem ir jāiemācās sevi pasniegt jaunajā darbavietā tā, lai viṇu kvalifikācija tiktu novērtēta, bet sākuma posmā tam dažkārt trūkst valodas prasmju un zināšanu par pieṇemtajiem uzvedības modeḷiem (Csedö, 2008; Koikkalainen, 2013).

Ceturtā nodaḷa sniedz atbildi uz otro pētniecības jautājumu: kas ir tie augsti kvalificētie Latvijas emigranti, kas apsver iespēju atgriezties Latvijā, un kādi faktori nosaka augsti kvalificēto emigrantu atgriešanos Latvijā? Balstoties uz kvantitatīvo datu analīzi, šajā nodaḷā izvērtēta trīs faktoru grupu ietekme uz 
augsti kvalificēto emigrantu plāniem atgriezties Latvijā: (1) sociāldemogrāfiskie rādītāji; (2) emigrācijas motivācija un apmierinātība ar dz̄vi ārzemēs; (3) piederības sajūta uzṇemošajai valstij un Latvijai. Analīzēe izmantota binārā logiistiskās regresijas analīze.

Piektā nodaḷa ir veltīta augsti kvalificēto sieviešu migrācijas pieredzes izpētei un analizē darba diskriminācijas subjektīvo uztveri. Tās galvenais uzdevums ir atbildēt uz trešo pētniecisko jautājumu: cik lielā mērā augsti kvalificētas Latvijas emigrantes saskaras ar diskrimināciju darbavietā, un kādi faktori palielina uztvertās diskriminācijas varbūtību? Dažādu faktoru ietekmes noteikšanai izmantota binārā loğistiskās regresijas analīze.

Sestā nodaḷa sniedz ieskatu dažādu valstu politikās un iniciatīvās, kas vērstas uz augsti kvalificētu emigrantu atgriešanu izcelsmes valstī un "smadzeņu aizplūdes” negatīvās ietekmes mazināšanu. Nodaḷas uzdevums ir atbildēt uz ceturto pētniecisko jautājumu: kādas politikas iniciatīvas var veicināt augsti kvalificēto Latvijas emigrantu atgriešanos?

Monogrāfijas noslēgumā secinājumos izceltas galvenās atziṇas, kas iegūtas šajā pētījumā, un diskutēts par iespējām šīs atziṇas vispārināt, norādot arī uz pētījuma ierobežojumiem. Tas savukārt ḷauj reflektēt par turpmākajiem pētījumiem, kas sniegtu jaunas zināšanas par augsti kvalificēto speciālistu migrācijas fenomenu. 

SPECIĀLISTU MIGRĀCIJU UN LITDZŠINĒJIEM PĒTIJJUMIEM

Sociālo zinātṇu literatūrā nepastāv vienota vispārpieņemta definīcija, ko nozīmē jēdziens “augsti kvalificēts migrants” (angl. - highly skilled migrant). N̦emot vērā to, ka dažādas valstis īsteno atšḳirīgu politiku attiecībā uz augsti kvalificētu speciālistu piesaistīšanu no citām valstīm, definīcijas katrā gadījumā ir atšḳirīgas. Visplašākā definīcija noteic, ka augsti kvalificēti migranti ir visi tie, kam ir migrācijas pieredze un augstākā izglītība, tomēr l̦oti daudzas definīcijas iekḷauj arī precizējumus par migrācijas virzienu un ilgumu un paredz konkrētas kvalifikācijas vai profesijas. Tāpat augsti kvalificētu speciālistu migrācijas jēedziena izpratne lielākoties neiekḷauj tādus gadījumus, kad personas ar augstāko izglītību jaunajā mītnes zemē veic mazkvalificētus darbus. Vienlaikus tas nozīmē, ka statistikas uzskaite par izglītības līmeni nepilnīgi raksturo augsti kvalificētu speciālistu migrācijas procesus šajā jēdzieniskajā nozīmē.

Augsti kvalificētu migrantu pētniecībai līdz nesenam laikam tika pievērsta mazāka uzmanība, jo tā tika uztverta nevis kā pastāvīga pārcelšanās dzīvot uz 


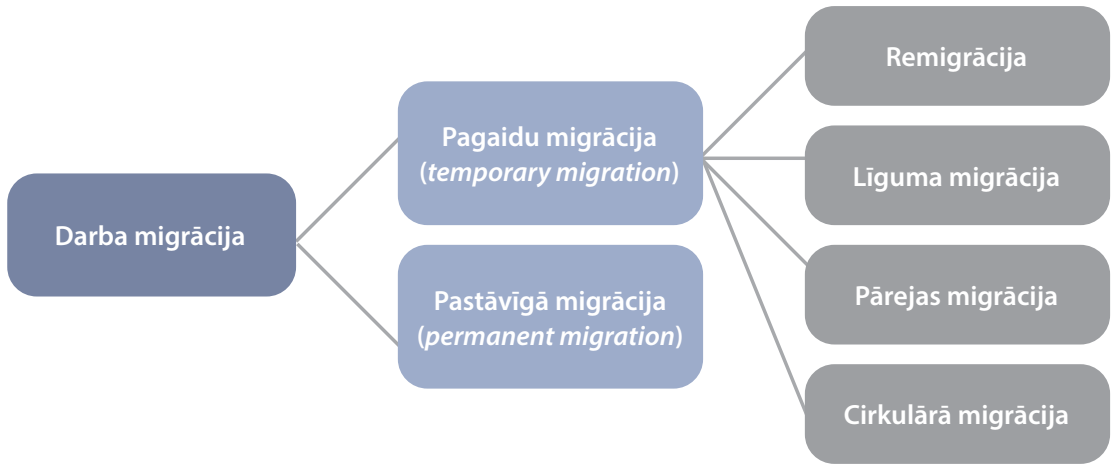

1.1. attēls. Darba migrācijas veidi

Avots: modificēts, balstoties uz K. Dastmena klasifikāciju (Dustmann, 2000).

kādu valsti, bet gan kā terminēta pārcelšanās uz projekta laiku. Tomēr pēdējo 20 gadu tendences liecina, ka arī augsti kvalificēti migranti mēdz pārcelties uz citām valstīm pastāvīgi vai arī pārvietojas no vienas valsts uz citu un dzīvo transnacionālu dzīvesveidu. Saskaṇā ar Kristjana Dastmena (Christian Dustmann) klasifikāciju (Dustmann, 2000) var noškirt vairākus pagaidu migrācijas veidus (1.1. attēls). Remigrācija (angl. - return migration) ir situācija, kad migrants atgriežas savā izcelsmes valstī pēc paša izvēles, dažkārt pēc ilgāka perioda ārzemēs. Līguma migrācija (angl. - contract migration) ir pagaidu migrācija, kad dzīvi un darbu ārzemēs nosaka līguma nosacījumi. Pārejas migrācija (angl. transient migration) raksturo situāciju, kad persona migrē no vienas valsts uz citu, neatgriežoties izcelsmes valstī, savukārt cirkulārā migrācija (angl. circular migration) ir atkārtota migrēšana no izcelsmes valsts uz uzṇemošo valsti. Robežas starp šiem migrācijas veidiem ir samērā izplūdušas, jo, piemēram, cirkulārā migrācija var būt arī līguma migrācija (bet var arī nebūt). Joprojām dominējošā tendence ir tā, ka migrācija biežāk ir uzskatāma par pagaidu migrāciju, jo migranti, īpaši augsti kvalificēti speciālisti, ir aktīvi un fleksibli un bieži vien ir gatavi izskatît jaunus darba piedāvājumus un pārcelties uz citu valsti.

Rasels Kings (Russell King) arī nodala vairākus remigrācijas tipus: gadījuma rakstura atgriešanās, sezonāla atgriešanās, pagaidu atgriešanās, pastāvīga atgriešanās un cirkulāra atgriešanās. Visbiežāk sastopamie atgriešanās iemesli ir pensionēšanās, grūtības adaptēties uzṇemošajā valstī, neveiksmes emigrācijā, plānoto ienākumu iegūšana, plāns uzsākt savu uzṇēmējdarbību izcelsmes valstī (King, 2000). 
Andress Solimano (Andrés Solimano) ar citiem vadošiem ekspertiem (Solimano, 2008), analizējot augsti kvalificētu speciālistu migrācijas procesus, izvēlas augsti kvalificētos migrantus definēt kā "talantus” un piedāvā šādu klasifikāciju:

1) tehniskie talanti;

2) zinātnieki un starptautiskie studenti;

3) profesionāḷi veselības aprūpes jomā (ārsti un medmāsas);

4) uzṇēmēji;

5) vadītāji un profesionāḷi starptautiskās organizācijās;

6) kultūras talanti.

Ar tehniskajiem talantiem A. Solimano apzīmē ekspertus informācijas tehnoloǵiju (IT) jomā, telekomunikācijās un datorzinībās, un daudzās valstīs šiem speciālistiem ir atviegloti iebraukšanas un uzturēšanās nosacījumi. Tiek uzskatīts, ka vislielākais īpatsvars šīs jomas augsti kvalificēto migrantu ir no Indijas (Solimano, 2008: 23).

Zinātnieki un starptautiskie studenti ir otra talantu grupa, un tajā tiek iekḷauti gan dabaszinātṇu un matemātikas, gan sociālo zinātṇu speciālisti ar augstu kvalifikāciju, starptautiskām publikācijām un kontaktiem. Viens no instrumentiem, kā piesaistīt jaunos zinātniekus, ir maǵistrantūras vai doktorantūras studijas ārvalstīs, kā arī pēcdoktorantūras atbalsta programmas. Saskaṇā ar Ričarda Frīmena (Richard Freeman) novērtējumu (Freeman, 2006) 2004. gadā starptautisko studentu skaits pasaulē bija apmēram divi miljoni, un vairāk nekā ceturtā daḷa starptautisko studentu mācījās ASV universitātēs. Skaitliski vislielākais starptautisko studentu īpatsvars ir no Indijas un Ķīnas. Lai gan daḷa studentu atgriežas savās izcelsmes valstīs, tomēr dą̣a studentu paliek un turpina profesionālo karjeru valstīs vai reǵionos, kur mācījušies. Līdz ar to starptautisko studentu migrācija veicina gan tādus procesus kā "smadzeṇu aizplūšana” (angl. - brain drain), gan arī "smadzeṇu cirkulāciju” (angl. - brain circulation).

Īpaša augsti kvalificētu migrantu grupa ir profesionālii veselības aprūpes jomā (ārsti un medmāsas), kuru aizbraukšana daudzās migrantu izcelsmes valstīs, tai skaitā arī Latvijā, rada grūtības nodrošināt veselības aprūpes pakalpojumus. Neskatoties uz to, ka veselības aprūpes jomā ir pietiekami sarežgî̀ta licencēšanas procedūra, kas ierobežo migrāciju, daudzi veselības aprūpes speciālisti no mazāk attīstītām valstīm uzsāk komplicēto procesu, lai iekḷūtu citu valstu darba tirgū un saņemtu ievērojami augstāku atalgojumu.

Cita specifiska augsti kvalificēto migrantu grupa ir uzṇēmēji, kuru migrācija rada tiešus zaudējumus izcelsmes valstij, savukārt atgriešanās var nest 
būtisku pienesumu kapitāla, tehnologiju un starptautisko kontaktu veicināšanā izcelsmes valstī. Vienlaikus jānorāda, ka ne visi uzṇēmēji sekmē starptautisko uzṇēmumu attīstību, ir arī ḷoti nelieli uzṇēmēji, kas bieži strādā ǵimenes biznesā. Spilgtākie piemēri tam ir etniskās virtuves restorāni (ḳīniešu, indiešu, itāḷu utt.), paklāju un mēbel̦u tirgotāji no Turcijas, Marokas, Indijas un Pakistānas utt. Uzṇēmējiem ne vienmēr ir augstākā izglìtība, bet piemīt citi talanti - gatavība uzņemties risku, vīzija par iespējamo peḷnu, uzsākot uzñēmējdarbību, spēja organizēt darbaspēku un piesaistīt vai izmantot kapitālu uzṇēmējdarbības attīstīšanai.

Starptautiskās organizācijas, piemēram, starptautiskās bankas, lielās korporācijas, attīstot savas filiāles, veicina dažādu augsti kvalificētu uzṇēmumu vadītāju mobilitāti. Veicināt augsta līmeṇa vadītāju cirkulāciju pa dažādām filiālēm ir noteiktu uzṇēmumu mērḳtiecīgi īstenota uzṇēmuma politika. Arī starptautiskie investīciju projekti veicina inženieru un citu augsti kvalificētu speciālistu īslaicīgu migrāciju projekta uzsākšanas posmā.

Talantu migrācija ir vērojama arī saistībā ar kultūras aktivitātēm, tā attiecas uz mūziḳiem, dziedātājiem, rakstniekiem, māksliniekiem, dizaineriem utt., un migrācijas mērḳis ir saistīts ar starptautiskās atpazīšanas iegūšanu. Jānorāda gan, ka šī īpašā grupa, ko nodala Solimano (2008), un arī sportisti ar starptautisku karjeru nav konkrētā pēcdoktorantūras pētījuma mērkigrupa.

Kopumā sociālo zinātṇu literatūrā ir sastopamas dažādas pieejas, kā definēt augsti kvalificētus migrantus. Pieejas ir atkarīgas gan no konkrētās izpētes vietas, gan pētījuma mērḳiem. Augsti kvalificētu migrantu definīcijas nosaka konkrētās sabiedrības vajadzību konteksts, tas, kādas prasmes un kvalifikācija konkrētajā sabiedrībā ir pieprasītas. Būtiski uzsvērt, ka vērojama tendence: augsti kvalificētu migrantu definīcijā mazāka loma tiek pieškirta iegūtajai izglītībai, bet lielāka - nodarbinātībai noteiktos tautsaimniecības sektoros vai profesijās (Kuvik, 2012: 213).

Joprojām būtiska problēma, kas ierobežo augsti kvalificētu migrantu pētniecību, ir starptautiski salīdzināmas longitudinālas statistikas trūkums (Kuvik, 2012: 213). Atsevišķās valstīs tiek apkopota nacionālā statistika par augsti kvalificētiem migrantiem, piemēram, OECD (angl. - Organisation for Economic Co-operation and Development) valstīs ir izveidota datubāze par imigrantu situāciju 2000. gadā, tomēr šī informācija ir ḷoti nepilnīga.

Šajā pētījumā definēts, ka ar augsti kvalificētiem migrantiem tiek saprasti darba migranti ar augstāko izglītību (ISCED 6-8) jeb tie, kas ārvalstīs strādā vai ir strādājuši, pat ja sākotnējā aizbraukšanas motivācija ir cita, piemēram, mācības vai partnerattiecības. Tāpat pētījumā kā mērḳgrupas iekḷauti gan tie, 
kas uzskata, ka tā ir pagaidu migrācija, gan tie, kas uzskata, ka pastāvīgi apmetušies uz dzīvi kādā citā valstī, jo ir nozīmīgi saprast migrācijas motivāciju visām augsti kvalificētu speciālistu migrantu grupām. Jāuzsver, ka ciemošanās vai tūrisma vizītes pētījumā netiek definētas kā migrācija. Lai noteiktu skaidras robežas, par darba migrāciju uz citu valsti tiek uzskatīta situācija, kad persona dzīvo kādā valstī ārpus Latvijas vismaz vienu gadu.

\subsection{GALVENIE GLOBĀLIE PROCESI, KAS SAISTITTI AR AUGSTI KVALIFICĒTU SPECIĀLISTU MIGRĀCIJU, UN LATVIJAS KONTEKSTS}

Augsti kvalificētu speciālistu piesaistīšanā globālais līderis ir ASV, kam seko Lielbritānija, Kanāda, Austrālija, Japāna un citas valstis. Arī dažādas atbalsta politikas augsti kvalificētu migrantu piesaistǐšanai šajās valstīs ir izstrādātas salīdzinoši agrāk nekā lielākajā dạ̣ā Eiropas valstu.

Eiropā augsti kvalificētu speciālistu migrācijai uzmanība ir pievērsta relatīvi nesen. Kopumā pēdējo 20 gadu laikā ir pieaudzis to valstu skaits, kurās ir izstrādāta atbalsta politika augsti kvalificētu migrantu piesaistīšanai. Lai izprastu augsti kvalificētu speciālistu migrācijas procesus Eiropā, nozīmīgākie vēsturiskie notikumi ir gan Pirmais, gan Otrais pasaules karš, kas veicināja augsti kvalificētu speciālistu migrāciju uz ASV. İpaši Otrais pasaules karš un tam sekojošā Latvijas okupācija būtiski ietekmēja arī latviešu izcelsmes augsti kvalificētu speciālistu migrāciju. Šajā laikā veidojās latviešu trimda ASV, Kanādā un Austrālijā, kā arī Eiropas valstīs. Saskaṇā ar vēsturnieku novērtējumiem 1944. gada vasarā un rudenī, tuvojoties Sarkanajai armijai, Latviju kā brīvprāt̄̄gi bēg̣̣i atstāja 265-285 tūkstoši cilvēku (Zelče, 2011: 58).

Būtiski procesi, kas ietekmēja augsti kvalificētu speciālistu migrāciju, aizsākās 20. gadsimta 80. gados, kad globalizācijas ietvaros notika biznesu internacionalizācija, palielinoties ārvalstu tiešajām investīcijām attīstības valstīs. Starptautiskās kompānijas sāka aktīvi veidot savu filiālu tīklu visā pasaulē, un tas sekmēja augsti kvalificētu speciālistu migrāciju. 1990. gadā ASV ieviesa jaunu vīzu politiku attiecībā uz augsti kvalificētu speciālistu migrāciju, un turpmākajos gados līdz 2004. gadam šì politika paplašinājās. Sākotnēji H-1B vīzu kvota bija 65000 augsti kvalificētu speciālistu, bet 1999. un 2000. gadā tā tika paaugstināta līdz 115000 augsti kvalificētu speciālistu, kas bija pieḷaujamais migrantu skaits. 2001., 2002., 2003. gadā H-1B vīzu kvota tika paaugstināta līdz 195 000, bet 2004. gadā tā atkal tika samazināta līdz 1990. gada līmenim. Laika gaitā ir mainījušies dažādi nosacījumi, šobrīd 
H-1B vīza paredz iespēju palikt ASV trīs gadus un uzturēšanās laiku pagarināt līdz sešiem gadiem. Pēc tam iespējams iegūt pastāvīgā iedzīvotāja statusu un ASV pilsonību.

20. gadsimta 90. gadu vidus tiek raksturots ar izmainām attieksmē pret augsti kvalificētu speciālistu migrāciju, pateicoties IT jomas attīstībai un augstajam pieprasījumam pēc IT speciālistiem. Arī kvotu pieaugums H-1B vīzām 2001.-2003. gadā ASV ir saistīts ar IT industrijas lobiju (Kuvik, 2012: 216). Šajā laikā politikas dokumentos un diskusijās parādījās tādi jēedzieni kā "zināšanu ekonomika" un "globālā sacensība par talantiem".

Lai veicinātu tieši augsti kvalificētu speciālistu piesaisti, ap 2000. gadu dažādās Eiropas valstīs tika izveidotas programmas, kas vērstas uz atvieglojumu un atbalsta noteikšanu augsti kvalificētu speciālistu piesaistei. Piemēram, Lielbritānija laikā no 2002. līdz 2008. gadam īstenoja Augsti kvalificēto migrācijas programmu (angl. - The Highly Skilled Migrant Programme). 2000. gadā Vācijas parlaments pieṇēma likumu par Zaḷajām kartēm IT jomas speciālistiem no valstīm, kas nav ES (Bundesanstalt für Arbeit, 2000). Tās l̦āva dzīvot un strādāt Vācijā piecus gadus. Līdzīgus likumus pieṇēma arī Francija un Nīderlande (Pethe, 2007). Plašāk ES migrācijas politika ir raksturota, piemēram, Lūsijas Sernas (Lucie Cerna) un viṇas kolēǵu grāmatās un rakstos (Boucher \& Cerna, 2014; Cerna, 2010, 2011).

Pēdējās divās vai dažviet pēdējās trijās desmitgadēs augsti kvalificēta darbaspēka pieprasījums industrializētajās valstīs ir pieaudzis. No vienas puses, to nosaka ekonomiskā attīstîba pakalpojumu sektorā un pieprasījums pēc tādām profesijām kā IT speciālisti, veselības aprūpes speciālisti, finanšu sektora speciālisti utt. No otras puses, industrializētajās sabiedrībās ir vērojama zema dzimstība un novecošanās, tādēḷ pieprasījums pēc augsti kvalificētiem imigrantiem pieaug (Abella, 2006).

Eiropā masveida augsti kvalificētu speciālistu migrācija no Eiropas austrumiem uz rietumiem aizsākās 1989. gadā. Sākotnēji migrācijas plūsmas bija vērojamas no bijušās Vācijas Demokrātiskās republikas (VDR) teritorijas. Pēc Vācijas apvienošanās saskaṇā ar migrācijas statistiku vairāk nekā divi miljoni iedzīvotāju pārcēlās no VDR uz Rietumvāciju, kā arī mazākā mērā uz Šveici, Austriju un citām Rietumeiropas valstīm (Lang et al., 2016). Migrācija virzienā no austrumiem uz rietumiem aktualizējās arī no citām Centrāleiropas un Austrumeiropas valstīm, un tā būtiski pastiprinājās pēc ES paplašināšanās 2004. gadā un darba tirgus pakāpeniskas atvēršanas ES valstīs. Austrumu-rietumu migrāciju pastiprināja 2008.-2009. gada finanšu un ekonomikas krīze. Kopumā šie procesi veido noteiktu “migrācijas režīmu”, ko 
vairāki Austrumeiropas migrācijas pētnieki raksturo arī kā "plūstošo migrāciju” jeb “likvīdo migrāciju” (angl. - liquid migration) (Glorius, GrabowskaLusinska, \& Kuvik, 2013; Black et al., 2010). Eiropas paplašināšanās rezultātā novērotajiem migrācijas procesiem kopumā ir negatīva ietekme uz Eiropas nosūtošo valstu ekonomisko un demogrāfisko situāciju, jo vērojama tendence, ka biežāk aizbrauc jauni un izglītoti cilvēki. Uzṇēmumiem nosūtošajās valstīs trūkst kvalificētu darbinieku (Lang et al., 2016: 5).

Citu valstu izpētē, piemēram, aplūkojot Indijas un Ḳīnas migrācijas procesus, optimisti augsti kvalificētu speciālistu migrāciju aplūko nevis kā "smadzeṇu aizplūšanu”, bet kā "smadzeņu cirkulāciju” vai pat "smadzeņu ieguvumu” (Harvey, 2008; Saxenian, 2002, 2007). Tomēr arī ārpus Eiropas ne visas valstis iegūst no augsti kvalificētu speciālistu emigrācijas un tai sekojošas remigrācijas. Daudzas zemu un vidēju ienākumu valstis saskaras ar augsti kvalificētu speciālistu trūkumu, jo daḷa no tiem ir aizbraukuši uz valstīm, kuras piedāvā labāku atalgojumu un profesionālās izaugsmes iespējas (Bailey \& Mulder, 2017).

Atsevišķa pētījumu tēma ir arī "smadzeņu izniekošana” vai nepietiekama izmantošana (angl. - brain abuse) (Bauder, 2003; Pietka, Clark, \& Canton, 2013; Trevena, 2013), kad augsti izglītoti speciālisti uzṇemošajā valstī veic mazkvalificētus darbus, kas ilgtermiṇā veicina izglītotu migrantu marginalizāciju. ES un Ekonomiskās sadarbības un attīstības organizācijas ziṇojums parāda (OECD/EU, 2015), ka augsti kvalificēto imigrantu vidū gandrīz divas reizes biežāk ir vērojama situācija, kad speciālists ir pārāk kvalificēts vai augstāk kvalificēts salīdzinājumā ar vietējiem speciālistiem. Pārkvalifikācijas pazīmes sastopamas arī starp augsti kvalificētiem Latvijas emigrantiem (ICF, 2018; Hazans, 2011).

\subsection{MIGRĀCIJAS IZPĒTE DAŽĀDĀS NOZARĒS}

Starptautiskās migrācijas izpēte tiek īstenota dažādās sociālo un humanitāro zinātṇu nozarēs: ekonomikā, socioloǵijā, politoloǵijā, ǵeogrāfijā, demogrāfijā, antropoloǵijā, vēsturē un tiesību zinātnē. Jau vairāk nekā pirms 20 gadiem tika atzīts, ka sadarbība starp sociālo zinātṇu nozarēm ir vāja un migrācijas pētniecībā nav vienotas paradigmas (Massey et al., 1993). Tomēr nozaru pārstāvji savā pētniecībā joprojām norobežojas, lai gan ir arī dažādi mēǵinājumi skatīt migrāciju starpdisciplināri (Brettell \& Hollifield, 2015). Spilgtākie piemēri, kā veidot vienotas starpdisciplināras pieejas, ir Duglasa S. Maseja 
(Douglas S. Massey) vadītajai pētnieku grupai (Massey et al., 1993, 1998), Elizabetei Faselai (Elizabeth Fussel) (2012), kā arī Kārenai O’Rīlijai (Karen O’Reilly) (2012). Daži autori šādas pieejas savukārt vērtē kritiski, jo pētījumos tām ir ierobežotas pielietojamības iespējas (piemēram, Portes, 1997).

Īsumā raksturojot galvenās atšḳirības dažādās nozarēs, var norādīt, ka antropolog̣ijā būtiski ir salīdzinoši pētījumi par dažādām ar migrāciju saistītām izmaiṇām uzṇemošo un izcelsmes valstu kultūrās. Šie pētījumi ir vairāk vērsti uz mikrolīmeni, un tajos uzsvērta konkrētās kopienas konteksta analīze. Piemēram, antropologus interesē, kā migranti uztver un interpretē savu migrācijas pieredzi, ko viṇiem nozīmē būt migrantam, kādas izmaiṇas ir vērojamas, atstājot vienu sabiedrību (kontekstu) un mēǵinot iedzīvoties citā sabiedrībā (kontekstā) (Brettell, 2015).

Demogrāfi analizē populācijas izmaiņas, kas saistītas ar migrācijas procesiem, piemēram, to, kā migrācijas rezultātā izmainās iedzīvotāju kopuma vecums, dzimums, izglītîbas līmenis, nodarbinātība utt., kā arī veido prognožu modeḷus, kā mainīsies iedzīvotāju sastāvs. Ekonomisti makrolīmenī pēta, kā migrācijas procesi ietekmē uzṇemošās un nosūtošās valsts ekonomiku, savukārt mikrolīmenī analizēe, kā indivīdi pieņem migrācijas lēmumus, izvērtējot iespējamos ieguvumus un zaudējumus. Politikas zinātṇu pārstāvji aplūko, kā valsts var kontrolēt migrācijas plūsmas, īstenojot noteiktu imigrācijas, remigrācijas vai pilsonības politiku. Savukārt tiesību zinātne aplūko, kā noteiktas tiesību normas, likumi un noteikumi ietekmē migrāciju. Vēsturnieku pētniecība migrācijas jomā fokusējas uz procesu un fenomenu izmaiṇām laikā, uz to, kas noteiktā periodā mainās vai nemainās saistībā ar migrācijas procesiem. Viena no vēsturei raksturīgākajām pieejām ir periodizācija (Gabaccia, 2015). Savukārt geogrāfu intereses visciešāk ir saistītas ar vietu un telpu, viṇu uzmanības centrā ir telpas un laika attiecības un to saistība ar transnacionālismu, diasporām un sadarbības tīkliem (Hardwick, 2015).

Sociologu pētījumus migrācijas jomā tematiski ir grūti nošķirt no antropologu un cilvēku ǵeogrāfijas pētījumiem, jo galvenie pētnieciskie jautājumi ir līdzīgi: kādi faktori sekmē migrāciju? Kas ir tie, kas migrē, un kas ir tie, kas paliek uz vietas? Kā asimilējas vai citādi akulturējas imigranti? Kāda ir sociālo tīklu nozīme migrācijā? Arī teorētiskajā līmenī visi minēto nozaru pārstāvji ietekmējas no klasiskajām sociālajām teorijām, paradigmām un jēdzieniem, piemēram, cilvēkkapitāls, kultūrkapitāls, sociālie tīkli, transnacionālisms, kritiskā teorija, feminisms utt. Kopumā var secināt, ka l̦oti daudzos gadījumos robežas starp zinātṇu nozarēm ir diezgan mākslīgi veidotas, un migrācijas procesu izpratnei ir jāaplūko visu zinātṇu pienesums. 


\subsection{AUGSTI KVALIFICĒTU SPECIĀLISTU MIGRĀCIJAS TEORIJAS}

N, Nemot vērā to, ka pētnieciskajā laukā augsti kvalificētu speciālistu migrācijai uzmanība tika pievērsta relatīvi nesen, līdz šim tika uzskatīts, ka augsti kvalificētu speciālistu migrācijas izpētei var izmantot plašākas migrācijas procesu teorijas (Kuvik, 2012: 220). Tomēr pēdējo 10 gadu laikā pētījumu un publikāciju skaits par augsti kvalificētu speciālistu migrāciju ir būtiski pieaudzis, un līdz ar to ir arī palielinājies dažādu teorētisko pieeju skaits un mēgénājumi šos migrācijas procesus konceptualizēt. Jāuzsver, ka migrācijas procesus kopumā ir samērā grūti konceptualizēt, jo tos ietekmē gan dažādi aǵenti, gan dažādi motīvi, gan laika un telpas nosacījumi, bet visaptverošām teorijām un teorētiskajiem modeliiem būtu jāspēj sniegt skaidrojumus arī ilgākam laika posmam. Cita būtiska problēma, kādēḷ augsti kvalificētu speciālistu migrācija nav pietiekami izpētīta, ir tāda, ka ar migrāciju bieži vien tiek saprasta pastāvīga pārcelšanās uz dzīvi kādā tālā valstī, bet realitātē daudzos gadījumos tieši augsti kvalificētu speciālistu migrācija ir îslaicīga un pagaidu rakstura.

Vēsturiski pirmās migrācijas teorijas attīstījās divos virzienos - tās, kas vērstas uz makrolīmeṇa analīzi, un tās, kas vērstas uz indivīda rīcības izpratni jeb mikrolīmeni. Migrācijas procesus makrolīmenī nosaka ekonomiskie un politiskie procesi, tajā skaitā konkrētās valstīs vai reǵionos definētās migrācijas politikas, kas noteic, kurš, kad, uz kurieni un kādu iemeslu dēl var migrēt. Makropieejas migrācijas pētniecībā biežāk ir saistītas ar ekonomikas teorijām par ekonomikas attīstību un restrukturizāciju, kā arī strukturālo nosacījumu analīzi. Savukārt mikropieejas koncentrējas uz migrācijas motivāciju un lēmumu pieņemšanu par migrāciju indivīda līmenī, un šajā līmenī nozīmīgas ir pieejas gan ekonomikā, gan antropoloǵijā, gan socioloǵijā (Brettell \& Hollifield, 2015).

Jāuzsver, ka lēmumu pieņemšana par brīvprātīgu migrāciju lielākoties notiek indivīda līmenī. Vienlaikus, pētot starptautisko migrāciju, ir jāṇem vērā arī uzṇemošās un izcelsmes valsts makrolīmeņa faktori, jo valstu îstenotā politika un dažādas institūcijas nosaka situācijas kontekstu, kurā augsti kvalificēts speciālists pieñem lēmumu par migrāciju.

Sākot no 90. gadu beigām, īpaši tiek uzsvērta mezolīmeņa nozīme migrācijas lēmumu pieņemšanā. Viens no ietekmīgākajiem autoriem, kas pievērsa uzmanību mezolīmenim, aplūkojot un pamatojot dažādu organizāciju un sociālo tīklu lomu migrācijas procesos, ir Tomass Feists (Thomas Faist) (1997). Saskaṇā ar T. Feista formulējumu migrācijas procesu analīzē ir jāṇem vērā (1) strukturālais līmenis, kas aptver ekonomiski politiskos un kultūras faktorus uzṇemošajās un nosūtošajās valstīs, (2) attiecību līmenis jeb sociālās 
1.1. tabula. Migrācijas teoriju analīzes līmeṇi

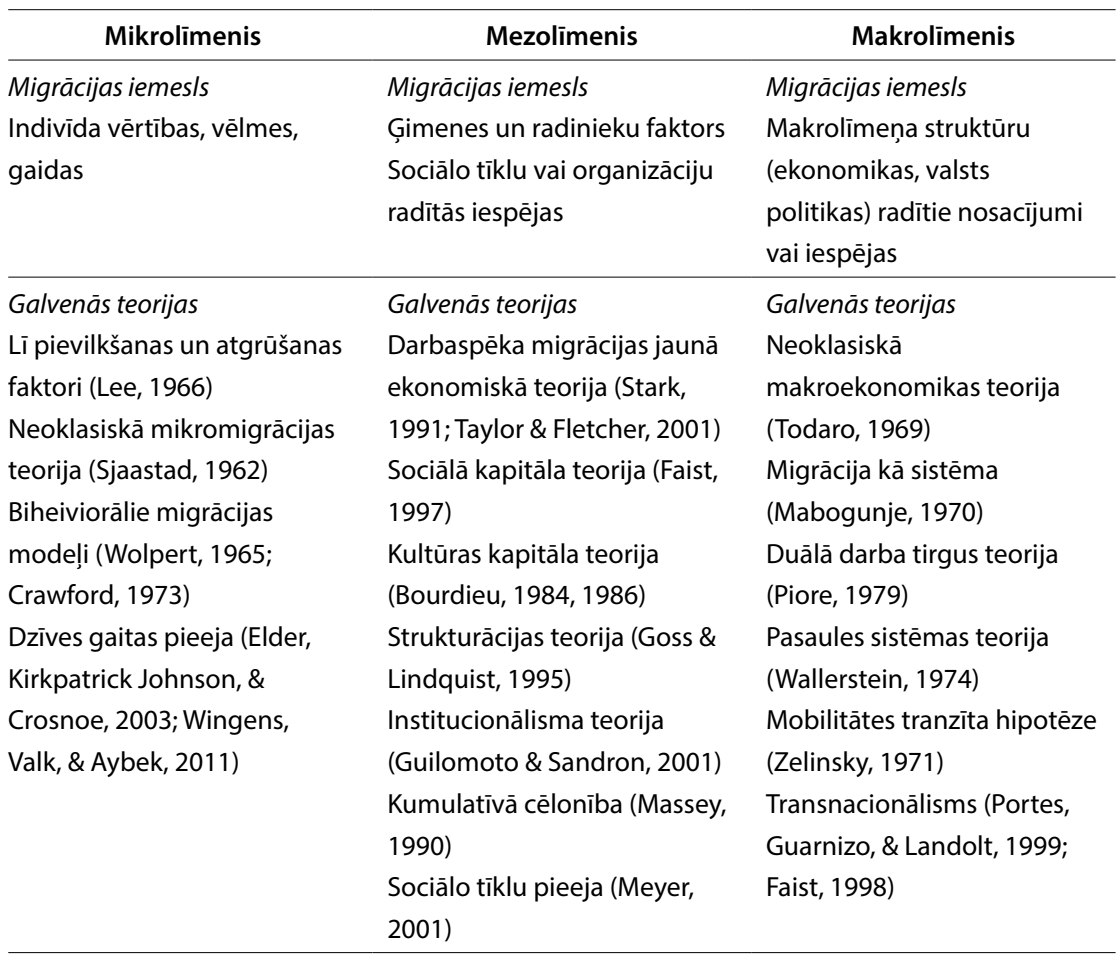

Avoti: Faist, 1997; Hagen-Zanker, 2008; King et al., 2016b.

saites starp aizbraucējiem un palicējiem un (3) indivīda līmenis jeb viṇa iespējas un motivācija pieṇemt migrācijas lēmumus.

Līdz ar to kopumā runāt var par trīs analīzes līmeņiem migrācijas procesu izpētē: makro, mezo un mikro (1.1. tabula).

Atsevišḳi autori veido dažādas modifikācijas analīzes līmeṇu konceptualizācijā. Piemēram, R. Kings un viṇa pētnieku komanda izšķir četrus analīzes līmeṇus: individuālais līmenis jeb mikrolīmenis, g̊imenes/mājsaimniecības (mikro-mezolīmenis), sociālo tīklu un organizāciju līmenis (mezolīmenis) un makrolīmenis (King et al., 2016b). 1.1. tabulā mikro-mezolīmenis ir iekḷauts pie mezolīmeṇa. 
NEOKLASISKĀ EKONOMIKAS TEORIJA AUGSTI KVALIFICĒTU SPECIĀLISTU MIGRĀCIJAS IZPĒTE

Makrolīmen̄̄ augsti kvalificētu speciālistu migrāciju lielākoties aplūko kā darba migrāciju makroekonomiskā kontekstā, un ekonomikas teorijas, jo īpaši neoklasiskā ekonomikas teorija, tiek plaši izmantotas migrācijas procesu skaidrošanā (Kuvik, 2012: 221). Tās pamatā ir pien,ēmums, ka brīva konkurence tirgus ekonomikas apstākḷos sekmē ražošanas efektivitāti, un indivīdi cenšas pārvietoties uz turieni, kur saredz iespējas gūt sev labākos nosacījumus un augstāku labklājību.

Neoklasiskā ekonomikas teorija tiek izmantota arī mikrolīmenī, aplūkojot pievilkšanas un atgrūšanas faktorus, kas veicina indivīda migrāciju, ekonomisko motivāciju aplūkojot kā nozīmīgāko. Viens no pirmajiem pievilkšanas un atgrūšanas faktoru pieeju noformulēja amerikāṇu sociologs Everets S. Lī (Everett S. Lee) (1966). Viṇa pieejā pievilkšanas un atgrūšanas faktori saistīti ar darbaspēka pieprasījumu un piedāvājumu uzṇemošajā un nosūtošajā valstī, un tie papildināti ar citiem pozitīviem vai negatīviem aspektiem (piemēriem, migrācijas normatīvais regulējums, personības īpašības, migrācijas faktoru uztvere), kas sekmē pieṇemt lēmumu par migrāciju vai palikšanu uz vietas. Ar neoklasisko ekonomikas teoriju ir arī saistīts "smadzeṇu aizplūšanas” koncepts.

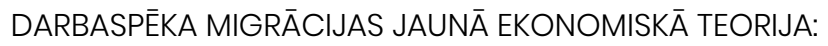

G̦IMENES LOMA MIGRĀCIJAS LËMUMU PIEN̦EMŠANĀ

Cits ekonomikas teorijas virziens - darba migrācijas jaunā ekonomika (angl. - the new economics of labour migration; NELM) būtisku lomu migrācijas lēmumu pieņemšanas analīzē piešķir ǵimenes un radinieku faktoram, aplūkojot nevis situācijas, kad konkrēts indivīds pieṇem lēmumu par migrāciju, bet gan kad migrācija ir stratēǵisks ǵimenes vai mājsaimniecības lēmums (Stark, 1991). Īpaši tā notiek gadījumos, kad migrē nevis visa ǵimene, bet tikai kāds ǵimenes loceklis un daḷu savas algas sūta ǵimenei (angl. - remittances). Kāda ǵimenes locekḷa migrācija līdz ar to ir stratēǵija, kā paaugstināt visas ǵimenes ienākumus un statusu, minimizējot migrācijas riskus. Šajā modelī remigrācija jeb atgriešanās ir plānota migrācijas procesa sastāvdaḷa, jo daudzos gadījumos atgriešanās ir iepriekš paredzēta “kalkulēta stratēǵija”. Veiksmīgas migrācijas pieredzes gadījumā indivīds iegūst plānotos finanšu vai simboliskos resursus - kapitālu, uzkrājumus, izglītību, pieredzi, zināšanas vai kontaktus. Darba migrācijas jaunās ekonomikas teorijas pārstāvji izmanto tādus jēdzienus kā “relatīvie ienākumi” un "relatīvā deprivācija”, jo konkrētās 
mājsaimniecības ienākumi un statuss tiek aplūkoti konkrētās kopienas kontekstā (Stark, 1991: 145).

Biežāk šāds ǵimenes/mājsaimniecības migrācijas lēmumu pieṇemšanas veids ir novērojams tieši lauku mājsaimniecībās, kuras balstās uz agrāro saimniecību, un viena vai vairāku ǵimenes locekḷu migrācija ir uzskatāma arī par risku minimizēšanas stratēǵiju. No vienas puses, ǵimene atbalsta migrantu situācijās, kad viṇam ir grūti (piemēram, migrācijas sākumposmā ir nepieciešami līdzekḷi ceḷam, dzīves uzsākšanai citā valstī). No otras puses, tiek sagaidīts, lai migrants atbalsta savu ğimeni izcelsmes valstī, atdodot daḷu savu ienākumu.

Lai šāds lēmumu pien,emšanas modelis darbotos, ir būtiski, ka konkrētajā sabiedrībā ir spēcīgas ǵimenes vērtības, kolektīvā atbildība un sadarbošanās ğimenes locekḷu starpā (Foster \& Rosenzweig, 2001). Attiecībā uz augsti kvalificētu speciālistu migrāciju šis lēmumu pien,emšanas modelis var būt būtisks arī, pieṇemot lēmumu par izglīīibas iegūšanu ārzemēs: ğimene vai mājsaimniecība jaunietim apmaksā studijas ārvalstīs, par to sagaidot atbalstu vēlākā posmā, kad jaunietis jau kā augsti kvalificēts speciālists būs iekḷāvies darba tirgū.

\section{CILVĒKKAPITĀLA, KULTŪRAS UN SOCIĀLĀ KAPITĀLA TEORIJAS} AUGSTI KVALIFICĒTU SPECIĀLISTU MIGRĀCIJAS IZPĒTE

Vairākos pētījumos par augsti kvalificētu speciālistu migrāciju izmantoti tādi jēdzieni kā cilvēkkapitāls, kultūras kapitāls vai sociālais kapitāls. Ar cilvēkkapitālu tiek saprastas personai piemītošas zināšanas, ieradumi, personības īpašības, tajā skaitā radošums, kas izpaužas kā spēja savas nodarbinātības rezultātā radīt ekonomisku vērtību. Citiem vārdiem, cilvēkkapitāls apzīmē visu personai piemītošo zināšanu un prasmju kopumu. Šo jēdzienu viens no pirmajiem popularizēja Gērijs Bekers (Gary Becker), Čikāgas Universitātes ekonomikas profesors (Becker, 1993 [1964]). Cilvēkkapitāla jēdziens tiek plaši izmantots personāla menedžmenta izpētē un makroekonomikā, tajā skaitā migrācijas ekonomikas teorijās (Massey et al., 1993). Saskaṇā ar cilvēkkapitāla teoriju augsti kvalificētu speciālistu migrācija ir saistīta ar potenciālo migrantu racionālu aprēḳinu, kā vislabāk atgūt izglītībā investētos līdzekḷus.

Kultūras kapitāla jēdziens pēc būtības ir līdzīgs cilvēkkapitāla jēdzienam ar to atšķirību, ka kultūras kapitāls tiek definēts konkrētajā sociālajā un kultūras kontekstā. Piemēram, augsti kvalificēta speciālista zināšanas un prasmes izcelsmes valstī var tikt vērtētas citādi nekā uzṇemošajā valstī. Izpratne par labu izglītību dažādās valstīs atšķiras. To savos pētījumos atklāj daudzi migrācijas pētnieki (Bauder, 2005a, 2005b; Nohl et al., 2006; Weiss, 2004; Erel, 2007, 2010; Ariss \& Jawad, 2011). 
Kultūras kapitāla pieejas galvenais teorētikisis ir Pjērs Burdjē (Pierre Bourdieu), kurš analizēja varas attiecības un sociālo mobilitāti Francijas sabiedrībā (Bourdieu, 1984). P. Burdjē ir definējis trīs dažādus kapitāla veidus: ekonomiskais kapitāls, kultūras kapitāls un sociālais kapitāls. Ekonomiskais kapitāls attiecas uz monetārajiem resursiem un spēju tos vadīt. Sociālais kapitāls attiecas uz līdzdalību dažādās grupās, kas sniedz iespēju saṇemt atbalstu vai īstenot ietekmi. Kultūras kapitāls attiecas uz prasmēm, izglìtību un zināšanām, kas iegūtas socializācijas procesā (Bourdieu, 1986). Kad persona vai kādas grupas apzinās šo kapitālu vērtību, tas transformējas simboliskajā kapitālā jeb noteiktā prestižā, cieņā konkrētas sabiedrības vērtējumā. Migrācijas/ mobilitātes procesā indivīds nonāk citā sabiedrībā, kur ir cita veida priekšstati par simbolisko kapitālu, par to, kas ir vērtīgs un prestižs.

Somu pētniece Sāra Koikalainena (Saara Koikkalainen), balstoties uz P. Burdjē izpratni par ekonomisko, sociālo un kultūras kapitālu, piedāvā analīzes shēmu par migrācijas iespējamo ietekmi uz simbolisko kapitālu (1.2. attēls) (Koikkalainen, 2013). Migrācija sekmē noteiktus ieguvumus un noteiktus zaudējumus, ko var attiecināt uz indivīda ekonomisko, sociālo un kultūras kapitālu. Migrācija var radīt zaudējumus, ja samazinās regulārie ienākumi un pieeja naudas resursiem izcelsmes valstī, bet to parasti kompensē vai cenšas kompensēt ar ieguvumiem uzṇemošajā valstī (jauni/labāki ienākumu avoti ilgtermiṇāâ. Līdzīgi ir sagaidāmi iespējami zaudējumi un ieguvumi attiecībā uz sociālo un kultūras kapitālu. Migrācijas rezultātā bieži vien tiek zaudēti sociālie tīkli un atbalsts izcelsmes valstī, bet tiek iegūti jauni transnacionāli sadarbības tīkli un migrantu kopienas tīkli uzṇemošajā valstī. Migrācijas rezultātā nereti samazinās arī vērtība tām zināšanām, prasmēm un pieredzei, kas bija nozīmīgas izcelsmes valstī, bet tiek iegūtas jaunas zināšanas, prasmes un pieredze, kas ir nozīmīgākas uzṇemošajā valstī (1.2. attēls).

Augsti kvalificētu speciālistu kultūras kapitāla atzīšanu ir pētījušas vairāku pētnieku grupas. Piemēram, starptautiskā kvalitatīvā pētījumā par augsti kvalificētu speciālistu kultūras kapitālu (Nohl et al., 2006) atklājās, ka tajās jomās, kur ir starptautisks darba tirgus, kultūras kapitāls, kas iegūts izcelsmes valstī, biežāk tiek arī starptautiski pieņemts.

Tomēr jebkura migrācija, arī augsti kvalificētu speciālistu migrācija, var radīt "pārejas sodu” (angl. - transition penalty), un var veidoties situācija, ka indivīdam ir jāiegulda ḷoti lielas pūles, lai iegūtu atzinību (Lochhead, 2003; Zikic, Bonache, \& Cerdin, 2010).

Pētījumā par augsti kvalificētiem ungāru un rumāṇu migrantiem Londonā autore Kristīna Čede (Krisztina Csedö) analizē migrantu personisko 
lespējamie zaudējumi:

samazinās regulāri

ienākumi un pieeja

naudas resursiem

izcelsmes valstī lespējamie ieguvumi:

jauni/labāki ienākumu

avoti ilgtermiñã un

pieeja naudas resursiem

uzṇemošajā valstī

\section{Ekonomiskais kapitāls}

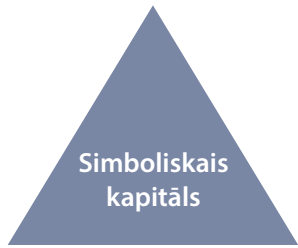

Sociālais kapitāls

lespējamie

lespējamie

zaudējumi: tiek

zaudēti sociälie

tīkli un atbalsts

izcelsmes valstī ieguvumi: jauni

transnacionāli

sadarbīibas tīkli,

migrantu kopienas

tīkli uznemošajā

valstī
Kultūras kapitāls

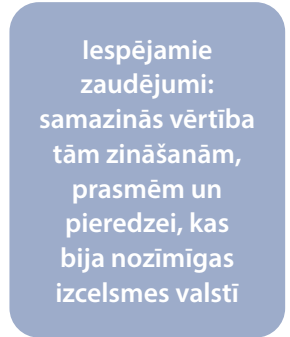

lespējamie

ieguvumi: jaunu

zināšanu, prasmju

un pieredzes

iegūšana, kas

ir nozīmìgäkas

uzṇemošajā valstī

1.2. attēls. Migrācijas iespējamā ietekme uz simbolisko kapitālu

Avots: Koikkalainen, 2013: 48.

ieguldījumu un sociālo kontekstu viṇu kultūras kapitāla atzīšanā Londonā (Csedö, 2008). Viṇa secina, ka tikai tie migranti, kas spējuši pārliecināt par sava kultūras kapitāla vērtību un atrast tam atbilstošu darbavietu, ir uzskatāmi par augsti kvalificētiem speciālistiem. Ja tas nav izdevies un viṇi nestrādā atbilstoši savai kvalifikācijai, viṇi ir tikai augsti izglītoti migranti. Tātad, pārcel̦oties uz dzīvi citā valstī, augsti kvalificētam speciālistam ir darba devējam jāpierāda sava kultūras kapitāla (zināšanu, prasmju un izglītības) atbilstība konkrētajam amatam, pielāgojoties jaunajam sociālajam kontekstam. Profesionālās organizācijas, kas sertificē vai licencē noteiktas speciālistu grupas, parasti vēlas redzēt nacionāli strukturētu karjeru un izglîtību, kas iegūta konkrētajā valstī, kā arī noteiktas valodas zināšanas, un tas apgrūtina migrantu integrāciju darba tirgū. 
SOCIĀLO TITKLU PIEEJA AUGSTI KVALIFICĒTU SPECIĀLISTU

MIGRĀCIJAS IZPĒTEE UN MIGRĀCIJAS INDUSTRIJAS

Mikro-mezo-makroshēmā sociālie tīkli, dažādas organizācijas ir vidusposms starp mikrolīmeni un makrolīmeni, kas palīdz pārvarēt migrācijas barjeras. Piemēram, rekrutācijas firmas palīdz darba devējiem atrast potenciālos migrantus un sagatavo viṇus dzīvei uzṇemošajā valstī. Diasporas organizācijas, sociālie tīkli (radi, draugi, paziṇas) pal̄̄dz migrantiem iekārtoties sākotnējā posmā, atrast mājokli, kārtot administratīvus jautājumus utt.

Migrācijas procesu kumulatīvo raksturu savā pieejā uzsver D. S. Masejs (Massey, 1990), kurš parāda - jo izplatītāki kḷūst migrācijas procesi, jo vairāk veidojas dažādas migrāciju atbalstošas organizācijas, un migrācija turpina pastiprināties. Paplašinoties migrantu sociālajiem tīkliem, migrācija kḷūst par normalitāti un gan uzṇemošās, gan nosūtošās valsts noteiktas kultūras daḷu. Tas savukārt veicina jaunu migrāciju.

Teorētisko ideju attīstībā sociālo tīklu teorijas izmantošana ir nesusi noteiktu konceptuālu pienesumu gan mazkvalificēto, gan arī augsti kvalificētu speciālistu migrācijas izpētē. Tieši analizējot sociālo tīklu ietekmi, atklājās diasporas pozitīvā ietekme uz izcelsmes valsti un konceptuāli tika sākts runāt par "smadzeṇu ieguvumiem” (angl. - brain gain) pretstatā "smadzeṇu aizplūšanai” (Meyer, 2001).

Sociālo tīklu pieeja pētniecībā rada jaunus virzienus: pētīt augsti kvalificētu speciālistu rekrutācijas prakses, ḳēdes migrāciju, kad no vienas apdzīvotas vietas uz citu pārceḷas daudzi iedzīvotāji, transnacionālismu, starptautiskās ekonomiskās sistēmas. 20. gadsimta 90. gados daudzos pētījumos tika analizēta starptautisko kompāniju pieredze speciālistu nosūtǐšanā uz citām valstīm (Findlay, 1990; Findlay \& Garrick, 1990; Findlay, 1995; Findlay \& Li, 1998). Pēc tam pakāpeniski attīstījās arī citu migrācijas kanālu izpēte, pievēršot uzmanību vietējiem uzṇēmumiem ar starptautiskiem līgumiem, kas meklē speciālistus citās valstīs, kā arī rekrutēšanas kompānijām, kurās paši profesionāḷi piesakās, lai meklētu darbu kādā valstī (McCollum et al., 2013).

Viens no salīdzinoši jauniem pētniecības virzieniem/jēdzieniem ir migrācijas industrijas (līdzīgi jēdzieni ir migrācijas bizness vai migrācijas infrastruktūra), kas piedāvā pakalpojumus migrantiem, līdz ar to noteiktā veidā ietekmējot migrācijas procesus (Cranston, Schapendonk, \& Spaan, 2018). Migrācijas industrijas šajā pieejā ir jebkāda veida organizācijas, kas iesaistās migrācijas procesa sekmēšanā: gan profesionāli pakalpojumu sniedzēji (biznesi), gan dažādas brīvprātīgās labdarības organizācijas, gan neformāla atbalsta sniedzēji. Atseviškss pētniecības virziens, kas arī uzskatāms par migrācijas 
industriju pētniecības novirzienu, ir pētījumi, kuros analizēta augstskolu loma augsti kvalificētu speciālistu piesaistīšanā (Ong, Cheng, \& Evans, 1992; Harvey, 2008; Beech, 2017).

\section{DZİVES GAITAS PIEEJA MIGRĀCIJAS PĒTNIECİBĀ}

Dzīves gaitas pieeja attīstìjās 20. gadsimta 60. gados, lai gan viens no pirmajiem pētījumiem, kas tiek saistīts ar šo pieeju, ir Viljama A. Tomasa (William I. Thomas) un Floriana V. Znañecka (Florian W. Znaniecki) pētījums “Poḷu zemnieki Eiropā un Amerikā” (1918-1920), kurā, balstoties uz migrantu personīgajiem dokumentiem, pētīta poḷu migrācija. Dzīves gaitas pieejā tiek pētīta indivīda dzīve un tas, kā agrākie lēmumi vai notikumi ietekmē nākamos, piemēram, laulība, bērnu piedzimšana, migrācija, saslimšana ir noteiktas dzīves pieredzes, kas ietekmē turpmāko dzīvi (Elder, Kirkpatrick Johnson, \& Crosnoe, 2003; Wingens, Valk, \& Aybek, 2011).

Viens no sociologiem, kurš attīstījis dzīves gājuma socioloǵisku izpēti un naratīvās intervijas pieeju, ir Frics Šice (Fritz Schütze). Viṇš savā izpētē izmanto dzīves trajektorijas jēdzienu (Schütze, 1983; Riemann \& Schütze, 1991). Daudzi dzīves gājuma pētījumi, kas izmanto trajektorijas un pagrieziena punkta jēdzienus, ir saistīti ar smagas saslimšanas ietekmi uz dzīves gājumu un tā interpretāciju (Strauss \& Glaser, 1975; Bury, 1982; Latvijā - Skultāne, 2002; Pranka, 2015). Slimība šajos pētījumos aplūkota ne tikai kā pagrieziena punkts, bet arī kā biogrāfiskais pārrāvums. Migrācija biogrāfijas kontekstā var būt un var nebūt pagrieziena punkts indivīda dzīvē. Tomēr ir daudz tādu gadījumu, kad pārcelšanās uz dzīvi citā valstī tiek aplūkota kā jauna situācija, kad indivīds ierauga sevi pilnīgi citā gaismā, un tas var tikt uztverts kā identitātes lūzuma punkts. Tādēl šajā pētījumā migrācijas iespējamās ietekmes raksturošanai piemērotāks jēdziens ir "pagrieziena punkts”, ko piedāvā Deivids Mendelbaums (David Mandelbaum). Saskaņā ar D. Mendelbauma izpratni (Mandelbaum, 1973) pagrieziena punkts indivīdam saistās ar jaunu lomu pien̦emšanu, jaunām attiecībām ar citiem cilvēkiem un jaunu priekšstatu par sevi.

Būtiska vērība dzīves gaitas pieejā tiek pievērsta konkrētās dzīves vēsturiskajam un sociālekonomiskajam kontekstam. Glens Hils Elders (Glen Hill Elder) definē, ka dzīves gaita ir saistīta ar pieciem pamatprincipiem: dzīves ilgumu un attīstību tâs laikā, personas rīcībspēju, vēsturisko situāciju, ǵeogrāfisko vietu, lēmumu pieṇemšanas laiku un saistītajām dzīvēm (Elder, Kirkpatrick Johnson, \& Crosnoe, 2003). Viens no pētniecības virzieniem, kas saista dzīves gaitas pieeju ar migrāciju, ir gimeṇu migrācijas un transnacionālo giimeṇu izpēte (Kilkey \& Palenga-Möllenbeck, 2016). Cits pētījumu virziens, 
kas saistīts ar dzīves gaitas pieeju, ir rīcībspējas un struktūras attiecību izpēte migrācijas procesos (Wingens, 2011).

Poḷu pētniece Izabela Grabovska (Izabela Grabowska), balstoties uz poḷu migrantu pieredzi, pēta rīcībspējas un iespēju struktūru (angl. - opportunity structures) attiecības (Grabowska, 2016). Lai analizētu rīcībspējas manifestāciju darba migrācijas procesos, autore izmanto trīs rīcību veidus: (1) darbību atkārtošana; (2) jaunu darbību veikšana (inovatīvas darbības); (3) darbību izvērtējums jeb refleksivitāte. Darba migrācijas pieredzes izvērtējumā šie rīcībspējas aspekti palīdz atklāt iespēju struktūru konkrētajā kontekstā.

\subsection{INDIVĪDA LĪMENIS: GALVENIE FAKTORI LËMUMU PIEN̦EMŠANĀ}

Indivīda līmenī analizējot migrācijas procesus, pieṇēmums par atalgojuma nozīmi kā galveno pievilkšanas faktoru darbaspēka migrācijā izrādās pārāk vienkāršota pieeja, jo jānnem vērā arī daudzi citi faktori. Īpaši augsti kvalificētu speciālistu migrāciju būtiski ietekmē arī tādi faktori kā karjeras iespēju apsvērumi, uzṇēmuma/organizācijas tēls, kurā plānots strādāt, iespējas attīstīt jaunas prasmes un zināšanas. Tāpat nozīme ir dzives stila preferencēm, priekšstatiem par jauno dzīvesvietu, kā arī ǵimenes apsvērumiem.

Pētnieku grupa R. Kinga vadībā identificējusi trīs galvenās faktoru grupas, kas ir nozīmīgas indivīda mikrolīmeṇa migrācijas analīzē: demogrāfiskie rādītāji, sociālekonomiskie rādītāji un sociālpsiholog̣iskie rādītāji (King et al., 2016b). Par galvenajiem demogrāfiskajiem rādītājiem, kas jāṇem vērā migrācijas procesu analīzē, tiek uzskatīti vecums, dzimums, paaudze un izglītības līmenis. Nozīmīgs rādītājs ir laulības/partnerattiecības, bērni, brāḷu/ māsu skaits, kā arī tas, kurš bērns ǵimenē pēc kārtas ir konkrētais indivīds, jo tas var ietekmēt saistības pret vecākiem. Dažos gadījumos arī noteiktas tradīcijas un mantošanas tiesības ir saistītas ar to, vai indivīds ir pirmais, otrais vai jaunākais bērns ǵimenē.

Aplūkojot sociālekonomiskos faktorus indivīda līmenī, joprojām aktualitāti nav zaudējušas gan jaunās ekonomikas teorijas, gan cilvēkkapitāla teorija. Migrācijas lēmumi tiek pien,emti, izvērtējot, vai migrācijas ieguvumi atsvērs migrācijas “izmaksas” jeb nepieciešamos ieguldījumus (Sjaastad, 1962; Dustman, 2000).

Indivīda līmenī migrācijas lēmumu pieņemšanā nozīmīgas ir sociālpsiholoǵiskās personības iezīmes. Salīdzinot migrantu un “mājās palicēju” psihologiskos raksturojumus, secināts, ka migranti ir vairāk orientēti uz darbu, viniem 

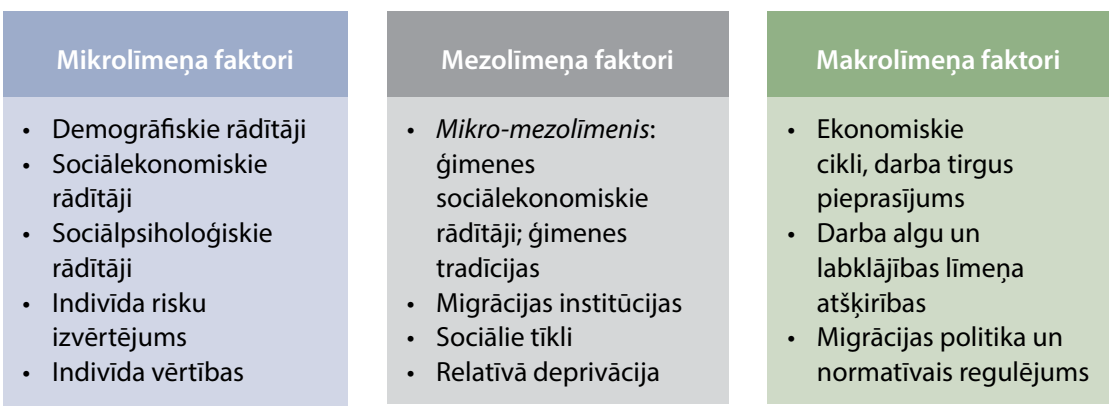

1.3. attēls. Migrācijas lēmumu pieṇemšanā nozīmīgi faktori

Avots: autores kompilācija.

piemīt augstāka sasniegumu motivācija, tieksme pēc varas. Savukārt nemigranti ir ciešāk saistīti ar ǵimeni un savas dzīvesvietas sociālajiem tīkliem (Boneva \& Frieze, 2001). Brīvprātīgie migranti ir arī personības, kas biežāk gatavas uzṇemties riskus un dzīvot nedrošāk, riskantāk (Williams \& Baláž, 2005).

Pēdējo 10 gadu laikā, attīstoties pētījumiem, kas saistīti ar migrantu kultūras kapitāla izpēti, un ietekmējoties no P. Burdjē kultūras kapitāla teorijas (Bourdieu, 1986), sociālo zinātṇu pārstāvji apraksta arī tādu fenomenu kā "transnacionālais habituss" (Kelly \& Lusis, 2006). Tas tiek iegūts starptautiskās migrācijas laikā, pieredzot saskarsmi ar dažādām kultūrām. Līdzīgu jēdzienu lieto arī pētnieki Īrijā, kas īru mobilitāti raksturo ar viṇu kultūrā sakṇotu “mobilitātes habitusu” (Cairns, Growiec, \& Smyth, 2013).

Kopumā teorētiskajā literatūrā apzinātie faktori, kas nozīmīgi migrācijas lēmumu pieṇemšanā, ir apkopoti 1.3. attēlā.

\subsection{ATGRIEŠANĀS MIGRĀCIJAS PĒTNIECİBA: AUGSTI KVALIFICĒTU SPECIĀLISTU POTENCIĀLS NOSŪTOŠO VALSTU ATTITSTİBĀ}

Pēdējo 10 gadu laikā Eiropas pētnieku uzmanību aizvien vairāk saista jautājums par augsti kvalificētu speciālistu remigrācijas ietekmi uz noteiktu reǵionu ekonomisko attīstību. Talantu piesaistī̌sana ir viena no migrācijas politiku stratēgiijām. Augsti kvalificēti speciālisti tiek uztverti kā zināšanu nesēji, kas sekmē zināšanu pārnesi jaunos kontekstos. Augsti kvalificēti speciālisti remigranti var sekmēt sadarbību ar nozīmīgiem partneriem ārvalstīs, tādējādi uzturot zināšanu pārnesi ilgstošā periodā. Augsti kvalificēti speciālisti var būt 


\section{Ekonomiskais kapitāls: migranti kā investori}

\section{Kultūras kapitāls:}

1) migranti kā inovatori: zināšanu nesēji

2) migranti kā inovatori: institūciju mainītāji

Sociālais kapitāls: savienotājfunkcija

REĢIONĀLAIS KONTEKSTS UN INSTITUCIONĀLAIS ATBALSTS

1.4. attēls. Augsti kvalificētu remigrantu potenciālā ietekme uz ekonomisko attīstību Avots: Klein-Hitpaß, 2016: 58.

arī institucionāli inovatori, kas pārnes institucionālas zināšanas no atšḳirīgas vides uz jaunu reǵionu. Vienlaikus pozitīvā ietekme būs vērojama tikai tad, kad migrantiem būs iespēja strādāt atbilstoši viṇu kvalifikācijai un izmantot iegūtās zināšanas, jo tikai tad tās tiks pieņemtas un integrētas kā nozīmīgas (Koser \& Salt, 1997).

Ietekmējoties no P. Burdjē izpratnes par ekonomisko, sociālo un kultūras kapitālu, pētniece Katrīna Kleina-Hitpasa (Katrin Klein-Hitpaß) (2016) analizē iespējamos ieguvumus, kas saistīti ar augsti kvalificētu migrantu atgriešanos izcelsmes valstī (1.4. attēls). Ja uzkrātais ekonomiskais kapitāls var tikt investēts, piemēram, uzṇēmējdarbībā, tad sociālais kapitāls var sekmēt sadarbību starp dažādiem partneriem, savukārt kultūras kapitāls l̦auj ieviest dažādas inovācijas.

K. Kleina-Hitpasa pētījumā par poḷu remigrāciju pēc 1991. gada atklāj, ka tieši 90. gados nozīmīgas bija poḷu remigrantu zināšanas par tirgus ekonomikas organizāciju, vienlaikus remigranti pakāpeniski mainīja dažādu institūciju darbības modeḷus (Klein-Hitpaß, 2016). Līdzīgi, iespējams, arī trimdas latviešu atgriešanās Latvijā noteiktos aspektos sekmēja gan jaunu zināšanu ieguvi, gan jaunas izpratnes veidošanos par dažādu institūciju darbu.

\subsection{TRANSNACIONĀLISMA PIEEJA AUGSTI KVALIFICĒTU SPECIĀLISTU MIGRĀCIJAS IZPËTE}

Sākot no 20. gadsimta 90. gadiem, sociālajās zinātnēs paralēli metodoloǵiskajam nacionālismam, kas vērsts uz vienas valsts konteksta un migrācijas procesu izpēti, attīstìjās transnacionālisma pieeja. Metodoloǵisko 
nacionālismu raksturo situācija, ka migrācijas procesi un migrācijas politikas tiek aplūkotas no nācijas valstu pozīcijām (Wimmer \& Glick-Schiller, 2002: 302; Pries, 2016), taču transnacionālisms uzmanību no nācijas valsts pārvirza uz globāliem migrācijas procesiem, ko vēsturiski lielā mērā ietekmēja globālās ražošanas attīstība (globalizācija), globālu korporāciju veidošanās un ar to saistītās migrācijas attīstība. Transnacionālismu raksturo daudzveidīgās saites un komunikācija, kas notiek starp indivīdiem, grupām, institūcijām pāri nacionālo valstu robežām. 21. gadsimtā pieejamās globālās tehnoloǵijas transnacionālo mobilitāti un komunikāciju tikai veicina. Vairāki autori raksta par transnacionālo sociālo telpu un neskaidrajām nācijas valstu, migrācijas un mobilitātes robežām (Pries, 2016).

Socioloǵijā nozīmīgi teorētiḳi, kas konceptualizēja transnacionālisma pētniecību, ir Alehandro Portess (Alejandro Portes) un T. Feists (skat. Portes, Guarnizo, \& Landolt, 1999; Faist, 1998). Būtiska atziṇa no iepriekš veiktajiem pētījumiem ir saistīta ar transnacionālajiem migrācijas tīkliem un transnacionālo sociālo telpu, kas ir starptautiskās migrācijas rezultāts un vienlaikus arī palielina iespēju, ka migrācija turpināsies no punkta A uz punktu B, uz punktu $C$ utt. ( $A \rightarrow B \rightarrow C \rightarrow D$ ), nevis apstāsies punktā $B$ vai remigrācijas gadījumā $\mathrm{A} \rightarrow \mathrm{B} \rightarrow \mathrm{A}$ (Pries, 2016).

\subsection{NOZĪMĪGĀKIE PĒTIJJUMI PASAULĒ}

Augsti kvalificētu speciālistu migrācijas pētniecība vēsturiski ir attīstījusies vispirms tajās valstīs, kuras tradicionāli tiek uzskatītas par "imigrācijas valstīm”: ASV, Kanādā, Austrālijā un Jaunzēlandē. Sākotnēji pētniecību šajā jomā raksturo vienpusēja pieeja - migrācijas procesi aplūkoti no konkrētās saṇēmējvalsts perspektīvas (Kuvik, 2012: 214).

Sākot no 20. gadsimta 60. gadiem, augsti kvalificētu speciālistu migrācija tiek apspriesta, izmantojot jēdzienu "smadzeṇu aizplūšana”. Šāda pieeja pamatojas uz novēroto augsti kvalificētu speciālistu migrāciju no mazāk attīstītām valstīm uz industriāli attīstītākajām (no “dienvidiem” uz “ziemeḷiem”), uzsverot to, ka nosūtošās valstis ir zaudētājas. Pētījumos tiek atzīts, ka pastāvīga speciālistu pārcelšanās uz dzīvi citā valstī ietekmē gan nosūtošo, gan uzṇemošo valsti, un nosūtošās valstis ir zaudētājas, jo viṇu ieguldījums speciālistu izglītībā nenes augḷus valsts ekonomikai (Adams, 1968; Fortney, 1970).

80. gados līdz ar izmaiṇām augsti kvalificētu speciālistu starptautiskās migrācijas procesos mainījās uzsvari jēdzienu lietojumā (Pethe, 2007). N̦emot 
vērā to, ka šajā periodā vairāk izplatījās augsti kvalificētu speciālistu pagaidu līgumu migrācija un cirkulārā migrācija, augsti kvalificētie speciālisti vairs nepārcēlās uz citu valsti pastāvīgi (Findlay, 1988, 1995; Salt, 1988, 1992; Findlay \& Gould, 1989; Beaverstock, 1990; Findlay \& Garrick, 1990). Pētījumos arvien lielāku uzmanību pievērsa globalizācijas procesiem, globālo ekonomisko centru, globālo pilsētu attīstībai (Beaverstock, 1994, 1996; Beaverstock \& Smith, 1996; Beaverstock \& Boardwell, 2000). Pētniecībai, kuras uzmanības centrā ir valstis, kuras cieš no "smadzeṇu aizplūšanas”, sekoja pētījumi par "smadzeņu cirkulāciju” ar galveno fokusu uz Indiju un K̦īnu, kur “smadzeṇu cirkulācijas” procesiem ir būtiska nozīme šo valstu ekonomiskajā attīstībā. Eiropā, kur imigrācijas politika vēsturiski ir bijusi ierobežotāka un piesardzīgāka, augsti kvalificētu speciālistu migrācija ir salīdzinoši mazāk pētīta.

Saistībā ar IT jomas attīstību 90. gadu vidū pētniecībā aktualizējās interese par augsti kvalificētu datorspeciālistu migrāciju. Īpaši ir jāatzīmē Annalī Saksenianas (AnnaLee Saxenian) pētījumi Silīcija ielejā (angl. - Silicon Valley) Kalifornijā (Saxenian, 1999, 2002, 2007). Viṇas darbos aprakstīti "smadzeṇu cirkulācijas” piemēri, kur tieši augsti kvalificēti migranti sekmē zināšanu un tehnoloǵiju pārnesi uz savu izcelsmes valsti.

Eiropā līdz 90. gadu vidum augsti kvalificētu speciālistu migrācijas pētniecībai netika veltìta liela uzmanība. Atsevišḳi pētījumi pievērsās tādām tēmām kā augsta un vidēja līmeņa vadītāju migrācija un starptautiskās korporācijas (Findlay, 1990; Salt, 1983, 1992). Tikai ap 2005. gadu pieauga tādu pētījumu īpatsvars, kuri veltīiti augsti kvalificētu speciālistu migrācijai, skarot gan zinātnieku mobilitāti (Ackers, 2005), gan imigrantu nodarbinātību IT jomā (Leung, 2001), gan augsti kvalificēto speciālistu migrāciju pēc ES paplašināšanās (Ferro, 2004; Csedö, 2008; Guth \& Gill, 2008; Liversage, 2009). Arī tēmai par augsti kvalificētu speciālistu atgriešanos savās izcelsmes valstīs pētnieki pievērsās tikai ap 2005. gadu (Williams \& Baláž, 2005).

Šobrīd aktuāāāās idejas pētniecībā par augsti kvalificētu speciālistu migrāciju ir saistītas ar konkurēšanu par talantiem un cirkulāro augsti kvalificētu speciālistu migrāciju. Tiek aplūkotas pieejas, kā mazināt "smadzeṇu aizplūšanas” negatīvo ietekmi un sekmēt win-win-win situāciju, kurā ieguvēji ir gan uzṇemošā, gan nosūtošā valsts, gan arī pats migrants. Vienlaikus jānorāda, ka win-win-win situācija ir iespējama tikai ar noteiktiem nosacījumiem, jo to ietekmē gan individuāli, gan strukturāli faktori, piemēram, konkrētajā valstī attiecīgajai nozarei ir jābūt pietiekami attīstītai, lai iegūtās zināšanas un prasmes varētu tikt izmantotas. 
Atsevišķs pētniecības virziens, kam šajā pētījumā uzmanība pievērsta tikai garāmejot, ir uzṇemošo valstu politikas, kas vērstas uz augsti kvalificētu speciālistu piesaistīšanu (Boucher \& Cerna, 2014; Cerna, 2010, 2011). Lai gan migrācijas politikas ietilpst makrofaktoru grupā, kas nosaka migrācijas procesus, šajā pētījumā galvenā uzmanība pievērsta izcelsmes valstu remigrācijas un diasporas politikām (skat. 6. nodaḷu "Politikas iespējas un izaicinājumi talantu piesaistǐšanai Latvijai”).

Kā jau minēts, pēdējo 10 gadu laikā publikāciju skaits par migrāciju vispār, tajā skaitā par augsti kvalificētu speciālistu migrāciju, ir būtiski pieaudzis. Par būtisku pienesumu šajā jomā ir uzskatāms žurnāla "Etnisko un migrācijas pētījumu studijas” (Journal of Ethnic and Migration Studies) 2017. gada 43 (16). numurs, kas veltīts tieši augsti kvalificētu speciālistu migrācijai. Šajā numurā kopumā iekḷauti septini raksti par trīs dažādām apakštēmām (Bailey \& Mulder, 2017): (1) augsti kvalificētu migrantu dzimums, identitāte un statuss sabiedrībā; (2) dzīves posmu izvēḷu saistība ar "nozīmīgajiem” citiem (partneri, ǵimeni, darba devējiem) uzṇemošajā un izcelsmes valstī; (3) uzņemošo valstu augsti kvalificētu speciālistu migrācijas politika un uzṇēmēju viedoklis par to.

Gan šajā žurnālā, gan arī citos pēdējo piecu gadu pētījumos aizvien lielāka uzmanība migrācijas pētījumos tiek pievērsta dzimumam. Augsti kvalificētu speciālistu migrācijas pētniecība atklāj, ka darba tirgū visvairāk pieprasīti ir tādi augsti kvalificēti speciālisti, kas ir mobili, fleksibli, tādēḷ visbiežāk tiek piesaistīti jauni, vientuḷi vīrieši (Xiang, 2007; Kirk, Bal, \& Janssen, 2017).

Pētījumā par augsti kvalificētām speciālistēm migrantēm Vācijā atklāts, ka tieši STEM jomās - zinātnē, tehnoloǵijās, inženierzinātnēs un matemātikā - pastāvošās tradīcijas samazina viṇu iespējas atrast darbu šajās jomās (Grigoleit-Richter, 2017). Vienlaikus pētījums parāda: ja kāda sieviete migrante ir iekarojusi noteiktas pozīcijas kā augsti kvalificēta speciāliste, tā vairs neapsver atgriešanos izcelsmes valstī, bet cenšas integrēties uzṇemošajā sabiedrībā, jo, lai ieṇemtu pozīciju darba tirgū un sevi pierādītu, ir investēts ḷoti daudz laika un spēku. Līdz ar to darba migrāciju augsti kvalificētas sievietes biežāk uztver kā ilgstošu vai pastāvīgu.

Vienā no antropologu pētījumiem, kas veltīts Indijas augsti kvalificētu jaunu speciālistu pieredzei Amsterdamā, ir piedāvāts jauns jēdziens - "pārejas situācija” (angl. - liminality) (Kirk, Bal, \& Janssen, 2017). Autori analizē indivīdu lomas, transnacionālo attiecību, geogrāfiskās vietas, kā arī dzīves posma un dzimuma kulturālās konstrukcijas indiešu vidū. Pētījuma dalībnieki 
ir nodarbināti informācijas tehnoloǵiju, inženierzinātṇu un biznesa vadības jomā, tie lielākoties ir vīrieši vecumā starp 25 un 34 gadiem. Autori secina, ka šo augsti kvalificēto migrantu grupu raksturo dubultas pārejas situācija (angl. - double liminality): viṇi pēc studijām vienlaicīgi sāk strādāt, uzsāk pieauguša cilvēka dzīvi un migrācijas rezultātā mācās dzīvot citas kultūras kontekstā. Šĩ grupa savu pieredzi raksturo kā atrašanos starp divām kultūrām: vienu, kurā piedzimuši un uzauguši, un otru, ar ko sastopas Nīderlandē, kā arī apzinās, ka šajā brīdī notiek pāreja no bērnības/jaunības uz pieauguša cilvēka dzīvi. Vienlaikus pētījums atklāj, ka gan viṇi paši, gan viṇu darba devēji un arī Nīderlandes valdība viṇu nodarbinātību un atrašanos Nīderlandē uzskata par pagaidu situāciju.

Cits pētījums šajā žurnālā atklāj, ka augsti kvalificētiem migrantiem no Indijas ir ḷoti ciešas saites ar ǵimenes locekḷiem un paplašināto ǵimeni, un tieši gimenes vajadzības un vēlmes ḷoti bieži ir izšḳirošas, pien̦emot migrācijas lēmumu (Kõu, Mulder, \& Bailey, 2017).

Viens no būtiskiem secinājumiem par augsti kvalificētiem migrantiem, ko l̦auj izdarīt žurnālā apkopotie pētījumi, ir tāds, ka augsti kvalificētu speciālistu gadījumā galvenais migrācijas iemesls parasti ir profesionālo iespēju paplašināšana, savukārt migranti ir ne tikai ekonomiski, bet arī sociāli un kultūras aǵenti, kas apmetas uz dzīvi uzṇemošajā valstī un tur veido savas ǵimenes (Bailey \& Mulder, 2017: 4).

Jaunākajos pētījumos īpaša uzmanība pievērsta tam, kā dzīves gaitas izvēles saistās ar migrācijas lēmumiem. Piemēram, kā migrācijas lēmumus ietekmē partnerattiecību veidošanās, laulība, bērnu piedzimšana, īpašumu iegāde vai pensionēšanās (Clark, 2013; Geddie, 2013; Kõu et al., 2015; Sabharwal \& Varma, 2016).

\subsection{NOZĪMĪGĀKIE PĒTIJJUMI UN ATZIN̦AS LATVIJĀA}

Latvijā pētījumus un analīzi, kas skar augsti kvalificētu speciālistu migrāciju, lielākoties ir veikuši ekonomisti vai ǵeogrāfi. Nozīmīgākie autori, kas aplūkojuši augsti kvalificētu speciālistu emigrāciju un remigrāciju, ir Mihails Hazans, Zaiga Krišjāne, Elīna Apsīte-Beriṇa, Māris Bērziṇš, Aija Lulle un Laura Bužinska.

Z. Krišjāne, E. Apsīte-Beriṇa, M. Bērziṇš un A. Lulle augsti kvalificētu speciālistu emigrācijai ir pieskārušies plašākā migrācijas procesu analīzes kontekstā, taču M. Hazans ir īpaši pētījis “smadzeņu aizplūdes” jautājumu un 
dažādus kvantitatīvos “smadzeṇu aizplūdes” rādītājus (Hazans, 2015). Būtiski uzsvērt, ka sociālās ǵeogrāfijas nozares pārstāvji Z. Krišjāne, E. Apsīte-Beriṇa, M. Bērziņš un A. Lulle ir īstenojoši vairākus starptautiskus projektus emigrācijas jomā un sagatavojoši kopējas publikācijas sadarbībā ar ievērojamiem ārvalstu ekspertiem (Apsite, Lundholm, \& Stjernstrorn, 2012; Findlay et al., 2013; King et al., 2014, 2015, 2016a, 2016b, 2017; King, Lulle, \& Buzinska, 2016; Göler, Krišjāne, \& Bērziṇš, 2014; McCollum et al., 2013, 2017). Z. Krišjānei, E. Apsītei-Beriṇai un M. Bērziṇam ir nozīmīgas publikācijas par Eiropas migrācijas telpas izpēti (Krisjane, Berzins, \& Apsite, 2013; Krisjane, Apsite-Berina, \& Berzins, 2016).

Būtiski pētījumi migrācijas jomas izpētē ir veikti kā promocijas darbi ğeogrāfijā. Elīna Apsīte-Beriṇa izstrādājusi savu promocijas darbu par Latvijas iedzīvotāju migrāciju uz Lielbritāniju (Apsīte-Beriṇa, 2013). Viṇa ir pētījusi migrāciju gan uz Lielbritāniju, gan Zviedriju (Apsite, 2011a, 2011b). Aija Lulle savu promocijas darbu izstrādājusi par Latvijas iedzīvotāju mobilitāti uz Gērsiju (Lulle, 2014). Savā pētniecībā viṇa vairāk ir specializējusies uz augsti kvalificētu speciālistu imigrāciju Latvijā (Lulle, 2005, 2007), kā arī kopā ar Lauru Bužinsku pētījusi Latvijas izcelsmes augstskolu beidzēju pieredzi ārvalstīs (Lulle \& Bužinska, 2017). Vairāki A. Lulles pētījumi ir par vecāka gadagājuma sieviešu migrācijas problemātiku (Lulle, 2018; Lulle \& King, 2016a, 2016b; King \& Lulle, 2016).

L,oti interesants un augsti kvalificētu speciālistu izpētes kontekstā nozīmīgs ir R. Kinga, A. Lulles un L. Bužinskas pētījums, kas saistīts ar jaunajiem Latvijas izcelsmes speciālistiem, kuri augstāko izglītību ieguvuši ārvalstīs, par viṇu iespējām un barjerām zināšanu pārnesei uz Latviju (King, Lulle, \& Buzinska, 2016). Lai gan augsti izglītoti speciālisti, kas izglītību ieguvuši ārvalstīs, varētu tikt uzlūkoti kā iespējamie pārmaiṇu aǵenti izcelsmes valstī, pētījums atklāj, kādi ir galvenie šḳēršli zināšanu pārnesei. Pētījums ir balstīts uz interneta aptaujas $(N=307)$ un padziḷināto interviju $(N=30)$ rezultātiem, un tajā piedāvāts jauns jēdziens - "sociālie pārvedumi” (angl. - social remittance), kas apzīmē zināšanu pārnesi uz izcelsmes valsti. Pētījums atklāj, ka galvenie šḳērṣ̌ıli, kas kavē zināšanu pārnesi uz Latviju, ir Latvijas ierobežotais tirgus, latviešu etniskās grupas privileǵēšana un darbinieku rekrutācijas prakses, kas balstītas uz pazǐšanos, nevis atklātiem sludinājumiem. Līdzīgas tendences atklāj arī pētījums par augsti kvalificētu speciālistu atgriešanos un integrēšanos Lietuvas darba tirgū (Barcevičius, 2015).

Balstoties gan uz statistikas datu, gan aptauju datu analīzi, nozīmīgus kvantitatīvus pētījumus par migrācijas procesiem, tajā skaitā analizējot arī 
augsti kvalificētu speciālistu migrāciju, ir veicis M. Hazans (Hazans, 2011, 2015, 2017, 2018). Piemēram, 2011. gada publikācijā M. Hazans analizē migrācijas procesus no 2000. līdz 2010. gadam un secina, ka ap 2000. gadu pirms Latvijas iestāšanās ES objektīvi pastāvēja diezgan daudz ierobežojumu un šḳēešlı̆u, kas neveicināja aktīvu Latvijas iedzīvotāju migrāciju (nepieciešamība pēc darba aț̣aujām, informācijas trūkums par vakancēm ārvalstīs, dārgi komunikācijas sakari, dārgas aviobiḷetes u. tml.). Šajā situācijā augsti kvalificētiem speciālistiem bija lielākas iespējas atrast darbu ārvalstīs, līdz ar to migrantu plūsmā laikā no 2000. līdz 2003. gadam augsti kvalificētu speciālistu īpatsvars bija augstāks.

Līdz ar 2004. gadu, kad savu darbaspēka tirgu Latvijas valstspiederīgajiem atvēra Īrija, Lielbritānija un Zviedrija, palielinājās migrācijas plūsma arī mazkvalificētu Latvijas iedzīvotāju vidū, jo migrācijas izmaksas mazinājās un darba atrašanā ārzemēs nozīmīgāki kḷuva diasporas sociālie tîkli. Laikā no 2004. līdz 2008. gadam augsti izglītoto (personu ar augstāko izglītību) indivīdu īpatsvars emigrantu vidū samazinājās un kḷuva mazāks nekā Latvijas iedzīvotāju vidū.

Ekonomiskās krīzes iespaidā migrācijas tendences atkal nedaudz izmainījās. Straujais bezdarba līmeṇa kāpums Latvijā 2009. gadā sekmēja jaunu emigrācijas vilni - lai gan ekonomiskā krīze bija arī citās ES valstīs, tajās bija lielākas iespējas atrast darbu (Hazans, 2011: 74). Tā rezultātā augsti izglītoto indivīdu proporcija emigrantu vidū nozīmīgi pieauga un pārsniedza atbilstošo proporciju Latvijas iedzīvotāju vidū. Saskaṇā ar M. Hazana pētījumu (2011) laikā no 2004. līdz 2008. gadam darba migrācija bija vairāk îslaicīga un emigrantus interesēja mazkvalificēts, îslaicīgs darbs, jo galvenā motivācija bija nopelnīt un atgriezties Latvijā. Savukārt 2009.-2010. gadā vērojama tendence, ka emigranti atstāj Latviju ar visām ǵimenēm un meklē pastāvīgu kvalificētu darbu ES/EEZ valstīs. Saskaņā ar 2010. gada aptaujas datiem tikai viena trešdaḷa aptaujāto augsti izglītoto emigrantu strādāja algotu darbu, izmantojot savu kvalifikāciju, bet $40 \%$ aptaujāto strādāja algotu darbu, neizmantojot savu kvalifikāciju - tas liecina par augsti kvalificētu Latvijas emigrantu pārkvalifikācijas problēmu (Hazans, 2011).

Padziḷināts pētījums par "smadzeṇu aizplūšanas” problēmu ir M. Hazana 2015. gada pētījums "Smadzeṇu aizplūde no Latvijas 21. gadsimtā" (Hazans, 2015), kur autors analizē dažādu indeksu rādītājus, tajā skaitā vecuma specifisko augsti izglìtoto selektivitātes indeksu. Atsaucoties uz OECD kolēgiem (Arslan et al., 2014), atspoguḷots, ka laikā no 2000. gada līdz 2010. gadam “smadzeṇu aizplūdes” rādītājs Latvijā ir pieaudzis par 
5,8 procentpunktiem - no 9,5\% līdz 15,3\% (salīdzinājumam Lietuvā šajā periodā pieaugums ir 5,7, Igaunijā 4,4, bet Polijā 5,1 procentpunkts).

Balstoties uz 2014. gada aptaujas rezultātiem un aprēķinot diasporas selektivitātes indeksu, kas salīdzina katrā mītnes valstī pieaugušo Latvijas emigrantu izglītības līmeni ar Latvijas pieaugušo iedzīvotāju izglītības līmeni, M. Hazans secina, ka diasporas selektivitātes indekss ir pozitīvs lielākajā daḷa valstu, uz kurām emigrējuši Latvijas iedzīvotāji, izṇemot Îriju. Būtisks M. Hazana secinājums attiecas uz jauniešu grupu ar vidējo izglîtību. Viṇa pētījums parāda, ka pēc 2000. gada "smadzeṇu aizplūde” norisinājās gan kā diplomu aizplūde, gan arī kā vidējo izglîtību ieguvušo jauniešu emigrācija viņi augstāko izglītību ieguva jau uzṇemošajā valstī. M. Hazans norāda: līdzšinējās remigrācijas tendences liek uzskatît, ka remigrācija nespēs kompensēt "smadzen̨u aizplūdi”.

Jāuzsver, ka Latvijā nav veikti pētījumi par augsti kvalificētu speciālistu emigrācijas lēmumu pieņemšanu dzīves cikla un partnerattiecību/ǵimenes kontekstā. Vienlaikus zināšanas par migrācijas lēmumu pieņemšanu ir būtiskas, lai izvērtētu remigrācijas un sadarbības ar diasporu politikas potenciālu.

SECINĀJUMI

Migrācijas teoriju un pētījumu apskats liecina, ka migrācijas procesi kopumā, to skaitā arī augsti kvalificētu speciālistu migrācijas jautājumi, ir nozīmīgas pētnieciskās tēmas, par kurām pēdējos gados interese aizvien pieaug.

Aplūkoto migrācijas teoriju salīdzinājums ḷauj secināt, ka tās kopumā nav savstarpēji izslēdzošas vai konfliktējošas, bet cita citu papildina. Indivīdu lēmumi (mikrolīmenis) par migrāciju tiek pieṇemti noteiktā sociālajā kontekstā, kuru raksturo noteikts ekonomiskās attīstības cikls, valsts migrācijas politika un sabiedrībā dominējošās vērtības un attieksmes pret migrāciju (makrolīmenis), kā arī ǵimenes stāvoklis un attieksme pret dzīvesvietas maiṇu un sociālie tīkli, kas sekmē vai nesekmē migrāciju (mezolīmenis).

Indivīda līmenī iespējamā migrācija tiek izvērtēta, ņemot vērā indivīdam zināmos iespējamos riskus un ieguvumus, kā arī ǵimenes un draugu attieksmi un dzīves modeḷus. Kāpēc daži pien̦em lēmumu pārcelties uz citu valsti, bet citi izvēlas palikt? Bez ekonomiskiem faktoriem šeit būtiski ir arī tādi sociālpsihologiiskie aspekti kā gatavība uzṇemties risku, vajadzība pēc drošības, kā arī indivīda izpratne par būtiskākajām vērtībām konkrētajā dzìves posmā. 
Mezolīmenī būtiskas ir gan ǵimenes vērtības un tradīcijas, gan arī jau pastāvošie migrācijas tīkli, kas var sekmēt migrācijas lēmumu pieṇemšanu. Migrācija pati par sevi sekmē noteiktu sociālo tīklu un migrācijas pakalpojumu izveidošanos, līdz ar to atražo pati sevi. Noteiktu iespaidu atstāj arī relatīvā deprivācija, kas raksturīga sabiedrībām ar augstu nevienlīdzības līmeni. Makrolīmenī būtisks faktors ir darbaspēka pieprasījums dažādās apdzīvotajās vietās un reǵionos, kā arī ienākumu atšḳirības un valstu politikas/režīmi migrācijas jautājumos.

Izvērtējot migrācijas ietekmi, būtiski ir nošķirt dažādas analīzes dimensijas. Pirmkārt, pētījumos tiek vērtēta migrācijas ietekme indivīda līmenī: vai plānotie migrācijas ieguvumi atsver migrācijas zaudējumus? Kā notiek indivīda integrācija mītnes valstī? Kā migrācijas ietekmē mainās migranta identitāte? Otrkārt, migrācija ietekmē uzṇemošās valsts situāciju, jo izmaina tās kultūrvidi, sekmē tās ekonomisko izaugsmi u. Tml. Treškārt, migrācijas plūsmas ietekmē izcelsmes valstis, jo tās zaudē darbaspēku, augsti kvalificētu speciālistu gadījumā saskaras ar "smadzeṇu aizplūdes" faktu un Eiropā bieži vien arī ar depopulācijas tendencēm. 
Šìs nodaḷas uzdevums ir atklāt Latvijas augsti kvalificēto emigrantu dzīvi tuvplānā, īpaši viṇu izglītības un darba trajektorijas. Aplūkojot 17 dzīvesstāstus piecās dažādās valstīs, uzmanība pievērsta ar migrāciju saistītajai statusa maiñai ikdienas pieredzēs, galveno fokusu veltot izglītības un darba trajektorijām.

Iespēju robežās analīze aptver gan mikrolīmeni, gan makrolīmeni, gan mezolīmeni. Mikrolīmenī tās ir biogrāfiskās pieredzes, kurās kā "pārejas punkti” izcelti migrācijas notikumi. Mezolīmenī analīze skar dažādu gan institucionalizētu, gan neformālu sociālo tīklu lomu migrācijas procesa sekmēšanā vai iniciēšanā, izglītības un darba trajektoriju veidošanā. Makrolīmenis šajā analīzē atklājas kā politiskais un normatīvais regulējums attiecībā uz migrantu iekḷaušanu konkrētajā valstī, îpaši saistībā ar valodas apguves, izglītības un nodarbinātības jomu.

Analīzē izmantotā pieeja - naratīvo interviju dokumentārā interpretācija (Nohl, 2010; Nohl \& Ofner, 2010) - vērsta uz katra konkrētā dzīvesstāsta 
rekonstrukciju saistībā ar izglītības pieredzi un darba maiṇu. Katru migrācijas stāstu shematiski raksturo attēli, kas iekḷauj izglītības un darba trajektorijas un vairākas dimensijas.

Pirmkārt, attēli ietver notikumu secību attiecībā uz izglītības iegūšanu un darbu konkrētā laikā (notikuma gads vai periods) un saistībā ar noteiktu vietu (valsti), kas ḷauj izsekot migrācijas ietekmei uz izglītības un darba trajektorijām. Šāda pieeja ḷauj shematiski attēlot noteiktus socializācijas un attīstības posmus, piemēram, sākotnēji notiek pagaidu mazkvalificēta darba veikšana un darba meklēšana, izglītības iegūšana uzṇemošajā valstī, tad seko pāreja uz augsti kvalificētu darbu vai uzṇēmējdarbības uzsākšana.

Otrkārt, darba trajektoriju raksturošanai attēlos izmantotas šādas kategorijas: augsti kvalificēts vadošs darbs (ietver augstākā līmen̦a vadītāja vai uzṇēmēja statusu), augsti kvalificēts algots darbs (attēlos izškirts gaišāks un tumšāks krāsojums, kur gaišākais attiecas uz zemāka līmeņa, bet tumšākais uz augstāka līmeṇa augsti kvalificētu darbu, piemēram, ārsts - rezidents vai ārsts - konsultants), mazkvalificēts vai vidēji kvalificēts darbs. Ir iekḷauta ar̄̄ kategorija - bezdarbs / darba meklēšana.

Treškārt, iegūtās izglītîbas raksturošanai izmantoti apzīmējumi Bc., Mg., Dr., kas raksturo izglītîbas līmeņus. Savukārt profesionālā izglītība nozīmē institucionalizētu profesionālo tālākizglìtību kādā apakšnozarē. Vēl atsevišḳi ir nodalītas valodas apmācības, piemēram, valodas kursos vai noteiktās nometnēs vai valodas skolās, jo līdzīgi kā Latvijā valsts valodas zināšanas un to apguve daudzās profesiju grupās ir ḷoti svarīgs priekšnoteikums, lai iekḷautos uzṇemošās valsts darba tirgū.

Ceturtkārt, attēli atklāj arī nozīmīgākos ǵimenes notikumus, kas intervijās minēti profesionālās migrācijas kontekstā, un sadarbību ar tautiešiem gan mîtnes valstī, gan Latvijā (kategorijas: ǵimenes faktori un profesionālā sadarbība ar Latviju). Šāda pieeja ḷauj atklāt statusu pārejas dažādās dzīves jomās un to, kā sabiedrības apakšsistēmas (darba kolektīvs, ǵimene, draugi, profesionālās un interešu organizācijas u. c.) noteiktos dzīves posmos saskaras.

Analīze aptver vairākas empīrisko gadījumu grupas (pēc izglīî̄bas ieguves vietas, pēc profesijas, dzimuma, emigrācijas laika) saistībā ar pieciem dažādiem kontekstiem (Lielbritānija, ASV, Vācija, Zviedrija un Norvēǵija), ko nosaka konkrēto valstu migrācijas un darba tirgus aizsardzības politika.

Visi izvēlētie migrācijas pieredzes stāsti ir savā ziṇā veiksmes stāsti, jo šīs nodaḷas mērḳis ir atklāt profesionālās iespējas un attīstību, emigrējot un integrējoties uzṇemošajā valstī, vai emigrējot un atgriežoties Latvijā. Neveiksmes un šḳēršli tuvāk aplūkoti 3. nodaḷā “Adaptācijas stratēǵijas dzīvei ārvalstīs”. 
Anonimitātes nodrošināšanai biogrāfiju detaļas, kas varētu atklāt informantu identitāti, ir mainītas vai noklusētas. Informantu vārdi ir mainīti. Shematiskie attēli ir veidoti, lai atklātu migrācijas un profesionālās karjeras saistību, un nenodrošina pilnīgu precizitāti attiecībā uz biogrāfiskām detaḷām (piemēram, tajos gadījumos, kad informantiem bijuši arī atsevišķi īstermiņa projekti, kas pārklājas ar citām darba pieredzēm, tie var nebūt iekḷauti, jo attēlos ir ietverti intervijās minētie nozīmīgākie notikumi).

\subsection{LIELBRITĀNIJAS PIEREDZES STĀSTI}

\section{JAUNĀS TEHNOLOG̦IJAS UN JAUNUZN̦ĒMUMI: MĀRTIN̦Š}

Mārtiņa dzīvesstāsta sākums ir atšķirīgs no lielas dal̦as augsti kvalificēto Latvijas emigrantu, jo viṇš ir uzaudzis diplomātu gimenē. Kā bērns, ceḷojot līdzi vecākiem, viņš mācījies starptautiskajās diplomātu bērnu skolās un jau agrīnā vecumā labi apguvis angḷu valodu. Tomēr diplomātu dzīve konkrētā mītnes valstī parasti nav saistīta ar l̦oti ciešu iesakṇošanos tajā, jo ir zināms, ka pēc noteikta laika būs jāpārceḷas uz citu valsti vai arī atpakal uz Latviju. Pēc vidējās vispārīgās izglìtības iegūšanas Mārtiņš pieñēma lēmumu apgūt finanses Nīderlandes augstskolā starptautiskā studiju programmā angḷu valodā. Diemžēl pēc bakalaura studijām atklājās, ka darba perspektīvas nav pārāk daudzsološas, jo Nīderlandes darba tirgū bija nepieciešami speciālisti, kas labi prot holandiešu valodu:

“Izvēelējos Nīderlandi izmaksu dēl, tur viss bija salīdzinoši lēti. [..] Bet tajā Nīderlandes skolā karjeras serviss bija tādā vājā līmenī starptautiskajiem studentiem. Vietējiem tas bija labi, jo daudz lokālo uzñèmumu, taču tie uzṇe-mumi prasīja Nīderlandes valodu, tāpēc palikt negribēju. Bija trešā mācību gada marts vai februāris, kad sāku aktīvi meklēt darbu. Nīderlandē vai Anglijā neatradu neko, ko gribētu, tādẹ̄ pieteicos strādāt Latvijā.”

Pēc bakalaura studijām Mārtiņš atgriezās Latvijā un gadu nostrādāja starptautiskā uzṇēmumā Latvijā, kas sniedz revīzijas, nodokḷu un konsultāciju pakalpojumus. Tur viņš iepazinās ar savu topošo sievu, un tālāk darba un migrācijas plāni tika veidoti arī saistībā ar viṇas profesionālajām un migrācijas izvēlēm. Izvirzījis sev par mērḳi strādāt kādā no lielajām starptautiskajām bankām, Mārtiņš nolēma vispirms iegūt mağistra grādu biznesā un paralēli meklēt darbu. Viena no pieejām darba atrašanā ir sākt ar prakses darbu un tad cerēt, ka, sevi labi parādot, tiks piedāvāta pastāvīga darba iespēja, bet maǵistrantūras laikā Mārtiņam šādu prakses vietu atrast neizdevās: 
“Bija sapnis Londonas bankā pastrādāt. Bija sajūta, ka esmu sevi piečakarējis, jo neesmu pietiekami stipri cīnījies, lai tiktu tajā bankā, tad man bija plāns, ka nu tomēr ir jābrauc. [..] Magistrantūras laikā biju noskaṇots, ka dabūšu to darbu. Ar lielajām bankām process ir tāds ḷoti strukturēts un garš, un tur uz vasaras praksi ir jāpiesakās gadu iepriekš. Bet - kas notika? Lielās bankas, braucot uz mūsu universitāti, meklē darbiniekus vietējam tirgum, kur vajag nīderlandiešu valodu, bet, ja tu raksti pieteikumu bankai pa taisno caur interneta portālu, tad viņi saka, ka, ja tev ir "campus recruitment”, tad tev jāiet uz to, nevis uz mūsu portālu. Tāpēc sanāca, ka man neatbilda ne viens, ne otrs. [..] Tad bija tā, ka magistru esmu pabeidzis, bet darba vēl nav.”

Lēmumu pēc maǵistrantūras Nīderlandē braukt uz Londonu Mārtiņš pieñēma daḷēji draudzenes iespaidā, jo viṇai bija iespēja strādāt Londonā, tādēḷ arī Mārtinş̌ aizbrauca uz Londonu un nolēma meklēt darbu tur, dzīvojot uz vietas. Veidojot jaunus kontaktus, uzzinot no citiem, kā meklēt darbu un sagatavoties intervijai, Mārtinš̌ atrada vairākus darbus, no kuriem pēdējais Londonas darbs atbilst augsti kvalificētam darbam, kas vērsts uz investīcijām jaunajās tehnologijīās:

“Izdomāju, ka nepadošos. Draudzene aizbrauca uz Angliju, kas man deva iespēju arī braukt uz Angliju un uz vietas intervēties. Tad es sāku runāt ar tādiem cilvēkiem, kurus finanšu pasaulē dēvē par "non-target”. Tas ir, kad tu esi gājis "non-target” skolā un ir tāds "non-target” CV. Es prasīju, kā viṇi to dara, un tas veids tiešām ir rakstīt neskaitāmiem uzṇēmumiem un mēgeināt dabūt intervijas.”

Tomēr būtiski uzsvērt, ka Mārtiņam darba meklēšana prasīja lielas pūles, jo pozitīvs rezultāts ir sagaidāms, tikai aizrakstot ḷoti lielam skaitam uzṇēmumu, tas rezultējas ar daudzām darba intervijām, bet reālu darba piedāvājumu ir pavisam nedaudz. Mārtiņš intervijā norāda, ka nosūtījis ap 100 pieteikumu un piedalījies vismaz 50 darba intervijās. Uzṇēmumā, kas bija pēdējais, kurā Mārtiṇš strādāja Londonā, viṇu ieteica kāds šì uzṇēmuma darbinieks, kuru Mārtiṇam izdevās sastapt un iepazīt un kurš viṇam palīdzēja sagatavoties intervijai:

“Ar laiku sapazinos ar cilvēkiem, kas jau strādāja tajos uzṇēmumos. Tajā firmā bija tā, ja tu kā strādājošais tur iesaki kādu cilvēku firmai un šis cilvēks tur dabū darbu, tu saṇem 7,5 tūkstošus mārciṇu. Līdz ar to tam čalim, kuru pazinu, bija interese mani ieteikt un sagatavot tai intervijai. Beigās spīdoši 
viss sanāca. Tiku vēl vienā citā uzṇēmumā, bet tur bija nevis par tehnologiijām, bet dabas resursiem. Izvēlējos tehnologiijas."

Līdzīgi kā daudziem Latvijas emigrantiem, pirmais pusgads jaunajā darbā ir mācekḷa vai praktikanta laiks. Pēc pirmajiem sešiem mēnešiem, ja esi sevi labi parādījis, vari saṇemt paaugstinājumu, pēc kāda laika - atkal nākamo paaugstinājumu, bet pēc nostrādātiem diviem gadiem un trīs mēnešiem Mārtiņš iesniedza atlūgumu, lai atgrieztos Latvijā. Galvenais iemesls, lai atgrieztos, bija draudzenes, topošās sievas, vēlme atgriezties Latvijā. Tomēr svarīgs iemesls kaut ko mainīt bija arī nogurums no smagā darba un brīvā laika trūkums:

“Tad draudzene pateica, ka grib braukt atpakal, un man pašam arī bija apnicis tas smagais darbs. Nebija tā, ka bija neinteresants, bet muļ̣īgi strādāt visas stundas diennaktī. Vienīgais, ko dabū pretī, ir liela alga, bet priekš kam man to vajag, ja man nav laika dzīvot. Kādu gadu pirms tam izlēmām, ka brauksim atpakaḷ, un kādus trīs mēnešus pirms brauciena apprecējāmies Latvijā. Tas datums atlūgumam tika nolikts tāds konkrēts, septembra beigas, jo tajā dienā man izmaksāja bonusu, un tajā pašā dienā aizgāju prom, jo bonuss sastāda kādus $40 \%$ no visas kopējās gada algas. Es to pat tuvākajiem draugiem neteicu, ka eju prom, jo, ja kāds uzzina, tad tev var to bonusu neizmaksāt vai atlaist. Mēs bijām trīs cilvēki, kas tajā dienā aizgāja. Tas galvenais lēmums bija saistīts ar dzīves kvalitāti. Protams, alga ir liela, bet dzīves kvalitāte ir zema."

N̦emot vērā to, ka Mārtiṇam atgriešanās Latvijā saistās ar gimenes veidošanu, kā būtisku atgriešanās faktoru viṇš min arī Latvijā pieejamo maternitātes un vecāku pabalstu, kas salīdzinājumā ar Lielbritāniju ir ievērojami pievilcīgāks:

"Liels faktors Latvijā ir bērnu, grūtniecības pabalsts. Anglijā tas ir nožēlojami mazs, sešas nedēlas, bet Latvijā tas ir ilgāks.”

Atgriezies Latvijā, Mārtiņš izmantoja dažādas darba iespējas, bet saprata, ka viṇa zināšanām un interesēm piemērotu darbavietu nav. Tādēḷ viņš nolēma veidot pats savu uzṇēmumu. No sākuma viṇš vēlējās nodarboties ar uzṇēmumu pārdošanu, bet tad mainīja virzienu un sāka strādāt ar jauno tehnoloğiju ideju īstenošanu:

“Latvijā sapratu, ka tam, ko darīju Londonā, tieša pielietojuma nav. Manam darbam un spējām īsti Latvijā vietas nav. [..] Ar laiku izdomāju, ka tomēr 


\begin{tabular}{|c|c|c|c|c|c|c|c|c|c|c|c|c|c|}
\hline & 2002 & 2008 & 2009 & 2011 & 2012 & 2013 & 2014 & 2014 & 2015 & 2016 & 2017 & 2018 & 2019 \\
\hline Mitnes valsts & \multicolumn{2}{|c|}{$\begin{array}{l}\text { LV/Šveice/ } \\
\text { Kanāda/ }\end{array}$} & \multicolumn{2}{|c|}{ Niderlande (NL) } & \multicolumn{2}{|c|}{ LV } & NL & \multicolumn{3}{|c|}{ Lielbritānija (UK) } & \multicolumn{3}{|c|}{ Atgriezies Latvijā } \\
\hline $\begin{array}{l}\text { Augsti kvalificēts } \\
\text { vadošs darbs }\end{array}$ & & & & & & & & & & & & \multicolumn{2}{|c|}{$\begin{array}{l}\text { Uzṇēmēj- } \\
\text { darbïba LV }\end{array}$} \\
\hline $\begin{array}{l}\text { Augsti kvalificēts } \\
\text { algots darbs }\end{array}$ & & & & & \multicolumn{2}{|c|}{$\begin{array}{l}\text { Darbs } \\
\text { LV }\end{array}$} & $\begin{array}{c}\text { Darbs } \\
\text { NL }\end{array}$ & $\begin{array}{l}\text { Darbs } \\
\text { UK }\end{array}$ & \multicolumn{2}{|c|}{$\begin{array}{l}\text { Darbs } \\
\text { UK }\end{array}$} & $\begin{array}{l}\text { Darbs } \\
\text { LV }\end{array}$ & & \\
\hline $\begin{array}{l}\text { Mazkvalificēts } \\
\text { darbs }\end{array}$ & & & & & & & & & & & & & \\
\hline Izglitîba & & & \multicolumn{2}{|c|}{ Bc. (NL) } & & \multicolumn{2}{|c|}{ Mg. (NL) } & & & & & & \\
\hline $\begin{array}{l}\text { Valodas } \\
\text { apmāciibas }\end{array}$ & \multicolumn{2}{|c|}{$\begin{array}{c}\text { Mācības } \\
\text { starptautiskā } \\
\text { skolā }\end{array}$} & & & & & & & & & & & \\
\hline \multicolumn{14}{|l|}{$\begin{array}{l}\text { Bezdarbs / darba } \\
\text { meklēšana }\end{array}$} \\
\hline G̦imenes faktori & \multicolumn{2}{|c|}{$\begin{array}{l}\text { Diplomātu } \\
\text { ǵimene }\end{array}$} & & & & \multicolumn{2}{|c|}{$\begin{array}{c}\text { lepazinies ar sievu } \\
\text { LV }\end{array}$} & \multicolumn{3}{|c|}{ Sievai darbs UK } & \multicolumn{3}{|c|}{$\begin{array}{l}\text { Plānota ǵimenes } \\
\text { atgriešanās LV }\end{array}$} \\
\hline $\begin{array}{l}\text { Profesionāla } \\
\text { sadarbība ar } \\
\text { Latviju }\end{array}$ & & & & & & & & & & & & & \\
\hline
\end{tabular}

2.1. attēls. Dzīves un darba trajektorijas. 1. Vỉrietis, 28 gadi, specializācija jaunajās tehnoloǵijās, jaunuzṇēmuma vadīšanā, Lielbritānija, emigrējis 2011. gadā, atgriezies 2017. gadā

taisīšu savu tehnologiiju “startup”, un tas, ko es darīju, es meklēju idejas, kas strādā un kas nestrādā, jo man arvien vairāk bija pārliecība, ka Latvijā ir labi taisīt savu, jo te ir daudz programmètāju un diezgan spējīgu cilvēku, un viṇi ir nogarlaikojušies, jo strādā kaut kādā "support” centrā lielā skandināvu uzṇēmumā. Ja viņiem dos iespēju strādāt interesantākā vidē, viņi labprāt pievienosies komandai. Tās algas ir salīdzinoši zemas, un var ātri atḷauties tādus augsti kvalificētus cilvēkus."

Mārtiṇa stāsts profesionālajā jomā parāda, kā var veidoties augsti kvalificēta profesionāḷa karjera gadījumā, kad izglītība ir iegūta valstī ar specifisku nacionālo kultūras kapitālu. Ja nav apgūta nacionālās valsts valoda, augsti kvalificētu darbu atrast ir ļoti grūti. Salīdzinoši labākas iespējas šādiem profesionāḷiem atrast darbu ir valstīs, kur saziņas valoda ir angḷu valoda. Mārtiņa piemērs ir nozīmīgs ar̄̄ ar to, ka atklāj migrācijas pieredzi kā daudzdimensionālu statusa maiṇu, jo, piemēram, lēmums doties uz Londonu un pēc tam atgriezties Latvijā ir saistīts ar attiecībām un ǵimenes veidošanas iecerēm, un atgriešanās Latvijā ir laikus plānota, bet paralēli šie lēmumi tiek saistīti arī ar profesionālām iecerēm. 


\section{KARJERA DIGITĀLAJĀ MĀRKETINGĀ: MIĶELIS}

Miḳeḷa darba pieredze ir gadījums, kad savienojas vairākas zināšanu jomas, konkrēti, finanses, reklāma un programmēšana, jo viṇa specialitāte ir digitālais mārketings. Pēc bakalaura un maǵistra grāda iegūšanas finanšu jomā un pēc darba pieredzes ar IT projektiem un finansēm Latvijā 2010. gadā Miķelis saskārās ar darba devēja vēlmi samazināt algu ekonomiskās krīzes iespaidā, tas viṇam nepatika un lika pārdomāt iespējas meklēt darbu ārvalstīs. Pirmo darbu Londonā viņš atrada, izmantojot savus sakarus jauniešu organizācijā Junior Achievement, kurā aktīvi darbojās:

“Bija tas laiks, kad krīze globāli bija iestājusies pilnā sparā. Bija pārrunas ar tālaika darba devēju, un bija izteiktas vienā teikumā nesavienojamas tēzes, ka darba devējs ir apmierināts ar darbu un tā tālāk, taču vienīgais, uz ko es varu skatīties, ir algas samazinājums. Tad es sapratu to, ka tas ir kā dzīves signāls, ka jāmeklē kaut kas jauns. Aktīvi darbojos organizācijā “Junior Achievement International”, kur es prasīju, vai kādam nav kādi pazīstami Anglijā. [..] Mani iepazīstināja ar vienu latvieti, kas dzīvo Anglijā. Mums dzimšanas dienas sakrita vienā dienā, tad viņš ieminējās, ka ir viena brīva vieta."

Miḳeḷa pirmā darba atrašanas pieredze atklāj, ka ir gadījumi, kad darbs tiek atrasts l̦oti ātri un nekāda ilgstoša sagatavošanās nenotiek. Tomēr jāuzsver, ka šajā darba atrašanas stāstā nozīmīgi ir iepriekš iegūtie sociālie kontakti, kas palīdzēja ātri atrast darbu. Kā redzams vairākos augsti kvalificēto emigrantu stāstos, pirmais darbs Londonā nav bijis sapṇu darbs, un arī Miḳelis nepilnu divu gadu laikā šajā uzṇēmumā sasniedza karjeras griestus, kas lika meklēt jaunas iespējas:

“Pirmais pusgads bija pasmags, jo katrs vakars, arī sestdienās un svētdienās, tika veltīts, lai uzlabotu prasmes. Pierādīju sevi, tiku tālu. [..] Dubultoju savu algu, sapratu, ka griesti te ir sasniegti.”

Nākamo darbu Miķelis atkal atrada caur sociālajiem tīkliem, bet jau citiem - jauniem, kas tika iegūti, dzīvojot Londonā. Viṇam interesi raisīja iespēja trenēt publisko uzstāšanos Toastmasters klubā, un tur viṇš arī ieguva paziṇas, kas pastāstīja par jauna darba iespējām:

“Kad dzīvoju Latvijā, man daudzi stāstīja par tādu lietu kā “Toastmasters”. Tā ir tāda nevalstiska organizācija pasaules līmenī, kas organizē vietējos klubus, kur cilvēki reizi vienā vai divās nedēḷās sanāk un praktizē publisko uzstāšanos. Latvijā tagad tādi ir divi klubi, Londonā pie simts varētu būt. [..] Tad nu es šeit, Anglijā, sāku tur iet un praktizēt to publisko uzstāšanos. Tādā 
veidā ieguvu jaunus draugus, paziņas. Viens no tiem draugiem pateica, $k a$ ir reklāmas aǵentūra Londonas centrā, kas meklē "Account Director”, man bija interese aiziet. [..] Iepriekšējais uzṇēmums bija mazs, zem 10 cilvēkiem Londonas perifērijā, tad tagad katapultējos iekšā Londonas centrā. [..] Lieli budžeti, lieli klienti. Tas bija vēl viens ātras izaugsmes cikls.”

Sadarbība ar Latvijas speciālistiem digitālajā mārketingā Miḳelim veidojās caur uzṇēmuma filiāli Latvijā. Lai gan sākumā tas neietilpa viṇa amata pienākumos, reiz, brīvdienās būdams Latvijā, viṇš aizgājis uz uzṇēmuma Latvijas filiāli, un tikšanās rezultātā izveidojušās sadarbības attiecības, kas turpinās vēl joprojām. Latvijā Miḳeli aicina arī uzstāties konferencēs par šo tēmu:

"Mani uzaicināja uz konferenci. Vienu reizi, kad braucu uz Latviju personīgu iemeslu dēl, sakontaktējos ar uzṇēmuma filiāli Latvijā, pastāstīju, kā notiek lietas Londonā, izveidojās labas attiecības. Tagad divreiz gadā brauси uz Latviju vadīt apmācības vinu potenciāliem klientiem. Nesen Latvijas pārstāvniecības vadītājs atbrauca uz Londonu, noorganizējām tikšanos, iepazīstinājām ar visu, parādījām, kādu līmeni iespējams sasniegt."

Vienlaikus Miķelis savā jomā atkal jūtas sasniedzis noteiktus griestus un apsver, ko darīt tālāk. Viṇa darbības jomā došanās tālāk ir saistīta ar

\begin{tabular}{|c|c|c|c|c|c|c|c|c|c|c|c|c|c|c|c|}
\hline & 2002 & 2004 & 2006 & 2007 & 2008 & 2009 & 2010 & 2011 & $\mid 2012$ & 2013 & 2014 & 2016 & 2017 & 2018 & 2019 \\
\hline Mītnes valsts & \multicolumn{6}{|c|}{ LV } & \multicolumn{9}{|c|}{ UK } \\
\hline $\begin{array}{l}\text { Augsti kvalificēts } \\
\text { vadošs darbs }\end{array}$ & & & & & & & & & \multicolumn{2}{|c|}{ Darbs UK } & Darb & DS UK & \multicolumn{3}{|c|}{ Darbs UK } \\
\hline $\begin{array}{l}\text { Augsti kvalificēts } \\
\text { algots darbs }\end{array}$ & & $\begin{array}{c}\text { Darbs } \\
\text { LV }\end{array}$ & \multicolumn{2}{|c|}{$\begin{array}{l}\text { Darbs } \\
\text { LV }\end{array}$} & $\begin{array}{c}\text { Darbs } \\
\text { LV }\end{array}$ & $\begin{array}{c}\text { Darbs } \\
\text { LV }\end{array}$ & \multicolumn{2}{|c|}{$\begin{array}{l}\text { Darbs } \\
\text { UK }\end{array}$} & & & & & & & \\
\hline Mazkvalificēts darbs & & & & & & & & & & & & & & & \\
\hline Izglitīiba & \multicolumn{3}{|c|}{ Bc. (LV) } & & \multicolumn{2}{|c|}{ Mg. (LV) } & & & & & & & & & \\
\hline Valodas apmācības & & & & & & & & & & & & & & & \\
\hline $\begin{array}{l}\text { Bezdarbs / darba } \\
\text { meklēšana }\end{array}$ & & & & & & & & & & & & & & & \\
\hline G̦imenes faktori & & & & & & & & & & & & & & & \\
\hline $\begin{array}{l}\text { Profesionāla } \\
\text { sadarbïba ar Latviju }\end{array}$ & & & & & & & & & & & & & & $\begin{array}{l}\text { Sada } \\
\text { ar fil } \\
\text { konfe }\end{array}$ & $\begin{array}{l}\text { arbïba } \\
\text { iāli LV, } \\
\text { erence } \\
\text { LV }\end{array}$ \\
\hline
\end{tabular}

2.2. attēls. Dzīves un darba trajektorijas. 9. Virietis, 35 gadi, IT, Lielbritānija, emigrējis 2010. gadā 
uzṇēmuma maiṇu, arī darbības maiṇu, iespējams, mītnes valsts maiṇu, bet šie lēmumi intervijas laikā vēl bija pienemšanas procesā:

“Uzṇēmuma komanda ir lielākā Londonā, iespējams, arī pasaulē. Lineārā trajektorijā manā disciplīnā agentūrai nav kur kāpt vairāk, un par to man ir pārdomas. Sasniegt Olimpu savā industrijā - tas ir izdarīts. Bet tagad rodas eksistenciālie jautājumi: ko tālāk? [..] Ir varianti strādāt citās valstīs, šobrīd esmu tādās krustcelēs profesionālajā dzīvē."

Kopumā Miḳeḷa piemērs raksturo situāciju, kad augstākā izglītība ir iegūta Latvijā, bet tikai dą̣ēji ir saistīta ar karjeru Londonā. Miḳeļa izaugsmes un karjeras veidošanas pamatā ir nemitīga pašattīstība gan tiešajā darbā, gan arī papildus darbam, piemēram, trenējot publisko runu angḷu valodā vai piedaloties apmācību organizēšanā jauniem uzṇēmējiem un vienlaikus pilnveidojot savas zināšanas pašmācībā. Arī šajā piemērā sadarbība ar Latviju aktualizējas tikai tajā posmā, kad karjerā ir sasniegti nozīmīgi rezultāti, stabilizācija un atzinība mītnes valstī un starptautiski.

\section{ĀRSTA PIEREDZES CEL̦ড̌: KASPARS}

Kaspars no Latvijas emigrēja, jo viṇu neapmierināja Latvijas medicīnas izglītības sistēma. Būdams aktīvists un ieņemdams vadošus amatus jauno ārstu profesionālajā organizācijā, Kaspars saskārās ar pretestību jaunām idejām un nolēma pamest rezidentūru Latvijā un iestāties rezidentūrā Lielbritānijā. Lai to izdarītu, Kaspars no sākuma izveidoja kontaktu ar ārstu speciālistu Lielbritānijā, kas tālāk varētu viṇu ieteikt novērotāja vai stažiera statusā kādā Lielbritānijas veselības aprūpes iestādē:

"Sākumā es atradu to pirmo posmu, ko angliski sauc par "clinical attachment”, amerikāṇiem tā ir "observership”. Tā ir stažěšanās, novērošana. Doma ir šāda: tu esi atbraucis kā ārsts, un tev ir "honorary contract". "Honorary" nozīmē to, ka tev neviens nemaksās, bet tu darīsi, ko tev liek, tu būsi novērotājs. Bet līgums ir, jo Rietumu pasaulē viss balstās uz līgumiem. Esmu palīdzējis šādas prakses izgādāt arī pāris dakteriem no Latvijas. Tātad šāda klīniskā novērotāja galvenais uzdevums ir būt acīgam, runāt un radìt iespaidu savam konsultantam, supervizoram, ka tu esi l̦oti labs ārsts. Rezultāts būs tāds, ka šis vietējais ārsts tad varēs dot tev raksturojumu, jo loti daudz kas balstās uz raksturojumu. Raksturojumu nedod uz rokas, bet šim ārstam var piezvanīt un pajautāt par jums. Raksturojums tātad nozīmē, ka šis ārsts var par tevi izteikties.” 
Kaspars kā stažieris ḷoti ātri saṇēma zemākā līmeṇa ārsta darba piedāvājumu un tad iestājās rezidentūrā:

"Pagāja trīs nedēḷas, kad man piedāvāja darbu. Sistēma ir tāda, ka hierarhijā ir konsultants un vecākā līmen,a vai jaunākā lìmeṇa rezidenti, un vidējā līmen,a ārsti. Tad es dabūju šo zemākā līmen,a darbu, un pēc kādiem četriem mēnešiem es pieteicos un iestājos rezidentūrā. Tātad viss ir jādara soli pa solim. Vispirms ir novērotājs, tad jāatrod kāds darbiṇš, un tad rezidentūra. Ja tev veicas un tu dabū rezidentūru uzreiz, loti labi. Bet parasti tā nenotiek.”

Izvērtējot savu migrācijas pieredzi, Kaspars uzsver, ka sākuma posms svešumā ir diezgan grūts:

"Tas nav tā, ka tu aizbrauc un tev ir viegla dzīve, un ceḷi ir bruǵéti ar zelta ķieǵel̦iem. Tas diezgan tālu tā nav.”

Kaspara pašsajūta ievērojami uzlabojās, kad Lielbritānijā viṇam pievienojās sieva un bērni, kas sākotnēji dzīvoja Latvijā:

"Mans novērojums ir tāds, ka labākais veids, kā aizbraukt, ir aizbraukt ar gimeni. Jo tad tev ir tāda sava mazā vide, mazā salina, kas rada drošǐbu. Un tas ir ḷoti svarīgi. Ja tās nav, kā man bija vienu laiku, tas ir diezgan grūti. [..]

Sieva un bērni laimīgā kārtā spēja man pievienoties Anglijā, kas situāciju mainīja lototi būtiski.”

Brexit situācija Kasparu vairāk motivē pamest Lielbritāniju, tomēr pagaidām viens no iemesliem, kādēḷ tur palikt, ir tas, ka bērni mācās Lielbritānijas skolā, un izglītības sistēma ir augstā līmenī. Salīdzinājumā ar pieredzi Latvijas skolās bērni ir ievērojami apmierinātāki ar skolu Lielbritānijā:

"Es zinu, ka mazāk cilvēku brauc uz Lielbritāniju. Diezgan daudz cilvēku arī aizbrauc. Man pašam arī "Brexit” nekādi neveicināja domas te palikt. Man pašam galvenā doma, kāpēc es tur vēl būšu uz vairākiem gadiem, ir tāpēc, ka bērniem tik labi iet Lielbritānijas izglītības sistēmā. Viniem visiem ir gaišas galvas, un tas ir redzams. Un jāsaka, ka izglītības sistēma Lielbritānijā ir daudz labāka nekā mums. [..] Tās ir mūsdienīgākas metodes mācībām, cilvēkus ieinteresē mācīties. Diemžēl dēlam bija arī pieredze pamācīties Latvijā, un tā nebija pārāk jauka pieredze. [..] Un tas, protams, liek rūpīgi pārdomāt, vai mēs šobrīd varam atgriezties."

Kaspara migrācijas stāsts atklāj ārsta karjeras veidošanas posmus ārzemēs. Lielbritānijā sākumposmā nozīmīgi ir kontakti, lai gūtu iespēju stažēties 


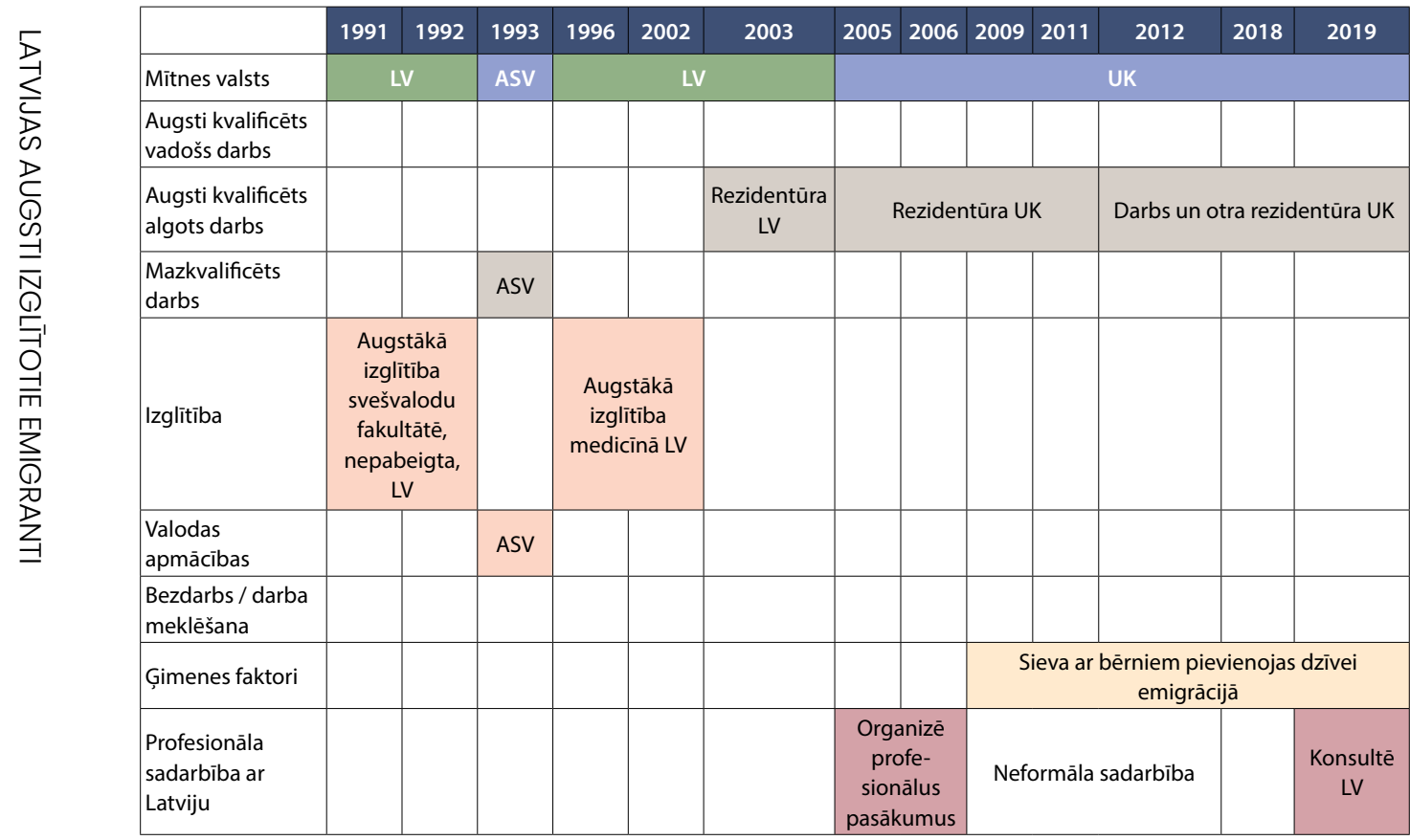

2.3. attēls. Dzīves un darba trajektorijas. 8. Vỉrietis, 48 gadi, ārsts, Lielbritānija, emigrējis 2005. gadā

Lielbritānijas veselības aprūpes iestādē, kā arī varētu risināt sadzīves jautājumus, bet tālāk viss ir atkarīgs no paša iniciatīvas un spējas radīt labu iespaidu, lai saṇemtu darba piedāvājumu un vietu rezidentūrā. Kaspara priekšrocība Lielbritānijas darba tirgū noteikti ir labās angḷu valodas zināšanas, kas iegūtas, gan mācoties svešvalodu fakultātē angḷu valodas novirzienā, gan kādu laiku dzīvojot un strādājot ASV. Viṇa pieredzi pirmajā posmā Lielbritānijā var raksturot kā transnacionālu dzīvesveidu, jo, kamēr viņš strādāja ārzemēs, sieva ar bērniem dzīvoja Latvijā. No intervijā sniegtās informācijas var secināt, ka šāds dzīvesveids bijis psiholoǵiski smags, un Kasparam ir daudz vieglāk, kopš sieva un bērni pārcēlušies uz Lielbritāniju. Būdams sociāli aktīvs, Kaspars visu emigrācijas laiku ir uzturējis neformālus kontaktus ar kolēǵiem un darbojies profesionālās organizācijās, intervijas laikā šīs attiecības jau bija kḷuvušas ciešākas - viņš tiekas ar Latvijas medicīnas studentiem un konsultē par jaunas rezidentūras programmas izveidi. Jāsecina, ka profesionālā ziṇā Kaspars saglabā ciešas saites ar Latviju, lai gan dzīvo un strādā Lielbritānijā. 
Antra intervijas laikā bija 40 gadus veca un dzīvoja Lielbritānijā jau 10 gadus (2.4. attēls). Pārcelšanās uz Lielbritāniju sakrita ar ekonomisko krīzi Latvijā un arī ar Antras vadītā uzṇēmuma strauju lejupslīdi, kam sekoja bankrots, bet ekonomiskā krīze un uzṇēmējdarbības grūtības nebija galvenais emigrācijas iemesls. Antra pārcēlās uz Londonas piepilsētu, jo viṇas vīru, Lielbritānijas pilsoni, bija nepieciešams kopt viṇa slimības laikā. Ekonomiskās grūtības un ǵimenes problēmas sekmēja uzṇēmuma bankrotu Latvijā, jo attālināti vadīt uzņēmumu bija ḷoti sarežǵīti. Pirms tam Latvijā Antra bija ieguvusi izglītību veselības aprūpē un ekonomikā. Intensīvi mācoties un pierādot sevi darbā, bija izdevies izveidot uzṇēmumu, bet vairāku negatīvu apstākḷu sakritība bija iemesls emigrācijai un darba meklējumu uzsākšanai Apvienotajā Karalistē. Apzinoties savas iespējas konkrētajā situācijā, Antra nolēma sākotnēji pastrādāt nozarē, apgūt vietējā tirgus specifiku un tad izvērtēt iespējas veidot savu uzṇēmumu:

“Man tajā brīdī bija tāds skatījums: lai kaut ko uzsāktu, ir jāsaprot šejienes tirgus. Es nolēmu, ka man vajag iegūt kādu pieredzi šeit šajā sfērā. N̦emot vērā manu iepriekšêjo pieredzi kā uzn,ēmuma vadītājai, es nebiju muḷke un šo to sapratu. Bija jāiekḷūst un jāsaprot, kā šeit viss strādā. [..] Bija tas motīvs, ka vajag pastrādāt gadu, un tad pašai kaut ko pasākt.”

Desmit gadu laikā Lielbritānijā Antra ir attīstījusi savu karjeru un strādā prestižā darbavietā - lielā starptautiskā uzṇēmumā atbildīgā amatā, bet sākumā viṇas iespējas un dzīves situācija nebija labvēlīga straujas karjeras veidošanai, jo bija mazs bērns un slims vīrs, vajadzēja arī pelnīt naudu iztikai. Šobrīd Antra neapsver sava uzṇēmuma veidošanu Lielbritānijā, jo ir apmierināta ar karjeru un pēdējo gadu sasniegumiem starptautiskajā uzṇēmumā. Tā vietā Antra brīvajā laikā kopā ar jaunāko bērnu, kas dzimis Lielbritānijā, apmeklē latviešu brīvdienu skolu un aktīvi darbojas, veicinot latviešu diasporas uzṇēmēju tīklošanos:

"Es daudz darbojos ar mūsu tautiešu satuvināšanu un informācijas izplatīšanu par to, kas notiek Latvijā. Lai šì latvietība netiktu zaudēta arī profesionāli. Mums ir dažādi pasākumi, kuros ir veiksmes stāsti, ir informatīvā apmain, gan par uzṇēmējdarbības, gan darba iespējām Latvijā, par eksportu un importu. [..] Man to l̦oti patīk darīt. Nemot vērā, ka es vienmēr esmu vadījusi kādu uzṇêmumu vai organizāciju, man patīk tā virzība, ka tu redzi to attīstību. Uzṇēmējdarbības pieredze pagātnē ir tā, kas man liek to darīt. Tas ir fantastisks process, ka tu redzi to attīstību." 


\begin{tabular}{|c|c|c|c|c|c|c|c|c|c|c|c|c|}
\hline & 1992 & 1995 & 1998 & 2000 & 2004 & 2008 & 2009 & 2011 & 2014 & 2015 & 2017 & 2019 \\
\hline Mītnes valsts & \multicolumn{5}{|c|}{ LV } & \multicolumn{7}{|c|}{ UK } \\
\hline $\begin{array}{l}\text { Augsti kvalificēts } \\
\text { vadošs darbs }\end{array}$ & & & & \multicolumn{2}{|c|}{ Uzṇēmējdarbība LV } & & & & & & & \\
\hline $\begin{array}{l}\text { Augsti kvalificēts } \\
\text { algots darbs }\end{array}$ & & & $\begin{array}{c}\text { Darbs } \\
\text { LV }\end{array}$ & & & \multicolumn{3}{|c|}{ Darbs UK } & & \begin{tabular}{|c|} 
Darbs \\
UK
\end{tabular} & \multicolumn{2}{|c|}{ Darbs UK } \\
\hline $\begin{array}{l}\text { Mazkvalificēts } \\
\text { darbs }\end{array}$ & & & & & & $\begin{array}{c}\text { Darbs } \\
\text { UK }\end{array}$ & & & & & & \\
\hline Izglitïba & & Bc. (LV) & \multicolumn{3}{|c|}{$\begin{array}{c}\text { Bc./Mg. (LV). } \\
\text { Specialitātes maiņa }\end{array}$} & & & & & $\mathrm{PI}(\mathrm{UK})$ & & \\
\hline \begin{tabular}{|l|} 
Valodas \\
apmācības
\end{tabular} & & & & & & & & & & & & \\
\hline $\begin{array}{l}\text { Bezdarbs / darba } \\
\text { meklěšana }\end{array}$ & & & & & & & & & & & & \\
\hline Ģimenes faktori & & $\begin{array}{c}\text { Bērna } \\
\text { piedzimšana }\end{array}$ & & & & $\begin{array}{c}\text { Vira } \\
\text { slimíba }\end{array}$ & & & $\begin{array}{c}\text { Bērna } \\
\text { piedzimšana }\end{array}$ & & & \\
\hline $\begin{array}{l}\text { Profesionāla } \\
\text { sadarbība ar } \\
\text { Latviju }\end{array}$ & & & & & & & & \multicolumn{5}{|c|}{ Diasporas uzṇēmēju tỉklošanās veicināšana } \\
\hline
\end{tabular}

2.4. attēls. Dzīves un darba trajektorijas. 5. Sieviete, 40 gadi, specializācija ekonomikā un uzṇēmuma vadīšanā, Lielbritānija, emigrējusi 2008. gadā

Izvērtējot savu uzṇēmējdarbības pieredzi Latvijā un to, cik tā ir noderīga Lielbritānijā, Antra uzsver, ka Latvijas pieredze viņai ir sniegusi milzīgas zināšanas un spēju rast risinājumus ḷoti sarežğītās situācijās, un tas tiek novērtēts arī Lielbritānijā:

“Šie klupšanas akmeṇi manā ceḷāir devuši man milzīgu pieredzi. Šī pieredze man palīdz joprojām. Jebkurā situācijā es redzu risinājumu. Jebkurai vadībai es varu sniegt padomu, kur un kā darīt."

Arī savu tagadējo darbu, kas ir klasificējams kā augsti kvalificēts algots darbs starptautiskā uzṇēmumā ar kopumā 50000 darbiniekiem visā pasaulē, Antra nevis pati meklēja, bet viņai to piedāvāja, jo nozarē, kurā viṇa strādā, par viņu bija izveidojies labs priekšstats:

“Ja tu esi labs darbinieks, tu esi pamanīts, un tu esi zināms šajās aprindās, šajā vidē. Tevi zina un tevi iesaka, un tādā veidā tas notiek arī šeit."

Rezumējot šī pieredzes stāsta atziņas, var secināt, ka Antras dzīvē un lēmumos, kas saistīti ar darbu un migrāciju, būtiska loma ir ǵimenes faktoriem. Sākotnēji pēc iegūtas izglītības veselības aprūpē dzīves situācija spieda meklēt darbu citā jomā un arī iegūt izglītību citā jomā (ekonomikā), jo bija 
nepieciešams uzturēt sevi un bērnu. Emigrācijas iemesls bija vīra, Lielbritānijas pilsoṇa, slimība, kas noteica arī jaunu karjeras vektoru - strādāt algotu darbu Lielbritānijā un likvidēt uzṇēmumu Latvijā. Bērna piedzimšana Lielbritānijā savukārt radīja pārrāvumu karjerā un nepilnas slodzes darba meklēšanu. Savukārt, bērnam paaugoties, radās iespēja karjeru attīstīt un pilnveidot, vienlaikus arī aktīvi veicinot diasporas uzṇēmēju tīklošanos. Šis piemērs atklāj, ka aktīva iesaistîšnās diasporas pasākumos profesionālā līmenī ir iespējama tikai tad, kad karjera uzṇemošajā valstī un ǵimenes situācija ir nostabilizējusies un kad ir iespējams rast brīvo laiku diasporas aktivitātēm.

\section{ZINĀTNIEKS UN AUGSTSKOLAS PASNIEDZĒJS - MEDICINNAS ZINĀTNE: ROBERTS}

Roberts Latvijā studēja Rīgas Stradiņa universitātē (RSU) un jau otrajā vai trešajā kursā pievērsās biomedicīnas zinātnei. Zinātniskā laboratorija, kurā viņš strādāja, sadarbojās ar universitāti Lielbritānijā, un viṇš vēl studiju laikā vasarās brauca uz turieni veikt zinātniskus eksperimentus. Pēc RSU pabeigšanas log̣isks bija ceḷš braukt uz konkrēto Lielbritānijas universitāti strādāt kā viespētniekam un pēc tam iestāties doktorantūrā. Pēc doktorantūras Roberts pieteicās uz pēcdoktorantūras vietu citā universitātē. Doktorantūras un pēcdoktorantūras laikā Roberts veica pētījumus, uz kuru pamata sagatavoja nozīmīgas zinātniskas publikācijas savā izpētes laukā. Pēc tam Roberts sāka meklēt pastāvīgu darbu Lielbritānijas universitātēs un pēc vairākām intervijām saṇēma divus darba piedāvājumus, no kuriem izvēlējās piedāvājumu Londonā. Kopumā savu karjeras ceḷu Roberts vērtē kā logisku un lineāru un būtiskas grūtības iedzīvoties Lielbritānijā neatceras:

"Es neatceros nekādas fundamentālas grūtības. Protams, ja tu esi doktorants ar ġimeni, finansiālas grūtības var ietekmēt to, ko tu dari. Bet tas tika veiksmīgi pārvarēts. Akadēmiskajā ziṇā es neatceros, ka būtu bijušas grūtības. Bija kādi sīkumi. Piemēram, nesaprašanās ar bosu un tā tālāk. Bet tas gadās visiem un visur. Protams, ka ir diezgan liels stress atrast permanento fakultātes pozīciju pēc postdoka, jo šo pozīciju ir l̦oti maz un konkurence ir l’oti augsta.”

Uz jautājumu par stikla griestiem Lielbritānijas universitātēs un viṇa viedokli par to, vai Lielbritānijā tiek dota priekšroka britiem, Roberts norāda, ka medicīnas zinātnē Lielbritānijā stikla griestu attiecībā uz ārzemniekiem nav un praksē tiek vērtēti konkrētie akadēmiskie sasniegumi. Vienlaikus viņš atzīst, ka iekḷūt sistēmā jeb tikt pie pastāvīgas akadēmiskās darba vietas universitātē ir grūti: 


\begin{tabular}{|c|c|c|c|c|c|c|c|c|c|c|c|c|}
\hline & 1996 & 1999 & 2002 & 2003 & 2004 & 2008 & 2009 & 2013 & 2014 & 2016 & 2017 & 2019 \\
\hline Mītnes valsts & \multicolumn{3}{|c|}{ LV } & \multicolumn{9}{|c|}{ UK } \\
\hline $\begin{array}{l}\text { Augsti kvalificēts vadošs } \\
\text { darbs }\end{array}$ & & & & & & & & & & & \multicolumn{2}{|c|}{ Darbs UK } \\
\hline $\begin{array}{l}\text { Augsti kvalificēts algots } \\
\text { darbs }\end{array}$ & & \multicolumn{2}{|c|}{ Darbs LV } & $\begin{array}{l}\text { Darbs } \\
\text { UK }\end{array}$ & \multicolumn{2}{|c|}{ Pētnieks (UK) } & $\begin{array}{l}\text { Pos } \\
\text { rant }\end{array}$ & $\begin{array}{l}\text { okto- } \\
\text { ra UK }\end{array}$ & \multicolumn{2}{|c|}{ Darbs UK } & & \\
\hline Mazkvalificēts darbs & & & & & & & & & & & & \\
\hline Izglitíba & \multicolumn{3}{|c|}{$\begin{array}{l}\text { Augstākā izglitīiba } \\
\text { medicīnā (LV) }\end{array}$} & & \multicolumn{2}{|c|}{$\begin{array}{l}\text { Dr. medicīnā } \\
\text { (UK) }\end{array}$} & & & & & & \\
\hline Valodas apmācības & & & & & & & & & & & & \\
\hline $\begin{array}{l}\text { Bezdarbs / darba } \\
\text { meklēšana }\end{array}$ & & & & & & & & & & & & \\
\hline G̦imenes faktori & & & & & & & & & & & & \\
\hline $\begin{array}{l}\text { Profesionāla sadarbïba } \\
\text { ar Latviju }\end{array}$ & & & & & & & & & Sada & Dojas a & SU, vies & ektors \\
\hline
\end{tabular}

2.5. attēls. Dzīves un darba trajektorijas. 10. Vîrietis, 42 gadi, medicīnas zinātne, Lielbritānija, emigrējis 2002. gadā

“Es domāju, ka tā ir diezgan būtiska atšķirība starp Lielbritānijas sistēmu un sistēmu, kāda tā ir daudzās vietās Eiropā, piemēram, Itālijā vai Francijā.

Es neredzu stikla griestus. Meritokrātija ir diezgan laba lieta. Tu zini, ka, ja tu izdarīsi to, to un to, tev nebūs problèmu. Bet - ir diezgan grūti ieiet tajā sistēmā."

Šobrīd Roberts aktīvi sadarbojas ar Rīgas Stradiṇa universitāti, kur lasa lekcijas kā vieslektors, piedalās tematiskās konferencēs un kopā ar Latvijas zinātniekiem raksta kopīgus grantu pieteikumus:

“Jā, profesionālā sadarbība pārsvarā ir ar Rīgas Stradiṇa universitāti, kas ir mana “Alma Mater”. Kādu otro vai trešo reizi pēc kārtas mani uzaicināja nolasīt lekciju Zinātnes nedēḷā. [..] Mēs arī mēéginām izveidot formālus zinātniskos sakarus, piemēram, piesakoties kopīgiem Eiropas Zinātnes padomes grantiem. Es mēǵinu būt aktīvs, lai šie sakari attīstītos, un zinātnes attīstības līmenis Latvijā attīstītos ātrāk un labāk. "

Kopumā Roberta pieredzes stāsts atklāj, ka Lielbritānija ir atvērta zinātniekiem no Latvijas, kas strādā ar starptautiski aktuālām izpētes tēmām. Karjeras ceḷš zinātnē viṇam aizsākās Latvijā, bet kā doktorantūras studentam turpinājās Lielbritānijā. Pēc doktorantūras un pēcdoktorantūras studijām, balstoties uz augsti novērtētiem pētījumiem un publikācijām, viṇam izdevās iegūt pastāvīgu darba vietu Lielbritānijas universitātē, kur viṇš jau ieṇem vadošu pozīciju kā pēcdiploma studiju programmas direktors. 
Lielbritānijas pieredzes raksturošanai iekḷauti divi karjeras stāsti, kas saistīti ar jaunajām tehnologijām, viens no tiem ir par karjeru digitālajā mārketingā, otrs - par IT jaunuzṇēmumu veidošanu. Divi stāsti no IT jomas izvēlēti, jo viens stāsts raksturo veiksmīgu karjeru Londonā, otrs - arī veiksmīgu karjeru Londonā, bet ar atgriešanos Latvijā. Stāsti atšḳiras ar iegūtās izglîtības vietu: vienā gadījumā izglītîba ir iegūta Latvijā, un, krīzes iespaidā emigrējot, izveidojusies ḷoti veiksmīga karjera Lielbritānijā; otrā gadījumā izglītība ir iegūta ārpus Latvijas starptautiskā maǵistrantūras programmā, bet laba darba atrašana tik un tā ir bijusi l̦oti darbietilpīga. Divi stāsti spilgti raksturo ǵimenes un attiecību nozīmi migrācijas lēmumu pieṇemšanā: vienā gadījumā giimenes faktors ir bijis iemesls aizbraukt no Latvijas, otrā - atgriezties Latvijā. Četri no aplūkotajiem stāstiem ir interesanti tajā ziṇā, ka atklāj augsti kvalificētu emigrantu sadarbību ar Latviju. Visiem aplūkotajiem stāstiem raksturīgi, ka sadarbība ar Latviju aktualizējusies tieši pēdējos gados, kad profesionālā darba dzīve Lielbritānijā jau ir nostabilizējusies.

\subsection{ASV PIEREDZES STĀSTI}

DOKTORANTŪRA UN ZINĀTNISKĀ DARBA PIEREDZE: IVETA

Ivetas ceḷš uz ASV aizveda nejaušas sakritības dēḷ. Aizvietojot darba kolēgi konferencē, Iveta iepazinās ar latviešu izcelsmes profesori ASV, kura ieteica viņai apsvērt iespēju studēt doktorantūrā ASV. Iveta ne tikai tika uzṇemta doktorantūras studijās, bet arī saṇēma stipendiju, un Latvijā satiktā profesore bija Ivetas promocijas darba vadītāja. Šis ir viens no daudziem piemēriem, kā trimdas latvieši sniedz profesionālo atbalstu latviešu profesionālo zināšanu celšanai ārvalstīs. Tomēr pēc doktorantūras studijām Iveta atgriezās Latvijā vairāku iemeslu dēḷ. Pirmkārt, viņai bija jāpabeidz promocijas darbs, bet ASV bija iestājies tāds posms, kad ir grūti saṇemties, lai to izdarītu. Otrkārt, Latvijā gaidīja partneris, kuram bija veiksmīga karjera Latvijā. Šis stāsts atklāj, ka, līdzīgi kā daudzos citos stāstos, attiecībām un gimenes faktoriem ir liela nozīme migrācijas lēmumu pieṇemšanā:

"Man bija baigais stress, nevarēju kaut kā saņemties to disertāciju pabeigt, un, protams, ir tā, ka tad, kad ir grūti, tad gribas kaut kur citur. [..] Man jau gribējās mājās, pietrūka ǵimenes, draugu, mans draugs. Jo mēs jau sākām draudzēties studiju laikā, tad, kad aizbraucu. Tad četrus gadus turpinājām 
attiecības caur attālumu. Nu tad logiski bija visu laiku tas jautājums, ko tad mēs darīsim, kad es pabeigšu? Man sākumā varbūt bija tā cerība, ka viṇš pārcelsies uz Ameriku, bet viñam bija labs darbs, veiksmīga karjera šeit, un līdz ar to laikam nebūtu godīgi vinam prasīt pārcelties. [..]”"

Vienlaikus ASV pieredze ir l̦oti nozīmīga profesionālajam pavērsienam zinātnes un akadēmiskās darbības virzienā, jo Latvijā Ivetas darba pieredze saistījās ar darbu farmācijas firmā, bet tas viṇai ne visai patika:

"Es nejutos gandarīta ar to savu mācību procesu, gribējās kaut ko vairāk, un es īsti nezināju, ko es gribu darīt. 5. kursā, kad jau bija prakse, es strādāju farmācijas firmā. Tajā brīdī mazliet panika mācās virsū - kā tad būs, es tagad visu mūžu strādāšu ofisa darbu? Un tad es aizbraucu uz konferenci, kur ìstenībā aizbraucu kāda cita cilvēka vietā, jo viṇa bija saslimusi. Un tur bija tā pasniedzēja no ASV universitātes, un es tieši runāju par tēmu, kas bija saistīta ar viñas tēmu. Viña apjautājās, ko es vispār esmu domājusi un ko gribu darīt tālāk. Man vispār nebija tāda doma, ka es varētu studēt doktorantūrā, vispār nebija nekāda tāda plāna."

Pēc atgriešanās Latvijā Ivetas pirmais uzdevums bija pabeigt disertāciju un paralēli meklēt darbu. Pirmais atrastais darbs nebija gluži tas, ko viṇa vēlējās, bet pēc kāda laika parādījās iespējas strādāt universitātē - tas visvairāk atbilda Ivetas vēlmēm, un šajā darbā viņa var izmantot zināšanas, ko apguvusi ASV. Interesanti, ka, dzīvojot ASV, mainījies Ivetas viedoklis par Latviju. Pirms aizbraukšanas Ivetas attieksme bijusi l̦oti kritiska, bet tagad viņa spēj labāk novērtēt to, kas Latvijā ir labs:

"Līdz tam man bija šausmīgi negatīva nostāja pret Latviju, man likās, ka viss ir slikti. Es biju l̦oti negatīva par to situāciju, par dzīvošanu - man likās, ka Latvijā nav vērts dzīvot. Amerikā dzīvojot, es tomēr novērtēju dzīvi Latvijā. Es laikam ieguvu daudz plašāku un kritiskāku skatu gan uz pasaules iekārtu, gan uz to, kā lietas ir iekārtotas, un daudz vairāk novērtēju to, kas mums ir Latvijā, ka nemaz nav tik slikti. Protams, ka ir problēmas, bet visur ir problēmas. [..] Es arī sāku pamanīt, ka ir ḷoti daudz veiksmīgu cilvēku Latvijā. Ir cilvēki, kas dzīvo foršas, interesantas dzīves, darbus strādā un kaut ko sasniedz. Es sapratu, ka daudz kas ir atkarīgs no manis pašas, ka ir svarīgs tas kontakts un resursi."

Ivetas intervija atklāj arī pieredzi, ka atgriešanos no ASV apkārtējie vērtē negatīvi - kā iespēju zaudējumu, “zaudētāja” situāciju: 


\begin{tabular}{|c|c|c|c|c|c|c|c|c|c|c|}
\hline & 2003 & 2004 & 2007 & 2008 & 2009 & 2011 & 2012 & 2013 & 2014 & 2019 \\
\hline Mītnes valsts & \multicolumn{4}{|c|}{ LV } & \multicolumn{3}{|c|}{ ASV } & \multicolumn{3}{|c|}{ LV } \\
\hline $\begin{array}{l}\text { Augsti kvalificēts } \\
\text { vadošs darbs }\end{array}$ & & & & & & & & & \multicolumn{2}{|c|}{ Darbs LV } \\
\hline $\begin{array}{l}\text { Augsti kvalificēts algots } \\
\text { darbs }\end{array}$ & & \multicolumn{2}{|c|}{ Darbs LV } & Darbs LV & \multicolumn{3}{|c|}{ Pētniece (ASV) } & Darbs LV & & \\
\hline Mazkvalificēts darbs & & & & & & & & & & \\
\hline Izglitīiba & \multicolumn{4}{|c|}{ Augstākā izglîtība medicīnā (LV) } & \multicolumn{3}{|c|}{ Dr. farmācijā (ASV) } & & & \\
\hline Valodas apmācības & & & & & & & & & & \\
\hline \multicolumn{11}{|l|}{$\begin{array}{l}\text { Bezdarbs / darba } \\
\text { meklěšana } \\
\end{array}$} \\
\hline G̦imenes faktori & & & & & \multicolumn{3}{|c|}{ Draugs Latvijā } & & & \\
\hline $\begin{array}{l}\text { Profesionāla sadarbība } \\
\text { ar Latviju }\end{array}$ & & & & & & & & & & \\
\hline
\end{tabular}

2.6. attēls. Dzīves un darba trajektorijas. 14. Sieviete, 36 gadi, farmācija, ASV, emigrējusi 2008. gadā, atgriezusies 2012. gadā

"Neviens neticēja, vispār bija l̦oti negatīva attieksme, kad es atbraucu. Kad braucu prom, visi to redzēja kā nozīmīgu sasniegumu. [..] Atgriešanos vērtēja negatīvi. Es dzirdēju dažādus viedokḷus. Atgriežas tie, kas ir "lūzeri”, atgriežas tie, kam tur negāja, atgriežas, jo nevarēja tur dabūt darbu.”

Kopumā Ivetas ASV pieredze atklāj vairākus būtiskus augsti kvalificētu profesionāḷu migrācijas aspektus. Pirmkārt, tā parāda iespējamo pozitīvo ārvalstu latviešu ietekmi uz mācībām ārvalstīs un turpmāko karjeru. Otrkārt, tā atklāj, ka pēc atgriešanās Latvijā ir iespējams veidot sekmīgu akadēmisko karjeru un izmantot iegūtās zināšanās. Treškārt, Ivetas pieredze parāda, cik nozīmīgas lēmumu pieṇemšanā ir attiecības un ǵimenes faktori.

\section{REZIDENTŪRA UN ĀRSTA DARBS: REINIS}

Reinim studijas Latvijas Medicīnas akadēmijā sakrita ar pārmaiņu laikiem Latvijā (1988.-1994. gads), un pēc studiju beigām viṇš Latvijā laba darba perspektīvas nesaskatīja. Tādēl Reinis pien̦ēma izaicinājumu doties uz rezidentūru ASV. Pateicoties trimdas latviešu un Dr. Jura Lazovska atbalstam, Reinis nokārtoja nepieciešamos eksāmenus un atrada vietu rezidentūrā. Sagatavošanās braucienam uz ASV ilga trīs gadus: divi gadi bija nepieciešami, lai sagatavotos un nokārtotu ASV eksāmenus medicīnā, bet trešajā gadā tika meklēta rezidentūras vieta. Pēc divām rezidentūrām ASV bija jāatgriežas Latvijā vai arī piecus gadus jāstrādā tādos ASV rajonos, kur trūkst ārstu, un Reinis izvēlējās pēdējo variantu. To noteica viṇa apmaiṇas studenta statuss ar J-1 vīzu: 


\begin{tabular}{|c|c|c|c|c|c|c|c|c|c|c|c|c|}
\hline & 1988 & 1994 & 1995 & 1996 & 1997 & 2000 & 2001 & 2003 & 2004 & 2009 & 2010 & 2019 \\
\hline Mītnes valsts & \multicolumn{4}{|c|}{ LV } & \multicolumn{8}{|c|}{ ASV } \\
\hline $\begin{array}{l}\text { Augsti kvalificēts } \\
\text { vadošs darbs }\end{array}$ & & & & & & & & & & & & \\
\hline $\begin{array}{l}\text { Augsti kvalificēts } \\
\text { algots darbs }\end{array}$ & & & \multicolumn{2}{|c|}{ Rezidentūra LV } & \multicolumn{2}{|c|}{ Rezidentūra ASV } & \multicolumn{2}{|c|}{$\begin{array}{c}\text { Otra rezidentūra } \\
\text { ASV }\end{array}$} & \multicolumn{2}{|c|}{ Darbs ASV } & \multicolumn{2}{|c|}{ Darbs ASV } \\
\hline Mazkvalificēts darb & & & & & & & & & & & & \\
\hline Izglitïba & \multicolumn{2}{|c|}{$\begin{array}{l}\text { Augstākā } \\
\text { izglitīiba } \\
\text { medicīnā LV }\end{array}$} & & & & & & & & & & \\
\hline \multicolumn{13}{|l|}{ Valodas apmācības } \\
\hline \multicolumn{13}{|l|}{$\begin{array}{l}\text { Bezdarbs / darba } \\
\text { meklěšana }\end{array}$} \\
\hline \multicolumn{13}{|l|}{ G̦imenes faktori } \\
\hline $\begin{array}{l}\text { Profesionāla sadar- } \\
\text { bïba ar Latviju }\end{array}$ & & & & & & & & & & & & LĀZA \\
\hline
\end{tabular}

2.7. attēls. Dzīves un darba trajektorijas. 20. Vîrietis, 49 gadi, ārsts, ASV, emigrējis 1997. gadā

“Tur bija milzīga kārpīšanās, jo, kad ir tā J-1 vīza, tas ir dramatisks moments, jo katrs ne vienmēr atrod savu pozīciju. Es būtībā sūtīju pieteikumus visur, kur redzēju, - žurnālos, internetā. [..] Ar to vīzu ir grūti, tur vairums pozīciju nekvalificētos, vai arī darba devējs negribētu ar to noṇemties, jo tas tomēr darba devējam ir liels čakars ar tādu nodarboties.”

Pēc piecu gadu darba ārstu trūkuma rajonos Reinis ir atradis zināmu stabilitāti ārstniecības iestādē ASV Rietumu krastā. Pēdējo gadu laikā Reinis aktīvāk iesaistās Latviešu ārstu un zobārstu apvienības (LĀZA) darbā:

"Noteikti gribētu noderēt Latvijai un kaut kādu sadarbību, bet nu joprojām meklēju, kā varu būt noderīgs Latvijai, protams, savu iespēju robežās.”

Reiņa stāsts ir vēl viens piemērs tam, kā trimdas latviešu atbalsts ir noderējis, lai sagatavotos rezidentūrai ārzemēs. Vienlaikus jānorāda, ka sniegtais atbalsts ir brīnišḳiga iespēja, bet, lai to sekmīgi izmantotu, pašam ir jāpieliek lielas pūles un darbs. Reiņa dzīves pieredze atklāj, ka arī pēc divām rezidentūrām ASV ceḷš nav rozēm kaisīts, ja tavs juridiskais statuss ir apmaiñas students ar J-1 vīzu. Tas ir piemērs, kas parāda, cik būtisks ir juridiskais statuss karjeras procesā, kas salīdzinoši ES/EEZ zonas valstīs ir ievērojami 
labvēlīgāks. Līdzīgi kā daudzos citos gadījumos, Reiṇa sadarbība ar Latviju ir atsākusies un attīstījusies tikai tad, kad viņš pats bija nostabilizējies ASV un kad paralēli tiešajam darbam bija iespējams atrast laiku un motivāciju sadarboties ar Latvijas ārstiem.

\section{AIZBRAUKT LĪDZI UN KḶŪT PAR PROGRAMMĒTĀJU: ANETE}

Anetes ceḷš uz ASV lielā mērā ir saistīts ar vīra ǵimenes lēmumiem. Anetes vīra māte apprecējās ar Amerikas latvieti, 1990. gadā pārcēlās uz ASV un kārtoja dokumentus, lai arī viṇas vienīgais dēls varētu pārcelties. Tā kā dokumentu kārtošana tolaik notika ilgi, Anete tikmēr iepazinās ar savu vīru, apprecējās, un viṇiem piedzima bērns. Drīz pēc tam izrādìjās, ka dokumenti ir nokārtoti un visa gimene var pārcelties uz ASV. Tomēr, ja Anete būtu ḷoti apmierināta ar tām iespējām, kas bija Latvijā, viṇa būtu varējusi palikt, bet tajā brīdī situācija Latvijā nebija apmierinoša:

"1999. gads bija tāds jocīgs laiks, un izglìtība ārzemēs bija tāda prestiža lieta un l̦oti palīdzēja atrast darbu. [..] Es īsti nevarēju atrast īsto vietu, kur studēt, domāju, ka aizbrauksim uz Ameriku, atradīs vietu, izstudēs un brauks atpakaḷ. Vismaz tāda bija tā sākotnējā doma.”

Sākotnējā posmā finansiāli liels atspaids bija iespēja dzīvot pie vīra mātes, kā arī ASV valdības finansiālais atbalsts. Tas l̦āva iegūt bakalaura grādu datorzinātnēs un tālāk jau meklēt darbu kā programmētājai:

"Palīdzēja arī Amerikas valdība. Mēs ar vīru izvēlējāmies lētākās skolas, taču tāpat sañēmām finansiālo atbalstu. Ienākumi no sākuma bija l̦oti zemi, un es nemaksāju neko par savām mācībām. Bija palīdzība, lai grāmatas nopirktu. Spējīgajiem studentiem maksāja stipendijas.”

Jau bakalaura studiju laikā Anete ar studiju biedrenes palīdzību atrada pusslodzes darbu specialitātē - par programmētāju. Pēc bakalaura studijām viṇa kādu laiku strādāja pilnas slodzes darbu, tad piedzima otrs bērns. Pēc tam Anete atrada citu darbu un nolēma atsākt studijas - maǵistrantūras programmā. Anete izvēēējās pakāpenisku mācību procesu, jo bija mazs bērns un darbs, līdz ar to maǵistrantūrā viņa studēja piecus gadus:

“Īstenībā nebija tik traki, jo es magistrantūrā piecus gadus mācījos. Vienā semestrī es tikai vienu klasi ñēmu. [..] Amerikā mācīties ir labi. Ir interesanti, izbaudīju to mācību procesu. Lai gan tas paṇem laiku, tomēr tas dod energiiju, iedvesmu, ieinteresē, un ir azarts to darīt.” 


\begin{tabular}{|c|c|c|c|c|c|c|c|c|c|c|c|c|c|c|c|}
\hline & 1997 & 1998 & 1999 & 2000 & 2002 & 2003 & 2004 & 2009 & 2010 & 2011 & 2012 & 2014 & 2015 & \begin{tabular}{l|l|}
5 & 2017
\end{tabular} & 2019 \\
\hline Mītnes valsts & \multicolumn{2}{|c|}{ LV } & \multicolumn{13}{|c|}{ ASV } \\
\hline \multicolumn{16}{|l|}{$\begin{array}{l}\text { Augsti kvalificēts } \\
\text { vadošs darbs }\end{array}$} \\
\hline $\begin{array}{l}\text { Augsti kvalificēts } \\
\text { algots darbs }\end{array}$ & & & & & & \multicolumn{4}{|c|}{ Darbs ASV } & \multicolumn{3}{|c|}{ Darbs ASV } & \multicolumn{3}{|c|}{ Darbs ASV } \\
\hline $\begin{array}{l}\text { Mazkvalificēts } \\
\text { darbs }\end{array}$ & \multicolumn{2}{|c|}{ Darbs LV } & & & & & & & & & & & & & \\
\hline Izglitîiba & \multicolumn{2}{|c|}{$\begin{array}{l}\text { Uzsāktas } \\
\text { studijas LU }\end{array}$} & & \multicolumn{4}{|c|}{ Bc. (ASV) } & & & & \multicolumn{4}{|c|}{ Mg. (ASV) } & \\
\hline $\begin{array}{l}\text { Valodas ap- } \\
\text { mācíbas }\end{array}$ & & & & & & & & & & & & & & & \\
\hline \multicolumn{16}{|l|}{$\begin{array}{l}\text { Bezdarbs / darba } \\
\text { meklēšana }\end{array}$} \\
\hline Ģimenes faktori & \multicolumn{2}{|c|}{$\begin{array}{c}\text { Laulïbas } \\
\text { un bērna } \\
\text { piedzimšana }\end{array}$} & & & & & & $\begin{array}{c}\text { Otra bērna } \\
\text { piedzimšana }\end{array}$ & & & & & & & \\
\hline $\begin{array}{l}\text { Profesionāla } \\
\text { sadarbïba ar } \\
\text { Latviju }\end{array}$ & & & & & & & & & & & & \multicolumn{4}{|c|}{$\begin{array}{c}\text { Darbojas un vada latvieš } \\
\text { biedribu ASV }\end{array}$} \\
\hline
\end{tabular}

2.8. attēls. Dzīves un darba trajektorijas. 15. Sieviete, 44 gadi, programmētāja, ASV, emigrējusi 1999. gadā

Kopš 2014. gada Anete aktīvi darbojas vietējā latviešu biedrībā, kur sākotnēji iesaistījās, jo abi bērni gāja latviešu skolā, kura rīkoja dažādus pasākumus, arī teātra izrādes, kad viesojās kāds teātris no Latvijas:

"Parasti tur ir vīns un uzkodas pirms tam, un vienu reizi nebija, un es sūdzējos organizatoriem. Organizatori teica: "Mēs veci paliekam, mums tas viss par grūtu, tu vari mums palīdzēt." [..] Tā es lēnā garā iesaistījos, no sākuma tas bija tas teātris, mēs uzñēmām tās viesizrādes. Tagad esam vienīgā organizācija, kas šeit aktīvi darbojas un rīko pasākumus. Rīkojam tās teātra izrādes, esam rīkojuši Jaungada balli, svinības, izstādes, mūzikas koncertus.”

Anetes stāsts parāda, kā jauna sieviete ar bērnu, dodoties līdzi vīram, var sevi apliecināt profesionāli, iegūt bakalaura un maǵistra grādu, strādāt specialitātē un arī audzināt divus bērnus. Anetei būtisks bija gan ğimenes, gan valsts atbalsts, lai iegūtu bakalaura grādu un nostiprinātos profesionālajā dzīvē. Pēc maǵistra grāda iegūšanas un strādājot savā specialitātē jau trešajā darbavietā viṇa atrod laiku arī vadīt latviešu biedrību Amerikā un organizēt dažādus latviešu pasākumus. 
SECINĀJUMI PAR ASV PIEREDZES STĀSTIEM

ASV pieredzes stāstos vienojošais ir tas, ka lēmumu par došanos uz ASV ir veicinājuši latvieši ārzemēs un sākotnējā posmā viṇi ir snieguši savu atbalstu. Tas skaidrojams ar to, ka salīdzinājumā ar Eiropas valstīm ASV ir stingrāks migrācijas režīms attiecībā uz Latviju un vīzai ir nepieciešams skaidrs pamatojums. Būtiski, ka divos no aplūkotajiem gadījumiem došanās uz ASV saistīta ar izglītošanos un profesionālo pilnveidi, un šajā ziṇā nozīmīgs ir bijis trimdas latviešu profesionālais atbalsts. ASV migrācijas režīma ietekme spilgti atklājas emigrējušā ārsta pieredzē, kas parāda, ka pēc rezidentūras ASV nebūt nav tik viegli atrast pastāvīgu ārsta vietu, ja jānnem vērā J-1 vīzas nosacījumi. Divos citos stāstos savukārt atklājas gimenes un attiecību saišu nozīme migrācijas lēmumos. Vienā gadījumā ǵimenes saites motivēja atgriezties Latvijā, bet otrā gadījumā tās motivēja doties prom no Latvijas, jo vīrs un vīra vecāki pārcēlās uz ASV. Šajos stāstos redzams, kā veidojas sekmīga ārsta un programmētājas karjera atšḳirīgās ASV vietās un kā ASV iegūtā izglītība paver iespējas arī akadēmiskai karjerai Latvijā.

\subsection{VĀCIJAS PIEREDZES STĀSTI}

IT SPECIĀLISTES KARJERA VĀCIJĀ: ALISE

Alise aizbrauca uz Vāciju 2004. gadā iegūt augstāko izglītību IT biznesa jomā. Augstākās izglītības iespējas Vācijā Alisei likās pieejamākas nekā Latvijā, jo studijas Vācijā ir bez maksas. Vācija kā vieta, kur iegūt izglītîbu, tika izvēlēta tādēḷ, ka tur dzīvoja brālēns, kurš sākumā palīdzēja iekārtoties:

“1999.-2000. gadi. Latvijā bija haoss ar tām mācībām. Man tas bija arī naudas jautājums. Jo universitātes mācību maksa Latvijā bija l̦oti augsta, man vajadzētu ņemt kredītu. Bet Vācijā ir par brīvu. Vācijā mācības man maksāja 150 EUR par semestri, vajadzēja vēl tikai izdzīvošanas naudu. Tas bija iemesls, kādēl atbraucu uz Vāciju. Tā kā man bija brālēns Vācijā, tāpēc es braucu uz Vāciju paprovēt, vai tas izdosies.”

Četrus gadus piektdienās, sestdienās un svētdienās Alise strādāja restorānā, vēlāk nepilnu slodzi universitātē. Dzīvojot kopmītnē, ar nopelnīto algu varēja iztikt:

"Tā es tos 4-5 gadus pa darbu un mācībām skraidīju. Jā, bija grūti, bet, ja cenšas, ja labi saorganizē to laika menedžmentu, tad var visu noorganizêt. 
Protams, vajadzēja strādāt pa Ziemassvētkiem, un universitātē strādāju. Bet darbus ar mācībām varēja apvienot.”

Pirmo gadu Vācijā Alise mācījās vācu valodu, jo sākotnēji vācu valodas zināšanu viņai nebija. Vācu valodu Alise apguva Tautas skolā, kur arī nokārtoja valodas pārbaudes eksāmenus:

"Es gāju "Volksschule”. Nobeidzu kursus. Vēl piestrādāju. Daudz ar vāciešiem runāju. L,oti daudz valodu mācījos. Gada laikā es iemācījos. Lai tiktu universitātē, ir jānoliek eksāmens. Eksāmens ir divas dienas. Viena diena ir runāšana, otrā diena ir četras stundas - gramatika, saprašana, klausǐšanās, testi. Lai to eksāmenu es noliktu, es gadu mācījos. Es atbraucu bez zināšanām. L̦oti intensīvi mācījos. Arī tāds smags posms. Bet, ja dzīvo šeit, tad var iemācīties.”

Ar darba meklēšanu specialitātē Alise pirmo reizi Vācijā saskārās, meklējot prakses vietu studiju laikā. Lai atrastu prakses vietu, ir jāzina, kur vēlies strādāt, un aktīvi jāraksta pieteikuma vēstules internetā. Pēc universitātes beigšanas Alise līdzīgi meklēja arī savu pirmo pastāvīgo darbavietu specialitātē. Šajā laikā Alise izsūtīja 60-70 CV un devās uz daudzām intervijām klātienē:

"Viss sākās ar praksi. Universitātē vajadzēja meklēt prakses vietu. Piesēdos pie interneta un meklēju. Salīdzinot ar Latvijas websaitiem, Vācijā ir viss skaidrs, kur un kādus darbiniekus meklē. Aiziet uz jebkura uzṇēmuma lappusi, l̦oti ātri var visu atrast. Es skatījos arī pēc regiona, jo piektdien, sestdien, svētdien man vajadzēja strādāt restorānā. Es skatījos, kādas firmas ir tur, kur mācījos. Rakstīju CV, un tā arī caur internetu atradu. Pēc universitātes beigšanas es apsēdos un izdomāju, uz kādu pilsētu es braukšu, es nolēmu uz Berlīni, jo Berlīne ir liela, internacionāla, ar startapiem. Tad vienkārši sūtīju savus CV, man liekas, kādus 60-70 CV izsūtīju. Man bija daudz arī pārrunas. [..] Visa tā meklēšana ir caur internetu. Vienkārši vajag zināt, kādā jomā es vēlos, un meklēt, meklēt, meklēt."

Piecu gadu laikā Alise bija sevi pierādījusi kā labu darbinieci un izveidojusi kontaktu tīklu Berlīnē, un tad jau viņai pašai darbs vairs nebija aktīvi jāmeklē, bet viṇa saṇēma darba piedāvājumus:

"Es Berlīnē esmu 6-7 gadus, un man ir izveidojies savs tīkls. Man tagad vairs darbu meklēt nevajag, tagad man to piedāvā. No sākuma pašam bija 


\begin{tabular}{|c|c|c|c|c|c|c|c|c|c|c|c|}
\hline & 1999 & 2002 & 2004 & 2005 & 2007 & 2011 & 2012 & 2015 & 2016 & 2018 & 2019 \\
\hline Mītnes valsts & \multicolumn{2}{|c|}{ LV } & \multicolumn{9}{|c|}{ Vâcija (DE) } \\
\hline \multicolumn{12}{|l|}{$\begin{array}{l}\text { Augsti kvalificēts vadošs } \\
\text { darbs }\end{array}$} \\
\hline $\begin{array}{l}\text { Augsti kvalificēts algots } \\
\text { darbs }\end{array}$ & & & & & & \multicolumn{3}{|c|}{ Darbs DE } & \multicolumn{3}{|c|}{ Darbs DE } \\
\hline Mazkvalificēts darbs & & & \multicolumn{4}{|c|}{ Darbs DE } & & & & & \\
\hline Izglitïba & \multicolumn{2}{|c|}{$\begin{array}{l}\text { Profesionālā } \\
\text { izglitîba }\end{array}$} & & & \multicolumn{2}{|c|}{ Bc. (DE) } & \multicolumn{2}{|c|}{ Mg. (DE) } & & & \\
\hline \multicolumn{12}{|l|}{ Valodas apmācības } \\
\hline \multicolumn{12}{|l|}{$\begin{array}{l}\text { Bezdarbs / darba } \\
\text { meklěšana }\end{array}$} \\
\hline Ģimenes faktori & & & & & & & & & & $\begin{array}{c}\text { Bērna } \\
\text { piedzimšana }\end{array}$ & \\
\hline $\begin{array}{l}\text { Profesionāla sadarbïba ar } \\
\text { Latviju }\end{array}$ & & & & & & & & & & & \\
\hline
\end{tabular}

2.9. attēls. Dzīves un darba trajektorijas. 21. Sieviete, 39 gadi, IT speciāliste, Vācija, emigrējusi 2004. gadā

jāmeklē, kamēer izveido savu tīklu, sakarus. Šajā uzṇēmumā man piedāvāja strādāt, labāku algu un labāku perspektīvu. Trīs gadus jau strādāju.”

2018. gadā Alisei piedzima bērniņš, bet tas būtiski netraucē darba pienākumiem, jo konkrētajā darbavietā ir iespēja strādāt un vadīt IT projektus no mājām. Izvērtējot savu karjeras veidošanas pieredzi, Alise atzīst, ka Vācijā vadošos darbos lielākas iespējas atrast darbu ir tiem, kas augstāko izglîtību ir ieguvuši Vācijā:

“Vācijā labāk pieñem tos, kas Vācijā ir mācījušies. Ja nāk ar Latvijas diplomu, tad tas ir atkarīgs no specialitātes. Tīri programmēšanā skatās uz pieredzi. Ja nāk uz plānošanu, projekta vadību, tad svarīga arī Vācijas pieredze un Vācijas izglītība. Jo viṇi domā, ka Vācijā ir labākā izglìtība Eiropā.”

Alise arī vēlas sniegt savas zināšanas interesentiem Latvijā, jo viṇa redz, ka Latvijā daudziem ir interese, bet trūkst zināšanu, kā izstrādāt IT produktus. Tomēr pagaidām iecere organizēt zināšanu apmaiṇas seminārus ir apstājusies, jo Alise nav pārliecināta, kā to labāk darīt:

"Pirms pāris gadiem es vēlējos organizēt zināšanu apmaiṇu. Es gribēju taisīt dienas seminārus, kur notiktu zināšanu apmain,a, kur es varētu stāstīt par savu Vācijas pieredzi. Bet es nezinu, kur griezties, lai to organizētu. Es 
redzēju, ka cilvēki mēgina kaut ko "e-commerce", bet viṇiem pietrūkst to zināšanu. Palīdzēt viniiem ar zināšanām. Kur to sākt?”

Rezumējot Alises stāstu, redzams, ka sievietes no Latvijas var loti sekmīgi attīstīt karjeru IT jomā, bet zināma priekšrocība viṇas gadījumā ir tā, ka izglìtība specialitātē iegūta Vācijā. Vienlaikus viṇas pirmā pieredze, dzīvojot Vācijā, ir vērtējama kā diezgan komplicēta un ne pārāk viegla. Alise pirmo gadu mācījās vācu valodu un kārtoja vācu valodas eksāmenu, bet pēc tam studiju laikā strādāja mazkvalificētu darbu, lai samaksātu îri un citus iztikas izdevumus.

\section{KĀ KLŪTT PAR AUGSTA LITMEN̦A ĀRSTU: EDGARS}

Edgars ir viens no jaunajiem ārstiem, kas nepietiekamā vietu skaita dēl rezidentūrā Latvijā pieteicās uz rezidentūras vietu Vācijā. Viṇa intereses jau bērnībā bija saistītas ar ārsta profesiju, un studiju laikā Rīgā viṇš strādāja par sanitāru slimnīcā Rīgā, kur sākotnēji bija cerējis strādāt arī pēc izglītības iegūšanas. Diemžēl tajā gadā, kad Edgars beidza medicīnas studijas, rezidentūrā viņa izvēlētajā specialitātē bija tikai viena vieta, uz kuru viṇš netika:

"Latvijā es iesniedzu dokumentus uz rezidentūru, bet tur tajā gadā bija tikai viena vieta, un es paliku uzreiz aiz strīpas. Tajā pašā dienā, kad saṇēmu ziṇu par to, ka neesmu ticis, es iesniedzu arī dokumentus Vācijā. [..] Vispirms mani uzaicināja, lai atbraucu aprunāties. Tad es aizbraucu, un šefs novērtēja manu motivāciju un teica: "Labi. Brauksi pie mums strādāt."”

Izvēle par labu Vācijai saistījās ar vairākiem faktoriem. Pirmkārt, Edgars jau studiju laikā bija bijis praksē Vācijā. Otrkārt, viṇa specialitātē vācu valodā bija nozīmīgas publikācijas, arī viņš pats savas publikācijas gatavoja vāciski, tādēḷ pēdējo divu gadu laikā Rīgā bija pastiprināti mācījies vācu valodu. Tomēr sākums rezidentūrā Vācijas slimnīcā bija l̦oti grūts. N̦emot vērā, ka Edgars ir pret sevi ḷoti prasīgs, viṇš daudz strādāja, jo viṇam likās, ka netiek galā tik labi, kā gribētos. Runājot ar pacientiem, sākumā bija grūti izteikties, trūka vārdu. Līdz ar to pirmajā posmā bija sevi jāpārvar, lai neatmestu visam ar roku un tomēr paliktu Vācijā:

"Man sākumā nekas nepatika. Man nepatika pilsēta, man nepatika cilvēki, man nepatika, ka ir tik daudz jārunā. Bet tad es to pien̄ēmu.”

Tagad Edgars saista savu nākotni ar to pašu slimnīcu, kurā izgāja rezidentūru, jo tā viṇa specialitātē ir viena no labākajām slimnīcām Vācijā un piedāvā 


\begin{tabular}{|c|c|c|c|c|c|c|c|c|c|}
\hline & 2006 & 2008 & 2009 & 2011 & 2012 & 2015 & 2016 & 2018 & 2019 \\
\hline Mītnes valsts & \multicolumn{4}{|c|}{ LV } & \multicolumn{5}{|c|}{ Vâcija (DE) } \\
\hline \multicolumn{10}{|l|}{ Augsti kvalificēts vadošs darbs } \\
\hline Augsti kvalificēts algots darbs & & & & & \multicolumn{2}{|c|}{ Rezidentūra DE } & \multicolumn{2}{|c|}{ Darbs DE } & Darbs DE \\
\hline Mazkvalificēts darbs & & & \multicolumn{2}{|c|}{ Darbs LV } & & & & & \\
\hline Izglitīiba & \multicolumn{4}{|c|}{ Augstākā izglitīiba medicīnā LV } & & & & & \\
\hline \multicolumn{10}{|l|}{ Valodas apmācības } \\
\hline \multicolumn{10}{|l|}{ Bezdarbs / darba meklēšana } \\
\hline \multicolumn{10}{|l|}{ G̦imenes faktori } \\
\hline Profesionāla sadarbība ar Latviju & & & & & & & & & \\
\hline
\end{tabular}

2.10. attēls. Dzīves un darba trajektorijas. 29. Virietis, 32 gadi, ārsts, Vācija, emigrējis 2012. gadā

interesantas izaugsmes iespējas. Vācijā Edgars ir atradis arī draudzeni un atgriezties Latvijā neplāno:

“Jā, es gribētu te palikt. Man raksturīgs, ka man gribas visu laiku kādu izaugsmi, pilnveidoties, un to es vislabāk varu darīt šeit. Šì slimnīca ir augsta līmeña slimnīca, kas man vislabāk var nodrošināt profesionālās izaugsmes iespējas. Aizejot uz citu, parasto slimnīcu, tā būtu apstāšanās, atkrišana atpakal,.”

Edgara stāsts šajā pētījumā ir nozīmīgs ar to, ka viṇa aizbraukšanas galvenais iemesls bija rezidentūras vietu trūkums Latvijā. Pēc rezidentūras augsta līmeṇa slimnīcā Vācijā, kur spējis apliecināt sevi kā labu speciālistu, atgriešanās Latvijā viņu pagaidām neinteresē. Profesionālās karjeras izaugsmes ziṇā Edgars ir atradis vienu no pasaulē labākajām slimnīcām, kurā strādāt. Pēc ciemošanās pie vecākiem Latvijā viņš Vācijā atgriežas jau kā mājās.

\section{ZINĀTNIEKA CEL̦Š UZ VĀCIJU UN ATGRIEŠANĀS LATVIJĀ: G̣IRTS}

Ģirts bakalaura, maǵistra un arī doktora zinātnisko grādu fizikā ir ieguvis Latvijā. Pēc doktora grāda iegūšanas 2002. gadā Latvijas zinātnē nebija interesantu projektu, kuros piedalīties, tādēḷ Ģirts nolēma meklēt pēcdoktorantūras vietu ārvalstīs. Pirms tam sadarbojoties ar Zviedrijas fiziķiem, Ģirta pētnieciskā tēma bija tuva kāda zinātnieka tēmai Maksa Planka Kvantu optikas institūtā Vācijā, un viņš tika uzaicināts uz turieni kā pēcdoktorantūras pētnieks. Pēc gada šim zinātniekam tika piešķirta Nobela prēmija fizikā, un pētniecība pie viṇa kḷuva ļoti prestiža. Tas Ģirtam atviegloja iespējas uzvarēt 
Marijas Sklodovskas-Kirī individuālo stipendiju konkursā starptautiskajiem pētniekiem un turpināt strādāt Vācijā, bet viņam bija iespēja stažēties arī ASV. Šajā laikā Ģirts tika iesaistīts arī projektā prestižajā Šveices Federālajā tehnoloǵiju institūtā Cīrihē un Eiropas Kodolpētījumu organizācijā CERN. Kopumā šis periods G̣irtam saistās ar intensīvu starptautisko sadarbību:

"Kādus trīs profesorus izvēlējos (kur pieteikties pēcdoktorantūrā). Viens variants bija Cīrihe. Cīrihes profesors teica, ka viņam nav šobrīd vietas. Otrs bija Minhenē. Profesors mani pien,ēma, jo viṇš bija lasījis manu darbu, kas bija ar Lundas Universitāti. Tā tēma bija nedaudz līdzīga. [..] Pēc gada profesoram piešḳìra Nobela prēmiju. Tad jau uz viṇa grupu vairs tā nevarēja tikt, jo bija l̦oti daudz pieteikumu. Paveicās, ka gadu iepriekš pieteicos. No Minhenes mani vēl aizsūtīja pastažēties uz ASV. Es arī doktorantūras laikā biju ASV, Oklahomas Universitātē. Tagad mani aizsūtīja pamācīties uz Boldēru un ieviest tehnoloǵiju Eiropā par lāzeru stabilizēšanu. To tehnoloǵiju mēs Vācijā attīstījām.”

Arī prombūtnes gados Ģirts uzturēja kontaktus ar pētniekiem Latvijā, uzstājās ar lekcijām Rīgā semināros un konferencēs, kā arī piedalījās projektu sagatavošanā. Pateicoties projektam, ko Latvija saṇēma zinātniskā līmeṇa celšanai, Ģirtam bija iespēja atgriezties Latvijā un izveidot savu laboratoriju, ko viņš arī darīja:

"Bija iespēja beidzot izveidot savu laboratoriju. Par pusmiljonu sapirkt lāzerus. Man arī likās, ka pietiek strādāt priekš citiem, vajag pašam kaut ko savu darìt. Tā bija tāda iespēja. Mamma arī jau bija gados un teica, ka gribētu, lai es atgriežos atpakal Latvijā. Veselība vairs nav tik laba, ziemā grūti uz veikalu aiziet, slidens. Tā bija iespēja atgriezties Latvijā. Pa Vācijas gadiem bija sakrāta nauda dzīvoklim."

Pēc atgriešanās Latvijā Ģirts ar kolēgiiem sekmīgi piesaistīja vairāku ES fondu projektu finansējumu un kopumā ar savu zinātnisko karjeru un iespējām ir apmierināts:

"Darbs ir, un nauda ir tikpat liela kā Vācijā strādājot. Pēc algas nav motivācijas braukt kaut kur projām. Bet ir l̦oti labi, ja var uz kādu mēnesi gadā aizbraukt pie kolēgiem uz ārzemēm. Pamērìt kaut ko uz vinu aparatūras, tad var daudz publikācijas pa gadu uzǵenerēt. Ja ir līdzautors dažādām grupām.” 


\begin{tabular}{|c|c|c|c|c|c|c|c|c|c|c|c|c|c|c|c|}
\hline & 1992 & 1996 & 1997 & 1998 & 2000 & 2002 & 2003 & 2004 & 2005 & 2006 & |2007| & 2010 & 2012 & \multirow{2}{*}{\begin{tabular}{|r|}
2013 \\
\end{tabular}} & 2019 \\
\hline Mītnes valsts & \multicolumn{7}{|c|}{ LV } & \multicolumn{6}{|c|}{ Vācija (DE) } & & \\
\hline $\begin{array}{l}\text { Augsti kvalificēts } \\
\text { vadošs darbs }\end{array}$ & & & & & & & & & & & & & & \multicolumn{2}{|c|}{ Darbs LV } \\
\hline $\begin{array}{l}\text { Augsti kvalificēts algots } \\
\text { darbs }\end{array}$ & & & \multicolumn{3}{|c|}{$\begin{array}{l}\text { Darbs LV un } \\
\text { Zviedrijā }\end{array}$} & Dark & DS LV & \multicolumn{3}{|c|}{\begin{tabular}{|c|} 
Postdoktorantūra \\
$\mathrm{DE}$
\end{tabular}} & \multicolumn{2}{|c|}{ Darbs DE } & $\begin{array}{l}\text { Darbs DE } \\
\text { un Šveicē }\end{array}$ & & \\
\hline Mazkvalificēts darbs & & & & & & & & & & & & & & & \\
\hline Izglitīiba & \multicolumn{2}{|c|}{ Bc. (LV) } & \multicolumn{2}{|c|}{ Mg. (LV) } & \multicolumn{2}{|c|}{ Dr. (LV) } & & & & & & & & & \\
\hline Valodas apmācības & & & & & & & & & & & & & & & \\
\hline $\begin{array}{l}\text { Bezdarbs / darba } \\
\text { meklēšana }\end{array}$ & & & & & & & & & & & & & & & \\
\hline G̦imenes faktori & & & & & & & & & & & & & $\begin{array}{l}\text { Mātes ves } \\
\text { pasliktinā }\end{array}$ & selïbas & \\
\hline $\begin{array}{l}\text { Profesionāla sadarbība } \\
\text { ar Latviju }\end{array}$ & & & & & & & & \multicolumn{6}{|c|}{ Pastāvīga sadarbība ar kolēǵiem Latvijā } & & \\
\hline
\end{tabular}

2.11. attēls. Dzīves un darba trajektorijas. 28. Vĩrietis, 46 gadi, zinātnieks, Vācija, emigrējis 2004. gadā, atgriezies 2013. gadā

Kopumā Ģirta piemērs atklāj, ka pēc veiksmīgas pēcdoktorantūras ir iespējas strādāt interesantu darbu pasaules prestižākajās zinātnes institūcijās. Savukārt lēmumu atgriezties Latvijā, kur zinātniskās pētniecības iespējas ir salīdzinoši mazākas, sekmēja divi faktori. Pirmkārt, pieejamais finansējums laboratorijas izveidei Latvijā un iespēja uzsākt savus pētījumus. Otrkārt, nepieciešamība atbalstīt māti un viņas lūgums atgriezties Latvijā. Ģirta stāsts ir arī veiksmes piemērs par atgriešanos Latvijā, jo iegūtās zināšanas tiek izmantotas gan darbā Latvijas laboratorijā, gan turpinot sadarbību ar universitātēm, kurās pētījumi veikti iepriekš.

\section{SECINĀJUMI PAR VĀCIJAS PIEREDZES STĀSTIEM}

Trīs pieredzes stāsti par Latvijas emigrantiem Vācijā atklāj IT speciālista, ārsta un fiziķa pieredzi. Visos šajos gadījumos aizbraukšana no Latvijas ir saistīta ar vilšanos iespējās, ko piedāvāja Latvija, lai gan aizbraukšanas gadi ir atšķirīgi. Visiem trim emigrantiem karjeras attīstība Vācijā ir ḷoti sekmīga, lai gan aizbraucēju izglītības līmenis atšķiras. IT speciāliste augstāko izglîtību gan bakalaura, gan maǵistra līmenī ieguva tikai Vācijā, taču ārsts pamata izglītību bija ieguvis Latvijā un tikai rezidentūras līmenī pabeidza Vācijā, bet fiziḳis izglītību līdz pat doktora grādam ieguva Latvijā, savukārt ārvalstīs notika stažěšanās un pētnieciskā darbība. Vācijas darba tirgus konkrētajiem augsti kvalificētajiem Latvijas speciālistiem ir bijis atvērts, bet iekḷaušanās 
tajā ir saistīta ar papildu ieguldījumiem vācu valodas apguvē un l̦oti augstu darba intensitāti sākotnējā darba posmā (IT speciālistes un ārsta gadījums).

\subsection{NORVĒG̣IJAS PIEREDZES STĀSTI}

SPORTS UN KARJERA: ANDRIS

Andri uz Norvēǵiju aizveda sporta trenera darbs vasaras nometnēs. Viens no sporta klubiem meklēja pastāvīgu treneri, un Andris pieteicās uz trenera vietu, jo viṇam šāds piedāvājums šķita interesants un likās - kāpēc nepamēǵināt:

“Tas bija 2011. gads, un bija iestājusies kaut kāda rutīna Latvijā. Biju vairākas reizes Norvēǵijā uz nometnēm palīdzēt tur kā spēlētājs, sparings. Mans iepriekšējais treneris, latvietis, arī tur bija. Bija viens klubs, kas meklēja treneri. Tad es pieteicos un biju ar mieru pārcelties. Kamēr jauns, domāju, ka jāizmanto iespējas gūt pieredzi. Jauna valoda, vispār dzīves pieredze. Protams, arī Norvēgeijas augstais labklājības līmenis. Domāju arī uzkrāt kādu starta kapitālu nākamajai dzīvei. Tā arī devos."

Andra gadījumā būtiski uzsvērt, ka iespējas braukt uz Norvēǵijas sporta nometnēm viņam sākotnēji piedāvāja viṇa bijušais treneris, kurš dzīvoja un strādāja Norvēǵijā. Līdz ar to var teikt, ka uz Norvēǵiju viṇu aizveda sports un iepriekšējie kontakti. Andris sāka strādāt sporta klubā, kura īpašnieks pal̄̄dzēja viṇam nokārtot iespēju mācīties norvēǵu valodu viengadīgā programmā tas apvienojumā ar ikdienas praksi l̦āva gada laikā apgūt norvēǵu valodu. Profesionālais pavērsiens strādāt kā finansistam-grāmatvedim Andrim atnāca interesantu sakritību rezultātā. Latvijā Andris jau bija ieguvis bakalaura grādu finansēs, bet profesionālās pieredzes nebija. Vienlaikus viṇa nākamais darba devējs piedāvāja Andrim strādāt citā klubā par treneri nepilnu slodzi un iespēju strādāt norvēǵu grāmatvedības uzṇēmumā. Pats Andris uzskata, ka šādu iespēju viṇam piedāvāja, jo viṇš bija labi sevi parādījis un mācēja norvēǵu valodu:

"Pamatojoties uz mana darba rezultātiem, attieksmi, prasmēm, tai skaitā valodas prasmēm, mentalitātes izpratni. L,oti liela nozīme ir tam, ka tu mentāli iekḷaujies tai sabiedrībā, kur tu dzīvo. Tas mans nākamais šefs, kurš man deva to iespēju par grāmatvedi strādāt, mani uzaicināja. Jo tajā brīdī es jau taisījos braukt prom uz citu pilsētu, bet viṇi piedāvāja palikt. Ja tu nāc pie 
manis strādāt par grāmatvedi, tad tu man palīdzēsi kā treneris trīs reizes nedēlāa . Man bija arī izglìtība no Banku augstskolas, un viṇi piedāvāja man darbu grāmatvedībā. Bartera situācija. Es viṇam palīdzu, un viṇš man. Un tas joprojām turpinās.”

Pirmais gads grāmatvedības uzṇēmumā Andrim pagāja, mācoties un apgūstot grāmatvedības īpatnības Norvēǵijā. Pēc mācekḷa perioda, kḷūstot par patstāvīgu speciālistu, Andrim sāka veidoties latviešu klientu loks, kuri labprāt izmantoja iespēju Norvēǵijas grāmatvedības jautājumus apspriest latviski:

"Gan sapratne, gan specifiskā terminologija. Viss tas bija jāapgūst. Pamazām to apgūstot, viss iestrādājās. Sāka veidoties latviešu klientu portfelis. Daudzi latvieši tur nodarbojas ar visādām lietām, kur arī šādi pakalpojumi nepieciešami, pārsvarā jau būvniecībā. Tad jau logiiski veidojas tā saikne grāmatvedības un konsultāciju jautājumus pārrunāt un risināt dzimtajā mēle."”

Andra klientu lokā ir gan latvieši, kas nodibinājuši savu uzṇēmumu Norvēgiijā, gan latvieši, kas strādā kā pašnodarbinātie, gan arī uzṇēmumi, kas dibināti Latvijā, bet savas preces vai pakalpojumus piedāvā Norvēgijā. Izveidotais klientu portfelis arī l̦āva ar uzṇēmuma vadību vienoties par attālinātu darbu, un 2018. gadā Andris atgriezās Latvijā, lai turpinātu darīt to pašu, ko Norvēǵijā, bet dzīvojot Latvijā. Darba tikšanos dēḷ Andris dažas reizes ceturksnī dodas uz Norvēgeiju, bet pārējo ir iespējams veikt attālināti:

"Sākumā man bija norvēǵu klienti, ko man firma iedeva. Un tad laika gaitā es to savu portfeli izveidoju, un norvēgu klientus atdeva kolēgiem. Uz šī pamata es varēju ar priekšniecību runāt, ka vēlos atgriezties un ka ikdienas darbā nekas nemainītos, tikai vēl turpinātu strādāt pie klientūras palielināšanas. [..] Tas, manuprāt, rada šo "win-win" situāciju, tāpēc arī bija š̄ doma un ideja. Pašiem bija vēlme atgriezties mājās un ar to iegūto pieredzi un zināšanām dzīvot un strādāt Latvijā."

Atgriešanos Latvijā veicināja arī Andra ǵimenes situācija, jo viņam ir divi mazi bērni, un viṇš vēlas, lai tie uzaug Latvijā. Kopumā Andra stāsts atklāj, kā sports palīdz iegūt kontaktus un iespējas citās valstīs un vēlāk izveidot savu biznesu, kas balstīts uz divu valstu ekonomiskajām saitēm. Iegūtā pieredze un Norvēgijas situācija darba tirgū un biznesā, kur salīdzinoši daudzi latvieši strādā vai sniedz pakalpojumus kā uzṇēmēji, paver iespējas attīstît grāmatvedības pakalpojumus, kas ir pieprasīti konkrētajā segmentā. No kultūras 


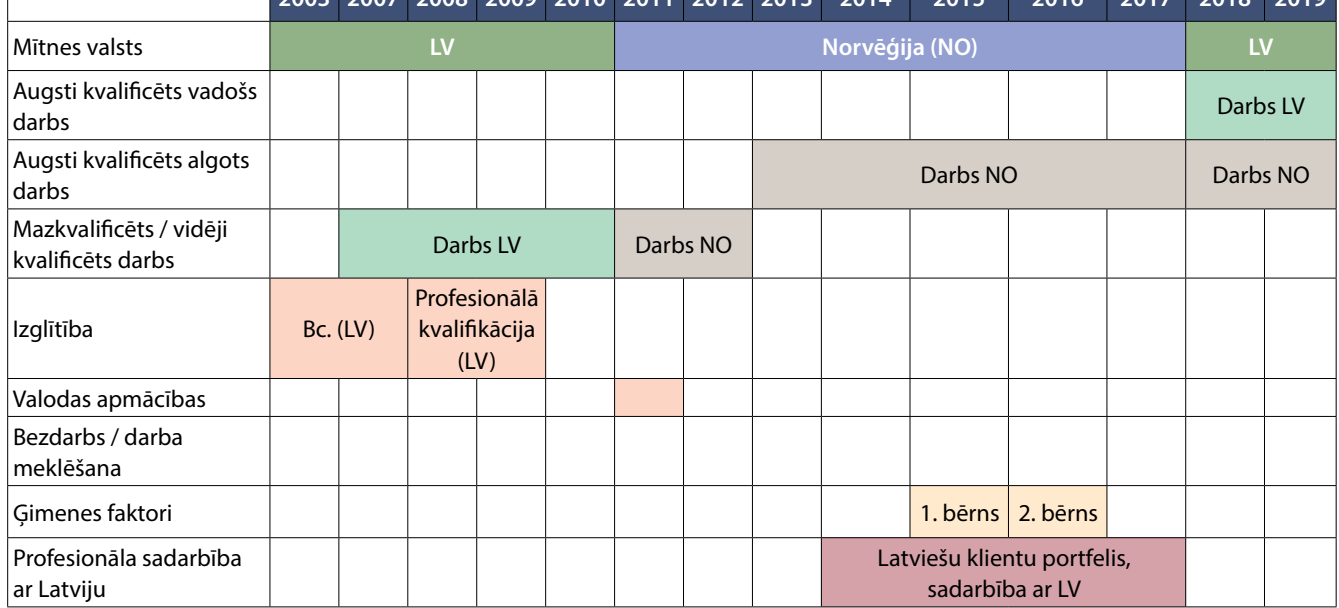

2.12. attēls. Dzīves un darba trajektorijas. 31. Virietis, 35 gadi, finansists-grāmatvedis, Norvēǵija, emigrējis 2011. gadā, atgriezies 2018. gadā

kapitāla pārneses perspektīvas Andra stāsts atklāj, kā Latvijā iegūtais kultūras kapitāls (valoda un lokālo īpatnību zināšanas) un Norvēǵijā iegūtās profesionālās zināšanas var tikt izmantotas sinerǵijā - sniedzot grāmatvedības pakalpojumus latviešiem Norvēǵijā.

\section{IT SPECIĀLISTA PIEREDZE UN SVĀRSTMIGRĀCIJA: ZIGURDS}

Zigurda starptautiskā pieredze veidojās, strādājot starptautiskā uzṇēmumā, kas sniedz IT risinājumu pakalpojumus. Viṇam bieži nācās ceḷot, jo pakalpojumi nereti bija jāsniedz ārpus Latvijas. Pēc septiṇu gadu darba šajā uzṇēmumā - pamatā dzīvojot Latvijā, bet daudz braukājot - viṇam radās izdevība iesaistīties projektā, kur ilgāku laiku bija jādzīvo Norvēǵijā. Arī šajā gadījumā sākotnēji uz pusgadu paredzētais projekts visu laiku tika pagarināts:

“Tas bija kā projekts. Es strādāju starptautiskā uzṇēmumā, man vienkārši piedāvāja tur pastrādāt. Jaunu sistēmu ieviešana. Tad es aizbraucu uz Norvēǵiju uz pusgadu, pagarināju uz gadu, pagarināju uz pusotru gadu, pagarināju vēl uz diviem gadiem. To sistēmu ieviesa, tad to sistēmu vajadzēja uzturēt, kādam atbildēt un saprast."

Dzīvojot Norvēǵijā, Zigurds izstrādāja tādu darba modeli, ka divas nedēḷas viṇš strādā birojā Norvēǵijā, bet divas nedēḷas - Latvijā. Diemžēl darba 
devēju tas īsti neapmierināja, tādēḷ Zigurds atrada Oslo citu darba devēju, kuru pilnībā apmierina situācija, ka dạ̣a darba laika tiek pavadīta Latvijā, jo galvenais ir sasniegtais rezultāts:

“Šobrīd skaitās, ka es strādāju Norvēgijā, bet es uzturos nedēḷ šeit, nedēḷ tur. Tas stāsts bija tāds, ka kaut kādā brīdī es sapratu, ka mājās ir vislabāk. Es biju iekārtojies, ka es divas nedēḷas dzīvoju tur, divas šeit, bet tiem vieniem darba devējiem tas vairs īsti nepatika. Tur ir diezgan formāla kompānija, un, ka tu divas nedēlas neesi ofisā un strādā mājās, kur neviens neredz, tas viniem nepatika. Tad pie tiem es beidzu un pārgāju pie citiem darba devējiem, kuriem tas pilnīgi apmierina un ir svarīgi, ka ir izdarīts. Es darbojos no Rīgas, bet, lai nepazaudētu kontaktus ar cilvēkiem, aizbraucu uz turieni."”

Ar pašreizējo darba modeli Zigurds ir pilnībā apmierināts, jo viṇam nav intereses veidot ciešākas saites ar Norvēǵiju un iekḷauties Norvēḡijas sabiedrībā, bet darbs Norvēgijā dod iespēju labi pelnīt un sakrāt sev labu pensiju. Arī braukāt uz Norvēǵiju viṇam šķiet ievērojami ērtāk nekā braukāt, piemēram, uz Kazahstānu, tādēḷ par laiku, kas pavadīts ceḷā uz darbu, Zigurds nesūdzas:

“Nedēḷu tur, nedēḷ šeit. Pa vīkendiem lidoju. No rìta celies puspiecos Rīgā, devin,os ofisā sāc strādāt Oslo. Attāluma ziṇā tas ir tuvāk nekā viniem pašiem norvēgu kaut kādas tālākās vietas. [..] Es [juridiski] skaitos tur, no Latvijas es skaitos darba attiecībās tur, es maksāju nodokḷus Norvēgiijā,

\begin{tabular}{|c|c|c|c|c|c|c|c|c|c|c|c|c|c|c|c|}
\hline & $\mid 1992$ & 1996 & 1999 & 2001 & 2002 & 2004 & 2006 & 2008 & 2009 & 2010 & 2011 & 2012 & 2013 & \multirow{2}{*}{\multicolumn{2}{|c|}{\begin{tabular}{|c|c|c|}
2014 & 2019 \\
LV
\end{tabular}}} \\
\hline Mītnes valsts & \multicolumn{9}{|c|}{ LV } & \multicolumn{4}{|c|}{ Norvēǵija (NO) } & & \\
\hline \multicolumn{16}{|l|}{$\begin{array}{l}\text { Augsti kvalificēts vadošs } \\
\text { darbs }\end{array}$} \\
\hline $\begin{array}{l}\text { Augsti kvalificēts algots } \\
\text { darbs }\end{array}$ & & \multicolumn{3}{|c|}{ Darbs (LV) } & \multicolumn{5}{|c|}{$\begin{array}{c}\text { Darbs starptautiskā uzñèmumā, } \\
\text { daudz komandējumu }\end{array}$} & \multicolumn{4}{|c|}{ Darbs NO } & \multicolumn{2}{|c|}{ Darbs NO } \\
\hline $\begin{array}{l}\text { Mazkvalificēts / vidēji } \\
\text { kvalificēts darbs }\end{array}$ & & & & & & & & & & & & & & & \\
\hline Izglìtība & \multicolumn{2}{|c|}{ Bc. (LV) } & \multicolumn{2}{|c|}{ Mg. (LV) } & & & & & & & & & & & \\
\hline Valodas apmācības & & & & & & & & & & & & & & & \\
\hline Bezdarbs / darba meklēšan & & & & & & & & & & & & & & & \\
\hline Ģimenes faktori & & & & & & & & & & & & & & & \\
\hline $\begin{array}{l}\text { Profesionāla sadarbïba ar } \\
\text { Latviju }\end{array}$ & & & & & & & & & & & & & & & \\
\hline
\end{tabular}

2.13. attēls. Dzīves un darba trajektorijas. 35. Vîrietis, 52 gadi, IT, Norvēǵija, emigrējis 2010. gadā, atgriezies 2013. gadā 
krāju pensijai Norvēgijā, bet es sevi mierinu ar domu, ka es esmu Latvijas eksporta prece, jo to naudu, ko es nopelnu tur, es to notērēju šeit. Es atvedu tos tūkstošus uz šejieni.”

Kopumā Zigurda stāsts ir interesants svārstmigrācijas gadījums, kas ir mērḳtiecīgi izvēlēts un atbilst konkrētā indivīda prasībām. Viṇa pieredze atklāj, ka labs speciālists Norvēǵijā IT jomā var atrast arī citus darba devējus, ja līdzšinējie vairs neapmierina. Zigurds uzskata sevi par ieguvēju tajā ziņā, ka viņš saṇem salīdzinoši augstu Norvēǵijas algu, ko pamatā tērē Latvijā, un tas l̦auj veidot uzkrājumus.

\section{ĀRSTES PIEREDZE: LUİZE}

Luīze 2010. gadā bija ieguvusi pilnu augstāko medicīnisko izglītību Latvijā un izgājusi rezidentūru savā specialitātē. Viṇa strādāja par ārsti kādā no Latvijas pilsētām, bet pienēèma lēmumu aizbraukt no Latvijas un mēǵināt atrast darbu Somijā, jo bija iepazinusies ar vīrieti no Somijas un vēēejās uzsākt dzīvi ar viṇu Somijā. Tur viṇa atrada iespēju stažēties kā novērotāja Helsinku Universitātes slimnīcā, bet pastāvīgu darbu nevarēja atrast, tādēḷ atgriezās Latvijā.

"Vispirms es aizbraucu uz Somiju. Es aizbraucu tāpēc, ka biju satikusi vīrieti no Somijas. Tā bija ǵimenes apvienošana [..]. Pirmo gadu es meklēju darbu medicīnā. Pēc tam es meklēju jebkādu darbu - par apkopēju, pastā. Un es nekur nevarēju darbu atrast. Varbūt man vienkārši nepaveicās. Man jau arī valoda bija ḷoti labā līmenī. [..] Bet pēc diviem gadiem es atgriezos Latvijā, jo es nevarēju Somijā atrast darbu. Tas loti ietekmēja visu pārējo situāciju, tas man nebija pieņemami. Bet arī Latvijā es vairs nevarēju atpakaḷ iedzīvoties. Laikam tā mentalitāte loti mainās. Es nevarēju pieņemt to situāciju medicīnā, kāda ir Latvijā. Ne tik ḷoti finansiālā ziṇā, bet psihologiskā ziṇā. Tad es sañēmu darba piedāvājumu no Norvēéijas, un tad es aizbraucu prom.”

Atgriežoties Latvijā pēc Somijas pieredzes, Luīzei bija grūti pieṇemt Latvijas situāciju, jo viṇa sastapās ar negatīvu attieksmi no vecāko kolēğu puses un nevēlēšanos ar viṇu sadarboties:

"Pēc atgriešanās no Somijas es gribēju strādāt tādā mazā pilsētā Latvijā medicīnas jomā. Bet Latvijā ir tāda problēma, ka mazajās pilsētās vispār nav jauno ārstu. Ir tikai tādi pirmspensijas vecuma. No vienas puses, slimnīcas vadība l̦oti grib, lai tie jaunie ārsti atgriežas, bet, no otras puses, tie 
vecie ārsti nepieṇem. Viṇiem ir kaut kāda trauksme, viṇi ḷoti satraucas, ka viṇiem tiks kaut kas atṇemts. L̦oti negatīvi attiecas pret jaunajiem kolēgiem. Vini jūtas apdraudēti.”

Profesionālā ziṇā nejuzdamās labi Latvijā, Luīze bija priecīga par kursa biedrenes uzaicinājumu doties uz Norvēǵijas slimnīcu, kur tika meklēts speciālists viṇas jomā:

"Bija tā, ka mani Norvēgijā strādāt uzaicināja mana kursa biedrene. Jo Norvēgijā ir tā, ka viṇi svešus nepien,em. Ir l̦oti grūti kādu atlaist, tādēl viṇi pieñem caur paziṇām. Man ḷoti paveicās.”

Lai Luīze dabūtu pastāvīgu darbu, viṇai tika izvirzìts noteikums - trīs mēnešu laikā jāapgūst norvēǵu valoda, lai varētu pieņemt pacientus. Darba devējs viṇai nodrošināja intensīvos kursus norvēgeg valodā (8 stundas dienā), un Luīze šo uzdevumu izpildīja:

"Es atbraucu, norvēgiiski es praktiski nerunāju. Man nodaḷas vadītājs ir no Sīijas, viņš bija mācījies Maskavā, runāja krieviski. Mums bija tāda noruna. Ja es pēc trīs mēnešiem varu sākt strādāt poliklīnikā, tas nozīmē diezgan brīvi runāt norvēgiski, tad es palieku. Ja nē, tad es braucu prom. Man tikai nodrošināja 8 stundas norvēgu valodas kursus dienā un iespēju būt slimnīcā, cik ilgi es vēlos."

\begin{tabular}{|c|c|c|c|c|c|c|c|c|c|c|c|}
\hline & 1998 & 2000 & 2008 & 2010 & 2011 & \multirow{3}{*}{$\begin{array}{c}2012 \\
\text { Somija }\end{array}$} & \multirow{3}{*}{$\frac{2013}{\text { LV }}$} & 2014 & 2015 & 2018 & 2019 \\
\hline Mìtnes valsts & \multicolumn{5}{|c|}{ LV } & & & \multicolumn{4}{|c|}{ Norvēǵija (NO) } \\
\hline \multicolumn{10}{|l|}{\begin{tabular}{|l|} 
Augsti kvalificēts \\
vadošs darbs
\end{tabular}} & & \\
\hline $\begin{array}{l}\text { Augsti kvalificēts algots } \\
\text { darbs }\end{array}$ & & & & & Darbs LV & Stažěšanās & Darbs LV & \multicolumn{4}{|c|}{ Darbs NO } \\
\hline \multicolumn{12}{|l|}{ Mazkvalificēts darbs } \\
\hline Izglitīiba & \multicolumn{4}{|c|}{ Augstākā izglitīiba medicinā LV } & & & & & & & \\
\hline Valodas apmācības & & & & & & & & & & & \\
\hline $\begin{array}{l}\text { Bezdarbs / darba } \\
\text { meklēšana }\end{array}$ & & & & & & $\begin{array}{c}\text { Darba } \\
\text { meklēšana }\end{array}$ & & & & & \\
\hline G̦imenes faktori & & & $\begin{array}{c}\text { 1. bērna } \\
\text { piedzimšana }\end{array}$ & & & & & & & $\begin{array}{l}\text { 2. bērna } \\
\text { piedzimšana }\end{array}$ & \\
\hline $\begin{array}{l}\text { Profesionāla sadarbība } \\
\text { ar Latviju }\end{array}$ & & & & & & & & & & Darbojas LĀZ & \\
\hline
\end{tabular}

2.14. attēls. Dzīves un darba trajektorijas. 32. Sieviete, 40 gadi, ārste, Norvēǵija, emigrējusi 2012. gadā 
Tagad Luīze ir labi pelnoša ārste Norvēǵijā, viṇai pirms gada ir piedzimusi meita, bet tas netraucē pēc bērna kopšanas atvaḷinājuma turpināt strādāt labi atalgotajā vietā. Paralēli darbam Luīze ir aktīva LĀZA biedre un lasa lekcijas Latvijas studentiem par savu pieredzi Norvēǵijā:

"Es esmu arī LĀZA valdē, mums ir aktīva grupa, un mēs palīdzam Latvijas studentiem un ārstiem. Pēc divām nedēḷām man arī būs lekcija, satikšanās ar Latvijas studentiem, stāstǐšu, kā ir strādāt Norvēéijā. Jo ir l̦oti grūti sadarboties ar jau gataviem ārstiem, bet ar studentiem, tiem, kas rezidentūrā, ar viņiem vēl var darboties, var mainīt to domāšanu. Tādā veidā mēs domājam, ka arī Latvijā tā medicīna var mainīties.”

Luīzes stāsts atklāj, ka gadījumā, ja nepaveicas atrast ārsta darbu vienā vietā, tas nenozīmē, ka to nevar atrast citur. Darbu atrast viṇai palīdzēja kursa biedrenes ieteikums un mobilizācija norvēǵu valodas apguvē. Luīze labprāt sadarbojas ar Latvijas studentiem vai jaunajiem ārstiem un darbojas LĀZA, jo uzskata, ka Latvijas veselības aprūpes sistēmai vajadzētu būtiski mainīties.

\section{SECINĀJUMI PAR NORVĒG̣IJAS PIEREDZES STĀSTIEM}

Trīs izvēlētie Norvēǵijas pieredzes stāsti ir ḷoti atšḳirīgi, bet tos vieno kāda īpatnība: neviens no konkrētajiem emigrantiem nav Norvēǵijā ieguvis augstāko izglītîbu, tādēḷ tie nesniedz ieskatu Norvēgijas izglītības pieredzē. Šajos stāstos emigranti augstāko izglītību specialitātē ir ieguvuši Latvijā, bet stāsti atklāj, ka Norvēgija ir pietiekami atvērta valsts un tajā ir iespējams iekḷauties arī ar Latvijā iegūtu augstāko izglîtību. Vienā gadījumā izglītība iegūta finansēs, un tas ir ḷāvis specializēties Norvēǵijas un Latvijas sadarbības projektu konsultēšanā. Citā gadījumā IT speciālista un vadītāja izglītība un liela starptautiskā pieredze devusi iespēju iekḷauties Norvēǵijas darba tirgū. Vēl citā gadījumā Norvēgija ir atzinusi Latvijas medicīnas izglîtību par atbilstošu. Divos no aplūkotajiem pieredzes stāstiem l̦oti nozīmīgs aspekts ir Norvēǵijas valodas un kultūras pieņemšana, kas ir būtisks priekšnoteikums integrācijai darba tirgū un sabiedrībā. Atšḳirīgs ir stāsts par darba pieredzi starptautiskā uzṇēmumā, kas nodarbojas ar IT risinājumiem. Šajā vidē norvēǵu valodas zināšanām nav tik būtiskas nozīmes. Vienlaikus norvēǵu valodas zināšanu trūkums mazina piederības sajūtu Norvēgijai un veicina tāda dzīves modeḷa izvēli, kur iespējams apvienot darbu Norvēgiijā ar dzīvi Latvijā. 


\section{BŪVINŽENIERA PROFESIONĀLĀ KARJERA: KRISTAPS}

Kristapa kā būvinženiera profesionālā karjera aizsākās Latvijā. Pēc civilā inženiera bakalaura grāda iegūšanas Rīgas Tehniskajā universitātē (RTU) Kristaps sāka strādāt par būvinženiera asistentu starptautiskā uzṇēmumā Latvijā. Pēc maǵistra grāda iegūšanas RTU viņš turpināja izglītoties Dānijā, kur ieguva mağistra grādu Dānijas Tehniskajā universitātē ar specializāciju būves informācijas modelēšanas (angl. - Building Information Modeling) tehnoloǵijās. Ar Dānijas maǵistra grādu viņš vēlējās atrast darbu Dānijas darba tirgū, bet piedāvājums Zviedrijā bija pievilcīgāks, tādēḷ Kristaps izvēlējās strādāt Zviedrijā:

"Es Zviedrijā esmu no 2013. gada, sešus gadus. Kā es atradu darbu? Es meklēju darbu Dānijā. Zviedrijā es darbu nemeklēju, darbs mani pats atrada. Dānijā nebija tik labs piedāvājums, tādēḷ nolēmu strādāt Zviedrijā.”

Kristaps uzskata, ka profesionālā ziṇā starptautisks uzṇēmums Latvijā būtiski neatšķiras no starptautiska uzṇēmuma Zviedrijā, un, n̦emot vērā to, ka konkrētajam Zviedrijas uzṇēmumam interesēja sadarbība ar Baltijas valstīm, tas piedāvāja Kristapam darbu:

"Mani atrada, pateicoties tam, ka ārzemju firmas jau meklē darbiniekus no tām valstīm, ar kurām grib nākotnē sadarboties. Un tās ir Baltijas valstis, jo profesionāli nav tik lielas atšķirības. Tas bija viens no noteicošajiem faktoriem. Varbūt pirms 10 gadiem viṇi vēl nezināja, kā tas ir - strādāt ar Baltijas firmām, bet tagad tas ir viens un tas pats."

Saskaṇā ar Kristapa viedokli profesionāāā ziṇā nav lielas starpības - strādāt Latvijā vai Zviedrijā, bet atškirī̄bas ir vērojamas objekta sākotnējās izpētes posmā, un Zviedrijā ir arī augstāka reglamentācijas pakāpe:

"Es biju strādājis labās firmās Latvijā. Būtiskas atšḳirības profesionālā ziṇā nav. Galvenā starpība ir attieksmē un tajā, cik detalizēti tiek izpētìta informācija. Zviedrijā visa informācija tiek loti detalizēti izpētīta, līdz ar to pēc tam procesi notiek ātrāk. Laiks vairs lieki netiek tērēts. [..] Zviedrijā profesionāli viss ir l̦oti reglamentēts. Ir ḷoti skaidras amata prasības, pienākumi, struktūra ir ḷoti labi aprakstīta. Viss ir skaidrs. Man jau arī bija pieredze starptautiskā firmā, līdz ar to nekādu problēmu nebija. Ir kaut kādas savas nianses, bet kopumā - loti līdzīgi.” 
Augsti kvalificēts vadošs darbs Augsti kvalificēts algots darbs

Mazkvalificēts darbs

Izglītība

Valodas apmācības

Bezdarbs / darba meklēšana

Ģimenes faktori

Profesionāla sadarbība ar Latviju

2.15. attēls. Dzīves un darba trajektorijas. 45. Virietis, 35 gadi, būvinženieris, Zviedrija, emigrējis 2013. gadā

Savukārt studiju pieredze Latvijā un Dānijā gan ir atšḳirīga, jo Dānijā studiju process ir ievērojami interesantāks un centrēts uz konkrēto specializāciju, kamēr Latvijā tajā periodā, kad Kristaps studēja, nebija iespēju izvēlēties studiju kursus:

“Dān,u augstskolās ir daudz interesantāk mācīties. Vairāk grupas darbu, prezentāciju, vizītes uz būvlaukumu, sadarbība ar būvniecības firmām. Programma ir daudz interesantāka, mācību priekšmeti ir vairāk fokusēti uz praktisko. Palīdz saprast, ko students vēlas. Students var izvēlēties tieši to, ko vēlas. [..] Latvijā visi bija obligātie mācību priekšmeti, nekādas izvēles, un no tiem liela daḷa nebija pielietojami. Šobrīd pat neatceros, ko tajos mācīja."

Pēc četriem gadiem vienā amatā Zviedrijā Kristaps ir pakāpies profesionālajā karjerā un kḷuvis par vadītāju. Tuvākajos gados viṇš neplāno neko mainīt un pagaidām nedomā ar̄̄ atgriezties Latvijā. Viņš uzskata, ka pēdējo gadu laikā Latvijas uzṇēmumu un profesionālo būvnieku ziṇā situācija Zviedrijā ir sakārtojusies - Zviedrijā palikuši tikai uzṇēmīgākie un profesionālākie speciālisti un uzṇēmumi:

"Pēdējo gadu laikā daudzas firmas ir sapratušas, kas tas nav vienkārši šeit strādāt, tādēḷ ir palikuši tieši spēcīgākie spēlētāji. Tas pats ir arī par cilvēkiem. Palikuši ir tie, kas grib šeit būt, grib eksporta tirgu, ir aktīvi, meklē iespējas, kā attīstīties. Nekas nav tik viegli, ir jādomā ilgtermiņā, ḷoti daudz jāliek uz ilgtspēju.” 
Kopumā Kristapa pieredze atklāj, ka būvinženierim ar pieredzi starptautiskā uzṇēmumā Latvijā un Dānijas Tehniskās universitātes maǵistra grādu ir labas izredzes veidot savu karjeru Zviedrijā.

PĒC 20 GADIEM EMIGRĀCIJĀ - UZN̦ĒMĒJA: MELISA

Melisas cel̦š no Latvijas mazpilsētas uz Zviedriju aizveda 20. gadsimta 90. gados, kad viṇai no Latvijas Sarkanā Krusta piedāvāja braukt uz apmācībām Zviedrijā. Piedāvājums tika izteikts, jo viṇa sal̄̄dzinoši labi prata angḷu valodu, ko bija apguvusi pašmācībā. Savukārt, mācoties Zviedrijā, viṇa iepazinās ar zviedru puisi un tā 1996. gadā devās uz Zviedriju:

"Es labi zināju angḷu valodu, un man piedāvāja braukt uz Zviedriju mācīties no Latvijas Sarkanā Krusta. Viṇi meklēja cilvēkus, lai apmācītu, kuri varētu palīdzēt Sarkanā Krusta darbībai Latvijā. Manā mazpilsētā daudz tādu angliski runājošu cilvēku nebija, tāpēc es aizbraucu. Kādu laiku pamācījos, kā Sarkanajā Krustā dara visas lietas, un, kā jau visas latviešu meitenes, iepazinos ar puisi. Tad atbraucu atpakaḷ uz Latviju, strādāju Sarkanajā Krustā, vēlāk strādāju viesnīcā, taču tad uzradās doma pamēgināt braukt strādāt Zviedrijā. Puisis bija, iespēja bija, toreiz tik viegli tur tikt nevarēja, ja nebija nekādu sakaru. Tā es kādu laiku aizbraucu atpakal pie puiša."

Sākumā Melisa dzīvoja pie drauga, strādāja viṇa vecāku restorānā un mācījās zviedru valodu, jo vēlējās Zviedrijā iegūt augstāko izglītību. Nokārtojusi gan angḷu valodas, gan zviedru valodas eksāmenus, viṇa varēja iestāties kādā Zviedrijas augstskolā un iegūt izglîtību (Zviedrijā augstākā izglîtība ir bez maksas). Paralēli studijām Melisa turpināja brīvajā laikā strādāt restorānā:

“Mana drauga vecākiem piederēja restorāns, es tur varēju uzreiz strādāt par oficianti, nopelnīt mazliet naudu. Uzreiz stājos iekšā valodu kursos. Drauga tētis teica: "Zviedriski runāt nav tik grūti, ej, n,em ēdienkarti un ej pie viesiem pieṇemt pasūtījumus.” Tā arī tā zviedru valoda ātri aizgāja. Vienmēr ir bijis mērk,is studēt, bet Latvijā tie bija briesmīgākie gadi, jo naudas nevienam vecākam nebija, un studēt Latvijā iespējas nebija, tāpēc, atbraucot uz Zviedriju, izmantoju šo iespēju studēt. Ātri izmācījos zviedru valodu, kas bija nepieciešama studijām, tad man bija jāpārliek angḷ valodas eksāmens, jo Latvijas angḷu valodas atzīmes šeit netika pien,emtas kā līdzvērtīgas, noliku zviedru valodas eksāmenu un iestājos universitātē.”

Darbu Zviedrijā savā specialitātē Melisa ieguva, pateicoties tam, ka ir no Latvijas un ka ir ieguvusi Zviedrijas ekonomisko izglītību. Tie ir arī viṇas 


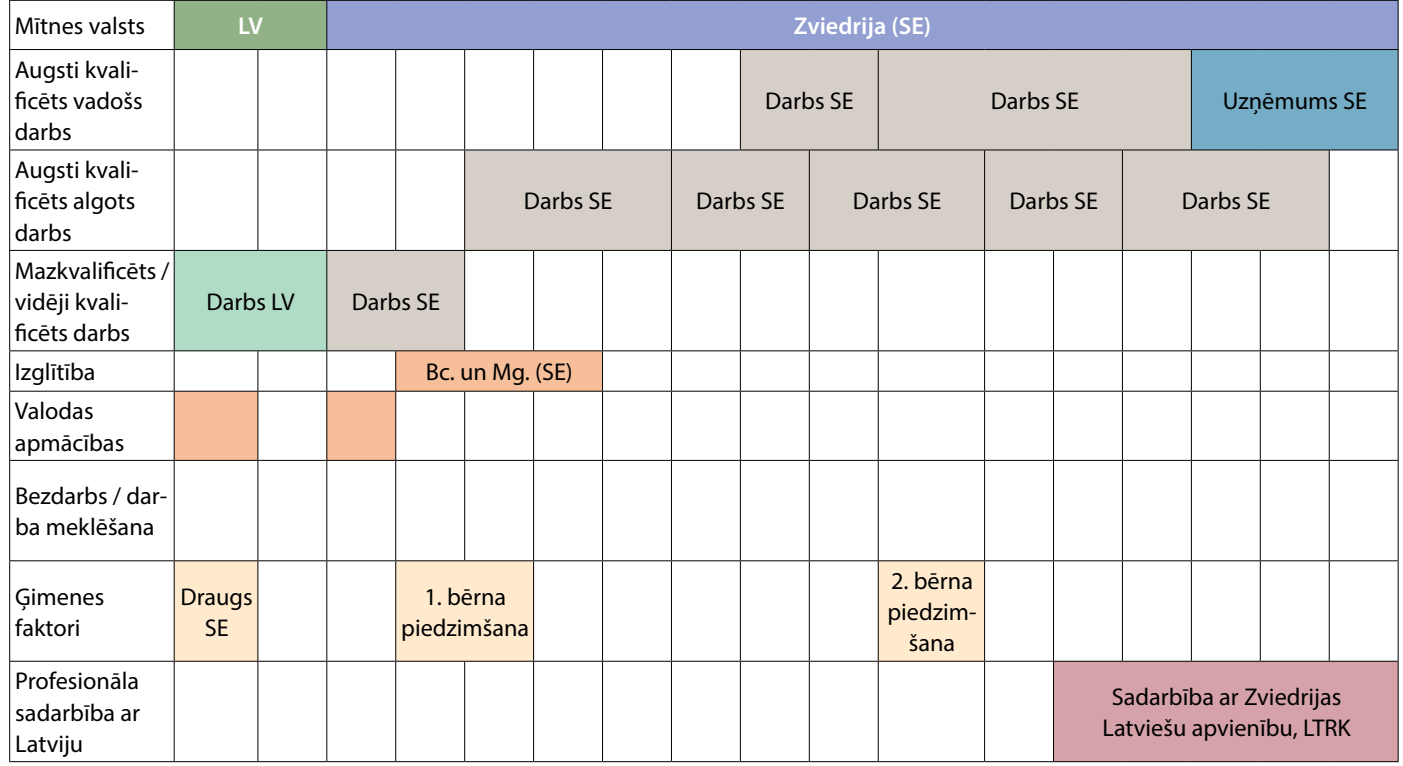

2.16. attēls. Dzīves un darba trajektorijas. 46. Sieviete, 43 gadi, uzṇēmēja, Zviedrija, emigrējusi 1996. gadā

galvenie atslēgvārdi, atbildot uz jautājumu, kas bija būtiskākie aspekti, kuri palīdzēja veidot karjeru:

“Saikne ar Latviju un zviedru izglītība. Toreiz bija "Parex” banka, kas meklēja cilvēkus, kas būtu “ar vienu kāju iekšā abās valstīs”, proti, mācētu strādāt gan ar zviedriem, gan ar latviešiem. Iekārtojos l̦oti labā darbā, jo nebija daudz tādu cilvēku ar Zviedrijas izglītību. Tas man palīdzēja sākt strādāt ekonomikas jomā."

20 gadus pēc ierašanās Zviedrijā Melisa tur ir izveidojusi savu konsultāciju uzṇēmumu, kas specializējas fintech jaunuzṇēmumu un Zviedrijas-Baltijas uzṇēmumu konsultēšanā finanšu jautājumos.

“Nu jau ilgāku laiku biju domājusi, ka jāsāk darīt kaut kas sev, un, ņemot vērā savu pieredzi un redzot internetā sociālajos tīklos dažādus jautājumus, kādi cilvēkiem rodas... Zviedrijā ir liela latviešu kopiena un daudz jaunu cilvēku brauc uz Zviedriju no Latvijas, un, redzot, ka daudziem uzṇēmējiem nav 
skaidrs, kā tur notiek uzṇēmējdarbība, vēlējos kaut kā palīdzēt. No sākuma palīdzēju brīvprātīgi, taču, tā kā tas ir diezgan apjomīgs darbs, izdomāju, ka tas varētu būt labs bizness.”

Melisas stāsts atklāj latviešu uzṇēmējas pieredzi Zviedrijā - sākotnēji darba iespējas veidojās uz personīgo attiecību pamatiem (draugs Zviedrijā), bet, ieguvusi izglītību un darba pieredzi Zviedrijā, 20 gadu laikā Melisa varēja izveidot savu uzṇēmumu fintech jaunuzṇēmumu konsultāciju jomā. Nozīmīgākais atbalsts viṇas vērtējumā ir bijusi iespēja bez maksas iegūt augstāko izglîtību Zviedrijā un studējošā kredīts, ko sniegusi Zviedrijas valdība. Melisas profesionālā pieredze visu laiku nav bijusi atrauta no Latvijas, jo lielākoties viṇas profesionālā darbība ir saistijjusies ar Zviedrijas un Baltijas finanšu attiecībām.

\section{ZINĀTNISKAIS DARBS TUR UN ŠEIT: RITVARS}

Ritvars uz Zviedriju devās, vēl studēdams bakalaura studiju programmā, jo bija iesaistīts zinātniskā institūta projektā, kuram bija sadarbība ar Zviedriju. Laikā, kad viņš tur atradās, veicot projekta darbus, viņam piedāvāja studēt fiziku starptautiskā maǵistrantūras programmā Zviedrijā, un viņš iesniedza dokumentus.

"Es tur biju aizbraucis drusku pastrādāt ar kādu projektinu. Un tur tā sakrita, ka tajā brīdī tur bija izsludināts konkurss uz starptautisko magistrantūras programmu. Viniem tur vajadzēja arī cilvēkus no Baltijas valstīm, un man jautāja, vai es negribu pieteikties. Tã es tur pieteicos.”

Pēc maǵistrantūras programmas viṇam piedāvāja turpināt studijas doktorantūrā, un viņš šo piedāvājumu pien̦ēma. Kopumā viņš Zviedrijā nodzīvoja septiṇus gadus, tomēr ciešāka piederība Zviedrijas sabiedrībai neizveidojās, visu savu uzturēšanās laiku Ritvars nodzīvoja universitātes kopmītnēs un pēc doktora grāda iegūšanas atgriezās Latvijā. Lai gan Latvijā šajā periodā zinātnes finansējums viṇa specializācijā nebija augsts, viṇš tomēr izvēlējās atgriezties:

“Ārzemēs es negribu, septinuus gadus tur sabiju, vairāk negribu. Kaut kur ir jāizdomā, kur tu paliksi, Zviedrija nebija tā vieta, kur man gribējās dzīvot. Man šeit arī patīk tā daudzveidība. Ir gan studenti, gan pētniecība. Arī tas darba režīms ir brīvs. Tu nāc un ej, kad gribi. Pats izdomā, ko darīsi.”

Finansiālu apsvērumu dēḷ Ritvars četrus gadus strādāja privātajā sektorā, kur vadīja projektus elektronikas jomā, sakaru telekomunikācijā, kas sniedza daudz jaunu zināšanu: 


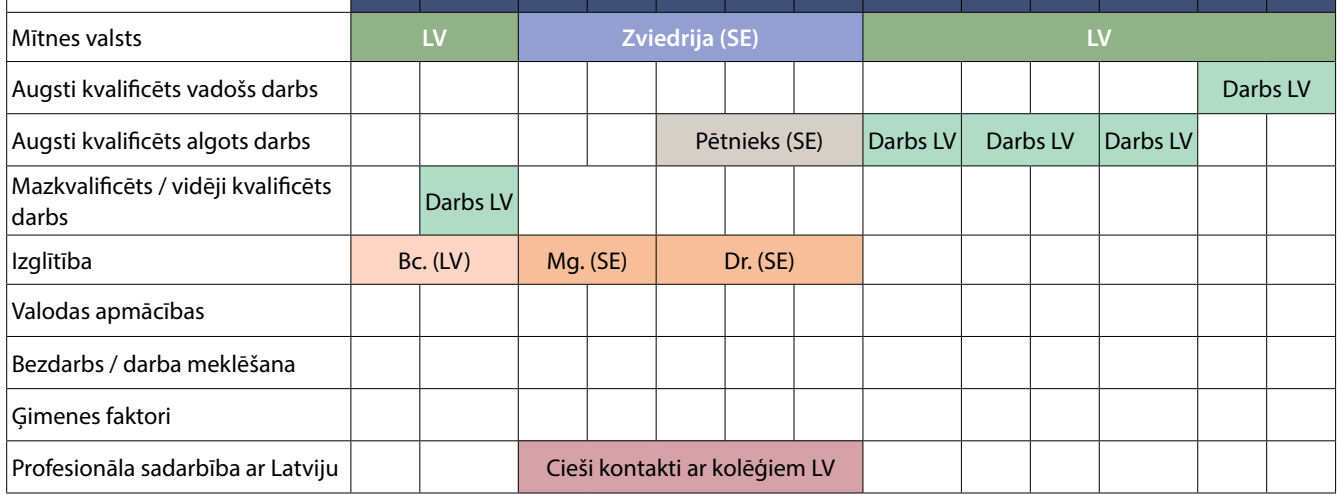

2.17. attēls. Dzīves un darba trajektorijas. 41 . Vỉrietis, 47 gadi, fiziḳis, Zviedrija, emigrējis 1996. gadā, atgriezies 2003. gadā

"Pēc 2000. gadiem tas finansējums zinātnē bija neatbilstošs. Tad es pastrādāju kādu laiku privātajā sektorā. Tur es biju projektu vadītājs elektronikas jomā, sakaru telekomunikācijā. Tā es tur sabiju četrus gadus. Četros gados es loti daudz ko iemācījos. Bija interesanti. Tāds kā vēl viens bakalaurs, bet ne vairāk. Nostrādāju no 2005. gada līdz 2009. gadam.”

Tomēr, kad parādījās iespēja atgriezties zinātniskajā darbā universitātē, viņš bija priecīgs, ka ir iespēja strādāt par pasniedzēju un veikt zinātniskus pētījumus, ko turpina joprojām.

Ritvara stāsts atklāj jaunā zinātnieka pieredzi Zviedrijā, ko viṇš pats vērtē ar vārdiem: "Tas ir labs starts darbam zinātnē. Tas bija ḷoti vērtīgs posms." Tomēr Zviedrijā viņš nevēlējās dzīvot, tādēḷ atgriezās Latvijā, lai arī finansējums zinātnē un atalgojums tajā brīdī nebija motivējošs. Atgriešanos Latvijā atviegloja tas, ka visu laiku, kamēr Ritvars bija Zviedrijā, viṇš uzturēja kontaktus arī ar kolēgiem Latvijā.

\section{SECINĀJUMI PAR ZVIEDRIJAS PIEREDZES STĀSTIEM}

Zviedrijas pieredzes tuvplānam izvēlēti būvinženiera, uzṇēmējas un fiziķa dzīvesstāsti. Šajos stāstos par aizbraukšanu no Latvijas mazāk ir uzsvērta vilšanās vai iespēju trūkums, bet akcentētas jaunas iespējas, ko sniedz dzīve Zviedrijā. Uzṇēmējas un fiziḳa Zviedrijas pieredzē īpaši ir izcelta Zviedrijā iegūtā izglītība, kas tiek raksturota kā būtisks aspekts turpmākajai karjerai, kā labs starts. Abi informanti l̦oti pozitīvi vērtē Zviedrijas izglītības sistēmas 
sakārtotību un plašo piedāvājumu, kā arī pieejamību, jo Zviedrijā augstākā izglītība bija bez maksas un bija pieejami kredīti ar l̦oti zemām procentu likmēm, lai segtu dzīvošanas izdevumus. Būvinženieris izglìtību augstākajā līmen̄̄ ieguva Dānijā, kuras izglītības sistēmas augstais vērtējums ir līdzīgs Zviedrijas izglītības sistēmas vērtējumiem. Kopumā šie stāsti atklāj, ka tiem, kas vēlas mācīties un strādāt, Zviedrijā ir visas iespējas, un tā ir atvērta sabiedrība. Vienlaikus ne visi emigranti Zviedrijā vēlas palikt.

\section{SECINĀJUMI}

Šajā nodaḷā veiktā padziḷināto interviju analīze, kurā izmantota naratīvo interviju dokumentārās interpretācijas metode (Nohl, 2010), ḷauj izsekot migrācijas radītajai statusa maiṇai ikdienas pieredzēs. Tā atklāj dažādu pārejas situāciju faktoloğisko secību. Darba trajektoriju izpēte parāda, ka pirmie darbi emigrācijā lielākoties ir stažiera vai mācekḷa pozīcijās, kur īsāks vai ilgāks laika posms paredzēts konkrētā konteksta un prakšu apguvei. Tas attiecas uz tādām pozīcijām kā jaunākais speciālists, praktikants, stažieris, māceklis, kā arī uz rezidentūras sākumposmu ārstniecības iestādēs. Pēc stažiera vai mācekḷa posma, kuru raksturo intensīva mācīšanās, apgūstot gan valodu, gan konkrētās prakses, un salīdzinoši zems atalgojums, šajos piemēros seko profesionālā nostabilizēěanās un karjeras attīstība. Jāuzsver, ka šajā nodaḷā aplūkotās pieredzes raksturo migrācijas veiksmes stāstus profesionālajā dzīvē, jo dzīvesstāstu atlase paredzēja, ka emigranti ir veiksmīgi savā profesionālajā karjerā un strādā sfērā, kas atbilst viṇu izglītībai.

Mikrolīmenī un mezolīmenī analīze atklāj dažādu sabiedrības apakšsistēmu pārklāšanos un ietekmi migrācijas lēmumu pieņemšanā. Gan lēmumi par emigrāciju, gan lēmumi par atgriešanos Latvijā vairākos dzīvesstāstos primāri ir ǵimenes vai attiecību faktoru definēti, bet tie saistās ar citām sabiedrības apakšsistēmām un cits citu papildina. Piemēram, pamatojumā emigrēt sasaistās partnera iespēja emigrēt un neapmierinātība ar izglītības iespējām Latvijā. Citā gadījumā pamatojums atgriezties Latvijā saistās ar partnera vēlmi veidot ǵimeni Latvijā, neapmierinātību ar pārslodzi darbā un pozitīvi vērtēto jauno gimeņu atbalstu Latvijā (maternitātes un vecāku pabalsts). Šajā gadījumā Latvijā îstenotā gimeṇu atbalsta politika atklāj jau makrolīmeṇa faktorus migrācijas lēmuma pieñemšanā.

Mezolīmenī analīze atklāj dažādus gadījumus un veidus, kā institucionalizēti vai neformāli sociālie tīkli bijuši būtisks faktors gan migrācijas lēmumu 
pien̦emšanā, gan izglītības iespēju, gan darba atrašanā. Piemēram, daudzos stāstos ārzemju latvieši ir sekmējuši migrācijas lēmuma pien,emšanu. Īpaši spilgti tas parādās ASV pieredzes stāstos, jo ASV Latvijas pilsoṇiem ir mazāk pieejams migrācijas režīms, un atbalsts migrācijas procesā ir vairāk nepieciešams. ASV latvieši ir gan uzaicinājuši studēt doktorantūrā, gan pal̄̄dzējuši atrast rezidentūras iespējas, gan palīdzējuši sagatavoties migrācijai. Eiropā lielāka nozīme ir profesionāli izveidotajiem kontaktiem (mezolīmenis) un izglītības sistēmām, kuras raksturo atvērtība jaunajiem zinātniekiem (makrolīmenis) ar dažādām pēcdoktorantūras un stipendiju iespējām. Vairāki informanti uzsvēra, cik svarīgi ir sevi labi parādīt, lai tiktu piedāvātas jaunas iespējas vai sniegtas pozitīvas rekomendācijas par darbu. Sociālie kontakti ir svarīgi, ne tikai lai uzzinātu par darba iespējām, bet arī lai sekmīgāk integrētos jaunajā darba vidē, tai skaitā darba kolektīvā.

Makrolīmenis šajā analīzē aplūkots kā plašākais konteksts konkrētajā valstī un ietver gan normatīvo regulējumu attiecībā uz migrantu iekḷaušanu, īpaši attiecībā uz valodas apguves, izglìtības un nodarbinātības jomu, gan arī regulējumu citās jomās (mājokḷa politika, ǵimenes politika utt.). Izglītības kontekstā nozīmīga ir jau iepriekš minētā dažādu izglītības sistēmu atvērtība imigrantiem, tai skaitā zemu procentu likmju kredītu pieejamība ārvalstu studentiem. Gan izglītības, gan ǵimeņu politikas atklājas kā valstu konkurences noteikti indikatori. Šajā konkurencē izglītības ziṇā Latvija diemžēl konkurencē ar aplūkotajām valstīm bieži vien zaudē, bet, piemēram, ǵimenes atbalsta politikas aspektā salīdzinājumā ar Lielbritāniju un ASV - iegūst. 
Neskatoties uz it kā acīmredzamajām priekšrocībām, kas raksturo augsti kvalificētus migrantus, it īpaši tos, kas emigrējuši uz Eiropas valstīm, jo pārcelšanās uz tām ir salīdzinoši ḷoti vienkārša, - arī augsti kvalificēti emigranti sastopas ar grūtībām adaptēties jaunajās mītnes valstīs. To atklāj pētījumi, kas veikti, piemēram, par augsti kvalificētu ungāru vai rumāṇu adaptāciju jaunajās mītnes valstīs (Csedö, 2008; Bailey \& Mulder, 2017). Šajā nodaḷā ir analizētas augsti kvalificētu Latvijas speciālistu adaptācijas stratēǵijas jaunajās mītnes valstīs, īpašu uzmanību pievēršot pētnieciskajam jautājumam par to, vai un kā viṇi ārvalstīs izmanto Latvijā iegūtās zināšanas un prasmes (kultūras kapitāls). Adaptācijas procesu analīzē aplūkoti dažādi šķērṣ̌li, ar ko augsti kvalificētie Latvijas emigranti sastopas, kā arī tas, kā dažādos gadījumos konkrēti šḳēršḷi tiek vai netiek pārvarēti un kā tiek izmantotas Latvijā un citās valstīs iegūtās zināšanas, prasmes un sociālie kontakti.

Šajā nodaḷā galvenā uzmanība pievērsta augsti kvalificētu emigrantu adaptācijai jaunā darba vidē. Jauna darbavieta jebkuram darba n̦ēmējam prasa pielāgoties videi, kolēgiiem, darba pienākumiem utt. Tomēr, ja salīdzina migrantu 
un pamata iedzīvotāju pieredzes, adaptējoties jaunā darbavietā, jāatzīst, ka migranti bieži vien ir mazāk informēti par konkrētā darba tirgus sektora īpatnībām uzṇemošajā valstî. Daudzas prakses, kas vietējiem darba n̦ēmējiem ir pašsaprotamas, ienācējam var būt kaut kas jauns.

Pētījumos, kas veikti par citu valstu emigrantiem, izšķirtas vairākas kategorijas, kurās vērojamas atškirīgas adaptācijas pieredzes. Vairākos pētījumos uzsvērts, ka atšķiras pieredzes tiem augsti kvalificētiem emigrantiem, kas uz citu valsti ir devušies darba devēja uzdevumā (piemēram, sniegt pakalpojumus vai strādāt uzṇēmuma filiālē), no tām pieredzēm, ar ko sastopas emigranti, kas paši meklē darbu (Csedö, 2008). Tiem, kas paši meklē darbu ārvalstīs, ir jāpierāda, ka viṇu kvalifikācija atbilst uzṇemošās valsts darba tirgus prasībām. Tam ir nepieciešamas gan valodas zināšanas, gan noteiktas prasmes (Csedö, 2008; Koikkalainen, 2013). Šajos gadījumos no augsti kvalificētiem speciālistiem tiek sagaidīta ne tikai atbilstoša izglìtība, darba pieredze, valodas zināšanas, vispārējās un speciālās profesionālās prasmes, bet arī prasme izmantot "pareizos" darbā pieteikšanās formātus, prasme izmantot "pareizos" darbā pieteikšanās kanālus, prasme "pareizi” izturēties un lietot "pareizo” valodu darba interviju laikā, zināšanas par atsauksmēm, ko sagaida vai prasa darba devējs (Csedö, 2008).

Citos pētījumos nošķirti tie augsti kvalificētie migranti, kas augstāko izglītību ieguvuši uzṇemošajā valstī, no migrantiem, kas izglītību ieguvuši savā izcelsmes valstī. Pētījumi atklāj, ka izglītības iegūšana konkrētajā valstī var sekmēt migranta integrāciju darba tirgū, jo paaugstina vietējo sociālo un kultūras kapitālu (Nohl et al., 2006; Friedberg, 2000). Konkrētajā valstī studējošie labāk izprot vietējā darba tirgus îpatnības, un to var uzskatīt par vienu no stratēǵijām, kā iekḷauties darba tirgū: vispirms iegūt augstāko izglītību mītnes valstī, vienlaicīgi arī apgūstot uzṇemošās valsts valodu.

Šajā analīzē iekḷautās padziḷinātās intervijas aptver gan tādus gadījumus, kad emigranti ir tikuši nosūtīti uz ārvalstīm (kopumā septiṇi gadījumi), gan arī tādus gadījumus, kad emigranti paši meklējuši darbu (43 gadījumi). Izglītības iegūšanas ziṇā interviju dalībniekus var iedalīt trīs grupās. Pirmā grupa ir tie, kas augstāko izglîtību ieguvuši tikai Latvijā (14 gadījumi), otrā - tie, kas izglītību ieguvuši gan Latvijā, gan ārvalstīs (27 gadījumi). Visos šajos gadījumos ārvalstīs izglītîba iegūta augstākā līmenī. Pie šìs grupas pieskaitīti arī ārsti, kas augstāko izglītību ieguvuši Latvijā, bet rezidentūru izgājuši ārvalstīs. Trešā grupa ir tie emigranti, kas augstāko izglītību ieguvuši tikai ārvalstīs (9 gadījumi). Adaptācijas pieredze analizēta šādās emigrācijas valstīs: Lielbritānija, Vācija, Norvēǵija, Zviedrija un ASV. 


\subsection{ADAPTĀCIJAS STRATĒG̣IJAS AUGSTI KVALIFICĒTU LATVIEŠU EMIGRANTU PIEREDZĒ}

Pētījumā veikto interviju analīzes rezultātā var identificēt trīs dažādus posmus un atbilstošas stratēǵijas adaptācijai darba tirgum ārvalstīs. Pirmkārt, var nodalīt sagatavošanās posmu migrācijai jeb pirmsmigrācijas adaptācijas stratēgijas. Pirmsmigrācijas posmu var raksturot kā periodu, kad indivīds gatavojas aizbraukšanai un savā darbībā un aktivitātēs jau lielā mērā orientējas uz uzṇemošo valsti, iegūst par to informāciju, plāno savu migrāciju.

Otrkārt, var izšḳirt tās adaptācijas stratēgiijas, kuras raksturīgas pārejas posmā - uzreiz pēc migrācijas un sākotnējās iedzīvošanās laikā. Šajā posmā emigrants atrod savu pirmo darbavietu, vai gadījumos, kad sākotnējais posms saistīts ar izglītības iegūšanu, vispirms uzsāk mācības augstākās izglītības iestādē un tikai tad meklē darbavietu. Šajā posmā tiek atrasts pirmais mājoklis un notiek intensīva valodas apguve.

Treškārt, var nošḳirt adaptācijas stratēgiijas, kas raksturīgas vēlākam posmam, kad pirmā adaptācija un zināma nostabilizēšanās uzṇemošajā valstī ir jau notikusi. Šis posms ir nosaukts par iedzīvošanās un stabilitātes posmu, kad Latvijas emigrantiem parasti parādās vairāk iespēju sadarboties ar Latviju un izmantot arī Latvijā iegūto kultūras kapitālu. Par nosacītu iedzīvošanās atskaites punktu var uzskatît brīdi, kad ir sasniegta zināma stabilitāte gan attiecībā uz nodarbinātību mītnes zemē, gan arī mājokli un sociālajiem kontaktiem. Magistra studijas šī pētījuma kontekstā drīzāk ir uzskatāmas par pārejas situāciju un atbilst otrajam posmam, bet doktora līmenis pētniecībā vai rezidentūras gadi noteiktās situācijās var atbilst arī trešajam - nostabilizēšanās - posmam.

\section{PIRMSMIGRĀCIJAS ADAPTĀCIJAS STRATĒG̣IJAS}

Pirmsmigrācijas adaptācijas stratēgijas visbiežāk izpaužas kā vairāk vai mazāk intensīva mītnes valsts valodas apguve dažādos kursos vai pašmācības ceḷā, kā arī informācijas un sociālo kontaktu apzināšana, gatavojoties aizbraukšanai vai meklējot darbu attālināti. Viens no ilgākajiem sagatavošanās posmiem, kas identificēts šajā pētījumā, ir trīs gadi. Šajā gadījumā ārsts rezidentūras laikā Latvijā mērḳtiecīgi gatavojās rezidentūrai ASV, izveidojot kontaktus ar ārzemju latviešiem, kuri palīdzēja sagatavoties nepieciešamajiem eksāmeniem, atrast rezidentūras vietu un nokārtot stipendiju:

"Sāku mācīties Amerikas medicīnas eksāmeniem, divu gadu laikā nokārtoju.

Tur bija divi soḷi, katram gadu veltīju, un trešais gads bija atrast rezidentūru 
Amerikā. Tāpēc būt̄̄bā, kad pabeidzu rezidentūru Latvijā, uzsāku rezidentūru N,ujorkā.” (20. Vīrietis, 48 gadi, ārsts, ASV, emigrējis 1997. gadā)

Citos gadījumos gatavošanās aizbraukšanai var būt l̦oti īsa, piemēram, IT speciālists pieteicās iespējamajā darbavietā un jau divas nedēḷas pēc Skype darba intervijas devās uz Londonu un sāka dzīvot tur:

"Sazinājāmies caur "Skype” uz interviju, tad pēc nedēlas izteica piedāvājuтu, kuru es pien̦ēmu. Uzrakstīju atlūgumu un pēc divām nedēlāam strauji sestdienā piezemējos Londonā, svētdienā atradu dzīvesvietu un pirmdienā sāku strādāt." (9. Vîrietis, 35 gadi, IT, Lielbritānija, emigrējis 2011. gadā)

Neatkarīgi no sagatavošanās posma ilguma tipiskākās augsti kvalificēto Latvijas emigrantu stratēgiijas šajā posmā ir saistītas ar valodas apguvi, informācijas apzināšanu par mītnes zemi un sociālo kontaktu veidošanu.

\section{PĀREJA UN SĀKOTNĒJĀ IEDZIVIVŠANĀS MITTNES ZEMĒ}

Neskatoties uz valodas zināšanām un gatavošanos pirms aizbraukšanas, padziḷināto interviju dalībnieki atzīst, ka sākotnējais periods viņiem saistījies ar pastiprinātu valodas mācǐšanos. Vienai no tipoloğiskajām augsti kvalificēto emigrantu grupām, kas identificēta šajā pētījumā, pagāja apmēram gads, dzīvojot mītnes zemē, līdz radās sajūta, ka sazināšanās mītnes zemes valodā vairs nesagādā grūtības:

"Es sapratu visu. Bet man bija grūtības izteikties. Trūka vārdu. Pagāja kāds gads, kad es varēju brīvi sarunāties.” (29. Vìrietis, 32 gadi, ārsts, Vācija, emigrējis 2012. gadā)

Emigranti Zviedrijā un Norvēǵijā norāda, ka viṇi ir izmantojuši Zviedrijas un Norvēgijias piedāvātās iespējas apgūt valodu bezmaksas kursos. Vairākos gadījumos iespēju mācīties valodu kursos informantiem ir palīdzējuši nokārtot viṇu darba devēji:

"Man jāpateicas vecā kluba īpašniekam, ka es tiku viengadīgā programmā "Norvēgu valodas kursi un vēsture ārvalstu studentiem". L,oti efektīva programma, kas gada laikā man iemācīja valodas pamatus. Tas bija liels atbalsts turpmākajam. Iedzīvošanās gan profesionāli, gan sadzīviski. [..] Gada laikā jau varēju brīvi sarunāties norvēgiski. Tas bija sākums." (31. Vīrietis, 35 gadi, finansists-grāmatvedis, Norvēgija, emigrējis 2011. gadā, atgriezies 2018. gadā) 
Paralēli valodas apguvei sākuma posmā Latvijas emigranti strādāja ḷoti daudz papildstundu, lai iegūtu darbā nepieciešamās zināšanas un prasmes. Īpaši informanti ASV, Lielbritānijā un Vācijā uzsvēra lielo mācīšanās slodzi pirmā gada laikā. Nepieciešamība papildus mācīties ir saistîta ar nedrošību par sevi un vēlmi pasniegt sevi labākā gaismā, pierādot, ka viṇi ir labi konkrētās jomas speciālisti. Šajos gadījumos darba diena nereti ilgst 12 stundas, dažkārt pašmācībai un profesionālajai pilnveidei tiek veltītas arī sestdienas un svētdienas. Šāda intensīva sevis pilnveidošana un vēlme pielāgoties jaunajai videi vērojama gan IT jomā, gan veselības aprūpē, gan arī starp tiem speciālistiem, kas strādā finanšu un ekonomikas jomā.

"Sākums bija diezgan grūts, jo banku biznesā tā ir, ka praktikants strādā no deviņiem līdz vismaz pusnaktij, arī nedēḷas nogalēs. Darbs bez apstājas. Tu esi visu laiku neizgulējies, tevi testē, vai tu vari izdarīt to darbu. Adaptācija bija tāda, mēs sākām četri praktikanti, un divus paṇēma.” (1. Vĩrietis, 28 gadi, specializācija jaunajās tehnoloǵijās, jaunuzṇēmuma vadīšanā, Lielbritānija, emigrējis 2011. gadā, atgriezies 2017. gadā)

Milzīga pārslodze un konstants stresa stāvoklis raksturo pāreju un sākotnējo iedzīvošanos mītnes zemē, un ne visi augsti kvalificētie emigranti šo posmu spēj izturēt. Tie, kas paliek mītnes zemē un strādā savā profesijā, ir salīdzinoši psiholoǵiski noturīgākie, jo ir spējuši sevi pārvarēt un izturēt sākumposma grūtības un lielo spriedzi:

“Sākums bija l̦oti grūts. Es nācu uz darbu 5 no rīta un strādāju līdz 9 vakarā. Tas informācijas apjoms bija milzīgs. Katru dienu man bija jāapseko kādi 30 pacienti un jāspēj par viṇiem noziņot virsārstam. Pēc pirmā pusgada man jau gribējās visu pamest un atgriezties Latvijā. [..] Tāda milzīga pārslodze un nepārtraukts stress. No stresa un atbildības es pat nevarēju gulēt. Bija ḷoti smagi. Tāds pirmsdepresijas stāvoklis. Es arī biju ḷoti prasīgs pret sevi." (29. Vìrietis, 32 gadi, ārsts, Vācija, emigrējis 2012. gadā)

Kā liecina Latviešu ārstu un zobārstu apvienības mājaslapā (LĀZA, 2016) pieejamā informācija, ārzemēs dzīvojošie psihiatrijas un psihoterapijas speciālisti 2016. gadā izveidoja medicīnas darbinieku atbalsta grupu "KONS”. Tās mērķis ir sniegt atbalstu ārzemēs dzīvojošiem un medicīnā strādājošiem kolēǵiem, kuri nonākuši garīgās un emocionālās grūtībās. Šī atbalsta grupa tika izveidota jauna un talantīga kolēga piemiṇai: 
"Bet kāpēc mès to darījām? Pēc viena jaunā ārsta, kas bija arī Jauno ārstu asociācijas biedrs, pašnāvības. Nav noslēpums, ka ārsti ir viena no riska grupām, un Latvijā diezgan daudz jauno ārstu ir izdarījuši pašnāvības. [..] Mēs apzinājām toreiz piecus psihiatrus/psihoterapeitus dažādās valstīs (Kanādā, Norvēgijā, Zviedrijā, Lielbritānijā) un izveidojām dežūru plānu, kad divus mēnešus dežurants pārbauda e-pastu reizi dienā. [..] Bet kāpēc mums likās svarīgi sniegt palīdzību ārstiem? Tāpēc, ka mēs paši esam ārsti un zinām, ko tas nozīmēe. Kas ir vajadzīgs un ar kādām grūtībām ārsti sastopas, īpaši ārstu karjerā. Lielākā daḷa no mums, mēs esam arī imigranti. Mēs zinām arī to visu. Mēs varam palīdzēt arī psihiatrijas/psihoterapijas veidā, bet galvenokārt ar to, ka mēs varētu palīdzēt cilvēkam atrast veidu, kā risināt problēmas un saņemt palīdzību tajā vietā, kur viṇš dzīvo.” (8. Vìrietis, 48 gadi, ārsts, Lielbritānija, emigrējis 2005. gadā)

Lai labāk iejustos jaunajā darba kolektīvā, viena no adaptācijas stratēǵijām ir izveidot draudzīgas attiecības ar darba kolēǵiem un atrast kādu mentoru, kas dod padomus, kā labāk risināt noteiktas problēmsituācijas:

"Bija svarīgi atrast kādu "mentoru”, kurš tev palīdzēs atrast un saprast tās svarīgās lietas. Bija tāds viens, kurš bija gadu pirms manis sācis, mēs sadraudzējāmies, un tad viņš pastāstīja, kā reagè̃t uz partneriem, kā reagēêt uz dažādiem cilvēkiem, kā pareizi uzvesties. Bet tajā pašā laikā ar citiem cilvēkiem man bija smagas un konfliktu pilnas attiecības, viṇi vienkārši gribēja ieriebt. Uzskatīja, ka praktikantus var tirināt, kā grib, apmēram "tas ir praktikantu darbs - darīt visas sliktās lietas”. Nu, mēnesi pa mēnesim tas uzlabojās.” (1. Vìrietis, 28 gadi, specializācija jaunajās tehnologiijās, jaunuzṇ̄emuma vadīšanā, Lielbritānija, emigrējis 2011. gadā, atgriezies 2017. gadā)

Padziḷinātās intervijas atklāj dažādas pieredzes saistībā ar pirmo darbavietu. Ir tādi informanti, kuriem pirmā darbavieta mītnes zemē ir vienīgā un karjeras izaugsme notiek vienā organizācijā. Tādi piemēri ir veselības aprūpes sfērā, kur ārsts par savu rezidentūras vietu mērḳtiecīgi ir izvēlējies augsta līmeņa universitātes slimnīcu, kurā ir interesantas pētniecības un profesionālās attīstības iespējas. Citos gadījumos pirmā darbavieta uztverta tikai kā sākotnējais tramplīns un paralēli darbam tiek meklēti jauni kontakti, jaunas iespējas un interesantāki darba piedāvājumi (vairāk par karjeras trajektorijām skatît 2. nodaḷā "Izglītības un darba trajektorijas. Dzīves gaitas perspektīva”).

Veiksmīgos augsti kvalificētos Latvijas emigrantus, kas emigrācijā strādā prestižos uzṇēmumos, raksturo tas, ka viṇi ir ḷoti prasīgi pret sevi. Viṇi 
apzinās: lai attīstītu savu karjeru, ne tikai ir jābūt augstas klases profesionālim, bet arī jāprot sevi ḷoti labi un pārliecinoši pasniegt. Darbs, lai uzlabotu mākslu sevi pasniegt, un kontaktu veidošana ir veids, kā iegūt profesionālu atzinību:

“Būt labam profesionālim nozīmē divas plaknes: spēt īstenot rezultātus, $k u-$ rus prasa, un otrs ir "perception" [uztvere], tas, ka cilvēki uztver tevi kā profesionāli. Ja pat tu esi labākais savā jomā, bet cilvēki tevi nezina, tu būsi loti ierobežots savā karjerā." (9. Vĩrietis, 35 gadi, IT, Lielbritānija, emigrējis 2011. gadā)

Salīdzinājumā ar Latviju darba intensitāte ASV, Lielbritānijā un Vācijā intervijās raksturota kā ievērojami lielāka, jāstrādā ir daudz vairāk. Papildu grūtības rada tas, ka informanti ir iemācījušies noteiktas lietas darīt atškirīgā veidā, īpaši tas attiecas uz to, kā rakstīt un kā sevi pasniegt. Viens remigrants no ASV šo situāciju raksturo kā sevis laušanu: “[..] tā sevis laušana visu laiku, lai sevi pasniegtu visu laiku tādā pareizā veidā, [..] kas tev prasa, protams, ilgāku laiku nekā tiem, kas tai vidē ir izauguši”. Vienā no intervijām atklājas, ka arī Lielbritānijā dzīvojot iegūtā izglītība un darba pieredze var nebūt pietiekama, lai gūtu sasniegumus Lielbritānijas metropolē Londonā, jo ārpus Londonas iegūtā pieredze netiek augstu vērtēta:

"Viena no Anglijas niansēm ir tāda, ka principā tas, ko tu esi darījis ārpus Londonas, citur Anglijā, neskaitās.” (9. Vĩrietis, 35 gadi, IT, Lielbritānija, emigrējis 2011. gadā)

Daudzos gadījumos jau pirms emigrācijas augsti kvalificētie Latvijas emigranti apzinājušies, ka emigrācijas valstī, īpaši Lielbritānijā vai ASV, nacionālās un lokālās īpatnības ḷoti atšḳiras no citur iegūtās pieredzes, tādēḷ pirmie emigrācijas gadi veltīti, lai izprastu vietējo kontekstu. Vairāki informanti atzīst, ka vietējās situācijas labāka pārzināšana ir arī galvenais, kas atšḳir vietējos speciālistus no iebraucējiem, tādēl viṇi labprāt atbalsta citus Latvijas emigrantus, lai paskaidrotu vietējās situācijas vai sistēmas īpatnības. Tas citiem Latvijas emigrantiem var mazliet atvieglot adaptāciju jaunajā mītnes valstī:

"Viennozīmīgi ir skaidrs, ka cilvēkiem, kas ir auguši uz vietas, ir diezgan lielas priekšrocības, jo viṇi zina sistēmu. Viṇi zina sistēmu no A līdz Z, vinniem daudzas lietas nav jāuzmin. Es tāpēc labprāt palīdzu jaunajiem ārstiem, kas uz šejieni atbrauc, jo zinu, cik man pašam bija sarežğīti, jo es nezināju to, ko cilvēki tur uz vietas tāpat zina." (8. Vìrietis, 48 gadi, ārsts, Lielbritānija, emigrējis 2005. gadā) 
Intervijās augsti kvalificētie Latvijas emigranti atzīst, ka patiešām labam speciālistam lielākoties nav grūti atrast darbu ārzemēs, bet ievērojami sarežḡītāk ir konkurēt ar vietējiem profesionāliem, lai ien̦emtu vadošu amatu:

"Kultūras atšķirības. Tā ir ḷoti liela un bieza siena, kurai ir jātiek cauri. Pašā sākumā tas ir ārkārtīgi grūti. Diemžēel šì kultūra ir tāda, kas iekšā nelaiž. Tajā brīdī, kad tu esi iekšă, tad ir vienkārši jānoturas. [..] Viṇi nodrošina to, lai savējie tiktu vadošās pozīcijās. Tie, kas zem viṇiem, vairs nav tik svarīgi, jo viṇi tiks vadīti. Bet - jo tu augstāk vēlies kāpt, jo tā siena ir daudz grūtāka. [..] Anglis vienmēr vairāk atbalstīs angli. Lai tu būtu šai vidē, tev ir l̦oti, l̦oti jāpielāgojas. Uzvedības ziņā, attieksmes ziṇā. [..] Tā pārākuma sajūta ir jūtama l̦oti bieži. Netieši.” (5. Sieviete, 40 gadi, specializācija ekonomikā un uzñēmuma vadīšanā, Lielbritānija, emigrējusi 2008. gadā)

Atsevišḳās intervijās informanti, kas bija mazāk apmierināti ar profesionālo karjeru uzṇemošajā valstī, lieto emocionālākus un radikālākus apzīmējumus, lai raksturotu pieredzi Lielbritānijā un Norvēǵijā. Piemēram, aprakstot vietējo attieksmi pret imigrantiem, izmantoti tādi apzīmējumi kā "kastu sistēma" un "rasisms”. Tiek norādīts - lai integrētos uzṇemošajā valstī, ir nepieciešams mainīt savu vārdu un uzvārdu, lai tas būtu raksturīgs uzṇemošajai valstij:

"Es meklēju darbu arī mārketingā, bet, lai tur dabūtu darbu, ir jāmaina vārds un uzvārds. [..] Tāpēc, ka norvēgi bīda savējos. Tādos mazkvalificētos darbos viṇi ḷoti labprāt ṇem ārzemniekus, bet tādos augsti kvalificētos viṇi ņem tikai savējos. Lai būtu norvēga vārds un uzvārds. Es zinu daudzus tādus gadījumus, kad latvieši nomaina savu vārdu un uzvārdu, lai izklausītos pēc norvēgiem, ja grib labāku darbu. [..] Tāpat kā briti ir rasisti, kur ir kastu sistēma, arī Norvēgijā ir kastu sistēma.” (36. Sieviete, 42 gadi, publiskās attiecības, Norvēgija, emigrējusi 2006. gadā, atgriezusies 2017. gadā)

Intervijās raksturotas arī personības īpašības, kas nepieciešamas, lai iekḷautos uzṇemošajā valstī. Piemēram, norādīts, ka adaptācijas priekšnoteikums ir atvērtība visam jaunajam, gatavība mainīt savus priekšstatus un ikdienas rutīnas:

"Vispār cilvēkam pašam jābūt atvērtam, nedrīkst ierauties sevī, savā čaulā, savos aizspriedumos. Tad arī var iedzīvoties. Jāiet ar acīm un ausīm val̄ā, jāskatās, kā viṇi dzīvo, un tas jāpieṇem. Ne jau varbūt viss, bet tas, kas nepieciešams, lai iekḷautos.” (30. Sieviete, 46 gadi, tulce un projektu vadītāja, Vācija, emigrējusi 1996. gadā) 
Vairāki informanti norādījuši, ka valodas izjūtas apguvei nepieciešams apmēram gads, un līdzīgi arī adaptācija jaunajā vidē daḷai informantu aizṇem apmēram gadu. Augsti kvalificēto Latvijas emigrantu adaptācijas pieredzes atškiriras, tomēr vairākās intervijās izskan apzīmējums "lūzums”, kas raksturo to, ka jaunā situācija tiek pieņemta bez idealizācijas un mainoties pašam atbilstoši uzṇemošãs valsts kontekstam:

"No savas pieredzes, pirmais gads ir tāda sajūta, ka tu emocionāli nomirsti. Ir jānotiek lūzumam, un vai tu tam tiec pāri vai nē. Tas ir pilnīgi visiem. Valodu un visu citu tu vari apgūt Latvijā. Bet vai tu šeit pien,emsi... Tu nevari palikt ar tādu pašu domāšanu un mentalitāti kā Latvijā. Man pilnīgi bija tāda sajūta. Tu atbrauc. Sākumā ir eiforija. O! Šeit būs forši. Tad sākās realitāte, pa pilienam, pa pilienam viss sakrājas, tad notiek lūzums, tu tur izraudies. Katrs to izdzīvo savādāk. Tad tu sāc atdzimt no jauna. Pieṇemt to. Pakāpeniski, pakāpeniski. Tas ir apmēram gads. Un tas ir pilnīgi visiem. Tad, kad tu atbrauc uz Latviju, tu jau skaties uz visu pilnīgi citām acìm. Bet tas ir tikai pateicoties tam, ka tu to esi sevī iekšā jau visu izdzīvojis. Es nezinu, vai mazāk kvalificētiem tas ir savādāk, bet ārstiem un juristiem vadošās pozīiijās tā ir. Bet tas arī l̦oti palīdz." (32. Sieviete, 40 gadi, ārste, Norvēgíja, emigrējusi 2012. gadā)

Vairākās intervijās, raksturojot atšḳirīgo pieredzi gan Vācijā, gan Norvēǵijā un Lielbritānijā, informanti izmanto jēdzienu "mentalitāte” un runā par atvērtu vai slēgtu mentalitāti, kas iebraucējus nepieṇem, vai par atšḳirībām pasaules uztverē:

"Vienkāršsi tāpat šeit iekḷūt ir l̦oti, l̦oti sarežgīiti. [..] Jo Norvēgijā ir tā, ka viṇi svešus nepieṇem. Ir l̦oti grūti kādu atlaist, tādēḷ viṇi pien,em caur paziṇām. Viṇiem arī mentalitāte nav tik atvērta, viṇi pārbauda cilvēku piecas reizes, pirms laiž sev tuvumā. Man l̦oti paveicās." (32. Sieviete, 40 gadi, ārste, Norvēgija, emigrējusi 2012. gadā)

Informanti no Vācijas un Norvēgiijas intervijās uzsver, ka ḷoti būtiskas ir mītnes valsts valodas zināšanas augstākajā līmenī. Lai ieņemtu vadošu amatu lielā uzṇēmumā, mītnes valodas zināšanām ir jābūt bez akcenta:

"Es biju normāls darbinieks, normāls cilvēks, varēju vairāk virs vidējā saņemt. Protams, menedžeru līmenis ir cits līmenis. Es tur arī nevarētu ielēkt, jo nav tik labas valodas zināšanas, nav vietējās zināšanas, tas nebūtu īsti reāli." (35. Vìrietis, 52 gadi, IT, Norvēgiija, emigrējis 2010. gadā, atgriezies 2013. gadā) 
Vairāku intervēto augsti kvalificēto Latvijas emigrantu pieeja darba tirgum ārvalstīs ir bijusi vispirms iegūt augstāko izglītību uzṇemošajā valstī. Pēc augstskolas beigšanas viṇi jūtas labāk sagatavoti darba tirgum, jo augstskolās daudzās jomās ir paredzēta prakse un tiek meklētas prakses vietas, kas l̦auj izveidot kontaktus un saprast vietējā darba tirgus īpatnības:

"Viss sākās ar praksi. Universitātē vajadzēja meklēt prakses vietu. Piesēdos pie interneta un meklēju. Salīdzinot ar Latvijas websaitiem, Vācijā ir viss skaidrs, kur un kādus darbiniekus meklē. Aiziet uz jebkura uzṇēmuma lappusi, l̦oti ātri var visu atrast. [..] Rakstīju CV un tā arī caur internetu atradu. Pēc universitātes beigšanas es apsēdos un izdomāju, uz kādu pilsētu es braukšu. Es nolēmu - uz Berlīni, jo Berlīne ir liela, internacionāla, ar startapiem. Tad vienkārši sūtīju savus CV, man liekas, kādus 60-70 CV izsūtīju. Man bija daudz pārrunas. Es pārbraucu uz Berlīni, jo viṇi arī apmaksā pārbraukšanu. Ja uzaicina uz pārrunām, man arī cel̦u samaksā. Man kā studentei nevajadzēja krāt naudu, lai brauktu uz pārrunām. Viss l̦oti ātri. Protams, arī draugi palīdzēja pārbraukt. Bet visa tā meklēšana ir caur internetu. Vienkārši vajag zināt, kādā jomā es vēlos, un meklēt, meklēt, meklēt." (21. Sieviete, 39 gadi, IT, Vācija, emigrējusi 2004. gadā)

\section{IEDZĪVOŠANĀS UN STABILITĀTE: VALODAS APGUVE UN VIEDOKLIS PAR} PIEN̦EMŠANU VAI NEPIEN,EMŠANU MĪTNES ZEMË

Apgūt un pilnveidot valodas prasmes augsti kvalificētie Latvijas emigranti uzṇemošajā valstī turpina arī pēc divdesmit gadiem emigrācijā, jeb, citiem vārdiem, tas ir nebeidzams process. Ilgāk dzīvojot emigrācijā, Latvijas emigranti apgūst dažādus valodas kalambūrus, idiomas un izteicienus, kas palīdz viniiem labāk izprast un uztvert vietējos un darbā uzturēt sarunas. Tomēr pirmās paaudzes emigrantam ir gandrīz neiespējami pilnībā integrēties mītnes zemē:

"Ar to ir jāizaug. Tie vietējie teicieni un izteicieni, tās paražas un tā izturēšanās. Tas, kā notiek informācijas apmain,a. Ja tu kā ārzemnieks mēgini iefiltrēties šajā vidē, nepārtraukti ir cīṇa, jo ir loti grūti vispār saprast, ko viṇi ar to domā. Man ir l̦oti laba valoda jau gadus divdesmit, bet ar to nepietiek.” (5. Sieviete, 40 gadi, specializācija ekonomikā un uzn̄êmuma vadī̌anā, Lielbritānija, emigrējusi 2008. gadā)

Noteiktās jomās valodai komunikācijā ar klientu ir l̦oti liela loma, tādēl Latvijas emigranti strādā ar savu izrunu un cenšas mazināt akcentu vai latviešiem raksturīgās runas īpatnības. Piemēram, latviešu ārsts ASV izmantojis 
runas konsultanta pakalpojumus, lai mazinātu "austrumeiropieša akcentu”. ASV kontekstā nozīme adaptācijā ir arī ādas krāsai, un "baltais” imigrants atrodas salīdzinoši labvēlīgākā situācijā nekā spāṇu izcelsmes migranti:

"Kaut kādā lìmenī aizspriedumi ir vienmēr, bet l̦oti palīdz tas, ka esmu "baltais" [pasmejas]. Cilvēkiem patīk mans akcents, bet, protams, vērtē tavas darbības. Savā laikā esmu pan̄ēmis treninu, lai balss neskanētu tik kategoriski austrumeiropeiski. [..] Bet visnotal cilvēki pamana, ka neesmu vietējais. Tomēr īpaši lielajās pilsētās cilvēki ir pie tā ḷoti pieraduši. [..] Katrā ziṇā ir liela kultūras barjera, arī iekšêji psihologiski nejūtos kā amerikānis un nekad arī nejutīšos." (20. Vïrietis, 48 gadi, ārsts, ASV, emigrējis 1997. gadā)

Intervijās parādās dažādas nostādnes, vai attieksme pret Latvijas emigrantiem ir diskriminējoša. Viena no pozīcijām ir tāda, ka attieksme ir līdzīga un nekāda diskriminācija nav vērojama. Atšķirība izpaužas vien̄̄gi tajā ziṇā, ka imigranti valodas ierobežojumu dēḷ nav tik pārliecināti par sevi:

"Nav atšķirības ne algas ziṇā, ne attieksmēe. Varbūt vienīgi, ja ietu uz kādām l̦oti augstām vadošām pozīcijām. Es neredzu atšķirību starp vācieti un sevi. Varbūt drīzāk pietrūkst tās pašpārliecinātības. Jo vāciski runā vēl drusku ar kḷūdām, ne tā kā vācietis. Tas ir vienīgais. Atšķirības nav. Es savā attīstībā nevaru pamanīt šādas atšķirības.” (21. Sieviete, 39 gadi, IT, Vācija, emigrējusi 2004. gadā)

Vairākās intervijās izskan aicinājums nepakḷauties stereotipam, ka mītnes zemes valstī labu darbu var atrast tikai vietējie. Augsti kvalificētie migranti stāsta par savu pieredzi, kas apgāž šādus stereotipus:

“Tas ir pašam tāds uzstādījums: "Es jau te darbu nedabūšs, norvēgi pien,em tikai savējos.” Te nu es sēžu, pien,emta divas reizes darbā, un uz pirmo vietu bija 181 kandidāts, un uz otro 79. Starp visiem norvēgiem es dabūju darbu. Daudz vienkāršāk ir norakstīt to, ka nekas neiet, uz to, ka esmu no Austrumeiropas, un beigās tu pats arī panāc to. Savā ziṇā tu atrodi tieši to, ko meklēe." (37. Sieviete, 43 gadi, administratīvā konsultante, Norvēgija, emigrējusi 2002. gadā)

Intervijās izskan viedoklis, ka priekšstats par diskrimināciju pret imigrantiem un iebraucēju nepieņemšanu ir dzīvs tādā nozīmē, ka paši imigranti noskaṇojas visās neveiksmēs vainot diskrimināciju, bet tas bieži vien neatbilst realitātei, jo diskriminācija ir tikai imigrantu galvā: 
"Vai Zviedrijā esat jutusi atšķirīgu attieksmi tāpēc, ka esat no Latvijas? Ir bijusi kāda negatīva attieksme, aizspriedumi vai stereotipi?

Nē, manuprāt, tas katram pašam ir galvā. Ja cilvēks iedomājas, ka pret viṇu būs aizspriedumi, tad viņš arī tos aizspriedumus pret sevi rada. [..] Neuzskatu, ka Zviedrijā pastāv kāda veida diskriminācija. Ja cilvēks vēlas strādāt, viņam ir visas iespējas, bet, ja kāds domā, ka neko nevar un ka vinu visi diskriminē, tad vinnš tiešām neko nevar.” (46. Sieviete, 43 gadi, uzṇēmuma vadītāja, finanšu konsultante, Zviedrija, emigrējusi 1996. gadā)

Vienlaikus ir arī citas pieredzes, kad novērotas būtiskas attieksmes atškirības ārzemnieka statusa dēḷ. Piemēram, viens no intervijas dalībniekiem kā students Vācijā izjutis ḷoti atšḳirīgu attieksmi, jo bija ārzemnieks:

“Tiek l̦oti preferēts vācietis, ārzemju studenti tiek nolaisti zemāk kaut kādā pakāpē. Es biju no šiem ārzemju studentiem, iespējams, pašā augstākajā pakāpē, jo es pierādīju kaut ko, ko tie vācieši negaidīja. Bet tik un tā vienmēr šī hierarhija, loti stipra.” (23. Vĩrietis, 43 gadi, matemātiḳis-statistiḳis, Vācija, emigrējis 2002. gadā, atgriezies 2007. gadā)

Vienā gadījumā grūtības atrast augstākas kvalifikācijas projektu vadītāja darbu Norvēǵijas uzṇēmumā sekmēja to, ka emigrants no Latvijas nolēma meklēt partnerus un veidot pats savu uzṇēmumu. Viṇa biznesa partneris un uzṇēmuma līdzīpašnieks ir norvēgis - tas atvieglo komunikāciju ar norvēǵiem, un šāds tandēms ir sekmīgs biznesa modelis Norvēǵijas vidē:

“Es domāju, ka viṇi [uzṇêmumā, kurā iepriekš strādāja] kaut kādā ziņā sāka izmantot to, ka es neesmu norvēgis [uzdeva darbietilpīgākus un mazāk atalgotus uzdevumus]. Lai kā es esmu varbūt gudrāks vai labāks, bet... Ja tu neesi norvēgis, tad tu neesi norvēgis. [..] Mēs esam tomēr iebraucēji, un, blakus stāvot, būs tā atšķirība. [..] It kā nauda ir, CV ir foršs, tu it kā vari atrast labu darbu, bet tu esi latvietis. Lai kāds tas tavs CV, tikt par projekta vadìtāju nav viegli. [..] Pirms tam jau bija izveidojusies sadarbība ar vienu no maniem klientiem, kurš tagad ir mans biznesa partneris. Mēs sākām jau iepriekš veidot tādu kā biznesiṇu. [..] Man vajadzēja norvēgí, kurš man palīdzēs kontaktēties ar klientiem, kuram ir savi kontakti.” (40. Vìrietis, 37 gadi, uzṇēmuma vadītājs, Norvēgija, emigrējis 2014. gadā)

Citā gadījumā attieksmes atšḳirības vērojamas saistībā ar organizāciju, kuru Latvijas emigrants pārstāv kādā pasākumā. Piemēram, pārstāvot augsta ranga pētniecisko organizāciju no Vācijas vai Latvijas Universitāti, kolēǵu attieksme ir pilnīgi atškirīga: 
"Konferencē vai starptautiskā izstādē ir dalībnieka vārds, uzvārds un no kurienes. Ja ir rakstīts Maksa Planka institūts Minhenē, tad uzreiz ir interese un laba attieksme. Bet, ja ir rakstīts Latvijas Universitāte, tad: "Nav laika. Jūs tāpat no mums neko nepirksiet." Cilvēki skatās uz universitātēm, kurām ir vārds. Ir universitāšu reitingi, cik projektus vinnē." (28. Vīrietis, 46 gadi, fiziḳis, Vācija, emigrējis 2004. gadā, atgriezies 2013. gadā)

Intervijās izskan arī viedoklis: ja salīdzina uzṇemošās valsts iedzīvotājus ar latviešiem, var secināt, ka tur cilvēki ir ievērojami iecietīgāki un daudz vieglāk pieṇem citādo. Piemēram, norvēǵi raksturoti kā tolerantāki par latviešiem, vienlaikus atzīstot, ka atškirīīgās dzīves pieredzes traucē adaptēties:

"Es domāju, ka norvēgu attieksme ir tolerantāka un labāka nekā mūsu attieksme. Mēs esam tajos izteikumos kategoriskāki, pret krieviem un visādiem citiem, mēs esam rasistiskāki nekā viṇi. Cik es esmu saskāries, viṇi ir ḷoti atvērti, l̦oti pozitīvi, bez aizspriedumiem, tāpēc ka es esmu no kaut kurienes, no šejienes. Cita lieta, kam nevar tikt pāri, viṇiem ir cita pagātne, viṇiem ir cita valoda, cita kultūra, kuru tu nezini.” (35. Vìrietis, 52 gadi, IT, Norvēgíja, emigrējis 2010. gadā, atgriezies 2013. gadā)

IEDZIVIOŠANĀS UN STABILITĀTE: IESPĒJA VAIRĀK SADARBOTIES AR LATVIJU UN IZMANTOT LATVIJĀ IEGŪTO KULTŪRAS KAPITĀLU

Intervijās iegūtā informācija parāda, ka Latvijas kultūras kapitālu (latviešu valodu, Latvijai specifiskās zināšanas, piemēram, likumdošanas jomā, Latvijas kontaktus) emigranti pielieto lielākoties tajā posmā, kad ir notikusi adaptācija un iedzīvošanās mītnes valstī. Tad, kad emigranti ir apguvuši mītnes zemes īpatnības un mītnes zemē kaut ko sasnieguši profesionālajā jomā, viṇi var saskatīt iespējas, ko dod arī Latvijas zināšanas un kontakti. Daži no piemēriem ir saistīti ar biznesa izveidošanu, kas sniedz pakalpojumus Latvijas emigrantiem vai Latvijas preču eksportētājiem. Tas attiecas uz tādām jomām kā bizness, finanses, vadība un IT. Piemēram, juridiskos un grāmatvedības pakalpojumus latvieši Norvēǵijā var sniegt tikai tad, ja labi pārvalda gan Latvijas, gan Norvēgijas normatīvo regulējumu un latviešu un norvēǵu valodu:

"Sākotnēji jau laiks pagāja apmācībā, jo iepriekšējās pieredzes nebija. Gan sapratne, gan specifiskā terminologija. Viss tas bija jāapgūst. Pamazām to apgūstot, viss iestrādājās. Sāka veidoties latviešu klientu portfelis. Daudzi latvieši tur nodarbojas ar visādām lietām, kur arī šādi pakalpojumi nepieciešami, pārsvarā jau būvniecībā. Tad jau logiiski veidojas tā saikne 
grāmatvedības un konsultāciju jautājumus pārrunāt un risināt dzimtajā mēlē." (31. Vìrietis, 35 gadi, finansists-grāmatvedis, Norvēgija, emigrējis 2011. gadā, atgriezies 2018. gadā)

Līdzīgi arī biznesa konsultanti Zviedrijā, Lielbritānijā vai Vācijā savus pakalpojumus kvalitatīvi var sniegt tikai tad, ja labi pārvalda uzṇēmējdarbības vidi gan Latvijā, gan konkrētajā mītnes zemē:

"Zviedrijā ir liela latviešu kopiena, un daudz jaunu cilvēku brauc uz Zviedriju no Latvijas. Redzot, ka daudziem uzṇēmējiem nav skaidrs, kā tur notiek uzṇēmējdarbība, vēlējos kaut kā palīdzēt. No sākuma palīdzēju brīvprātīgi, taču, tā kā tas ir diezgan apjomīgs darbs, izdomāju, ka tas varētu būt labs bizness. [..] Es jau vairāk nekā 20 gadus dzīvoju Zviedrijā, tādēḷ pārzinu visus sīkumus. Tā ir tā mana konkurences priekšrocība." (46. Sieviete, 43 gadi, starptautiskais bizness, Zviedrija, emigrējusi 1996. gadā)

“Tas, ko mēs darām, ir eksporta konsultācijas. Tie ir tirgus pētījumi, bet galvenais mūsu fokuss ir uz partneru piesaisti. Mūsu klientu grupa ir mazie un vidējie uzñēmumi. Šobrīd mūsu galvenā klientu grupa ir Latvijas jeb Baltijas uzn̄ēmumi.” (4. Sieviete, 36 gadi, starptautiskais bizness, cirkulārā migrācija, Vācija un Lielbritānija)

\subsection{LATVIJAS UN ĀRVALSTU PIEREDZES SALITDZINĀJUMS}

Salīdzinot pieredzi Latvijā un ārvalstīs, interviju dalībnieki atsaucas katrs uz savu konkrēto dzīves pieredzi un emigrācijas motivāciju. Tie, kas aizbraukuši uz ārzemēm kādā augstākās izglìtības ieguves posmā, salīdzina izglītības pieredzi Latvijā un tajā valstī, kurā mācījušies. Piemēram, viens no interviju dalībniekiem, kurš strādā Zviedrijā, bet mağistra grādu ieguvis Dānijā, atzīmē, ka Dānijā mācību programma ir daudz interesantāka, praktiskāka un vērsta uz studenta izvēlēm. Vairāki interviju dalībnieki norāda, ka ārvalstu augstskolās ir interesantāk mācīties:

"Studēt Oslo Universitātē bija ārkārtīgi interesanti. Man ir iespēja salīdzināt ar Lauksaimniecības universitāti, un diemžēe jāsaka, ka tā ḷoti atpaliek tajā ziṇā, kā mācības tiek organizētas. Tas, ko tur mācījos, ielika tādu kā fundamentu. Iedeva pašapziņu, ka neesmu sliktāka, ka varu.” (37. Sieviete, 43 gadi, administratīvā konsultante, Norvēgija, emigrējusi 2002. gadā) 
Vairākos gadījumos pirmā ilgākā pieredze ārvalstīs izmaina dzīves uztveri un turpmākos plānus, atklājot dažādas jaunas iespējas, par kuru esamību emigrants iepriekš nemaz nav nojautis:

"Ja pirms tam bija tāda l̦oti skaidra ideja par to, kā dzīve tālāk varētu iet, pabeidzot universitāti un iegūstot praksi, darbu, draudzeni, suni, dzīvokli, tad ERASMUS to visu izmainīja. Tas bija kā āḳis lūpā, ka ārpusē ir ḷoti interesanti, ka tev ir daudz un dažādas kultūras apkārt, kas būt̄̄bā izaicina visu, ko tu uzskati par normālu, bet tas ir tik interesanti, ka gribas to iepazit." (17. Vìrietis, 30 gadi, IT jaunuzn̄ēmumi, ASV, emigrējis 2008. gadā)

“Atbraucu ar domu, ka es gadu pastrādāšs, jo tā arī es Latvijā domāju. Es nemaz nedomāju, ka es palikšu. Man varbūt vajadzēja sevi pierādīt, man vajadzēja redzēt citus apstākḷus, man vajadzēja izlauzties kaut kur ārā. Man vajadzēja kaut ko citu, bet es nebūt nebraucu projām pavisam. Es braucu ar tādu lozungu, ka es aizbraukšu uz gadu pastrādāt Norvēgijā, tad jau redzēs.” (39. Vìrietis, 58 gadi, ārsts, Norvēǵija, emigrējis 1992. gadā)

Kāds cits iespēju studēt ārvalstīs ir mērḳtiecīgi meklējis, lai paplašinātu savu zināšanu apvāršṇus un padzị̣ināti apgūtu citās universitātēs īstenotos pētniecības virzienus:

“Tad kaut kādā brīdī man radās vēlme aizbraukt uz ārzemēm un pamācīties kaut ko tādu, ko es nevaru iemācīties Latvijā. [..] Līdz ar to es kādā brīdī sajutu, ka visu, ko es Latvijā varēju apgūt, es esmu apguvis. Man gribējās kaut kur uz ārpasauli. Es aizrakstīju uz vairākām universitātēm, pieteicos." (12. Vìrietis, 47 gadi, zinātnieks matemātiḳis, ASV, emigrējis 1997. gadā, atgriezies 2007. gadā)

Aizbraucot un iegūstot pieredzi citā valstī, cilvēks labāk var saprast, ko tieši viṇš vēlas darīt un kā tālāk dzīvot. Vairāki intervētie zinātnieki atzīst, ka viṇiem iespējas izpausties zinātnē Latvijā ir mazākas, nekā dzīvojot ārvalstīs. Toties Latvijā ir labākas iespējas pašam attīstīt jaunu darbības virzienu, vadīt kādu projektu, nevis būt skrūvītei lielā sistēmā:

"Vislabākais ir aizbraukt un izjust, pamācīties, iegūt labas zināšanas, paskatīties pasauli, sajust sevi, kas pašam patīk. Man bija pilnīgi skaidrs pēc pieciem gadiem, ka es gribu būt Latvijā un nekur vairs negribu braukt, ja būs jebkāds darba piedāvājums, mani neinteresēe. Protams, ka man nav tās iespējas izpausties zinātniski. To, ko es potenciāli varētu darīt ar savu galvu, 
to es nevaru darīt šeit, tas ir skaidrs. Man ir ierobežotas iespējas. Es darbojos ar lekcijām, pārsvarā ar studentiem, nevis zinātnisku darbu. Bet visam ir savi mīnusi un plusi. Ja es gribētu strādāt un izmantot savu zinātnisko potenciālu, es strādātu Kembridžā vai kaut kur. [..] Es tikai varu pateikt, ka Vācijā viss ir l̦oti, l̦oti sakārtots, viss ir izdomāts. Tur katra skrūvīte ir savā vietā. Atalgojumi ir lieli. Algas ir labas. Ne par ko nav jārūpējas. Mēs nevaram salīdzināt Latvijas vidi ar Vācijas vidi, to nemaz nevajag darīt. Tas arī nemaz nav izdarāms. Tas ir normāli. Ir jāsaprot, ka ir atšķirības. Ir lielas valstis, ir mazas valstis. Tur ir pavisam cita sistēma - tu esi maza skrūvīte milzīgā sistēmā, šeit tu atbrauc un esi pirmais puisis visā ciemā.” (23. Vìrietis, 43 gadi, matemātiḳis-statistiḳis, Vācija, emigrējis 2002. gadā, atgriezies 2007. gadā)

Aizbraukušajiem ārstiem motivāciju emigrēt nosaka gan vēlme apliecināt sevi ārvalstīs, sasniegt kaut ko augsta līmeṇa specializētās universitāšu slimnīcās, gan arī neapmierinātība ar veselības aprūpes sistēmā valdošo kārtību un attieksmi pret jaunajiem ārstiem. Piemēram, iespēja strādāt specializētā augsta līmeṇa klīnikā Zviedrijā vai Vācijā nav salīdzināma ar Latvijas iespējām:

"Bija iespēja darīt zinātnisko darbu l̦oti augstā līmenī. Tã ir viena no centrālajām Skandināvijas universitāšu slimnīcām, varbūt pat viena no pazīstamākajām pasaulē. Klīniski strādāt tādā līmenī, kura Latvijā laikam vēl ilgi nebūs, arī diez vai citur Skandināvijā tāds varētu būt. Protams, Skandināvijā ir universitātes slimnīcas, kur var darīt to pašu, bet tur ir visas iespējas, sākot ar onkologiju un beidzot ar visikdienišķāko ikdienas traumatologiju. Tur ir viss spektrs. Faktiski tas ir tas arguments. [..] Latvijā toreiz nebija tādas iespējas. Ja godīgi, tad nav arī tagad.” (47. Vìrietis, 59 gadi, ārsts, Zviedrija, emigrējis 1992. gadā)

Cits no Latvijas emigrējis un pēc tam atgriezies ārsts norāda, ka viņam viens no galvenajiem iemesliem emigrēt bijusi neapmierinātība ar Latvijā pastāvošo attieksmi pret jaunajiem ārstiem un grūtībām veidot savu karjeru Latvijā:

"Viens no iemesliem, kāpēc es aizbraucu no Latvijas prom, jo manā gimenē es esmu pirmais ārsts. Man nav tur iemīts celiṇš, ka man būtu vectēvs Stradiṇš un tagad es esmu Ërglis. Ja tev nav kaut kāda konkrēta iemīta hierarhija Latvijas medicīnā, tad tev, protams, tā visa Latvijas medicīnas sistēma ir tāds liels izaicinājums, lai atrastu savu vietu. Es aizbraucu, jo es neredzēju, ka ārstiem l̦oti patiktu nodot savas zināšanas pārējiem, ātri iesaistīt darbā un veidot labāku veselības sistēmu. Tieši otrādāk - tur ir acīmredzami 
izveidojušās dinastijas, un, protams, tiem celiņ̌̌ ir vieglāks. Un tas man īsti nepatika." (22. Vìrietis, 37 gadi, ārsts, Vācija, emigrējis 2011. gadā, atgriezies 2019. gadā)

Par Latvijas medicīnas izglītības kvalitāti kopumā emigrējušie ārsti izsakās pozitīvi. Tā ir konkurētspējīga, un par savām zināšanām viṇi nekaunas, tomēr norāda, ka Latvijā nepietiekama uzmanība pievērsta praktisko iemaṇu apgūšanai:

"Medicīniskā pamatizglītība Latvijā ir OK. Bet praktiskā puse Latvijā ir loti vāja. Medicīnā ḷoti daudzas lietas ir praktiskas.” (32. Sieviete, 40 gadi, ārste, Norvēgija, emigrējusi 2012. gadā)

Attiecībā uz darba vidi Latvijas emigranti atzīst, ka tādās valstīs kā Lielbritānija, Zviedrija, Norvēǵija un Vācija darba attiecības ir salīdzinoši daudz sakārtotākas, darba algas katrā līmenī ir skaidri noteiktas, un par augsti profesionālu darbu tiek saṇemts l̦oti labs atalgojums. Darba attiecību hierarhija ir skaidrāka, un nav tādu neproporcionālu atalgojuma atškirību starp vadošo personālu un speciālistiem, kāds vērojams Latvijas augstskolās un slimnīcās. Arī darba rutīna ir daudz skaidrāka, un tas būtiski atvieglo dažādas situācijas:

"Šeit viss ir daudz horizontālāk. Te nav piramīdas struktūra, kur iestādes

vadītājs var ar vienu vēzienu atlaist vai pieņemt darbinieku. Šeit struktūra ir daudz horizontālāka. Var just, ka te jau dokumentos un darba rutīnās ir iestrādātas vērtības, par kuru eksistenci tu nemaz nenojauti. Piemēram, dzimumu līdztiesība vai iespēja ietekmēt lēmumus. Tas ir mehānismos iestrādāts, ka tas darbojas ikdienā." (42. Vīrietis, 37 gadi, arhitekts, pasniedzējs, Zviedrija, emigrējis 2016. gadā)

"Zviedrijā profesionāli viss ir l̦oti reglamentēts. Ir l̦oti skaidras amata prasības, pienākumi, un struktūra ir l̦oti labi aprakstīta. Viss ir skaidrs." (45. Vìrietis, 35 gadi, uzṇēmējs būvniecībā, Zviedrija, emigrējis 2013. gadā)

\section{SECINĀJUMI}

Šajā nodaḷā galvenā uzmanība pievērsta augsti kvalificētu Latvijas emigrantu adaptācijas stratēǵijām dzīvei ārvalstīs. Tās aplūkotas kontekstā ar emigrācijas motīviem, diskriminācijas pieredzi un mācību un darba salīdzinājumu Latvijā un ārvalstīs. Padziḷinātās intervijas ar augsti kvalificētiem Latvijas emigrantiem atklāj, ka dažādiem migrācijas posmiem raksturīgas 
dažādas adaptācijas stratēgiijas, bet mītnes zemes valodas apguve pirmās paaudzes migrantiem ir aktuāla visos posmos. Kopumā var nošḳirt pirmsmigrācijas adaptācijas stratēǵijas, pārejas posma adaptācijas stratēǵijas uzreiz pēc migrācijas un sākotnējās iedzīvošanās laikā, kā arī iedzīvošanās un stabilitātes posmam raksturīgās adaptācijas stratēǵijas.

Tie Latvijas emigranti, kas uzṇemošajā valstī plāno iegūt augstskolas diplomu, pirmsmigrācijas posma laikā iegūst informāciju par dažādām augstskolām un to piedāvātajām mācību programmām, par nosacījumiem saistībā ar iestājeksāmeniem, mācību maksu un stipendijas iespējām. Pēc lēmumu pieņemšanas tiek nosūtīti pieteikumi un kārtoti eksāmeni. Citiem migrantiem pirmsmigrācijas sagatavošanās stratēǵijas ḷoti atškiras dažādās nozarēs. Daudzos gadījumos būtisks nosacījums ir kontaktu izveidošana un rekomendāciju sagatavošana. Tās ir galvenās sagatavošanās stratēǵijas paralēli valodas zināšanu un profesionālo iemaṇu pilnveidei.

Attiecībā uz sākotnējās iedzīvošanās posmu padziḷinātās intervijas ar augsti kvalificētiem Latvijas emigrantiem atklāj, ka daudziem šajā posmā ir vairāk vai mazāk institucionalizēts mācekḷa vai praktikanta statuss, kas vienlaicīgi ir pārbaudes laiks konkrētajā darbavietā. Tas zināmā mērā attiecas arī uz ārstiem rezidentūrā, jo viṇu darbu uzrauga pieredzējušie ārsti, kā arī uz jaunākajiem darbiniekiem IT un finanšu jomā. Dažos gadījumos mācekḷa posms iekḷauj organizētu apmācību, bet ne vienmēr. Dažkārt pielāgošanās jaunajai videi un darba prasībām notiek pašmācības ceḷā vai lūdzot atbalstu vecākiem kolēǵgiem. Šajā posmā augsti kvalificētie Latvijas emigranti pielāgo Latvijā iegūtās zināšanas un prasmes jeb kultūras kapitālu mītnes valsts darba devēju prasībām. Raksturīgi, ka šajā laikā speciālistu algas ir zemākas, darba pienākumi nepatīkamāki un laikietilpīgāki, un darbs aizṇem lielāko dąu laika, jo nepieciešams pilnveidot zināšanas arī pēc darba dienas beigām un brīvdienās. Sākotnējās iedzīvošanās posmā augsti kvalificētie Latvijas emigranti apgūst sevis pasniegšanas prasmes un daudzi cenšas mācīties no citiem, kā pareizi runāt ar kolēgiiem un klientiem, kā veidot savu tēlu, kā parādīt darba devējam sevi izdevīgākā gaismā.

Nostabilizēšanās un iedzīvošanās mītnes valstī raksturīga ar to, ka noteiktu darba uzdevumu veikšanā ir izveidojusies rutīna, kas l̦auj ietaupīt laiku. Parādās iespēja izvērtēt turpmāko karjeru (meklēt citu, piemērotāku darbu) vai attīstīt paralēlus projektus, piemēram, sadarbībā ar Latviju. Šajā posmā augsti kvalificētie speciālisti, kuriem ir interese sadarboties ar Latviju, aktivizē savu darbību dažādās latviešu profesionālajās organizācijās un pauž gatavību dalīties zināšanās ar citiem. Tikai pēc zināmas profesionālās nostabilizēšanās 
mītnes valstī paveras iespēja veidot biznesa vai sociālās sadarbības projektus ar Latviju. Biznesa gadījumā aktualizējas iespēja atjaunot Latvijā iegūto kultūras kapitālu un veidot biznesa sadarbības projektus. Piemēram, juristi, finansisti, grāmatveži un IT speciālisti ir tās emigrantu grupas, kurām ir iespēja veidot šādus sadarbības biznesus ar Latviju un izmantot Latvijā iegūto pirmsmigrācijas kultūras kapitālu savienojumā ar migrācijas laikā iegūto kultūras kapitālu.

Attiecībā uz Latvijā iegūtā kultūras kapitāla nozīmi adaptācijas sākumposmā (izglītība, darba pieredze, valodu zināšanas, vispārējās un specifiskās profesionālās prasmes) pētījumā veiktās intervijas ḷauj secināt, ka tas ir nozīmīgs emigrantu resurss, bet nav pietiekams, lai veidotu sekmīgu karjeru ārvalstīs (konkrēti, Lielbritānijā, Vācijā, Norvēǵijā, Zviedrijā un ASV). Lielākoties augsti kvalificētajiem Latvijas emigrantiem, kas vēlas veidot profesionālo karjeru, pārejas posmā ir jāpieliek lielas pūles, lai attīstītu savu kultūras kapitālu un pielāgotu to vietējā darba tirgus prasībām. 


\section{TURPMĀKĀS MOBILITĀTES PLĀNI: ATGRIEZTIES LATVIJĀ VAI NE?}

Latvijā politiskajā darba kārtībā joprojām ḷoti aktuāls ir jautājums par Latvijas emigrantu atgriešanos Latvijā (Ministru kabinets, 2019). Globālās talantu konkurences apstākḷos augsti kvalificētu migrantu atgriešanās ir viens no faktoriem, kas var veicināt ekonomikas attīstību un arī tuvināšanos Rietumu demokrātijām (Hooper \& Sumption, 2016). Daudzu izcelsmes valstu politikas ir vērstas uz atgriešanās jeb remigrācijas veicināšanu tieši attiecībā uz augsti kvalificētiem speciālistiem, lai sekmētu "smadzeṇu cirkulāciju” vai "smadzeṇu ieguvumus" iepretim "smadzeṇu aizplūšanas” problēmai (Zweig, 2006; Klagge \& Klein-Hitpaß, 2008; Engbersen \& Jansen, 2013; Tejada et al., 2014; Sahoo \& Pattanaik, 2014; Hooper \& Sumption, 2016). Šīs nodaḷas mērḳis ir analizēt faktorus, kas nosaka augsti kvalificētu Latvijas speciālistu plānus atgriezties Latvijā, un atbildēt uz jautājumiem, kādi speciālisti biežāk apsver iespēju atgriezties Latvijā un kāpēc.

Pasaulē veiktie pētījumi par atgriešanos izcelsmes valstīs piedāvā atškirīigas teorētiskās pieejas. Viena no agrīnajām teorijām attiecībā uz remigrāciju 
ir neoklasiskā ekonomikas pieeja. Saskaṇā ar šo pieeju migrants ir racionāla būtne, kas vēlas paaugstināt savus ienākumus, bet atgriešanās izcelsmes valstī aplūkota kā neveiksmīgs mēǵinājums paaugstināt ienākumus ārvalstīs, jo mērḳis iekḷauties uzṇemošās valsts ekonomiskajā sistēmā un gūt lielākus ienākumus nav sasniegts (Todaro, 1969). Cita teorētiskā pieeja remigrācijas pētniecībā ir darba migrācijas jaunā ekonomika. Šajā teorētiskajā modelī atgriešanās izcelsmes valstī aplūkota kā migrācijas procesa daḷa, un saskaṇā ar šo pieeju atgriešanās daudzos gadījumos ir iepriekš plānota (Stark, 1991). Paralēli ekonomikas teorijām atgriešanās migrāciju un ciešu saišu saglabāšanu ar izcelsmes valsti analizē arī transnacionālisma pieejas pārstāvji, kas veikuši daudzus pētījumus par migrantu integrēěanos uzṇemošajās valstīs un transnacionālisma fenomenu (Pries, 1999; Fitzgerald, 2000; Kivisto, 2001; Levitt \& Glick Schiller, 2004; Vertovec, 2004; Carling \& Hoelscher, 2013; Waldinger, 2017).

Neskatoties uz minēto teoriju plašo pielietojumu, salīdzinoši maz pētījumu ir veikts tieši par augsti kvalificētu migrantu remigrāciju. Arī Latvijas pētniecības laukā trūkst pētījumu, kas aplūkotu augsti kvalificētu migrantu atgriešanās plānus un to īstenošanu. Latvijā veiktie pētījumi par remigrāciju lielākoties attiecas uz plašāku grupu - visiem emigrantiem, bet padziḷināti nav pētīta augsti kvalificēto speciālistu remigrācija (Apsite, 2011b; Hazans, 2016; Krisjane, Apsite-Berina, \& Berzins, 2016; Šūpule \& Kḷave, 2018). Minētajos pētījumos nav aplūkoti arī tādi faktori kā integrācijas mītnes zemē un transnacionālisma saišu ietekme uz remigrācijas plāniem.

Attiecībā uz pētījumiem par remigrāciju pasaulē jānorāda arī uz zināmām grūtībām izmantot tajos iegūtās atziṇas. Liela dạ̣a pētījumu (piemēram, Waldorf, 1995; Güngör \& Tansel, 2008; Makina, 2012; Franses, 2015; Tezcan, 2019) aplūko remigrācijas procesus saistībā ar trešo valstu valstspiederīgo migrāciju uz Eiropu un ASV, bet Eiropas Savien̄ibas gadījumā tā ir pilnīgi cita situācija. Trešo valstu valstspiederīgo migrācijas regulējums būtiski atšķiras no ES valstu un EEZ iekšējās migrācijas regulējuma. Citiem vārdiem, trešo valstu valstspiederīgie saskaras ar pavisam citu migrācijas režīmu nekā Latvijas valstspiederīgie, un viņiem ir ievērojami grūtāk pārcelties turp un atpakaḷ. ES pilsoṇa statuss ir ievērojami labvēlīgāks migrācijas iespēju ziṇā un īpaši ES robežās paredz ievērojami lielāku pārvietošanās brīvību. Augsti kvalificēti speciālisti no Latvijas lielākoties var brīvi izvēlēties - palikt uzn,emošajā valstī vai atgriezties Latvijā, jo migrācijas ierobežojumi un vīzu beigšanās termiṇi viṇus būtiski neietekmē. Tātad atgriešanās Latvijā lielākā mērā ir brīvprātīga izvēle, nevis piespiedu situācija, kad beigusies uzturēšanās 
vīza. Labvēlīgais migrācijas režīms ES sekmē arī to, ka visas mobilitātes izvēles ir daudz vienkāršākas, un tas ietekmē transnacionālu saišu veidošanos ar dažādām vietām, tajā skaitā ar izcelsmes valsti (Engbersen, Snel, \& Boom, 2010; Glorious, 2013).

Lai analizētu integrācijas uzṇemošajā valstī un transnacionālisma saišu ietekmi uz remigrācijas plāniem, šajā nodạ̦ā ir izmantoti Eiropas Sociālā fonda (ESF) projekta "Latvijas emigrantu kopienas: nacionālā identitāte, transnacionālās attiecības un diasporas politika” dati. Analīzē galvenie pētnieciskie jautājumi ir šãdi: (1) Vai transnacionālisma saites ietekmē augsti kvalificētu Latvijas emigrantu ES plānus atgriezties Latvijā? (2) Vai sociālās un ekonomiskās integrācijas pakāpe ietekmē augsti kvalificētu Latvijas emigrantu plānus atgriezties Latvijā? (3) Vai emigrācijas iemesli ietekmē augsti kvalificētu Latvijas emigrantu plānus atgriezties Latvijā? Nodaḷas struktūra ir pakārtota pētnieciskajiem jautājumiem, tādēḷ sākumā padziḷināti raksturotas ievadā minēto teorētisko pieeju un iepriekš veikto empīrisko pētījumu galvenās atziṇas attiecībā uz remigrācijas procesiem un faktoriem, kas nosaka remigrācijas plānus. Balstoties uz teorētiskajām atziṇām, izvirzītas pētnieciskās hipotēzes, kuras turpinājumā testētas, izmantojot kvantitatīvās aptaujas datus. Lai sniegtu korektu priekšstatu par izmantotajiem datiem un datu analīzes metodēm, atsevišķa sadaḷa ir veltīta izmantotās izlases un analīzes stratēǵijas raksturojumam. Analīzes rezultātu izklāsts noslēdzas ar galvenajiem analīzes secinājumiem un diskusiju par pētījuma ierobežojumiem, kuri neḷauj izdarīt vispārinošus secinājumus.

\subsection{TEORĒTISKĀS ATZIṆAS UN HIPOTĒZES}

Divas galvenās ekonomiskās teorijas par atgriešanās migrāciju (neoklasiskā ekonomikas pieeja un NELM) ir testētas daudzos ietekmīgos pētījumos (Stark, 1991; Borjas \& Bratsberg, 1996; Constant \& Massey, 2002; Haas \& Fokkema, 2011). Būtiskākie šo pētījumu secinājumi ir šādi: lai gan daudzi migranti pārvietojas no vienas vietas uz citu, lai paaugstinātu savus ienākumus, migrācijas lēmumi nav balstīti tikai uz individuālu izmaksu un ieguvumu izvērtējumu. Galvenie neoklasiskās ekonomikas skaidrojošā modeḷa trūkumi attiecas uz tā nespēju izskaidrot, kādēḷ migranti saglabā saites ar savu izcelsmes valsti un sūta maksājumus vai veic investīcijas tajā, jo šī pieeja nenovērtē nozīmi, kāda ir piederības sajūtai izcelsmes valstij, kopienai un gímenei, kas palikusi izcelsmes valstī. 
NELM pieejā migrācija tiek aplūkota plašāk: nevis kā indivīda stratēǵija paaugstināt savus ienākumus, bet gan kā mājsaimniecības pieeja ienākumu paaugstināšanā (Stark, 1991). Līdz ar to ienākumu sūtišsana ǵimenei ir loǵiska darbība, tāpat kā atgriešanās izcelsmes valstī, kad plānotais kapitāls ir sakrāts (piemēram, uzṇēmējdarbības sākšanai vai privātmājas būvniecībai). Abas minētās ekonomikas teorijas tiek kritizētas par to, ka tās ignorē būtiskus konteksta faktorus (gan uzṇemošajā, gan nosūtošajā valstī) un neṇem vērā neekonomiskās atgriešanās migrācijas faktorus (Cassarino, 2004). Pētījumu rezultāti attiecībā uz abu minēto teoriju skaidrojošo potenciālu ir pretrunīgi. Ietekmīgajā Emīlijas Konstantes (Amelie Constant) un D. S. Maseja pētījumā (Constant \& Massey, 2002) testētas abas teorijas, un pētījums atklāja, ka abi skaidrojošie model̦i ir piemēroti. Tas nozīmē, ka atgriešanās migrācija ir komplekss fenomens, kuram nevar piemērot vienu skaidrojumu. Vēlāk 2015. gada pētījumā Heins de Hāss (Hein de Haas) kopā ar kolēgiem (Haas, Fokkema, \& Fihri, 2015) pārbaudīja abas teorijas attiecībā uz marokāṇu emigrantiem un izdarīja līdzīgus secinājumus: abas ekonomikas pieejas jāaplūko kā savstarpēji papildinošas. Šajā analīzē neoklasiskās ekonomikas pieeja ḷauj izvirzīt hipotēzi, ka tie emigranti, kas nav apmierināti ar savu ekonomisko situāciju un ienākumiem uzṇemošajā valstī, drīzāk varētu apsvērt atgriešanos Latvijā nekā tie emigranti, kas ir apmierināti ar ienākumiem.

Kā jau ievadā minēts, transnacionālisma paradigma piedāvā citu pieeju, kā aplūkot migrācijas, tajā skaitā emigrācijas, procesus. Transnacionālisma teorija uzsver daudzveid̄̄gās saites starp indivīdiem, grupām un institūcijām, kas saglabājas, indivīdam migrējot no vienas vietas uz citu (Glick Schiller, Basch, \& Blanc-Szanton, 1992; Faist, 1998; Portes, Guarnizo, \& Landolt, 1999). Transnacionālisms kritizē arī metodoloǵisko nacionālismu, tā vietā parādot un raksturojot transnacionālos migrācijas tīklus un transnacionālo sociālo telpu, kas palielina iespēju, ka migrācija turpinās no punkta $A$ uz punktu $B$, tad uz punktu $C$ un tā tālāk $(A \rightarrow B \rightarrow C \rightarrow D)$. Transnacionālisma pieeja aicina aplūkot migrāciju plašāk un saredzēt to, ka atgriešanās migrācija arī nav galīgā izvēle $(A \rightarrow B \rightarrow A)$, jo pēc tās atkal ir iespējama jauna emigrācija (piemēram, $A \rightarrow B \rightarrow A \rightarrow C$ ). N̦emot vērā 21. gadsimtā pieejamās globālās komunikācijas tehnoloǵijas un aviācijas attīstību, arī tā saucamās šurpu turpu migrācijas iespējas ir būtiski uzlabojušās. Daudzas valstis ir kḷuvušas liberālākas pilsonības ziṇā un piel̦auj dubulto pilsonību, vismaz ar daḷu valstu. Kopumā tas palīdz uzturēt daudzveidīgas saites un kontaktus gan profesionāli, gan biznesa vidē, gan arī privātajā sfērā (Pries, 2016).

Transnacionālismam raksturīgās aktivitātes, piemēram, maksājumi radiniekiem uz izcelsmes valsti, sekošana notikumiem izcelsmes valstī, radinieku 
un draugu apciemošana gan izcelsmes, gan uzṇemošajā valstī, palīdz uzturēt ciešas saites ar izcelsmes valsti (Haas \& Fokkema, 2011). Daudzi pētījumi parāda, ka minētās transnacionālisma aktivitātes veicina daudzveid̄̄gas piederības saites un dubulto lojalitāti gan mītnes valstij, gan izcelsmes valstij (Portes, Guarnizo, \& Landolt, 1999), un tas savukārt atvieglo atgriešanos mītnes valstī (Haas \& Fokkema, 2011; Carling \& Erdal, 2014; Yahirun, 2014). E. Konstante un D. S. Masejs (Constant \& Massey, 2002) savā pētījumā secina, ka maksājumu sūtǐšana uz izcelsmes valsti pozitīvi korelē ar atgriešanos: tie, kas sūta naudu ǵimenei, biežāk plāno atgriezties un atgriežas izcelsmes valstī. Ģimenes locekḷi, draugi un nekustamais īpašums izcelsmes valstī ir vēl daži faktori, kas sekmē atgriešanos (Dustmann, 2003; Gibson \& McKenzie, 2009). Ciešas saites un regulāra ciemošanās izcelsmes valstī arī tiek uzskatîti par atgriešanās determinantiem (Jong 2000; Constant \& Massey, 2002). Tomēr pētnieki norāda: pastāv iespēja, ka šie faktori darbojas arī pretēji. Regulāra viesošanās izcelsmes valstī un citi cieši kontakti darbojas kā "realitātes kontrole”, lai izvērtētu savas iespējas atgriežoties, un, ja izcelsmes valstī nav vērojami uzlabojumi (piemēram, karjeras izaugsme, biznesa iespējas, plašāk - arī valsts ekonomiskā izaugsme, korupcijas mazināšana u. tml.), indivīdi var secināt, ka viniiem labāk ir palikt mītnes valstī, nevis atgriezties (Carling \& Pettersen, 2014). Balstoties uz minētajiem argumentiem, šajā analīzē testēšanai izvirzīta hipotēze, ka ciešas saites ar izcelsmes valsti pozitīvi ietekmē augsti kvalificētu speciālistu atgriešanās plānus.

Saskaṇā ar E. Konstantes un D. S. Maseja (Constant \& Massey, 2002) pētījumu par turku migrantiem Vācijā lēmumu palikt šajā valstī lielā mērā nosaka sociālās saites un piederības sajūta Vācijai. Līdzīgi arī H. de Hāss ar kolēǵiem (Haas, Fokkema, \& Fihri, 2015) pētījumā par marokāņiem Eiropā secina, ka sociokulturālā integrācija mītnes valstī negatīvi ietekmē plānus atgriezties izcelsmes valstī. Balstoties uz šiem pētījumiem, pārbaudei izvirzīta hipotēze, ka spēcīga piederības sajūta uzṇemošajai valstij negatīvi ietekmē augsti kvalificētu Latvijas emigrantu atgriešanās plānus.

Spēcīgāka piederības sajūta mītnes valstij parasti attīstās ilgākā laika posmā. Vairāki pētījumi parāda (Constant \& Massey, 2002; Dustmann, 2003) - jo ilgāk indivīds dzīvo konkrētajā mītnes valstī, jo ciešāka piederības sajūta veidojas ar šo valsti un vietu, un ir lielāka varbūtība, ka persona pien̦ems lēmumu palikt mìtnes valstī pavisam.

Latvijas emigrantu gadījumā būtisks faktors piederības sajūtas veidošanā, ko nevar neanalizēt, ir arī emigranta etniskā piederība. Pētījumos citās valstīs atklāts, ka piederība pie mazākumtautības izcelsmes valstī var negatīvi 
ietekmēt atgriešanās plānus vidējā termiṇā (Thorat \& Newman, 2010; Her$\operatorname{cog} \&$ Siddiqui, 2014). Hipotētiski šĩ tendence ir attiecināma arī uz augsti kvalificētiem mazākumtautību emigrantiem no Latvijas, jo, piemēram, Latvijas krieviem ir mazāk izteikta piederības sajūta Latvijai nekā latviešiem (Zepa, Šūpule, \& Krastiṇa, 2011). Jāatzīmē, ka kopumā Latvijas krievu īpatsvars emigrantu vidū ir lielāks salīdzinājumā ar Latvijas krievu īpatsvaru patstāvīgo iedzīvotāju vidū (CSP, 2020b). To daḷēji var skaidrot ar Latvijas krievu negatīvo viedokli par Latvijas valdību, un jo īpaši par Latvijā īstenoto etnopolitiku valodas, izglītības un pilsonības jomā (Zepa et al., 2005). Latvijas krievi biežāk izjūt atsvešinātību un nostājas opozīcijā valdības īstenotajai politikai. Balstoties uz minētajiem argumentiem, pārbaudei izvirzīta hipotēze, ka Latvijas krievi sava mazākumtautības statusa dẹl izjūt vājāku piederību Latvijai un retāk apsver atgriešanos Latvijā nekā latvieši.

Iepriekšējos pētījumos novērota arī likumsakarība, ka tie migranti, kuru partneri ir mītnes zemes pastāvīgie iedzīvotāji, salīdzinoši retāk apsver iespēju atgriezties izcelsmes valstī (Pungas et al., 2012). Pētījumā par valodu konkurenci Latvijas diasporā (Kḷave \& Šūpule, 2017) atklāts, ka, dzīvojot emigrācijā, mītnes valodas lietošana ne tikai publiskajā telpā, bet arī mājās būtiski pieaug. Īpaši raksturīgi tas ir jauktajām ǵimenēm, kurās vienam no partneriem dzimtā valoda ir mītnes valsts valoda. Jāatzīmē, ka jaukto laulību skaits Latvijas emigrantu, īpaši sieviešu, vidū ir l̦oti augsts. Aptaujas izlasē $20 \%$ visu respondentu partneris ir latvietis, $2 \%$ - krievs un 36\% - citas etniskās grupas pārstāvis (42\% aptaujāto nav pastāvīga partnera). Līdz ar to analīzē pārbaudīta hipotēze, vai kopdzīve ar partneri, kas nav latvietis vai krievs, ietekmē plānus atgriezties Latvijā. Sākotnēji izvirzīta hipotēze, ka gadījumā, ja partneris ir citas tautîbas, samazinās varbūtība plānot atgriešanos Latvijā.

Kopumā teorētiskās izpētes un citu pētījumu analīzes rezultātā pārbaudei ir izvirzītas šãdas hipotēzes:

(1) N̦emot vērā neoklasiskās ekonomikas pieeju, var sagaidīt, ka tie emigranti, kas nav apmierināti ar savu darbu un izjūt diskrimināciju, ar lielāku varbūtību apsver iespēju atgriezties Latvijā, un otrādi - tie, kas ir apmierināti ar darba apstākḷiem mītnes valstī, ar mazāku varbūtību apsver iespēju atgriezties Latvijā.

(2) Balstoties uz transnacionālisma pieejas atziṇām, tiek sagaidīts, ka spēcīga piederības sajūta Latvijai ir pozitīvi saistīta ar plāniem atgriezties Latvijā. Piederības sajūta Latvijai šajā analīzē interpretēta kā sociāli kulturālas saites ar Latviju, tās operacionalizētas kā sekošana ziṇām par notikumiem Latvijā, piederības sajūta Latvijas iedzīvotājiem, 
tuvi draugi, kas dzīvo Latvijā, viesošanās Latvijā vismaz vienu reizi pusgadā, naudas pārvedumi radiniekiem Latvijā un privātais īpašums Latvijā. Savukārt attiecībā uz piederības sajūtu mītnes valstij izvirzīta hipotēze, ka ciešas saites ar mītnes valsti mazina varbūtību apsvērt atgriešanos Latvijā. Piederības sajūta jeb ciešas saites ar mītnes valsti šajā analīzē operacionalizētas kā sekošana ziṇām par notikumiem mītnes valstī, piederības sajūta mītnes valstij un mītnes valsts iedzīvotājiem, tuvi draugi, kas dzīvo mītnes valstī. N̦emot vērā to, ka ilgstoša dzīve mītnes valstī sekmē piederības sajūtas veidošanos mītnes valstij, tiek sagaidīts, ka tie emigranti, kas mītnes valstī uzturas ilgāk par pieciem gadiem, ar mazāku varbūtîbu apsver atgriešanos Latvijā.

(3) Attiecībā uz emigrantu etnisko piederību pārbaudīta hipotēze par mazākumtautības statusa ietekmi uz atgriešanās plāniem, un tiek sagaidīts, ka augsti kvalificētie Latvijas krievu emigranti ar mazāku varbūtību plāno atgriezties Latvijā. N, Nemot vērā pētījumus par jauktajām laulībām emigrantu vidū (Kḷave \& Šūpule, 2017), izvirzīta hipotēze, ka emigranti, kuriem partneris nav latvietis vai krievs, ar mazāku varbūtību plāno atgriezties Latvijā.

\subsection{ANALİZES DATU RAKSTUROJUMS UN ANALİZES STRATĒG̣IJA}

\section{IZMANTOTIE DATI}

Datu analīzei izmantoti ESF projekta "Latvijas emigrantu kopienas: nacionālā identitāte, transnacionālās attiecības un diasporas politika” dati, kas iegūti, aptaujājot 14068 Latvijas emigrantus. Lai izpētītu ES dzīvojošu augsti kvalificētu Latvijas emigrantu atgriešanās plānus, izveidota aptaujas apakšizlase, kur iekḷauti tikai tie Latvijas emigranti, kuri ir pirmās paaudzes aizbraucēji un dzīvo kādā ES valstī ārpus Latvijas, kuri aptaujas veikšanas brīdī strādāja uzṇemošajā valstī un kuriem bija maǵistra vai doktora grāds (atbilstoši 91\% un 9\%). Tātad augsti kvalificētā emigranta ES statusu šajā apakšizlasē nosaka tas, ka respondentam ir magistra vai doktora grāds un viņš aptaujas brīdī strādā. Analīzē izmantotās apakšizlases lielums ir 820 respondenti.

Lai gan aptaujas dati kopumā ir uzskatāmi par tādiem, kas reprezentē Latvijas emigrantu kopumu ES, jāatzīmē arī daži aptaujas datu trūkumi, kas ir neizbēgami jebkurā aptaujā. Pirmām kārtām aptaujas datu ieguves metode ir interneta aptauja, kurai raksturīga respondentu pašizlase. 
4.1. tabula. Respondentu raksturojums pēc emigrācijas valsts, dzimuma, vecuma, izglītības, etniskās piederības, laulātības statusa un emigrācijas laika $(N=820)$

\begin{tabular}{|c|c|c|}
\hline Emigrācijas valsts & $\%$ & $N$ \\
\hline Lielbritānija (aptaujas brīdī ES valsts) & 22 & 182 \\
\hline Vācija & 17 & 137 \\
\hline İrija & 4 & 34 \\
\hline Ziemel̦valstis, izṇemot Norvēǵiju & 15 & 124 \\
\hline Dienvideiropas valstis & 6 & 47 \\
\hline Rietumeiropas valstis, izṇemot Lielbritāniju, Vāciju un Īriju & 30 & 249 \\
\hline Austrumeiropas valstis & 6 & 47 \\
\hline \multicolumn{3}{|l|}{ Dzimums } \\
\hline Virietis & 26 & 214 \\
\hline Sieviete & 74 & 606 \\
\hline \multicolumn{3}{|l|}{ Vecums } \\
\hline $15-34$ & 45 & 366 \\
\hline $35-44$ & 31 & 256 \\
\hline $45-54$ & 16 & 133 \\
\hline $55+$ & 8 & 65 \\
\hline \multicolumn{3}{|l|}{ Izglītības joma (iespējamas vairākas atbildes) } \\
\hline Sociālās zinātnes, komerczinības un tiesības & 45 & 368 \\
\hline Humanitārās zinātnes un māksla & 22 & 181 \\
\hline Inženierzinātnes, ražošana un būvniecība & 11 & 94 \\
\hline Pedagoǵija & 7 & 54 \\
\hline Veselības aprūpe un sociālā labklājība & 11 & 90 \\
\hline Dabaszinātnes, matemātika un informācijas tehnoloǵijas & 13 & 105 \\
\hline Cits & 2 & 15 \\
\hline
\end{tabular}

Izglìtības līmenis

\begin{tabular}{rcc}
\hline Maǵistra grāds & 91 & 749 \\
\hline Doktora grāds & 9 & 71 \\
\hline Augsti kvalificētie STEM jomās ar maǵistra vai doktora grādu & 23 & 193 \\
\hline & & \\
\hline Ltniskā piederība & & \\
\hline Latvietis & 84 & 692 \\
\hline Krievs & 11 & 87 \\
\hline Cita & 5 & 41 \\
\hline
\end{tabular}




\begin{tabular}{rrrc}
\hline & Latvietis & 20 & 161 \\
\hline & Krievs & 2 & 20 \\
\hline Etniskā piederība & Cita & 36 & 293 \\
\hline & & 346 \\
\hline & Pirms 2000 & 14 & 110 \\
\hline $2000-2003$ & 9 & 73 \\
\hline $2004-2008$ & 29 & 241 \\
\hline Pēc 2008 & 48 & 396
\end{tabular}

Kā lielākajā daḷā aptauju, arī šajā piedalījās tikai tie respondenti, kuri vēlējās vai kurus sasniedza apjomīgā informēšanas kampaņa par aptaujas veikšanu. Salīdzinājumā ar statistiskajiem novērtējumiem par emigrācijas plūsmām no Latvijas šajā aptaujā ir lielāks augsti kvalificētu sieviešu un latviešu īpatsvars (Hazans, 2015, 2019). 4.1. tabulā ir sniegts vispārīgs aptaujas apakšizlases respondentu raksturojums pēc emigrācijas valsts, dzimuma, vecuma, izglītības, etniskās piederības, laulātības statusa un emigrācijas laika, kas parāda, ka ES valstu pārstāvniecība ir samērā tuvu emigrācijas statistikai, bet sieviešu īpatsvars (76\%) ir pārāk augsts, kā arī latviešu īpatsvars (84\%) ir pārāk augsts.

\section{ANALİZES STRATĒG̣IJA}

Lai pārbaudītu izvirzītās hipotēzes attiecībā uz faktoriem, kas nosaka atgriešanās plānus, izmantota binārās loğistiskās regresijas analīzes metode un SPSS for Windows 22 programmatūra. Atkarīgais main̄̄gais regresijas vienādojumā bija atgriešanās plāni Latvijā tuvāko piecu gadu laikā. Lēmumi par neatkarīgajiem mainīgajiem pien,emti, balstoties gan uz iepriekšējos pētījumos iegūtajām atziṇām, gan uz datu pieejamību veiktajā aptaujā.

\section{Atkarīgā main̄̄gā apraksts}

Lai noskaidrotu Latvijas emigrantu atgriešanās plānus, aptaujā tika iekḷauti trīs jautājumi: (1) Vai jūs domājat, ka atgriezīsieties uz pastāvīgu dzīvi Latvijā tuvāko sešu mēnešu laikā? (2) Vai jūs domājat, ka atgriezīsieties uz pastāvīgu dzīvi Latvijā tuvāko piecu gadu laikā? (3) Vai jūs domājat, ka atgriezīsieties uz pastāvīgu dzīvi Latvijā vecumdienās? 
Saskaṇā ar aptaujas datiem kopumā 3\% augsti kvalificēto Latvijas emigrantu, kas dzīvo ES, plāno atgriezties Latvijā tuvāko sešu mēnešu laikā. 10\% apsver iespēju atgriezties uz pastāvīgu dzīvi Latvijā tuvāko piecu gadu laikā, bet $20 \%$ apsver iespēju atgriezties Latvijā vecumdienās (4.2. tabula). Kopumā 23\% Latvijā atgriezties neplāno, bet $44 \%$ nav izlēmuši un varbūt noteiktos apstākḷos atgrieztos. Turpmākā kvantitatīvo datu analīze vērsta uz tiem respondentiem, kas plāno atgriezties vidējā termiṇā (piecu gadu laikā). Analīzes nolūkos visi aptaujātie ir sadalīti divās grupās: tie, kas plāno atgriezties Latvijā tuvāko piecu gadu laikā (ieskaitot tos, kas plāno atgriezties tuvāko sešu mēnešu laikā), un tie, kas neplāno atgriezties Latvijā tuvāko piecu gadu laikā. Tie aptaujātie, kas nesniedza skaidru atbildi par saviem atgriešanās plāniem, no datu analīzes ir izslēgti.

4.2. tabula. Atgriešanās plāni augsti kvalificētu Latvijas emigrantu vidū* $(N=820)$

\begin{tabular}{rcc}
\hline & $\%$ & $N$ \\
\hline Jā, tuvāko sešu mēnešu laikā & 3 & 21 \\
\hline Jā, tuvāko piecu gadu laikā & 10 & 79 \\
\hline Jā, vecumdienās & 20 & 165 \\
\hline Varbūt, pie noteiktiem apstākljiem/nosacijumiem & 44 & 362 \\
\hline Drīzāk nē & 15 & 123 \\
\hline Noteikti nē & 8 & 70 \\
\hline
\end{tabular}

* Aptaujas datu rezultāti, kombinējot trīs jautājumu atbildes.

\section{Neatkarīgie mainīgie}

Lai analizētu, kuri augsti kvalificētie Latvijas emigranti ar lielāku varbūtību plāno atgriezties Latvijā piecu gadu laikā, visi neatkarīgie mainīgie ir iedalīti vairākās grupās. Pirmā grupa ir kontrolmainīgie, un galvenie sociāldemogrāfiskie rādītāji ir vecums, dzimums, etniskā piederība, partnera etniskā piederība, izglīīība STEM jomās un emigrācijas laiks.

Respondentu vecums aptaujas apakšizlasē ir robežās no 23 līdz 75 gadiem, pavisam jauni cilvēki šajā analīzē nav iekḷuvuši izglītības faktora dēḷ (apakšizlasē iekḷauti tikai tie, kam ir vismaz maǵistra grāds). Dzimums analīzē kodēts tādējādi, ka 0 ir vīrietis, bet 1 ir sieviete. Etniskās piederības raksturošanai iekḷauti divi mainīgie: latvieši un krievi (respondentu nosauktā tautība, kurai viṇi jūtas piederīgi), jo atbilžu variantu “cita tautība” izvēlējies pavisam neliels skaits aptaujāto (5\% jeb 41 respondents). Šie mainīgie kodēti tādējādi, 
ka 0 ir nē, bet 1 ir jā jeb atbilstība pazīmei. Lai noteiktu aptaujāto partnera etniskās piederības ietekmi uz atgriešanās plāniem, arī izmantoti divi mainīgie: partneris ir latvietis vai partneris ir citas tautības pārstāvis, kas nav latviešu vai krievu. Šāds lēmums pieņemts tādēḷ, ka to respondentu skaits, kuri norādīja, ka viṇa partnera tautība ir krievu, ir l̦oti neliels (2\% jeb 20 respondenti), un sākotnējā regresijas analīze neuzrādīja šī mainīgā ietekmi uz atgriešanās plāniem. Salīdzinājumam 26\% aptaujāto (293 respondenti) partneris ir citas tautības (ne latviešu, ne krievu). Arī šie mainīgie kodēti tādējādi, ka 0 ir nē, bet 1 ir jā jeb atbilstība pazīmei. Pētījumā īpaša interese ir par to, kādi migrācijas plāni nākotnē ir augsti kvalificētiem emigrantiem STEM jomās, tādēḷ kā viens no neatkarīgajiem mainīgajiem iekḷauts mainīgais par iegūto izglītību STEM jomās (23\% aptaujas apakšizlasē).

N̦emot vērā to, ka pēdējais lielākais emigrācijas vilnis no Latvijas saistīts ar 2008.-2009. gada ekonomisko krīzi (Hazans, 2019), 2008. gads ir izvēlēts par atskaites gadu, lai raksturotu laiku, kad notikusi emigrācija no Latvijas. Analīzē mainīgais kodēts tādējādi, ka 0 nozīmē - respondents ir emigrējis no Latvijas pirms 2009. gada, bet 1 nozīmē - respondents ir emigrējis pēc 2008. gada. Tie, kas emigrējuši pirms 2009. gada, uzskatāmi par emigrācijā ilgstoši dzīvojošajiem.

Otra neatkarīgo mainīgo grupa, kas izmantota regresijas analīzē, attiecas uz augsti kvalificēto Latvijas emigrantu ES galvenajiem emigrācijas motīviem. Analīzē ir iekḷauti seši aptaujā biežāk atzīmētie emigrācijas motīvi. Visbiežāk minētais motīvs ir iespējas attīstīties (iegūt labu izglītību vai veidot karjeru), to norādījuši 44\% respondentu. 31\% kā emigrācijas galvenos motīvus atzīmējuši vēlmi uzlabot dzīves kvalitāti, 28\% - vēlmi apskatīt pasauli, gūt jaunus iespaidus, draugus, 27\% emigrēt motivējis tas, ka ārzemēs bija iespēja daudz labāk nopelnīt, savukārt 22\% uzsver, ka viṇi gribējuši dzīvot stabilā, sakārtotā valstī, bet $21 \%$ nav patikuši Latvijā notiekošie procesi un politiskā vide. Visi seši mainīgie kodēti tādējādi, ka 0 ir nē, bet 1 ir jā jeb atbilstība pazīmei.

Trešã mainīgo grupa attiecas uz respondentu integrāciju uzṇemošās valsts darba tirgū. Visi apakšizlasē iekḷautie respondenti aptaujas brīdī bija strādājoši, tādēl viṇu integrācijas raksturošanai mītnes valsts darba tirgū izmantots mainīgais, kas mēra respondenta apmierinātību ar savu darbu, un uztvertās diskriminācijas pieredze. Aptaujas anketā apmierinātība ar darbu vērtēta 10 ballu skalā, kur 1 nozīmē - l̦oti neapmierināts ar savu darbu, bet 10 - l̦oti apmierināts ar savu darbu. Analīzei tika izveidots jauns mainīgais, kas iekḷauj atbildes ar vērtējumu no 7 līdz 10 (76\% respondentu). Mainīgais “Apmierinātība ar darbu” 
kodēts ar 0 (nav pazīmes) un 1 (ir pazīme). Uztvertā diskriminācija aptaujas anketā mērīta ar sešiem indikatoriem: (1) jums biežāk nekā vietējiem uzdod neizdevīgus un/vai nepatīkamus darbus; (2) jums ir grūtāk nekā vietējiem vienoties par piemērotu darba grafiku; (3) jums izvirza striktākas darba disciplīnas un/vai darba produktivitātes prasības nekā vietējiem; (4) jums vienmēr jāiet atvaḷinājumā "sliktajā” gadalaikā; (5) par līdzīgu darbu jūs saṇemat mazāku atalgojumu nekā vietējie iedzīvotāji; (6) cita veida netaisnīga attieksme no darba devēja puses. Analīzes nolūkos tika izveidots summārais uztvertās diskriminācijas mainīgais, kas parāda, vai respondents ir izjutis netaisnīgu attieksmi kādā no aptaujā iekḷautajām diskriminācijas situācijām. Izveidotais mainīgais kodēts ar 0 (nav pazīmes) un 1 (ir pazīme). Saskaņā ar aptaujas rezultātiem kopumā 19\% augsti kvalificēto Latvijas emigrantu ir saskārušies ar uztverto diskrimināciju jeb netaisnīgu attieksmi salīdzinājumā ar darba kolēğiem.

Ceturtā un piektā mainīgo grupa attiecas uz piederības sajūtu mītnes zemei un Latvijai. Aptaujas anketā kopumā bija daudz jautājumu, kas raksturo piederības sajūtu. Dažādi mainīgie tika testēti faktoru analīzē, un izvēlētie mainīgie ir tie, kas uzrādīja augstāko savstarpējo korelāciju piederības faktora veidošanā. Piederības sajūtu mītnes zemei raksturo četri mainīgie: (1) regulāri seko līdzi notiekošajam mītnes zemē (1_jāa, regulāri); (2) jūtas l̦oti vai zināmā mērā piederīgs mītnes zemes iedzīvotājiem (1_jā); (3) jūtas cieši vai ḷoti cieši saistīts ar valsti, kurā šobrīd dzīvo (1_jā); (4) ir tuvi draugi starp “vietējiem” mītnes zemē (1_jā). Septini mainīgie, kas raksturo piederības sajūtu Latvijai, arī tika izvēlēti, pamatojoties uz iepriekš veiktās faktoru analīzes rezultātiem: (1) regulāri seko līdzi notiekošajam Latvijā (1_jā, regulāri); (2) jūtas ḷoti vai zināmā mērā piederīgs Latvijas iedzīvotājiem (1_jā); (3) jūtas cieši vai ḷoti cieši saistīts ar Latviju (1_jā); (4) ir tuvi draugi, kas dzīvo Latvijā (1_jā); (5) pieder dzīvoklis vai māja Latvijā (1_jā); (6) regulāri atbalsta kādu no saviem radiniekiem vai draugiem Latvijā finansiāli (vismaz četras reizes gadā) (1_jā); (7) brauc uz Latviju vismaz reizi pusgadā (1_jā). Aptaujas rezultāti atklāj, ka no augsti kvalificētajiem Latvijas emigrantiem ES 74\% regulāri seko līdzi notiekošajam Latvijā un 68\% regulāri seko līdzi notiekošajam mītnes zemē. 74\% jūtas cieši vai l̦oti cieši saistīti ar Latviju, bet 57\% - ar mītnes valsti. 65\% respondentu jūtas piederīgi Latvijas iedzīvotājiem, bet $48 \%$ - mītnes valsts iedzīvotājiem. 91\% aptaujāto ir tuvi draugi Latvijā, bet 66\% - starp "vietējiem” mītnes zemē. 50\% augsti kvalificēto Latvijas emigrantu brauc uz Latviju vismaz reizi pusgadā. Ievērojami mazāks skaits (24\%) regulāri atbalsta kādu no saviem radiniekiem vai draugiem Latvijā finansiāli (vismaz četras reizes gadā), bet 55\% pieder dzīvoklis vai māja Latvijā. 
Kopumā visi neatkarīgie main̄̄gie, izṇemot vecumu, ir pārveidoti par binārajiem mainīgajiem, kur 1 nozīmē, ka noteikta pazīme ir piemītoša, bet atbildes "nē” vai "grūti pateikt" ir apkopotas un kodētas kā 0 .

\subsection{ANALİZES REZULTĀTII}

Binārās loğistiskās regresijas analīzes modelis ar galvenajiem faktoriem, kas ietekmē atgriešanās plānus, ir sā̄sināti apkopots 4.3. tabulā. Regresijas modeḷa raksturošanai izmantotā rādītāja Neigelkerkes $R_{\mathrm{N}}^{2}$ (angl. - Nagelkerke's $R^{2}$ ) vērtība ir 0,371, kas nozīmē, ka konkrētais regresijas analīzes modelis izskaidro $37,1 \%$. Statistika, kas raksturo atkarīgo mainīgo un neatkarīgos mainīgos, ir apkopota 4.4. tabulā.

4.3. tabula. Binārās loǵistiskās regresijas analīzes modelis ar galvenajiem faktoriem, kas ietekmē atgriešanās plānus

\begin{tabular}{|c|c|c|c|c|c|}
\hline & \multirow[t]{2}{*}{ B } & \multirow[t]{2}{*}{ Sig. } & \multirow[t]{2}{*}{$\operatorname{Exp}(B)$} & \multicolumn{2}{|c|}{$\begin{array}{l}\text { 95\% C.I. attiecībā uz } \\
\operatorname{EXP(B)}\end{array}$} \\
\hline & & & & Augšējā & Apakšējā \\
\hline \multicolumn{6}{|l|}{ Pamata raksturojums } \\
\hline Vecums & 0,009 & 0,567 & 1,009 & 0,979 & 1,039 \\
\hline Dzimums (1_sievietes) & 0,070 & 0,824 & 1,072 & 0,580 & 1,982 \\
\hline Augsti kvalificētie STEM jomās & 0,741 & 0,016 & 2,099 & 1,149 & 3,835 \\
\hline Latvieši & 0,466 & 0,542 & 1,593 & 0,357 & 7,106 \\
\hline Krievi & $-0,881$ & 0,304 & 0,414 & 0,077 & 2,226 \\
\hline Partneris latvietis & $-0,455$ & 0,161 & 0,634 & 0,335 & 1,200 \\
\hline Partneris krievs & $-1,645$ & 0,000 & 0,193 & 0,096 & 0,387 \\
\hline Emigrējis pēc 2008. gada & 0,584 & 0,039 & 1,793 & 1,028 & 3,126 \\
\hline \multicolumn{6}{|l|}{ Emigrācijas motivācija } \\
\hline Ārzemēs bija iespēja daudz labāk nopelnīt (1_jā) & $-0,348$ & 0,292 & 0,706 & 0,370 & 1,348 \\
\hline Vēlme uzlabot savas dzīves kvalitāti (1_jā) & $-0,233$ & 0,506 & 0,792 & 0,398 & 1,575 \\
\hline Gribēju dzīvot stabilā, sakārtotā valstī (1_jā) & $-0,616$ & 0,216 & 0,540 & 0,204 & 1,433 \\
\hline Nepatika Latvijā notiekošie procesi, politiskā vide (1_jā) & $-1,743$ & 0,008 & 0,175 & 0,049 & 0,631 \\
\hline $\begin{array}{l}\text { lespējas attīstīties (iegūt labu izglītību vai veidot karjeru) } \\
\text { (1_jā) }\end{array}$ & $-0,430$ & 0,147 & 0,650 & 0,363 & 1,163 \\
\hline
\end{tabular}


Vēlme apskatīt pasauli, gūt jaunus iespaidus, draugus

0,820

0,006

2,270

1,259

4,095

(1_jā)

Piederības sajūta mïtnes valstij

\begin{tabular}{|c|c|c|c|c|c|}
\hline $\begin{array}{l}\text { Regulāri seko līdzi notiekošajam mītnes zemē (1_jā, } \\
\text { regulāri) }\end{array}$ & 0,060 & 0,834 & 1,062 & 0,607 & 1,856 \\
\hline $\begin{array}{l}\text { Jūtas l̦oti vai zināmā mērā piederīgs mītnes zemes } \\
\text { iedzīvotājiem (1_jā) }\end{array}$ & $-0,289$ & 0,340 & 0,749 & 0,414 & 1,356 \\
\hline $\begin{array}{l}\text { Jūtas cieši vai ḷoti cieši saistīts ar valsti, kurā šobrīd dzīvo } \\
\text { (1_jāa) }\end{array}$ & $-1,359$ & 0,000 & 0,257 & 0,142 & 0,464 \\
\hline Ir tuvi draugi starp "vietējiem" mītnes zemē (1_jā) & $-0,267$ & 0,337 & 0,766 & 0,445 & 1,320 \\
\hline \multicolumn{6}{|l|}{ Piederības sajūta Latvijai } \\
\hline Regulāri seko līdzi notiekošajam Latvijā (1_jā, regulāri) & 0,648 & 0,091 & 1,911 & 0,901 & 4,056 \\
\hline $\begin{array}{l}\text { Jūtas ḷoti vai zināmā mērā piederīgs Latvijas iedzīvotājiem } \\
\text { (1_jā) }\end{array}$ & 0,591 & 0,090 & 1,805 & 0,912 & 3,573 \\
\hline Jūtas cieši vai l’oti cieši saistīts ar Latviju (1_jā) & 0,914 & 0,069 & 2,495 & 0,930 & 6,694 \\
\hline Ir tuvi draugi, kas dzīvo Latvijā (1_jā) & 1,063 & 0,107 & 2,895 & 0,793 & 10,562 \\
\hline Pieder dzīvoklis vai māja Latvijā (1_jā) & 0,192 & 0,492 & 1,212 & 0,701 & 2,096 \\
\hline $\begin{array}{l}\text { Regulāri atbalsta kādu no saviem radiniekiem vai } \\
\text { draugiem Latvijā finansiāli (vismaz četras reizes gadā) } \\
\text { (1_jā) }\end{array}$ & $-0,250$ & 0,431 & 0,779 & 0,419 & 1,450 \\
\hline Brauc uz Latviju vismaz reizi pusgadā (1_jā) & 0,491 & 0,078 & 1,634 & 0,946 & 2,824 \\
\hline \multicolumn{6}{|l|}{ Integrācija darba tirgū } \\
\hline Ir pieredzējis diskriminējošu attieksmi darbā (1_jā) & $-0,177$ & 0,596 & 0,838 & 0,436 & 1,610 \\
\hline$\underline{\text { Ir apmierināts ar darbu (1_jā) }}$ & 0,084 & 0,772 & 1,088 & 0,615 & 1,925 \\
\hline Konstante & $-4,712$ & 0,000 & 0,009 & & \\
\hline Neigelkerkes $R_{\mathrm{N}}^{2}$ & 0,371 & & & & \\
\hline
\end{tabular}

4.4. tabula. Statistika, kas raksturo atkarīgo mainīgo un neatkarīgos mainīgos $(N=820)$

\begin{tabular}{llc}
\hline & $\%$ & $N$ \\
\hline Plāno atgriezties Latvijā tuvāko piecu gadu laikā (1_jā) & 12 & 100 \\
\hline Pamata raksturojums & & \\
\hline Dzimums (1_sievietes) & 74 & 606 \\
\hline Augsti kvalificētie STEM jomās & 23 & 193 \\
\hline Latvieši & 84 & 692 \\
\hline Krievi & 11 & 87 \\
\hline Partneris latvietis & 20 & 161 \\
\hline
\end{tabular}




\begin{tabular}{|c|c|c|}
\hline Partneris krievs & 36 & 293 \\
\hline Emigrējis pēc 2008. gada & 48 & 396 \\
\hline \multicolumn{3}{|l|}{ Emigrācijas motivācija } \\
\hline Ārzemēs bija iespēja daudz labāk nopelnīt (1_jā) & 27 & 218 \\
\hline Vēlme uzlabot savas dzīves kvalitāti (1_jā) & 31 & 257 \\
\hline Gribēju dzīvot stabilā, sakārtotā valstī (1_jā) & 22 & 178 \\
\hline Nepatika Latvijā notiekošie procesi, politiskā vide (1_jā) & 21 & 170 \\
\hline lespējas attīstīties (iegūt labu izglīiību vai veidot karjeru) (1_jā) & 44 & 360 \\
\hline Vēlme apskatīt pasauli, gūt jaunus iespaidus, draugus (1_jā) & 28 & 232 \\
\hline \multicolumn{3}{|l|}{ Piederības sajūta mītnes valstij } \\
\hline Regulāri seko līdzi notiekošajam mītnes zemē (1_jā, regulāri) & 68 & 554 \\
\hline Jūtas l̦oti vai zināmā mērā piederīgs mītnes zemes iedzīvotājiem (1_jā) & 48 & 395 \\
\hline Jūtas cieši vai l̦oti cieši saistīts ar valsti, kurā šobrīd dzīvo (1_jā) & 57 & 466 \\
\hline Ir tuvi draugi starp "vietējiem" mītnes zemē (1_jā) & 65 & 534 \\
\hline \multicolumn{3}{|l|}{ Piederības sajūta Latvijai } \\
\hline Regulāri seko līdzi notiekošajam Latvijā (1_jā, regulāri) & 74 & 605 \\
\hline Jūtas ḷoti vai zināmā mērā piederīgs Latvijas iedzīvotājiem (1_jā) & 65 & 529 \\
\hline Jūtas cieši vai l̦oti cieši saistīts ar Latviju (1_jā) & 74 & 609 \\
\hline Ir tuvi draugi, kas dzīvo Latvijā (1_jā) & 91 & 746 \\
\hline Pieder dzīvoklis vai māja Latvijā (1_jā) & 55 & 451 \\
\hline $\begin{array}{l}\text { Regulāri atbalsta kādu no saviem radiniekiem vai draugiem Latvijā finansiāli } \\
\text { (vismaz četras reizes gadā) (1_jā) }\end{array}$ & 24 & 201 \\
\hline Brauc uz Latviju vismaz reizi pusgadā (1_jā) & 50 & 411 \\
\hline \multicolumn{3}{|l|}{ Integrācija darba tirgū } \\
\hline Ir pieredzējis diskriminējošu attieksmi darbā (1_jā) & 19 & 159 \\
\hline Ir apmierināts ar darbu (1_jā) & 76 & 626 \\
\hline
\end{tabular}

\section{ATGRIEŠANĀS PLĀNI, EMIGRĀCIJAS MOTIVĀCIJA UN} SOCIĀLDEMOGRĀFISKIE RĀDITTĀJI

Binārās loǵistiskās regresijas modelis par faktoriem, kas ietekmē augsti kvalificētu Latvijas emigrantu ES atgriešanās plānus, atklāj, ka tos neietekmē respondentu vecums un dzimums. Pretēji sagaidītajam, atgriešanās plānus būtiski neietekmē arī respondentu tautība. Tajā pašā laikā regresijas analīze atklāj viennozīmīgi negatīvu korelāciju starp jauktām partnerattiecībām un plāniem atgriezties Latvijā. Tātad - ja emigranta vīrs vai sieva / partneris 
nav latviešu vai krievu tautības, atgriešanās Latvijā visdrīzāk nav plānota. Kontrolējot visus citus faktorus, augsti izglītotie emigranti STEM jomās ar lielāku varbūtību apsver iespēju atgriezties Latvijā. Varbūtība, ka tiek apsvērta atgriešanās Latvijā, ir augstāka arī to emigrantu vidū, kas Latviju atstājuši pēc 2008. gada. Emigrantus, kas aizbraukuši pēc 2008. gada, ir ietekmējušas divas tendences - pirmkārt, migrācijas vilnis, kas saistīts ar 2008.-2009. gada ekonomisko krīzi; otrkārt, pēckrīzes periodam raksturīgā situācija, kad emigrācija tiek uztverta kā “jaunais normālais” (Hazans, 2019). Šos migrantus raksturo arī tas, ka viṇi emigrācijā ir salīdzinoši neilgu laiku, tādēḷ vēl nav izveidojušās tik ciešas saites ar mītnes valsti.

Analizējot, vai migrācijas motīvi ietekmē atgriešanās plānus, konstatēts, ka tiem ir būtiska ietekme. Tas iezīmē atšķirīgas tendences salīdzinājumā ar H. de Hāsa un Tinekes Fokemas (Tineke Fokkema) (Haas \& Fokkema, 2011) veiktā pētījuma rezultātiem. Kontrolējot citu mainīgo ietekmi, analīze atklāj, ka tie respondenti, kas ir emigrējuši, lai apskatītu pasauli, gūtu jaunus iespaidus un draugus, ar lielāku varbūtību apsver iespēju tuvāko piecu gadu laikā atgriezties. Savukārt tie Latvijas emigranti, kas emigrējuši, jo viņiem nepatika Latvijā notiekošie procesi un politiskā vide, ar mazāku varbūtību apsver iespēju tuvāko piecu gadu laikā atgriezties. Citiem visbiežāk minētajiem emigrācijas motīviem nav ietekmes uz Latvijas emigrantu atgriešanās plāniem.

\section{ATGRIEŠANĀS PLĀNI UN INTEGRĀCIJA MĪTNES VALSTS DARBA TIRGŪ}

Pretēji sagaidītajam, mainīgie, kas izmantoti, lai raksturotu migrantu integrāciju mītnes valsts darba tirgū, neietekmē Latvijas emigrantu atgriešanās plānus. Kontrolējot visus citus faktorus, neapmierinātie ar darbu, kā arī tie, kas ir izjutuši netaisnīgu attieksmi darbā vai diskrimināciju, nepauž vēlmi atgriezties Latvijā ar lielāku varbūtību kā citi. Binārās loǵistiskās regresijas analīzē abi minētie mainīgie nozīmīgi neietekmē plānus atgriezties tuvākajos piecos gados. Šajā gadījumā, iespējams, ir jāṇem vērā arī apakšizlases ierobežojumi, jo tajā iekḷauti tikai strādājoši augsti izglītoti emigranti. N̦emot vērā iepriekš minēto, secinājumi par neoklasiskās ekonomikas hipotēzi būtu jāizdara piesardzīgi, un tos nepieciešams pārbaudīt citā pētījumā, kur analīzes datu masīvā iekḷauti arī tie augsti kvalificētie Latvijas emigranti, kas aptaujas brīdī kādu iemeslu dēḷ nestrādā. Iespējams, viens no skaidrojumiem saistīts arī ar to, ka augsti kvalificēti Latvijas emigranti ir salīdzinoši labi integrēti ES uzṇemošo valstu darba tirgos. 
ATGRIEŠANĀS PLĀNI UN PIEDERĪBAS SAJŪTA MĪTNES ZEMEI UN LATVIJAI

Vairākos pētījumos atklāts, ka piederības sajūta mītnes zemei un izcelsmes valstij ir nozīmīgi faktori attiecībā uz emigrantu plāniem atgriezties izcelsmes valstī (Jong, 2000; Constant \& Massey, 2002; Dustmann, 2003; Gibson \& McKenzie, 2009). Binārās loǵistiskās regresijas analīze apstiprina izvirzīto hipotēzi, ka tie, kam ir ciešas saites ar izcelsmes valsti, ar lielāku varbūtību apsver atgriešanos tuvāko piecu gadu laikā. Savukārt tie, kam ir ciešas saites ar mītnes valsti, ar mazāku varbūtību apsver atgriešanos Latvijā. Konkrētāk aplūkojot katra mainīgā ietekmi, var redzēt, ka tie, kuri brauc uz Latviju vismaz reizi pusgadā, jūtas cieši vai ḷoti cieši saistīti ar Latviju, un tie, kuriem ir trīs vai vairāk tuvi draugi Latvijā un kuri jūtas piederīgi Latvijas iedzīvotājiem, ar lielāku varbūtību apsver atgriešanos Latvijā. Savukārt tie, kas jūtas cieši vai l̦oti cieši saistīti ar mītnes valsti, ar mazāku varbūtību apsver atgriešanos Latvijā. Pretēji gaidītajam, tas, ka respondents regulāri finansiāli atbalsta kādu no saviem radiniekiem vai draugiem Latvijā (vismaz četras reizes gadā), būtiski neietekmē atgriešanās plānus. To daḷēji varētu skaidrot ar to, ka strādāšana ārvalstīs ḷauj labāk sniegt nepieciešamo palīdzību tuviniekiem Latvijā, nekā tas būtu, atgriežoties Latvijā.

SECINĀJUMI

Binārās loǵistiskās regresijas analīze par faktoriem, kas ietekmē plānus atgriezties Latvijā, l̦auj izdarīt vairākus būtiskus secinājumus. Attiecībā uz dažādām transnacionālajām aktivitātēm analīze atklāj, ka ciemošanās Latvijā vismaz reizi pusgadā, tuvi draugi Latvijā un sekošana notikumiem Latvijā pozitīvi ietekmē atgriešanās plānus. Vienlaikus ekonomiskas transnacionālās aktivitātes, šajā gadījumā regulāra naudas sūtišana saviem radiniekiem vai draugiem Latvijā un māja vai dzīvoklis īpašumā Latvijā, būtiski neietekmē vidēja termiṇa atgriešanās plānus. Viens no skaidrojumiem šim atklājumam varētu būt saistīts ar to, ka šajos gadījumos atgriešanās, iespējams, ir plānota vēlāk vai vecumdienās. Cits skaidrojums, kas neizslēdz iepriekšējo, ir saistīts ar nepieciešamību gūt salīdzinoši lielus ienākumus, lai varētu uzturēt savus īpašumus un finansiāli atbalstît tuviniekus Latvijā, un, l̦oti iespējams, labākas peḷnas iespējas ir, uzturoties ārzemēs. Šie skaidrojumi sasaistās ar NELM pieejas skaidrojošo modeli, bet, lai to apstiprinātu, nepieciešami citi pētījumi, un konkrētais regresijas modelis to neskaidro. 
Ciešas saites ar Latviju būtiski paaugstina varbūtību, ka augsti kvalificētie Latvijas emigranti plānos atgriezties Latvijā. Visspēcīgākā pozitīvā ietekme uz atgriešanās plāniem tuvāko piecu gadu laikā ir mainīgajam "Jūtas cieši vai l̦oti cieši saistīts ar Latviju”. Tas sakrīt ar secinājumiem vairākos citos pētījumos (Jong, 2000; Constant \& Massey, 2002; Dustmann, 2003; Gibson \& McKenzie, 2009).

Vienlaikus sociāli kulturālajai integrācijai uzṇemošajā valstī drīzāk ir negatīva ietekme uz plāniem atgriezties Latvijā. Tādiem mainīgajiem kā “Jūtos cieši vai l̦oti cieši saistīts ar valsti, kurā šobrīd dzīvoju” un partneris, kas nav ne latvietis, ne krievs, ir būtiska negatīva ietekme uz plāniem atgriezties. Pētījums arī atklāj, ka tie, kas aizbraukuši no Latvijas pirms 2009. gada, tātad salīdzinoši ilgāku laiku dzīvo ārpus Latvijas, retāk apsver atgriešanās iespējas. Šāda tendence ir identificēta arī citos pētījumos (Constant \& Massey, 2002; Dustmann, 2003; Hercog \& Siddiqui, 2014) un tiek skaidrota ar ilgāk pavadīto laiku uzṇemošajā valstī, kas sekmē ciešāku integrāciju tajā.

Pētījuma rezultāti par migrācijas motīvu ietekmi uz atgriešanās plāniem liecina, ka tikai neekonomiskie motīvi būtiski ietekmē plānošanu vai neplānošanu atgriezties. Tie Latvijas emigranti, kas ir emigrējuši, lai apskatītu pasauli, gūtu jaunus iespaidus un draugus, ar lielāku varbūtību apsver iespēju tuvāko piecu gadu laikā atgriezties. Savukārt tie Latvijas emigranti, kas emigrējuši, jo viṇiem nepatika Latvijā notiekošie procesi un politiskā vide, tieši pretēji ar mazāku varbūtību apsver iespēju tuvāko piecu gadu laikā atgriezties.

Pretēji gaidītajam augsti kvalificēto Latvijas emigrantu tautībai nav būtiskas ietekmes uz plāniem atgriezties; to, iespējams, var skaidrot ar aptaujas metodi - interneta aptauju, kurai raksturīga respondentu pašizlase.

Nozīmīgs secinājums attiecas uz augsti kvalificētiem emigrantiem STEM jomās. Analīzes rezultāti liecina, ka šie emigranti ar lielāku varbūtību apsver iespēju atgriezties Latvijā tuvāko piecu gadu laikā. Iespējams, šì augsti kvalificēto emigrantu grupa saskata Latvijā labākas iespējas gan atrast darbu ar labu samaksu, gan justies novērtētiem, jo STEM jomas publiskajā diskursā ir definētas kā prioritāras (Izglītības un zinātnes ministrija, 2017).

Aplūkojot neoklasiskās ekonomikas modeḷa skaidrojošo potenciālu, jāsecina, ka šì binārās loǵistiskās regresijas analīze nesniedz tam apstiprinājumu. Hipotēze, kas izvirzīta, balstoties uz neoklasiskās ekonomikas pieeju, proti, ka tie Latvijas emigranti, kas saskaras ar ekonomiskām grūtībām (nav apmierināti ar darbu un ir saskārušies ar netaisnīgu attieksmi darbavietā), ar lielāku varbūtību apsvērs atgriešanos Latvijā, šajā gadījumā neapstiprinājās. Iespējams, šis modelis nav piemērojams, lai skaidrotu augsti kvalificētu migrantu 
atgriešanās plānus. Analīze parāda, ka atgriešanās plānos lielāka ietekmes varbūtība ir tiem faktoriem, kas nav saistīti ar ekonomiskiem apsvērumiem. Tas l̦auj secināt, ka augsti kvalificētu Latvijas emigrantu atgriešanās Latvijā ir neekonomisks fenomens.

Jāuzsver arī, ka šì analīze ir vērsta nevis uz augsti kvalificēto emigrantu faktisko atgriešanos Latvijā, bet gan uz viṇu plāniem atgriezties. Šādai pieejai ir zināmi ierobežojumi, jo atgriešanās plāni nenozīmē atgriešanos, bet gan tikai atgriešanās iespējamību. Reizē faktiskā atgriešanās ne vienmēr ir saistīta ar plānotu darbību un vēlmi atgriezties, jo dzīvē mēdz notikt dažādas neparedzētas lietas, kas izmaina plānus (Bree, Davids, \& Haas, 2010). Tātad atgriešanās plāni jāuzskata nevis par faktisko atgriešanās prognozi, bet gan par atgriešanās priekšnosacījumiem, un tie raksturo migrantu attieksmi pret savu migrācijas pieredzi (Carling \& Pettersen, 2014).

Izvērtējot dažādus veiktās analīzes ierobežojumus, jāmin vēl vairāki aspekti. Pirmkārt, ierobežojumi, kas attiecas uz aptaujas izlasi, otrkārt, ierobežojumi, kas attiecas uz aptaujā iekḷautajiem jautājumiem, un treškārt, ierobežojumi, kas attiecas uz šādām aptaujām raksturīgo metodologiisko nacionālismu. Analīze balstās uz Latvijā lielākās emigrantu aptaujas datiem, kas ir ḷoti nozīmīgi, jo l̦auj veidot specifiskas apakšizlases noteiktām grupām, šajā gadījumā - augsti izglītotiem un strādājošiem Latvijas pirmās paaudzes emigrantiem ES valstīs. Vienlaikus konkrētajā aptaujā izmantotā metode ietver noteiktus ierobežojumus, jo tā ir pašizlases aptaujas metode. Jāatzīmē gan, ka pašizlases elements piemīt jebkurai aptaujai, kur potenciālais respondents var atteikties piedalīties pētījumā, bet šajā gadījumā potenciālajam respondentam faktiski ir jābūt ieinteresētam Latvijas emigrantu un diasporas jautājumos, lai viņš vispār sāktu aizpildīt aptaujas anketu. Konkrētajā aptaujā pašizlase ir sekmējusi to, ka aptaujā vairāk ir piedalījušās augsti kvalificētas sievietes un latvieši. Hipotētiski arī tie krievu un citu tautību Latvijas emigranti, kas piedalījušies aptaujā, visticamāk, izjūt ciešāku piederību un saites ar Latviju, ja reiz aptaujas uzaicinājums tos ir sasniedzis (skatīt aptaujas dalībnieku rekrutācijas aprakstu) un viṇi ir izlēmuši tajā piedalīties. Otrkārt, pieejamie aptaujas dati ierobežo iespēju aplūkot migrācijas trajektorijas ilgākā laika posmā un skatīt dažādus migrācijas modeḷus (cirkulārā migrācija, atgriešanās pēc pensijas u. tml.), kā arī piederības sajūtu vairākām mītnes valstīm. Šo trūkumu mazliet novērš emigrantu aptaujas otrā viḷna dati, kuru padziḷināta analīze ḷaus izsekot konkrētā longitudinālā pētījuma paneḷa emigrantu migrācijas trajektorijām. Attiecībā uz atgriešanās plāniem redzams, ka to augsti kvalificēto emigrantu skaits, kas tuvāko piecu 
gadu laikā plāno atgriezties Latvijā, 2019. gada aptaujā ir līdzīgs 2014. gada aptaujas rezultātiem (2014. gadā 12\%, 2019. gadā 11\%). Tomēr, arī ņemot vērā šos papildinājumus, jāatzīst, ka migrācijas trajektorijas ir tik komplekss fenomens, ka to var izanalizēt tikai ilgstošos un atkārtotos (longitudinālos) pētījumos vairāku gadu desmitu laikā. 


\section{DISKRIMINĀCIJAS UZTVERE AUGSTI KVALIFICĒTU LATVIJAS SIEVIEŠU VIDŪ EMIGRĀCIJĀ}

Augsti kvalificētu sieviešu migrācija ir aizvien pieaugošs fenomens daudzās pasaules valstīs. Piemēram, laika posmā no 2000. līdz 2011. gadam augsti izglītoto migranšu skaits OECD valstīs ir pieaudzis par 80\% (IOM/OECD, 2014). Kopumā ir būtiski palielinājies arī pētījumu skaits un zināšanas par augsti kvalificētu sieviešu migrāciju (Triandafyllidou \& Isaakyan, 2016), tomēr līdz šim pētījumi lielākoties neskāra Austrumeiropas vai Baltijas valstu augsti kvalificēto sieviešu migrāciju. Augsti kvalificēto sieviešu migrācijas pētījumi citās valstīs rāda, ka, neskatoties uz priekšrocībām, ko sniedz izglītība un profesionālā kvalifikācija, augsti kvalificētas migrantes saskaras ar diskrimināciju un grūtībām adaptēties uzṇemošajās valstīs (Bailey \& Mulder, 2017). Ne tikai mazkvalificētas, bet arī augsti kvalificētas migrantes ir pakḷautas dažādām sociālās stratifikācijas un diskriminācijas sistēmām gan savā izcelsmes valstī, gan arī uzṇemošajā valstī - tas izpaužas kā noteiktas dzimumu vai škiiru privilēgijas vai diskriminācija. Uzṇemošajās valstīs kopumā lielāks pieprasījums darba tirgū ir pēc augsti kvalificētiem indivīdiem, kas ir mobili 
un elastīgi, gatavi pielāgoties visām prasībām, tādēl lielākoties priekšroka tiek dota jauniem neprecētiem vīriešiem (Xiang, 2007; Kirk, Bal, \& Janssen, 2017). Dzimuma diskriminācija kombinācijā ar etnisko diskrimināciju kavē migrantu integrāciju uzṇemošajā valstī, un tas kopumā ir vērtējams negatīvi. Lai gan dzimuma perspektīva migrācijas pētījumos netiek ignorēta, dzimuma dimensija diskriminācijas izpētē migrantu vidū pagaidām nav īpaši analizēta, īpaši attiecībā uz Latvijas emigrantiem. Tādēḷ šajā nodaḷā aplūkota augsti kvalificēto Latvijas emigranšu pieredze attiecībā uz netaisnīgu vai diskriminējošu izturēšanos mītnes valsts darbavietā.

Galvenā uzmanība pievērsta tādam fenomenam kā uztvertā diskriminācija, kas citos pētījumos lielākoties aplūkota no uzṇemošās valsts perspektīvas (Portes, Parker, \& Cobas, 1980; Aguirre, Saenz, \& Hwang, 1989; Brüss, 2008; Estrada, Tsai, \& Chandler, 2008; Vancluysen \& Van Craen, 2010). Nosūtošās valsts perspektīva līdz šim pētījumos par uztverto diskrimināciju skarta reti. Viens no nedaudziem pētījumiem, kas pievērsies Latvijas migrantu diskriminācijai, ir Aivara Tabūna (Tabun, 2019) pētījums. Saskaṇā ar to 35\% Latvijas emigrantu ir saskārušies ar netaisnīgu attieksmi vai diskrimināciju darbavietā. Visbiežāk netaisnīga attieksme norādīta saistībā ar atalgojumu. 18\% Latvijas emigrantu atzīst, ka par līdzīgu darbu ir saṇēmuši mazāku atalgojumu nekā vietējie iedzīvotāji. Šis pētījums arī atklāj, ka mazkvalificētie un vidēji kvalificētie emigranti biežāk nekā vadītāji un augsti kvalificēti speciālisti saskaras ar diskrimināciju darbā. A. Tabūna pētījuma rezultāti atkārtoti apstiprina jau citos pētījumos identificēto, ka Latvijas emigranti darba devēju attieksmi pret darbiniekiem ārvalstīs vērtē pozitīvāk salīdzinājumā ar Latvijas darba devējiem - saskarē ar tiem viṇi netaisnīgu attieksmi sastop biežāk un ir mazāk apmierināti (Mieriṇa, 2016). Tomēr jānorāda, ka minētajos pētījumos uztvertā diskriminācija nav aplūkota ne dzimumu perspektīvā, ne arī saistībā ar integrāciju mītnes valstî.

Šìs nodaḷas galvenais pētnieciskais jautājums ir: kādi faktori palielina darbavietā uztvertās diskriminācijas varbūtību augsti kvalificētu sieviešu emigrantu vidū ārvalstīs?

Lai atbildētu uz šo jautājumu, izmantoti ESF projekta "Latvijas emigrantu kopienas: nacionālā identitāte, transnacionālās attiecības un diasporas politika” dati. Analīzē ir aplūkotas tādas faktoru grupas kā sociāldemogrāfiskie rādītāji, emigrantu ekonomiskās integrācijas rādītāji un piederības sajūta mītnes zemei un Latvijai. Analīzes nolūkiem izveidota apakšizlase, kurā iekḷautas Latvijas pirmās paaudzes emigrantes ar augstāko izglītību $(N=2332)$, kuras aptaujas laikā strādāja. 
Jēdziens “uztvertā diskriminācija” attiecas uz situācijām, kad indivīds uzskata, ka pret viṇu ir izturējušies netaisnīgi, un šajā nodaḷā tas vienmēr attieksies uz diskrimināciju darbavietā. Uztvertā diskriminācija ne vienmēr nozīmē patiešām objektīvu diskriminējošu darbību, par kuru varētu vērsties tiesā. Tā drīzāk ir netaisnības sajūta, indivīda subjektīvā uztvere, kas dažkārt ir balstīta uz nepilnīgu informāciju, bet kvantitatīvā aptaujā visas situācijas detaḷas nav iespējams noskaidrot. Vienlaikus subjektīvā situācijas interpretācija noteiktos gadījumos ir arī objektīvi diskriminācijas gadījumi, bet tie šajā nodaḷā padziḷināti netiks aplūkoti, pētniecisko lauku norobežojot un analīzi vēršot tikai uz uztvertās diskriminācijas fenomenu.

Dažādās uzṇemošajās valstīs ir atšķirīgas antidiskriminācijas politikas un politikas, kas vērstas uz migrantu integrāciju. Tās determinē noteiktu migrācijas pieredzes kontekstu makrolīmenī gan attiecībā uz augsti kvalificētiem migrantiem, gan arī viṇu darba devējiem. Migrācijas politikas dzimuma perspektīvā ir analizējuši daudzi pētnieki (Boucher \& Cerna, 2014; Cerna, 2011; Kofman, 2014; Triadafilopoulus, 2013). Viṇu iestrādes l̦auj skaidrāk interpretēt pētījuma rezultātus noteiktos kontekstos. Arī šajā analīzē ir pievērsta uzmanība atšķirī̄bām uztvertās diskriminācijas ziṇā dažādu valstu kontekstos.

Nodaļas sākumā ir sniegts ieskats galvenajās atziṇās no iepriekš veiktajiem pētījumiem par sieviešu migrāciju un diskriminācijas pieredzi. Turpinājumā aplūkoti pieejamie dati par augsti kvalificētu sieviešu migrāciju un to galvenie raksturojošie rādītāji. Pētījuma datu analīzes sadaḷu ievada analīzes datu un pieejas raksturojums. Analīzes rezultātu izklāstam seko diskusija par pētījuma rezultātiem un galvenie secinājumi.

\subsection{IEPRIEKŠ VEIKTO PĒTĪJUMU GALVENĀS ATZIN̦AS UN PĀRBAUDEI IZVIRZITTĀS HIPOTĒZES}

Pētījumos ir atklāts, ka, neskatoties uz relatīvi labvēlīgāko situāciju, arī augsti kvalificētas migrantes saskaras ar diskrimināciju, zemāku atalgojumu, nedrošiem līguma nosacījumiem, zināšanu neatbilstību darba tirgus prasībām un nereti arī darbu, kas neatbilst kvalifikācijai (Grigoleit-Richter, 2017). Piemēram, augsti kvalificēti imigranti OECD valstīs gandrīz divas reizes biežāk ir pārāk kvalificēti viṇu veiktajam darbam salīdzinājumā ar mītnes zemes pamatiedzīvotājiem (OECD/EU, 2015). Vienlaikus migranti paši ne vienmēr uztver noteiktas prakses kā diskriminējošas, jo viṇu iespējas uzṇemošajā valstī, saskaroties ar diskriminējošām praksēm, tik un tā ir labākas nekā izcelsmes 
valstī (Waters \& Kasinitz, 2013). Jāatzīmē, ka salīdzinoši zems sieviešu diskriminācijas līmenis uzṇemošajās valstīs ir arī būtisks pievilkšanas faktors, kādēḷ augsti kvalificētas sievietes pārceḷas uz dzīvi šajās valstīs, jo sievietes migrācijas gadījumā labprātāk izvēlas tās valstis, kur tām ir vairāk iespēju un tiesību (Ferrant \& Tuccio, 2015).

Migrantu diskriminācijas pētījumi, kas vērsti uz saistības noskaidrošanu starp uztverto diskrimināciju un integrāciju uzṇemošajā valstī, piedāvā vairākas teorētiskās perspektīvas (Portes, Parker, \& Cobas, 1980; Aguirre, Saenz, \& Hwang, 1989; Estrada, Tsai, \& Chandler, 2008; Vancluysen \& Van Craen, 2010). Viena no agrīnajām teorijām, kas aplūko asimilācijas un diskriminācijas korelāciju, ir asimilācijas teorija, ko izstrādājis Miltons M. Gordons (Milton M. Gordon) (1964). Saskaṇā ar viṇa pieeju asimilācijai ir vairākas pakāpes, un augstākais asimilācijas līmenis ir sasniegts tajā gadījumā, kad vairs nav savstarpēju aizspriedumu, diskriminācijas, vērtību un varas attiecību konflikta. M. Gordons un viṇa sekotāji pieṇem, ka, asimilējoties uzṇemošās valsts dominējošajā grupā, migrantu minoritātes mazāk saskaras ar uztverto un reālo diskrimināciju, jo tad, ja migranti pārvalda mītnes zemes valodu, kultūras normas un vērtības, dominējošā grupa tos labāk pieṇem un diskriminācija samazinās.

Citu teorētisko pieeju piedāvā A. Portess ar saviem kolēǵiem (Portes, Parker, \& Cobas, 1980), kuri uzskata tieši pretēji: jo vairāk migranti integrējas uzṇemošajā sabiedrībā, jo labāk viṇi izprot un uztver nevienlīdzīgo attieksmi. Pētījumā par kubiešu un meksikāṇu imigrantiem ASV viṇi pārbaudīja divas konkurējošas hipotēzes: asimilācijas teorijas hipotēzi, ka diskriminācijas uztvere, integrējoties uzṇemošajā valstī, mazinās, un konflikta apzināšanās teorijas (angl. - conflict consciousness theory) hipotēzi, ka diskriminācijas uztvere ar laiku paaugstinās. Viṇu pētījums apstiprina konflikta apzināšanās teorijas hipotēzi, jo, labāk saprotot valodu un konkrētās kultūras un sociālās normas, migranti labāk spēj novērtēt savu situāciju uzṇemošās valsts stratifikācijas sistēmā (Portes, Parker, \& Cobas, 1980: 220). Viṇu pētījums balstās uz kubiešu un meksikāṇu aptaujām: pirmā aptauja veikta īsi pēc viṇu ierašanās ASV, bet otrā aptauja - trīs gadus vēlāk.

Balstoties uz diskusiju starp divām konkurējošām teorijām jautājumā par uztverto diskrimināciju un integrāciju uzṇemošajā valstī, turpmākajā analīzē tiks pārbaudīta šāda hipotēze: jo ciešāk Latvijas emigrantes jūtas piederīgas mītnes valstij, jo mazāk tās uztver diskrimināciju, un otrādi. Tās Latvijas emigrantes, kas jūtas mazāk piederīgas mītnes valstij, ar lielāku varbūtību izjūt netaisnīgu vai diskriminējošu attieksmi. Iespējas korekti pārbaudīt 
konflikta apzināšanās teorijas piedāvāto modeli šajā gadījumā ir ierobežotas, jo tam būtu nepieciešami citi dati. A. Portess ar kolēgiem (Portes, Parker, \& Cobas, 1980) izmantoja divas aptaujas, aptaujājot vienus un tos pašus indivīdus gan īsi pēc ierašanās ASV, gan pēc trīs gadiem. Par Latvijas emigrantiem šãdi dati nav pieejami, tādēḷ galvenais uzsvars likts uz asimilācijas hipotēzes pārbaudi.

Kā atsevišķs analīzes aspekts turpinājumā aplūkota uztvertā diskriminācija Latvijas emigranšu vidū un tās saistība ar atgriešanās plāniem. Saskaṇā ar neoklasiskās ekonomikas atziṇām migranti tiek aplūkoti kā "ienākumu maksimalizētāji”, kas galvenokārt vēlas paaugstināt savus ienākumus. Līdz ar to plānotās migrācijas neveiksme, tajā skaitā sastapšanās ar netaisnīgu attieksmi un diskrimināciju, var būt saistīta ar vēlmi atgriezties izcelsmes valstī (Todaro, 1969; Constant \& Massey, 2002). Neapmierinātība ar uztverto diskrimināciju var sekmēt arī to, ka aktualizējas piederības sajūta izcelsmes valstij, tādēl teorētiski var sagaidīt, ka tās emigrantes, kas plāno atgriezties Latvijā un izjūt ciešāku piederību Latvijai, jūtas vairāk diskriminētas mītnes zemē.

Citur veiktie pētījumi atklāj, ka sociāli kulturālā integrācija dažādos kontekstos atšḳiras dažādās valstīs un nozarēs atkarībā no konkrētajās valstīs un nozarēs īstenotās politikas (Mulholland \& Ryan, 2014). Tādēl analīzē kā iespējamie faktori, kas nosaka uztvertās diskriminācijas pazīmi, iekḷauta ne tikai piederības sajūta mītnes valstij, bet arī dažādi sociāldemogrāfiskie rādītāji, tajā skaitā konkrētā mītnes valsts un nodarbinātības nozare, kā arī migrantu ekonomiskās situācijas vērtējums.

\subsection{STRĀDĀJOŠAS LATVIJAS SIEVIETES AR AUGSTĀKO IZGLITTĪBU EMIGRĀCIJĀ: RAKSTUROJUMS}

Raksturojot augsti izglītotās Latvijas strādājošās sievietes emigrācijā, nav izmantojami statistikas dati, jo tie nesniedz emigrantu raksturojumu pēc izglītības un nodarbinātības. Tādēḷ šajā gadījumā vispilnīgāko informāciju iespējams saṇemt no aptaujas datiem, kas iegūti ESF projektā "Latvijas emigrantu kopienas: nacionālā identitāte, transnacionālās attiecības un diasporas politika”. Šajā pētījumā dati tika iegūti, aptaujājot 14068 Latvijas emigrantus. Lai raksturotu augsti izglītotās Latvijas strādājošās sievietes emigrācijā, tika izveidota aptaujas apakšizlase, kurā iekḷautas tikai tās Latvijas emigrantes, kas ir pirmās paaudzes aizbraucējas ar augstāko izglītîbu un kas aptaujas veikšanas brīdī strādāja uzṇemošajā valstī. Analīzē izmantotās apakšizlases lielums 


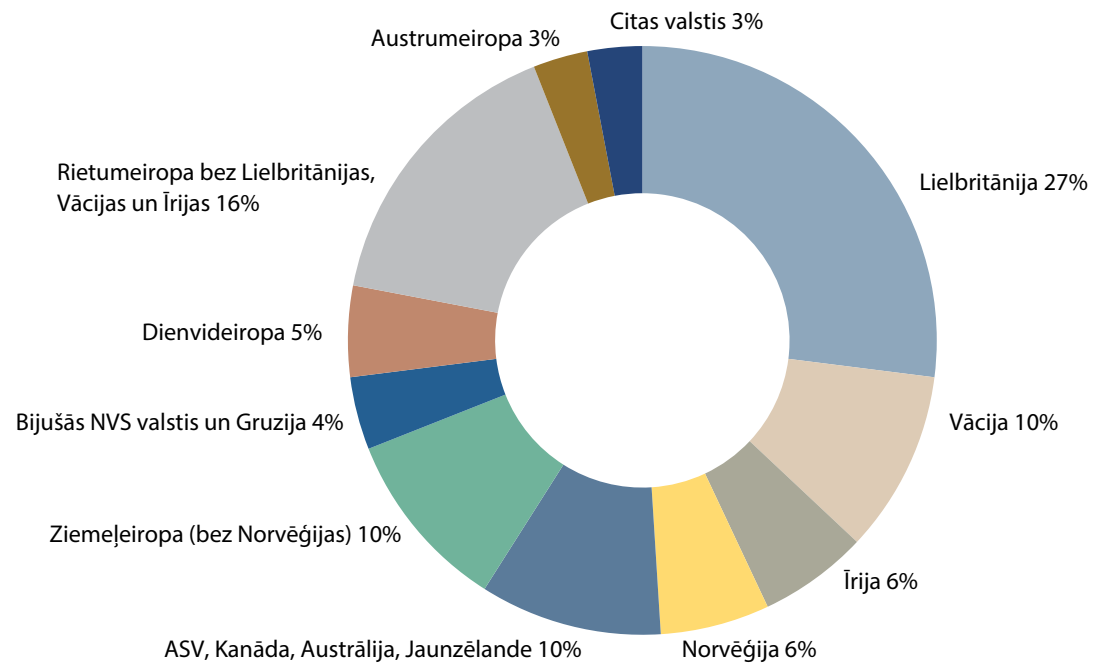

5.1. attēls. Latvijas sievietes ar augstāko izglītību emigrācijā: mītnes valsts $(N=2332)$

ir 2332 respondentes. Lielākais augsti izglītoto Latvijas sieviešu īpatsvars emigrācijā ir Lielbritānijā, bet salīdzinoši daudz Latvijas izglītoto emigranšu ir arī Ziemel̦valstīs (16\%) un Vācijā (10\%) (5.1. attēls).

Emigrējušo Latvijas augsti izglītoto sieviešu vecums ir salīdzinoši ḷoti neliels - 50\% sieviešu ir vecumā no 20 līdz 34 gadiem, 26\% vecumā no 35 līdz 44 gadiem, 17\% vecumā no 45 līdz 55 gadiem, un tikai 7\% ir vecākas par 55 gadiem. 59\% augsti izglītoto Latvijas sieviešu emigrācijā dzīvo kopā ar savu partneri, 29\% ir bērni. Emigrācijas laika ziṇā lielākā daḷa šo sieviešu ir nesenas emigrantes: 54\% ir emigrējušas pēc 2008. gada, 24\% laikā no 2004. līdz 2008. gadam, un 21\% - pirms 2004. gada. Gandrīz divām trešdaḷām aptaujāto sieviešu ir bakalaura grāds, 33\% ir ieguvušas maǵistra grādu, 2\% ir ieguvušas doktora grādu. Kopumā no visām apakšizlasē iekḷautajām sievietēm $6 \%$ ir ieguvušas maǵistra vai doktora grādu STEM jomās. Visu apakšizlasē aptaujāto sieviešu sadalījums pēc iegūtās izglītības jomas atklāj, ka vislielākais īpatsvars ir ieguvušas izglîtību sociālajās zinātnēs, komerczinībās vai tiesībās (44\%). Otrajā vietā ir humanitārās zinātnes un mākslas (21\%). Trešo un ceturto vietu dala izglītīibas zinātne (11\%) un veselības aprūpe (11\%). Nodarbinātības jomas emigrācijā atklāj, ka lielākais izglītoto sieviešu īpatsvars strādā tirdzniecībā, ēdināšanā un izmitināšanā (20\%). Otrajā vietā ir veselība un sociālā aprūpe (16\%). Trešajā un ceturtajā vietā ir izglītîba (10\%) un 


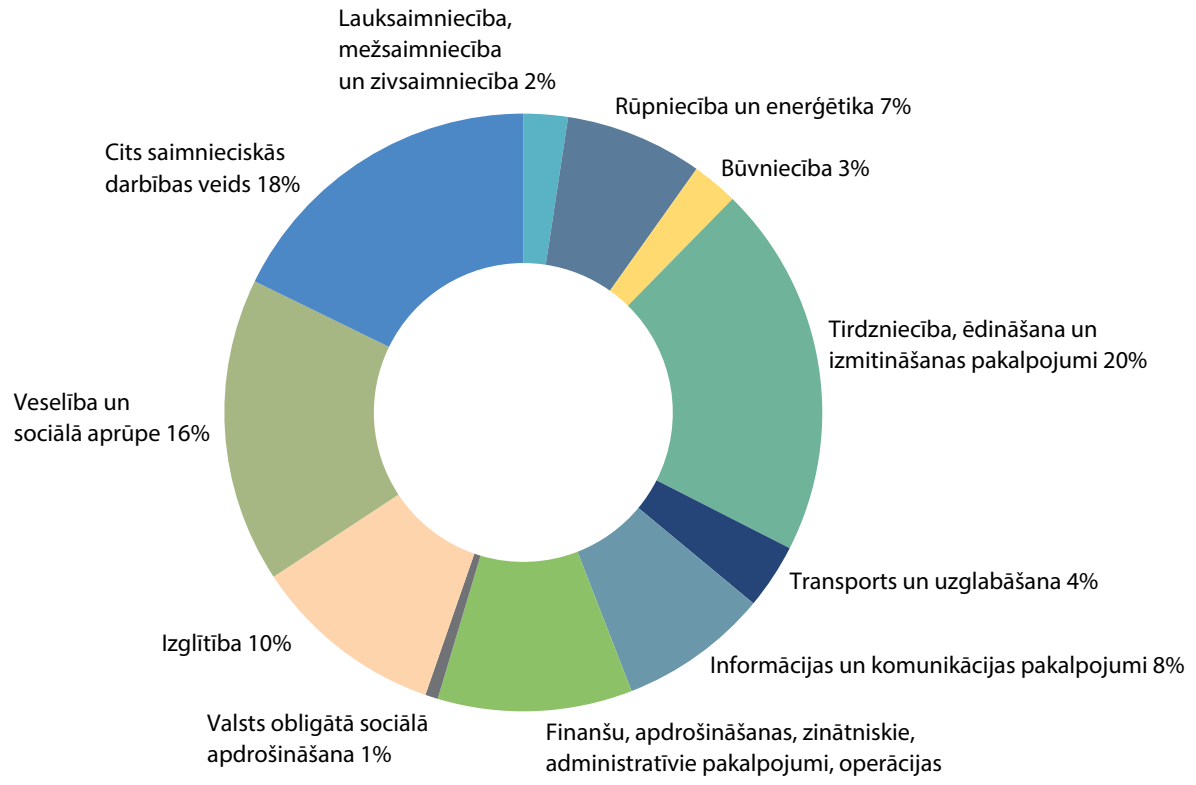

5.2. attēls. Latvijas sievietes ar augstāko izglìtību emigrācijā: nodarbinātības joma, $\%$ no konkrēti sniegtajām atbildēm $(N=2043)$

finanšu, apdrošināšanas, zinātniskie, administratīvie pakalpojumi, nekustamais īpašums (11\%) (5.2. attēls).

Interesantas atšḳirības sieviešu vidū atklāj aptaujā noskaidrotās pieejas darba atrašanā (5.3. attēls). Kopumā var identificēt četrus galvenos veidus, kā cilvēki parasti atrod darbu emigrācijā: (1) pieteikšanās konkursā vai pieteikšanās uz vakanci pēc sludinājuma; (2) ar draugu vai radu palīdzību; (3) ar darbā iekārtošanas firmu palīdzību; (4) ar mītnes zemes nodarbinātības dienestu palīdzību. Aptaujas dati atklāj, ka sievietes, kas ieguvušas maǵistra un doktora grādu STEM jomās (līdzīgi kā vīrieši ar līdzvērtīgu izglīitību), darbu atrod, piesakoties konkursā vai uz vakanci pēc sludinājuma (47\%). Citas sievietes, jo īpaši tās, kurām nav augstākās izglītības, darbu lielākoties atrod ar draugu vai radu palīdzību (52\%). Savukārt attiecībā uz uzṇēmējdarbības aktivitātēm sieviešu izglìtībai nav tik lielas nozīmes. Kopumā lielākā daḷa aptaujāto sieviešu ar augstāko izglîtību strādā algotu darbu, un tikai 4\% ir uzṇēmējas. Vīriešu vidū uzṇēmēju ar augstāko izglītību ir salīdzinoši vairāk (5.4. attēls). Aptaujas dati arī atklāj, ka Latvijas emigrantēm labvēlīgāka situācija uzṇēmējdarbības uzsākšanai ir tādās valstīs kā ASV, Kanāda, Austrālija, 


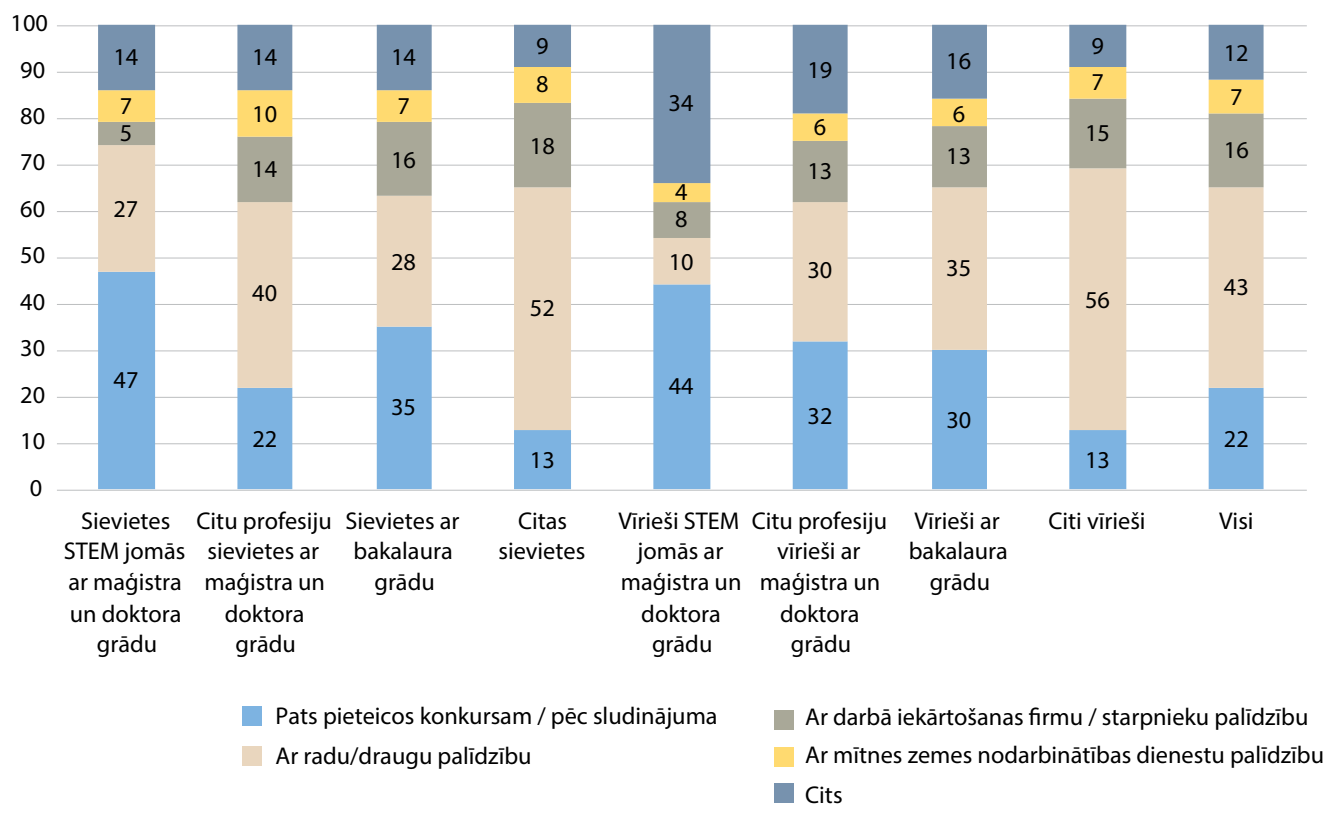

5.3. attēls. Darba atrašana: dažādu grupu salīdzinājums $(N=6209)$

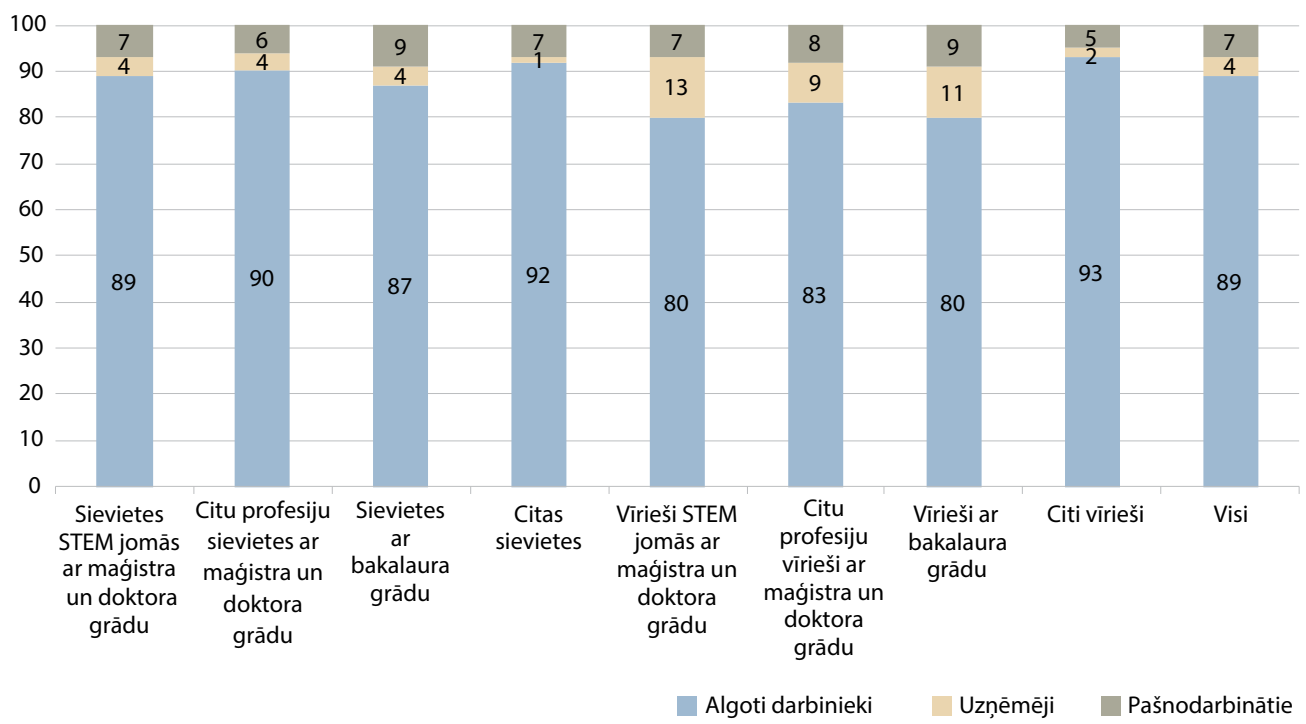

5.4. attēls. Uzṇēmējdarbība: dažādu grupu salīdzinājums $(N=6209)$ 


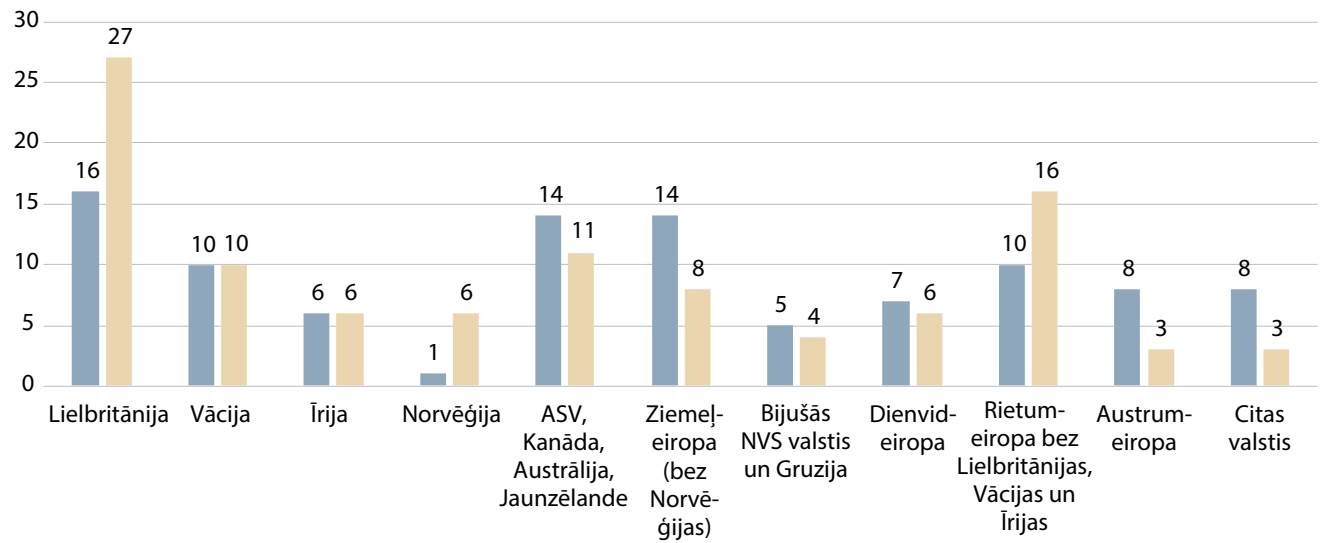

Sievietes uzṇēmējas ar augstāko izglītību, $N=83$

Sievietes ar augstāko izglītību, nav uzñēmējas, $N=2122$

5.5. attēls. Latvijas sievietes ar augstāko izglītību emigrācijā: uzṇēmējdarbības

uzsākšana dažādās valstīs $(N=2332)$

134 Jaunzēlande, kā arī Ziemeḷeiropā (bet ne Norvēǵijā). Salīdzinājumam Lielbritānijā, kur dzīvo visvairāk Latvijas emigranšu, emigrācijas nosacījumi ievērojami mazāk ir sekmējuši savas uzṇēmējdarbības uzsākšanu nekā citur, jo ir vislielākā starpība starp to sieviešu īpatsvaru, kuras ir uzsākušas uzṇēmējdarbību, un to, kuras nav uzsākušas (5.5. attēls).

Vēl viens rādītājs, kas raksturo strādājošo augsti izglītoto sieviešu situāciju emigrācijā, ir iegūtās kvalifikācijas izmantošana (5.6. attēls). Šajā ziṇā būtiskas atškirības vērojamas arī attiecībā uz sievietēm, kas ieguvušas mağistra un doktora grādu STEM jomās (līdzīgi kā vīriešiem ar līdzvērtīgu izglītību). No sievietēm ar maǵistra un doktora grādu STEM jomās 85\% aptaujāto izmanto savu kvalifikāciju, strādājot emigrācijā (no vīriešiem ar līdzvērtīgu izglītîbu - 90\%).

Savukārt uztvertā diskriminācija pētījumā mēeīta ar sešiem indikatoriem, no kuriem pilnīgi visos sievietes ar augstāko izglītību visretāk norādīja, ka ir sastapušās ar netaisnīgu attieksmi (5.7. attēls). No augstāko izglītību ieguvušajām sievietēm 9\% respondentu norādīja, ka par līdzīgu darbu ir saṇēmušas mazāku atalgojumu nekā vietējie iedzīvotāji. 8\% atbildēja, ka ir izjutušas netaisnību, jo viṇām vienmēr jāiet atvalịnājumā "sliktajā” gadalaikā. Līdzīgs skaits aptaujāto (5\%) norāda, ka viṇām biežāk nekā vietējiem uzdod neizdevīgus un/vai nepatīkamus darbus un izvirza striktākas darba disciplīnas 


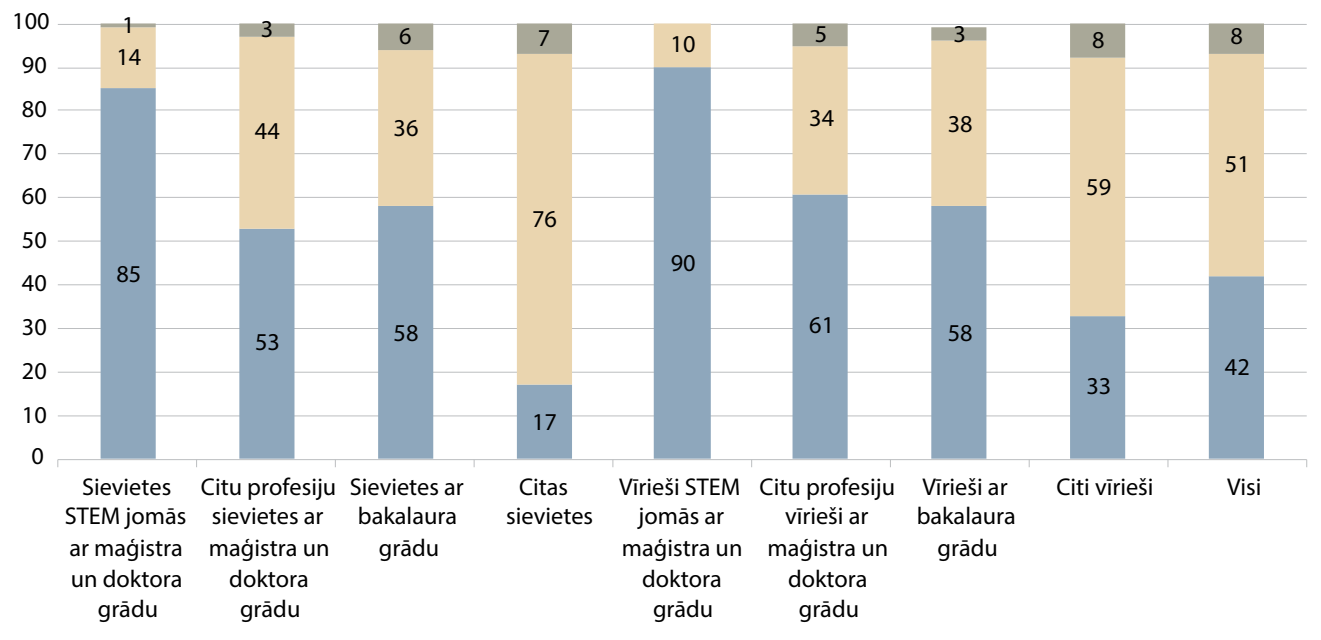

\section{6. attēls. Kvalifikācijas izmantošana emigrantu vidū: dažādu grupu salīdzinājums $(N=6209)$}

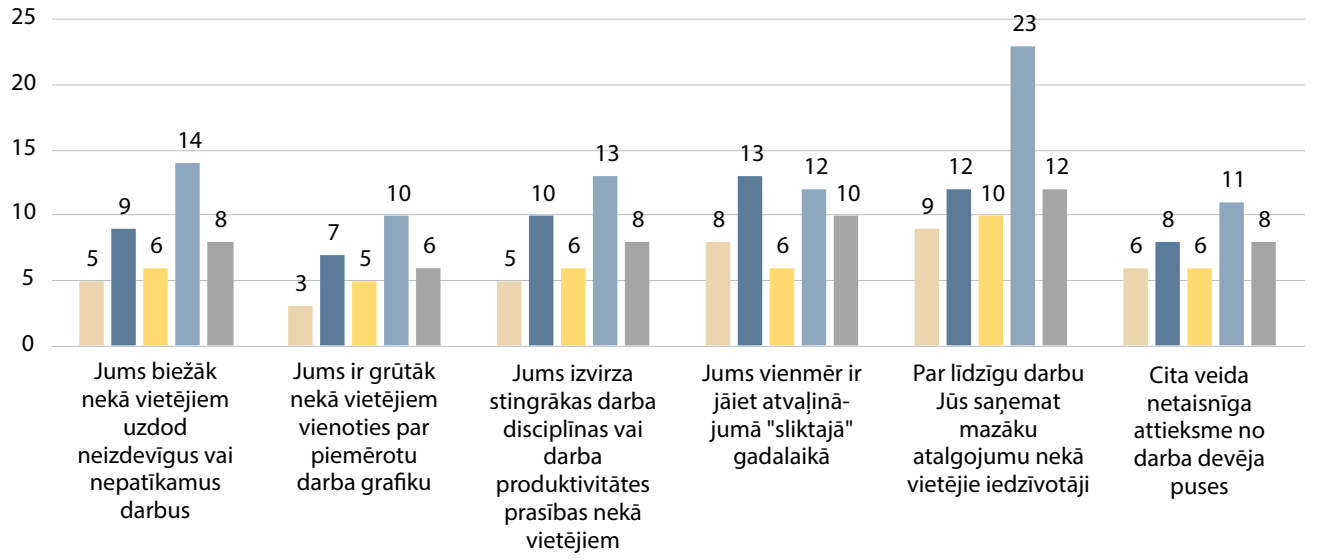

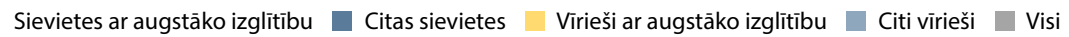

\section{7. attēls. Kvalifikācijas izmantošana emigrantu vidū: dažādu grupu salīdzinājums} $(N=6209)$ 
un/vai darba produktivitātes prasības nekā vietējiem. Jāuzsver, ka salīdzinoši visbiežāk par uztverto diskrimināciju ir norādījuši vīrieši, kam nav augstākās izglītības, tad seko sievietes, kam nav augstākās izglītības, bet vismazāk netaisnīgu attieksmi ir izjutušas sievietes ar augstāko izglītību.

Summārais uztvertās diskriminācijas mainīgais parāda, ka kopumā 21\% aptaujāto sieviešu ar augstāko izglītību ir izjutušas netaisnīgu attieksmi kādā no aptaujā iekḷautajām diskriminācijas situācijām. Padziḷināta uztvertās diskriminācijas analīze augsti izglītoto sieviešu vidū un to ietekmējošo faktoru izpēte sniegta turpinājumā.

\subsection{ANALİZES METODES}

\section{ATKARĪGO MAINĪGO APRAKSTS}

Lai izpētītu uztvertās diskriminācijas fenomenu emigrējušo augsti izglītoto Latvijas sieviešu vidū un faktorus, kas to nosaka, izmantota binārās logistiskās regresijas analīze. Par atkarīgajiem mainīgajiem regresijas analīzē izvēlēti trīs main̄̄gie - dažādi indikatori, kas raksturo uztverto diskrimināciju emigrantu vidū: (1) jums biežāk nekā vietējiem uzdod neizdevīgus un/ vai nepatīkamus darbus (uztvertā darba uzdevumu diskriminācija); (2) jums vienmēr jāiet atvaḷinājumā "sliktajā” gadalaikā (uztvertā atvaḷinājumu diskriminācija); (3) par līdzīgu darbu jūs saṇemat mazāku atalgojumu nekā vietējie iedzīvotāji (uztvertā algu diskriminācija). Atbilstoši tika veiktas trīs binārās loǵistiskās regresijas analīzes. Galvenie iemesli, kādēḷ izvēlēti tieši šie indikatori, saistīti ar to minēšanas biežumu.

\section{NEATKARĪGO MAINITGO APRAKSTS}

Pirmā neatkarīgo mainīgo grupa analīzē raksturo kontrolmainīgos, kas vienlaikus ir arī galvenie sociāldemogrāfiskie rādītāji: vecums, nodarbinātības statuss, izglìtība STEM jomās, mītnes valsts un nodarbinātības joma. Respondentu vecums ir robežās no 20 līdz 75 gadiem (vidējais aritmētiskais 37,15). Nodarbinātības statusa raksturošanai izmantoti divi main̄̄gie: (1) pašnodarbinātas vai strādājošas ğimenes uzṇēmumā; (2) uzṇēmējas (5.1. tabula). Tas palīdzēs noskaidrot, vai šo divu grupu pieredze atšķiras no pieredzes, kāda ir algotām darbiniecēm. Ja nav īpaši norādīts uz kādām īpatnībām, šeit un turpmāk visi mainīgie kodēti tādējādi, ka 0 ir nē, bet 1 ir jā jeb atbilstība pazīmei. Kopumā aptaujā piedalījās 23\% sieviešu, kas izglīī̄bu ieguvušas STEM jomās. Par augsti kvalificētām STEM jomās ir noteiktas tās speciālistes, kam 
ir maǵistra vai doktora grāds (6\%), un atbilstoši ir izveidots mainīgais, kas raksturo, ka sievietes ir augsti kvalificētas šajās jomās. Mītnes valsts mainīgie iekḷauti, lai noskaidrotu, vai strādāšana noteiktā mītnes valstī ietekmē uztvertās diskriminācijas varbūtību no Latvijas emigrējušo augsti izglītoto sieviešu vidū. Līdz̄̄gi nodarbinātības jomas mainīgie ir iekḷauti, lai noskaidrotu, vai kādā no nodarbinātības jomām varbūtība saskarties ar uztverto diskrimināciju ir augstāka. Kopumā analīzē ir iekḷautas deviṇas nodarbinātîbas jomas.

Šajā analīzē ir nodalīta migrantu ekonomiskā integrācija un sociāli kulturālā integrācija. Ekonomiskā analīze pieejamo mainīgo ziṇā attiecas uz ienākumu pašvērtējumu un to, vai no Latvijas emigrējušās sievietes ar augstāko izglîtību strādā atbilstoši iegūtajai kvalifikācijai vai izglītībai. Savukārt sociāli kulturālā integrācija vairāk attiecas uz main̄̄gajiem, kas raksturo migranta piederības sajūtu mītnes valstij. Apzinoties to, ka jēdziens "integrācija” ir l̦oti strīdīgs un dažādi interpretēts, šajā analīzē autore norobežojas no kompleksajām diskusijām par jēdzieniem “asimilācija” un “integrācija” un lieto operacionālu definīciju - saskaṇā ar to integrācija tiek aplūkota kā migrantu adaptācija un iekḷaušanās vairākuma sabiedrībā (Haas \& Fokkema, 2011).

Ekonomiskās integrācijas mainīgie, kas raksturo augsti izglītoto Latvijas emigranšu situāciju darba tirgū, ir vairāki. Vispirms jānorāda, ka visas analīzē iekḷautās Latvijas emigrantes ar augstāko izglītîbu ir strādājošas, jo uztvertās diskriminācijas rādītāji attiecas tikai uz darba diskrimināciju. 11\% no šīm sievietēm ir saskārušās ar grūtībām attiecībā uz Latvijā iegūtās izglītības vai profesionālās kvalifikācijas atzǐšanu mītnes zemē. Iespējams, tas paaugstina uztvertās diskriminācijas varbūtību, tādēḷ analīzē ir iekḷauts mainīgais, kas raksturo šo grupu. Viena no plaši diskutētām problēmām, ar ko saskaras izglītotie migranti, ir “smadzeṇu izniekošana” (Bauder, 2003; Pietka, Clark, \& Canton, 2013; Trevena, 2013; Hazans, 2015; OECD/EU, 2015). Šajā analīzē tās ietekme pārbaudīta, iekḷaujot mainīgo "lielā mērā izmantoju savu kvalifikāciju/izglītību pašreizējā pamatdarbā”. No apakšizlasē iekḷautajām Latvijas emigrantēm 52\% uzskata, ka lielā mērā izmanto savu izglītību pašreizējā darbā. Vairāk nekā puse aptaujāto Latvijas emigranšu ar augstāko izglītību (52\%) mītnes zemē ir uzlabojušas savas profesionālās zināšanas vai valodas zināšanas dažādos kursos vai apmācībās. Šāds mainīgais atklās, vai profesionālās kvalifikācijas celšanas pieredze samazina vai palielina uztvertās diskriminācijas varbūtîbu.

Dažās valstīs nelegālā nodarbinātība, kad migranti strādā bez rakstiskiem līgumiem, ir viens no faktoriem, kas var palielināt uztvertās diskriminācijas varbūtību. Lai to pārbaudītu, analīzē ir iekḷauts mainīgais par rakstisku līgumu 
ar darba devēju mītnes zemē. Saskaṇā ar aptaujas rezultātiem 76\% strādājošo sieviešu ar augstāko izglìtību ir rakstisks līgums ar darba devēju.

Aptaujā bija vairāki jautājumi par emigrantu ienākumiem. Analīzes nolūkiem iekḷautie main̄̄gie raksturo augsti izglītoto Latvijas emigrantu situāciju mītnes zemē aptaujas brīdī un Latvijā pirms aizbraukšanas. Kopumā grūtības "savilkt galus”, nomaksāt nepieciešamos izdevumus ir apmēram 9\% apakšizlasē aptaujāto. Ievērojami lielākai daḷai (68\%) bija grūtības "savilkt galus" Latvijā pirms aizbraukšanas. Šie divi mainīgie atklās, vai grūtības ar ienākumiem mītnes valstī un Latvijā palielina uztvertās diskriminācijas varbūtību. Vēl analīzē ir iekḷauts mainīgais "plāno atgriezties Latvijā tuvāko piecu gadu laikā”, kas parādīs, vai pastāv korelācija starp uztverto diskrimināciju un vēlmi atgriezties Latvijā.

Trešā mainīgo grupa ir saistīta ar piederības sajūtu mītnes valstij un piederības sajūtu Latvijai. Aptaujas anketā bija iekḷauti daudzi mainīgie, kas raksturo gan piederības sajūtu mītnes valstij, gan piederības sajūtu Latvijai. Main̄̄go skaita samazināšanai izmantota faktoru analīze. Lai noteiktu faktoru, kas raksturo piederības sajūtu mītnes valstij, iekḷauti seši main̄̄gie (5.2. tabula). Līdzīgs skaits mainīgo iekḷauts arī, lai noteiktu piederības sajūtas Latvijai faktoru. Divu atsevišķo faktoru analǐžu rezultātā tika iegūti divi jauni mainīgie. Viens main̄̄gais ar faktora vērtībām raksturo piederību mītnes valstij (faktora izskaidrojošais potenciāls 34\%), bet otrs - piederības sajūtu Latvijai (faktora izskaidrojošais potenciāls 32\%).

5.1. tabula. Atkarīgo un neatkarīgo mainīgo deskriptīvā statistika $(N=2332)$

\begin{tabular}{llc}
\hline & $\%$ & $N$ \\
\hline Atkarīgie mainīgie & & \\
\hline $\begin{array}{l}\text { Jums biežāk nekā vietējiem uzdod neizdevīgus un/vai nepatīkamus darbus (uztvertā } \\
\text { darba uzdevumu diskriminācija) }\end{array}$ & 5 & 121 \\
\hline Jums vienmēr jāiet atvaḷinājumā "sliktajā” gadalaikā (uztvertā atvaḷinājumu diskriminācija) & 8 & 178 \\
\hline $\begin{array}{l}\text { Par līdzīgu darbu jūs saṇemat mazāku atalgojumu nekā vietējie iedzīvotāji (uztvertāà algu } \\
\text { diskriminācija) }\end{array}$ & 9 & 203 \\
\hline Neatkarīgie mainīgie & & \\
\hline Vecums (20-75 gadi; vidējais aritmētiskais 37,15) & & \\
\hline Pašnodarbinātas vai strādājošas ǵimenes uzñēmumā & 9 & 201 \\
\hline Uzṇēmējas & 3 & 73 \\
\hline Augsti kvalificētas STEM jomās ar maǵistra vai doktora grādu & 6 & 151 \\
\hline
\end{tabular}




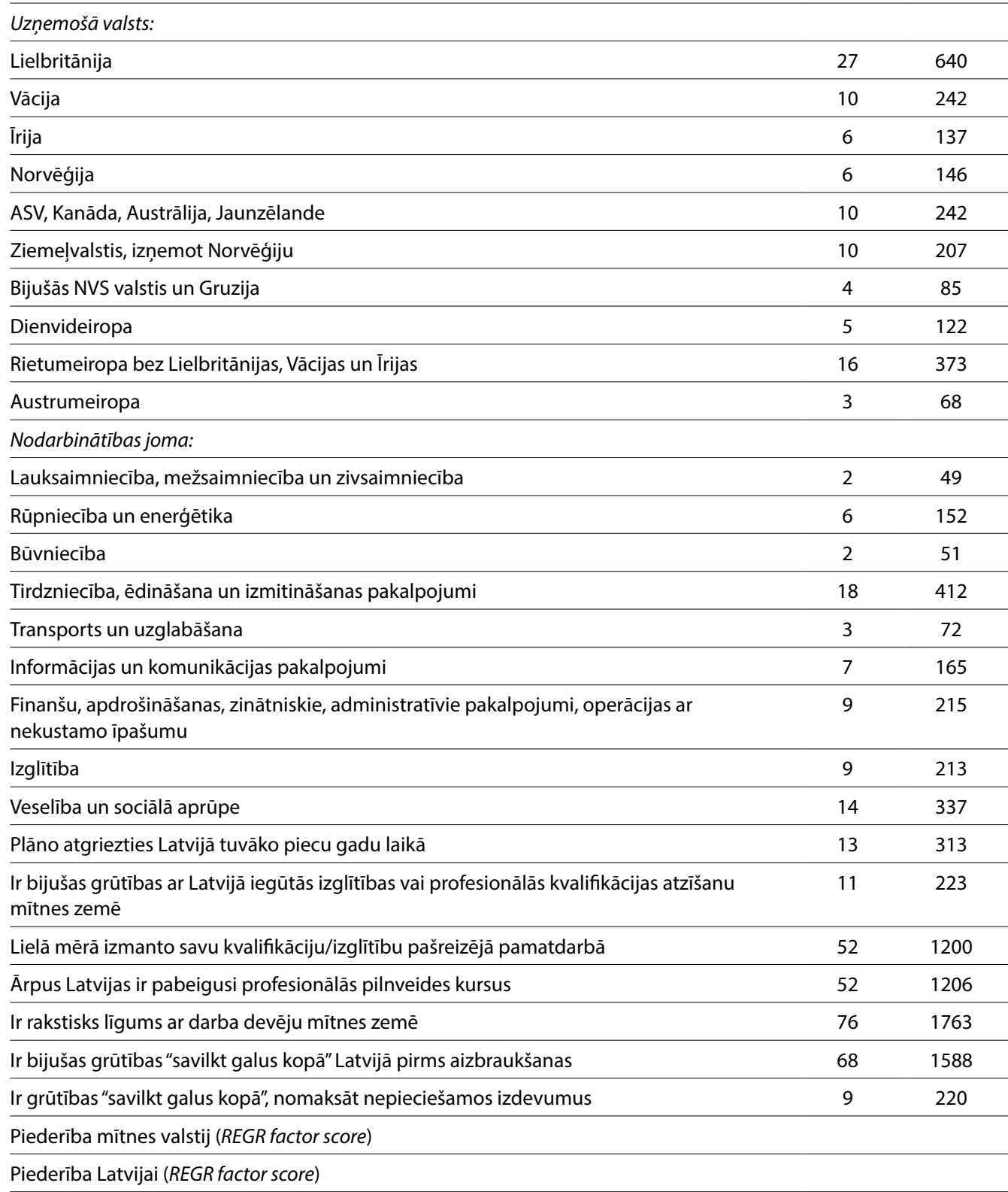


5.2. tabula. Mainīgie "piederība mītnes valstij" un "piederība Latvijai" (faktoru raksturojums)

\begin{tabular}{ll}
\hline Piederība mītnes valstij & \\
\hline Jūtas cieši vai ḷoti cieši saistīts ar valsti, kurā šobrīd dzīvo (1_jā) & 0,711 \\
\hline Jūtas ḷoti vai zināmā mērā piederīgs mītnes zemes iedzīvotājiem (1_jā) & 0,705 \\
\hline Regulāri seko līdzi notiekošajam mītnes zemē (1_jā, regulāri) & 0,636 \\
\hline Regulāri seko līdzi norisēm kultūras dzīvē mītnes zemē (1_jā, regulāri) & 0,489 \\
\hline Ir tuvi draugi starp “vietējiem” mītnes zemē (1_jā) & 0,475 \\
\hline Zina lielāko daḷu cilvēku savā apkaimē (1_jā) & 0,439 \\
\hline Ipašvērtība (Eigenvalue) & 2,065 \\
\hline Faktora izskaidrojošais potenciāls (Variance explained) (\%) & $34 \%$ \\
\hline
\end{tabular}

\begin{tabular}{ll}
\hline Piederība Latvijai & \\
\hline Jūtas cieši vai ḷoti cieši saistīts ar Latviju (1_jā) & 0,656 \\
\hline Jūtas l̦oti vai zināmā mērā piederīgs Latvijas iedzīvotājiem (1_jā) & 0,651 \\
\hline Regulāri seko līdzi norisēm kultūras dzīvē Latvijā (1_jā, regulāri) & 0,635 \\
\hline Regulāri seko līdzi notiekošajam Latvijā (1_jā, regulāri) & 0,596 \\
\hline Brauc uz Latviju vismaz reizi pusgadā (1_jā) & 0,476 \\
\hline Ir tuvi draugi, kas dzīvo Latvijā (1_jā) & 0,314 \\
\hline İpašvērtība (Eigenvalue) & 1,938 \\
\hline Faktora izskaidrojošais potenciāls (Variance explained) (\%) & $32 \%$ \\
\hline
\end{tabular}

\subsection{BINĀRĀS LOG̣ISTISKĀS REGRESIJAS ANALİZES REZULTĀTI}

Binārās loǵistiskās regresijas analīžu modeḷi par katru no trim analīzē iekḷautajiem uztvertās diskriminācijas veidiem atklāj, ka atšḳirīgi mainīgie ir nozīmīgi atšķirīgos uztvertās diskriminācijas gadījumos. Tas nozīmē, ka izvēlētā analīzes stratēǵija veikt atsevišķas analīzes ir pareizāka, nekā veikt vienu regresijas analīzi par summāro uztvertās diskriminācijas mainīgo. Binārās logistiskās regresijas analīzes trīs modeḷi ar galvenajiem faktoriem, kas ietekmē uztverto diskrimināciju, ir saīsināti apkopoti 5.3. tabulā. Regresijas modela raksturošanai izmantotā rādītāja Neigelkerkes $R^{2}{ }_{\mathrm{N}}$ vērtība attiecībā uz regresijas modeli par uztverto darba uzdevumu diskrimināciju ir 0,185, kas nozīmē, ka konkrētais regresijas analīzes modelis izskaidro 18,5\%. Neigelkerkes $R^{2}{ }_{\mathrm{N}}$ vērtība attiecībā uz regresijas modeli par uztverto atvaḷinājumu diskrimināciju ir 0,147, savukārt attiecībā uz regresijas modeli par uztverto 
darba algas diskrimināciju - 0,133. Turpinājumā analīzes rezultāti ir apkopoti trīs neatkarīgo mainīgo grupās: (1) sociāldemogrāfiskie rādītāji; (2) ekonomiskā integrācija un profesionālā izglītîba; (3) piederības sajūta mītnes valstij un Latvijai.

5.3. tabula. Uztvertās diskriminācijas determinanti: trīs binārās loǵistiskās regresijas analīzes modeḷi

\begin{tabular}{|c|c|c|c|c|c|c|c|c|c|}
\hline & \multicolumn{3}{|c|}{$\begin{array}{c}\text { Jums biežāk nekā vietējiem } \\
\text { uzdod neizdevīgus un/ } \\
\text { vai nepatīkamus darbus } \\
\text { (uztvertā darba uzdevumu } \\
\text { diskriminācija) }\end{array}$} & \multicolumn{3}{|c|}{$\begin{array}{c}\text { Jums vienmēr } \\
\text { jāiet atvalịnājumā } \\
\text { "sliktajā" gadalaikā } \\
\text { (uztvertā atvaḷinājumu } \\
\text { diskriminācija) }\end{array}$} & \multicolumn{3}{|c|}{$\begin{array}{c}\text { Par līdzīgu darbu } \\
\text { jūs sañemat mazāku } \\
\text { atalgojumu nekā vietējie } \\
\text { iedzīvotāji (uztvertā algu } \\
\text { diskriminācija) }\end{array}$} \\
\hline & B & S.E. & Sig. & B & S.E. & Sig. & B & S.E. & Sig. \\
\hline Vecums & 0,001 & 0,010 & 0,950 & 0,033 & 0,008 & 0,000 & 0,002 & 0,008 & 0,844 \\
\hline $\begin{array}{l}\text { Pašnodarbinātas vai } \\
\text { strādājošas ǵimenes } \\
\text { uzñēmumā }\end{array}$ & $-0,944$ & 0,476 & 0,047 & $-0,093$ & 0,464 & 0,842 & $-0,151$ & 0,330 & 0,649 \\
\hline Uzṇēmējas & $-18,319$ & 4359,378 & 0,997 & 0,496 & 0,556 & 0,373 & $-0,321$ & 0,527 & 0,543 \\
\hline $\begin{array}{l}\text { Augsti kvalificētas STEM } \\
\text { jomās ar maǵistra vai } \\
\text { bakalaura grādu }\end{array}$ & $-0,559$ & 0,620 & 0,367 & $-0,763$ & 0,489 & 0,119 & $-0,490$ & 0,418 & 0,241 \\
\hline \multicolumn{10}{|l|}{ Uzṇemošā valsts: } \\
\hline Lielbritānija & 0,313 & 0,775 & 0,687 & 0,464 & 0,627 & 0,459 & $-0,288$ & 0,513 & 0,575 \\
\hline Vācija & 0,831 & 0,806 & 0,303 & 0,723 & 0,653 & 0,268 & 0,548 & 0,533 & 0,304 \\
\hline Īrija & 0,568 & 0,850 & 0,504 & 0,737 & 0,676 & 0,275 & 0,029 & 0,580 & 0,960 \\
\hline Norvēǵija & 1,104 & 0,822 & 0,179 & 0,823 & 0,670 & 0,219 & $-0,058$ & 0,590 & 0,921 \\
\hline $\begin{array}{l}\text { ASV, Kanāda, Austrālija, } \\
\text { Jaunzēlande }\end{array}$ & 0,219 & 0,848 & 0,796 & $-2,337$ & 1,177 & 0,047 & $-0,227$ & 0,570 & 0,690 \\
\hline $\begin{array}{l}\text { Ziemel̦valstis, izṇemot } \\
\text { Norvēǵiju }\end{array}$ & 1,068 & 0,802 & 0,183 & 0,527 & 0,658 & 0,423 & 0,522 & 0,538 & 0,332 \\
\hline $\begin{array}{l}\text { Bijušās NVS valstis un } \\
\text { Gruzija }\end{array}$ & $-17,188$ & 4090,306 & 0,997 & $-1,014$ & 1,185 & 0,392 & $-1,730$ & 1,128 & 0,125 \\
\hline Dienvideiropa & 0,535 & 0,856 & 0,532 & 0,945 & 0,681 & 0,165 & $-0,249$ & 0,602 & 0,679 \\
\hline $\begin{array}{l}\text { Rietumeiropa bez } \\
\text { Lielbritānijas, Vācijas } \\
\text { un Īrijas }\end{array}$ & 0,224 & 0,802 & 0,780 & 0,490 & 0,637 & 0,442 & 0,501 & 0,512 & 0,327 \\
\hline Austrumeiropa & $-0,457$ & 1,274 & 0,720 & 0,682 & 0,808 & 0,399 & $-0,725$ & 0,878 & 0,409 \\
\hline \multicolumn{10}{|l|}{ Nodarbinātības joma: } \\
\hline $\begin{array}{l}\text { Lauksaimniecība, } \\
\text { mežsaimniecība un } \\
\text { zivsaimniecība }\end{array}$ & $-18,183$ & 5406,302 & 0,997 & 0,813 & 0,448 & 0,070 & 0,765 & 0,464 & 0,099 \\
\hline $\begin{array}{l}\text { Rūpniecība un } \\
\text { enerǵētika }\end{array}$ & 1,040 & 0,379 & 0,006 & $-0,033$ & 0,373 & 0,929 & 0,671 & 0,339 & 0,048 \\
\hline
\end{tabular}




\begin{tabular}{lccccccccc}
\hline Būvniecība & $-17,657$ & 5105,368 & 0,997 & $-1,075$ & 1,038 & 0,301 & 0,233 & 0,641 & 0,716 \\
\hline $\begin{array}{l}\text { Tirdzniecība, ēdināšana } \\
\text { un izmitināšanas } \\
\text { pakalpojumi }\end{array}$ & 0,418 & 0,319 & 0,190 & 0,704 & 0,245 & 0,004 & 0,559 & 0,250 & $\mathbf{0 , 0 2 6}$ \\
\hline $\begin{array}{l}\text { Transports un } \\
\text { uzglabāšana }\end{array}$ & 0,443 & 0,542 & 0,414 & 0,327 & 0,450 & 0,468 & $-0,003$ & 0,510 & 0,996 \\
\hline $\begin{array}{l}\text { Informācijas un } \\
\text { komunikācijas } \\
\text { pakalpojumi }\end{array}$ & 0,720 & 0,475 & 0,129 & $-0,826$ & 0,549 & 0,133 & 0,864 & 0,338 & $\mathbf{0 , 0 1 1}$ \\
\hline
\end{tabular}

Finanšu,

apdrošināšanas,

zinātniskie,

administratīvie

$\begin{array}{lllllllll}0,074 & 0,467 & 0,874 & 0,016 & 0,344 & 0,963 & 0,233 & 0,340 & 0,494\end{array}$

pakalpojumi, operācijas

ar nekustamo îpašumu

\begin{tabular}{llllllllll}
\hline Izglìtība & 0,432 & 0,397 & 0,277 & 0,174 & 0,318 & 0,583 & 0,328 & 0,321 & 0,307 \\
\hline $\begin{array}{l}\text { Veselība un sociālā } \\
\text { aprūpe }\end{array}$ & 0,399 & 0,339 & 0,239 & $-0,274$ & 0,291 & 0,348 & 0,625 & 0,258 & 0,015 \\
\hline
\end{tabular}

Plāno atgriezties Latvijā tuvāko piecu gadu laikā

$\begin{array}{lllllllll}0,293 & 0,264 & 0,266 & 0,256 & 0,241 & 0,286 & 0,633 & 0,205 & 0,002\end{array}$

Ir bijušas grūtības ar Latvijā iegūtās izglīīibas

142 vai profesionālās

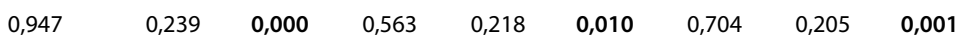
mītnes zemē

Lielā mērā izmanto savu kvalifikāciju/izglìīīu $-0,518 \quad 0,226 \quad 0,022 \quad-0,071$ pašreizējā pamatdarbā

Ārpus Latvijas ir pabeigušas profesionālās pilnveides $\begin{array}{lllll}0,893 & 0,227 & 0,000 & 1,041 & 0,193\end{array}$ $\begin{array}{lllll}0,893 & 0,227 & 0,000 & 1,041 & 0,193\end{array}$ 0,193 $0,000 \quad 0,632 \quad 0,171$ 0,000 kursus

Ir rakstisks līgums ar darba devēju mītnes zemē

Ir bijušas grūtības

"savilkt galus kopā" Latvijā pirms $0,183 \quad 0,696 \quad-0,406$ 0,174 0,020 aizbraukšanas

Ir grūtības "savilkt galus kopā", nomaksāt nepieciešamos 0,265 $0,009 \quad 0,225 \quad 0,329$

$0,494-0,620$

0,242

0,010 izdevumus

\begin{tabular}{lrrrrrrrrr}
\hline Piederība mītnes valstij & $-0,380$ & 0,106 & 0,000 & $-0,138$ & 0,086 & 0,111 & $-0,334$ & 0,082 & $\mathbf{0 , 0 0 0}$ \\
\hline Piederība Latvijai & 0,173 & 0,109 & 0,114 & $-0,143$ & 0,086 & 0,099 & 0,004 & 0,083 & 0,965 \\
\hline Konstante & $-4,296$ & 0,908 & 0,000 & $-5,214$ & 0,771 & 0,000 & $-3,163$ & 0,629 & 0,000 \\
\hline Neigelkerkes $R_{N}^{2}$ & 0,185 & & & 0,147 & & & 0,133 & & \\
\hline
\end{tabular}




\section{UZTVERTĀ DISKRIMINĀCIJA DARBĀ UN SOCIĀLDEMOGRĀFISKIE RĀDĪTĀJI}

Regresijas modelis attiecībā uz uztverto darba uzdevumu diskrimināciju parāda, ka vecums vai mītnes valsts to būtiski neietekmē. Kontrolējot citus main̄̄gos, ietekme uz uztverto darba uzdevumu diskrimināciju vērojama saistībā ar nodarbinātību dažādās nozarēs. Sievietes, kas strādā rūpniecības un enerǵêtikas nozarē, ar lielāku varbūtību ir pieredzējušas uztverto darba uzdevumu diskrimināciju. Šāda varbūtība mazinās, ja sievietes ir pašnodarbinātas vai strādā gimenes uzṇēmumā (5.3. tabula).

Regresijas analīzes rezultāti atšḳiras divos citos analīzes modeḷos. Uztvertās atvaḷinājumu diskriminācijas modelis atklāj, ka respondentu vecumam šajā gadījumā ir nozīme, jo gados vecākas sievietes ar lielāku varbūtîbu ir pieredzējušas to, ka vienmēr jāiet atvalinājumā "sliktajā” gadalaikā. Mazāka varbūtība pieredzēt uztverto atvalịnājumu diskrimināciju ir tām Latvijas emigrantēm, kas dzīvo ASV, Kanādā, Austrālijā vai Jaunzēlandē. Lielāka varbūtība pieredzēt to, ka vienmēr jāiet atvalinājumā "sliktajā” gadalaikā, ir tām Latvijas emigrantēm, kas strādā tirdzniecības, êdināšanas un izmitināšanas pakalpojumu jomā.

Pretēji gaidītajam, regresijas modelis attiecībā uz uztverto darba algu diskrimināciju parāda, ka vecums vai mītnes valsts to būtiski neietekmē. Vienlaikus darba algas diskriminācijas varbūtība palielinās noteiktās nozarēs strādājošām Latvijas emigrantēm ar augstāko izglītību. Kontrolējot citus mainīgos, redzams, ka augsti izglītotas sievietes, kas strādā informācijas un komunikācijas pakalpojumu nozarēe, ar lielāku varbūtību ir pieredzējušas uztverto darba algu diskrimināciju. Varbūtība sastapties ar situāciju, kad par līdzīgu darbu saṇem mazāku atalgojumu nekā vietējie iedzīvotāji, pieaug arī tām sievietēm, kas strādā rūpniecības un enerǵētikas nozarē, veselības un sociālās aprūpes nozarē, kā arī emigrantēm, kas strādā tirdzniecības, ēdināšanas un izmitināšanas pakalpojumu jomā.

\section{UZTVERTĀ DISKRIMINĀCIJA DARBĀ, EKONOMISKĀ INTEGRĀCIJA UN PROFESIONĀLĀ IZGLITTIIBA}

Regresijas modelis attiecībā uz uztverto darba uzdevumu diskrimināciju parāda, ka Latvijas emigrantes, kam ir grūtības “savilkt galus” un nomaksāt nepieciešamos izdevumus mītnes valstī, ar lielāku varbūtību izjūt, ka viṇām biežāk nekā vietējiem uzdod neizdevīgus un/vai nepatīkamus darbus. Līdzīgi ar uztverto darba uzdevumu diskrimināciju lielāka varbūtība ir saskarties sievietēm, kam ir bijušas grūtības “savilkt galus” Latvijā pirms aizbraukšanas.

Kontrolējot citus mainīgos, ietekme uz uztverto darba uzdevumu diskrimināciju vērojama saistībā ar to, vai ir vai nav noslēgts rakstisks darba līgums 
ar darba devēju. Tām Latvijas emigrantēm, kam ir rakstisks darba līgums ar darba devēju, ir mazāka varbūtība izjust ar darba uzdevumiem saistītu diskrimināciju. Tas saskan ar citos pētījumos novēroto, ka darba n̦ēmējiem, kam ir rakstisks līgums ar darba devēju, ir lielākas sociālās garantijas un viṇi vairāk paḷaujas uz darba attiecību likumību (Halaby, 1986). Padziļināti aplūkojot, kas ir tās augsti izglītotās Latvijas emigrantes, kam nav rakstiska darba līguma, atklājas, ka, pirmkārt, tās biežāk ir pašnodarbinātās un uzṇēmējas, kā arī sievietes, kas strādā ğimenes biznesā. Šī grupa veido apmēram vienu trešdaḷu no Latvijas emigrantēm, kam nav rakstiska darba līguma. Otrkārt, sievietes, kas strādā rūpniecībā, būvniecībā, lauksaimniecībā, kā arī informācijas un komunikācijas pakalpojumu nozarē, biežāk saskaras ar situāciju, ka viṇām nav rakstiska līguma. Divas trešdaḷas jeb 64\% no tām Latvijas emigrantēm, kas strādā bez rakstiska darba līguma, neizmanto savu kvalifikāciju vai izglītību pašreizējā pamatdarbā.

Cita hipotēze, kas pārbaudīta analīzes rezultātā, attiecas uz kvalifikācijas vai izglìtības izmantošanu pašreizējā pamatdarbā, kā arī grūtībām Latvijā iegūto izglītību vai profesionālo kvalifikāciju atzīt mītnes zemē. Kontrolējot citus mainīgos, redzams, ka Latvijas emigrantēm, kas lielā mērā izmanto savu kvalifikāciju vai izglītîbu pašreizējā pamatdarbā, ir mazāka varbūtība saskarties ar to, ka viṇām biežāk nekā vietējiem uzdod neizdevīgus vai nepatīkamus darbus. Savukārt tās Latvijas emigrantes, kas ir saskārušās ar grūtībām, ka Latvijā iegūtā izglītība vai profesionālā kvalifikācija netiek atzīta mītnes zemē, ar lielāku varbūtību ir izjutušas darba uzdevumu diskrimināciju. Šāda varbūtība pieaug arī to Latvijas emigranšu vidū, kas ārpus Latvijas ir pabeigušas profesionālās pilnveides kursus.

Līdzīgas tendences vērojamas arī attiecībā uz uztverto algu diskrimināciju, kad Latvijas emigrantes par līdzīgu darbu saṇem mazāku atalgojumu nekā vietējie iedz̄ivotāji. Kontrolējot citus mainīgos, sievietēm, kam ir grūtības "savilkt galus” un nomaksāt nepieciešamos izdevumus mītnes valstī, kā arī sievietēm, kam bijušas grūtības “savilkt galus” Latvijā pirms aizbraukšanas, ir lielāka varbūtība saskarties ar uztverto algu diskrimināciju. Savukārt tām emigrantēm, kam ir rakstisks līgums ar darba devēju un kas darbā lielā mērā izmanto iegūto kvalifikāciju vai izglītību, ir mazāka varbūtība izjust algu diskrimināciju. Tām, kas ir saskārušās ar grūtībām, ka Latvijā iegūtā izglītība vai profesionālā kvalifikācija netiek atzīta mītnes zemē, un kas ārpus Latvijas ir pabeigušas profesionālās pilnveides kursus, atkal ir lielāka varbūtība izjust algu diskrimināciju.

Interesanti, ka uztvertā diskriminācija attiecībā uz atvaḷinājumiem lielākoties nav saistīta ar iepriekš aplūkotajiem mainīgajiem, izņemot divus. 
Varbūtība, ka vienmēr jāiet atval̦inājumā "sliktajā” gadalaikā, paaugstinās tikai tajos gadījumos, kad Latvijā iegūtā izglītība vai profesionālā kvalifikācija mītnes zemē netiek atzīta, kā arī situācijās, kad emigrantes ārpus Latvijas ir pabeigušas profesionālās pilnveides kursus.

Attiecībā uz atgriešanās plāniem tuvākajos piecos gados redzams, ka tām Latvijas emigrantēm, kas tuvāko piecu gadu laikā plāno atgriezties Latvijā, ir lielāka varbūtība izjust algu diskrimināciju. Tas liecina, ka atgriešanās plāniem tuvākajos piecos gados ir zināma korelācija ar uztverto diskrimināciju, un neapmierinātība ar savu situāciju mītnes valstī var būt viens no skaidrojumiem, kādēḷ emigrantes atgriežas Latvijā.

\section{UZTVERTĀ DISKRIMINĀCIJA DARBĀ UN PIEDERİBAS SAJŪTA}

MITTNES ZEMEI UN LATVIJAI

Faktoru analīzes rezultātā iegūtais faktors par piederības sajūtu mītnes zemei regresijas analīzē apstiprina sākotnēji izvirzîto hipotēzi, ka tās Latvijas emigrantes, kas ciešāk jūtas piederīgas mītnes valstij, ar mazāku varbūtību saskarsies ar uztverto diskrimināciju. Regresijas analīze liecina, ka tām Latvijas emigrantēm, kas ciešāk jūtas piederīgas mītnes valstij, ir mazāka varbūtība izjust uztverto diskrimināciju attiecībā uz darba uzdevumiem. Arī uztvertās algas diskriminācijas varbūtība samazinās, ja emigrante izjūt spēcīgu piederību mītnes valstij. Savukārt tās Latvijas emigrantes, kas jūtas mazāk piederīgas mītnes valstij, ar lielāku varbūtību piedzīvo situāciju, ka viṇām biežāk nekā vietējiem tiek uzdoti neizdevīgi vai nepatîkami darbi, kā arī to, ka par līdzīgu darbu saņem mazāku atalgojumu nekā vietējie iedzīvotāji. Vienlaikus piederības sajūta mītnes valstij neietekmē uztverto diskrimināciju saistībā ar neizdevīgu atvaḷinājuma laiku. Pretēji gaidītajam, piederības sajūta Latvijai nekādā veidā būtiski neietekmē dažādus uztvertās diskriminācijas veidus.

\section{SECINĀJUMI}

Šīs nodaḷas uzdevums bija raksturot augsti izglītotu sieviešu situāciju darba tirgū emigrācijā un izzināt, kādi faktori ietekmē diskriminācijas uztveri viṇu vidū. Izpētes galvenais sociālais fenomens ir uztvertā darba diskriminācija, konkrēti, trīs tās formas: uztvertā darba uzdevumu diskriminācija, uztvertā atvaḷinājumu diskriminācija un uztvertā darba algas diskriminācija. Izpētes mērkgrupa ir augsti izglītotas Latvijas sievietes emigrācijā, jo šī grupa līdz šim ir mazāk pētīta. 
Binārās log̣istiskās regresijas analīze kopumā dod iespēju izdarīt šādus galvenos secinājumus. Pirmkārt, analizējot trīs dažādus uztvertās darba diskriminācijas veidus, atklājas, ka uztvertā diskriminācija ir komplekss fenomens un to nebūtu pareizi mērīt un analizēt, izmantojot tikai vienu summāro diskriminācijas indikatoru. Trīs dažādo uztvertās diskriminācijas formu varbūtību (uztvertā darba uzdevumu diskriminācija, uztvertā atvaḷinājumu diskriminācija un uztvertā darba algas diskriminācija) ietekmē atšḳirīgi faktori.

Otrkārt, pētījuma rezultāti apstiprina izvirzīto asimilācijas hipotēzi: jo ciešāk Latvijas emigrantes jūtas piederīgas mītnes valstij, jo mazāk tās uztver diskrimināciju. Divi no trīs binārās loǵistiskās regresijas analīzes modeḷiem parāda: jo mazāk emigrantes jūtas piederīgas mītnes valstij, jo lielāka varbūtība, ka tās izjūt diskrimināciju, konkrēti, viņām ir lielāka varbūtība saskarties ar situāciju, kad viṇām biežāk nekā vietējiem uzdod neizdevīgus vai nepatīkamus darbus (uztvertā darba uzdevumu diskriminācija), un arī situāciju, kad par līdzīgu darbu viṇas saṇem mazāku atalgojumu nekā vietējie iedzīvotāji (uztvertā algu diskriminācija). Vienlaikus piederības sajūta Latvijai neietekmē diskriminācijas uztveri. Transnacionālisma teoriju kontekstā tas netieši apliecina, ka piederības sajūta mītnes zemei un piederības sajūta izcelsmes valstij ir divi dažādi fenomeni, kas nav viens ar otru saistīti (Levitt \& Glick Schiller, 2004; Haas \& Fokkema, 2011; Waldinger, 2017). Spēcīga piederības izjūta mītnes valstij neizslēdz iespēju saglabāt arī spēcīgu piederības sajūtu savai izcelsmes valstij.

Treškārt, sava finanšu stāvokḷa novērtējums gan pirms, gan pēc emigrācijas ir saistîts ar uztverto diskrimināciju darbavietā. Tomēr jānorāda, ka pētījuma rezultāti uzrāda atšķirīgu situāciju saistībā ar dažādiem uztvertās darba diskriminācijas veidiem. Augsti izglītotām emigrantēm, kam ir grūtības "savilkt galus” un nomaksāt nepieciešamos izdevumus mītnes valstī, ir lielāka varbūtība saskarties ar darba uzdevumu diskrimināciju, kad viṇām biežāk nekā vietējiem uzdod neizdevīgus vai nepatīkamus darbus, kā arī ar darba algas diskrimināciju. Vienlaikus šajā grupā ir mazāka varbūtība saskarties ar atvalinājumu diskrimināciju, kad jāiet atvaḷinājumā "sliktajā” gadalaikā. Tām emigrantēm, kam bija grūtības "savilkt galus” un nomaksāt nepieciešamos izdevumus Latvijā, arī ir lielāka varbūtība saskarties ar darba uzdevumu diskrimināciju un darba algas diskrimināciju.

Ceturtkārt, rakstiska darba līguma neesamība būtiski palielina uztvertās diskriminācijas varbūtību. Sievietēm, kam ir rakstisks darba līgums, ir mazāka varbūtība saskarties ar darba uzdevumu diskrimināciju un darba algas diskrimināciju. 
Piektkārt, grūtības ar Latvijā iegūtās izglītîbas vai profesionālās kvalifikācijas atzišanu būtiski ietekmē uztverto diskrimināciju. Tas attiecas uz visiem trijiem padziḷināti aplūkotajiem uztvertās diskriminācijas veidiem. Tātad Latvijas emigrantēm, kas ir saskārušās ar grūtībām, ka Latvijā iegūtā izglītība vai profesionālā kvalifikācija netiek atzīta mītnes zemē, ir lielāka varbūtība izjust darba diskrimināciju vai netaisnīgu attieksmi. Savukārt tām Latvijas emigrantēm, kas darbā lielā mērā izmanto savu izglîtību vai kvalifikāciju, ir mazāka varbūtība saskarties ar darba uzdevumu diskrimināciju un darba algas diskrimināciju.

Sestkārt, tādi faktori kā vecums un mītnes valsts būtiski neietekmē uztvertās diskriminācijas varbūtību, bet ir vērojama ietekme saistībā ar nodarbinātības jomu. Īpaša nozīme nodarbinātības jomai ir attiecībā uz uztverto darba algas diskrimināciju. Augsti izglītotas sievietes, kas strādā informācijas un komunikācijas pakalpojumu nozarē, rūpniecības un enerǵētikas nozarē, veselības un sociālās aprūpes nozarē, kā arī emigrantes, kas strādā tirdzniecības, ēdināšanas un izmitināšanas pakalpojumu jomā, ar lielāku varbūtību ir pieredzējušas situāciju, kad par līdzīgu darbu saṇem mazāku atalgojumu nekā vietējie iedzīvotāji.

Aplūkotie pētījuma rezultāti ir nozīmīgi antidiskriminācijas politikas kontekstā, kas tiek īstenota gan nacionālā līmenī konkrētās valstīs, gan konkrētu uzṇēmumu līmen̄i. Jāatzīmē, ka lielākoties OECD valstīs atbilstoši konkrētās valsts antidiskriminācijas politikas likumiem uzṇēmēji savos uzṇēmumos īsteno prakses, lai mazinātu diskrimināciju pēc rases, ādas krāsas, etniskās piederības, dzimuma, vecuma, seksuālās orientācijas un citiem kritērijiem, kas noteikti ar likumu. Tomēr formālas antidiskriminācijas prasības ne vienmēr praksē tiek īstenotas. Kā norādījis Pīters H. Šaks (Peter H. Schuck) (2000), rakstītais likums ("likums grāmatās”) nav gluži tas pats, kas "likums darbībā" vai “likums cilvēku apziṇā”. Tādēḷ nepietiek tikai ar antidiskriminācijas likumu vai antidiskriminācijas vadlīnijām uzṇēmumā. Ir svarīgi, lai darbinieki, kam ir jautājumi vai aizdomas par jebkāda veida diskrimināciju, tiek mudināti apspriest šos jautājumus ar uzṇēmuma vadību vai sniegt anonīmu informāciju, ja ir bažas par negatīvām sekām. İpaša uzmanība būtu jāpievērš izglītošanai par antidiskrimināciju, lai sekmētu to, ka darbinieki darbavietā spēj atpazīt diskriminējošas prakses un nebaidās ziṇot par to. Tātad ir jāturpina izplatīt informācija par iespējām ziṇot par diskrimināciju vai pat jārada īpašas anonīmas ziṇošanas iespējas.

Pētījuma rezultāti atkārtoti norāda uz nepieciešamību slēgt rakstisku darba līgumu ar darba devēju, lai stiprinātu migrantu pārliecību par darba attiecību 
legalitāti un savu tiesību aizstāvēšanas iespējām. Ir jāturpina intervēt darba ṇēmēji par nepieciešamību parakstīt darba līgumu, jo tas l̦auj gan izvairīties no pārpratumiem, gan arī aizsargā abas līgumslēdzējpuses. Ir nepieciešama arī informācija, kur vērsties, ja darba devējs nevēlas slēgt darba līgumu.

Vēl viena problēma, kas nav līdz galam atrisināta Latvijas migrantu gadījumā, ir grūtības ar Latvijā iegūtās izglìtības vai profesionālās kvalifikācijas atzišanu, kas arī būtiski ietekmē uztverto diskrimināciju. Lai gan šī problēma attiecas tikai uz regulētām profesijām, piemēram, veselības aprūpes darbiniekiem vai advokātiem, pētījums atklāj, ka tā ir nozīmīga problēma antidiskriminācijas politiku kontekstā. Atsevišḳos gadījumos viens no iespējamiem risinājumiem varētu būt divpusējie starpvalstu līgumi starp uzṇemošajām un nosūtošajām valstīm - tas varētu sekmēt izglītības sertifikātu atzišanu un mazinātu "smadzeṇu izniekošanu" un diskrimināciju darba tirgū.

N̦emot vērā to, ka strādāšana noteiktās nozarēs būtiski palielina uztvertās diskriminācijas varbūtību augsti izglītoto Latvijas emigrantu vidū, īpaša uzmanība būtu jāpievērš antidiskriminācijas politikām un vadlīnijām šādās nozarēs: informācijas un komunikācijas pakalpojumi, rūpniecība un enerǵêtika, veselība un sociālā aprūpe, tirdzniecības, ēdināšanas un izmitināšanas pakalpojumi, jo tieši šajās nozarēs Latvijas emigrantes par līdzīgu darbu saṇem mazāku atalgojumu nekā vietējie iedzīvotāji.

Nodaḷas noslēgumā izvērtējot veiktās analīzes ierobežojumus, jāatzīmēe kauzalitātes problēma. Piemēram, analīzes rezultāti parāda, ka tās Latvijas emigrantes, kas jūtas mazāk piederīgas mītnes valstij, ar lielāku varbūtību saskarsies ar uztverto diskrimināciju, un tas ḷauj secināt, ka piederības sajūta mītnes valstij ietekmē uztverto diskrimināciju. Tomēr, iespējams, kauzālās attiecības ir tieši pretējas, un tas, ka emigrante ar augstāko izglītību izjūt diskrimināciju, mazina viṇas piederības sajūtu uzṇemošajai valstij. Līdzīgs piemērs attiecas uz plāniem atgriezties Latvijā un uztverto diskrimināciju. Saskaṇā ar analīzes rezultātiem tām emigrantēm, kas tuvāko piecu gadu laikā plāno atgriezties Latvijā, ir lielāka varbūtība saskarties ar uztverto algas diskrimināciju. Iespējams, precīzāk situāciju raksturo apgrieztas kauzālās attiecības, un tās emigrantes, kas ir saskārušās ar to, ka par līdzīgu darbu saṇem mazāku atalgojumu nekā vietējie iedzīvotāji, ar lielāku varbūtību apsver atgriešanos Latvijā. Šo iemeslu dēḷ jebkādi vispārinājumi par analīzes rezultātiem ir jāizdara ḷoti piesardzīgi, un secinājumu validēšanai nepieciešami turpmāki pētījumi. 


\section{PIESAISTIIŠANAI LATVIJAI}

Pētnieciskajā literatūrā ir identificēti dažādi remigrācijas politikas virzieni, un šajā remigrācijas politikas analīzē izmantots Deivida Makenzija (David McKenzie) un Dīna Janga (Dean Yang) piedāvātais dalījums (McKenzie \& Yang, 2014). Saskaṇā ar viṇu pieeju remigrācijas politikā var izšḳirt trīs veidu pasākumus: (1) mazināt dažādus šḳēršḷus, kas traucē atgriezties (birokrātisko procedūru mazināšana, informācijas nodrošināšana); (2) atbalstīt tās grupas, kas citādi varbūt neatgrieztos (finansiāla un cita veida atbalsta pasākumi); (3) īstenot reintegrācijas atbalsta pasākumus.

D. Makenzija un D. Janga remigrācijas politikas pasākumu dalījums ir papildināts, pievienojot pasākumus, kas veltīti sadarbībai ar diasporu, jo daudzās valstīs, tajā skaitā Latvijā, remigrācijas politika ir integrēta ar politiku, kas vērsta uz sadarbību ar diasporu (Kḷave \& Šūpule, 2015, 2019). Diasporas politikas klasifikācijai izmantoti Alana Gemlena (Alan Gamlen) (2006) identificētie trīs diasporas iesaistes politikas tipi. Saskaṇā ar A. Gemlenu pirmais posms diasporas politikas veidošanā ir kapacitātes veidošana, kam seko 
diasporas tiesību paplašināšana un diasporas pienākumu veidošana. Kapacitātes veidošanas politika paredz veidot komunikāciju ar diasporu, kas balstās uz vienotas nācijas ideju un vienotu simbolu un zīmju izplatīšanu, piemēram, valsts svētku svinēšanu diasporā, valsts valodas mācīšanu diasporas pārstāvjiem, nacionālās kultūras pasākumus u. tml. Kapacitātes veidošanas politikas uzdevums ir radīt institūcijas, institucionālas struktūras, kas nodrošina komunikāciju ar diasporu. Sadarbības veidošanai tiek organizēti dažādi diasporas forumi vai konferences, un visu šo aktivitāšu mērḳis ir veicināt emigrantu un viṇu pēcteču piederības sajūtu diasporai. Diasporas tiesību paplašināšanas politika attiecas gan uz vēlēšanu tiesību paplašināšanu, iekḷaujot tajā diasporas pārstāvjus, gan arī uz emigrantu tiesību aizsardzību ārzemēs. Diasporas pienākumu veidošanas politika parasti ir vērsta uz ekonomiskās sadarbības stiprināšanu, lai izcelsmes valsts gūtu jaunas investīcijas vai citu kapitālu, ko piesaista diasporas pārstāvji. Tā ir arī nodokḷu iekasēšana no emigrantiem, un diasporai var būt liela nozīme politiskā lobija īstenošanā mītnes valstī. Lai piesaistītu diasporas sekmīgāko uzṇēmēju, zinātnieku vai augsti kvalificētu speciālistu zināšanas vai kapitālu izcelsmes valstij, tiek veidotas speciālas interneta platformas un dažādos veidos veicināta šo grupu tīklošanās.

No metodologiiskā viedokḷa konkrēto analīzi ierobežo t. s. metodoloğiskais nacionālisms, kas definēts kā "pien̦ēmums, ka nācija/valsts/sabiedrība ir mūsdienu pasaules dabiskās sociālās un politiskās formas” (Wimmer \& Glick-Schiller, 2002: 302; Pries, 2016). N̦emot vērā to, ka pētījuma mērḳis ir izvērtēt, kādas remigrācijas politikas būtu piemērotas Latvijai, migrācijas procesi aplūkoti no nācijas valsts perspektīvas. Arī citi pētnieki atzīst, ka, neskatoties uz diskusijām par transnacionālismu, nācijas valstu perspektīva diasporas pētniecībā ir loğiska un saglabā vadošās pozīcijas (Chernilo, 2011; Bharte \& Sharma, 2014).

Migrācijas procesu un ekonomiskās attīstības diskusiju kontekstā H. de Hāss nošķir “migrācijas optimistus” un "migrācijas pesimistus” jeb, citiem vārdiem, divus plašāk izplatītos ideoloǵiskos diskursus, kuros migrācija tiek aplūkota (Hass, 2010). Optimisti savā pieejā uzsver migrācijas iespējamos ieguvumus, tai skaitā "smadzeņu ieguvumus", taču pesimisti vairāk saskata ar migrāciju saistītos zaudējumus, nevienlīdzību un "smadzeņu aizplūšanu”. Sociālās teorijas kontekstā migrācijas optimisti ir vairāk saistîti ar funkcionālisma teorētisko pieeju, bet pesimisti - ar strukturālismu. Saskaṇā ar de Hāsa analīzi vērojama nemitīga svārstīga kustība: 20. gadsimta 60. gados migrācijas debatēs valdīja optimisms, 80. gados to nomainīja migrācijas pesimisms un imigrācijas likumu stingrība, bet pēc 2000. gada atkal kopumā vērojams 
migrācijas optimisms un uzsvars uz visu pušu ieguvumiem no migrācijas (angl. - win-win-win / triple win). Autore pieņem, ka migrācijas ieguvumi/ zaudējumi un "smadzeņu aizplūde” vai “smadzeṇu cirkulācija” ir ḷoti atkarīga no konkrētā konteksta un analīzes perspektīvas. Analizējot migrācijas procesus konkrētas izcelsmes valsts (Latvijas) kontekstā, vairāk iezīmējas negatīvie migrācijas aspekti. Aplūkojot migrācijas procesus plašāka reǵiona (Eiropas) attīstības kontekstā, secinājumi, iespējams, var būt atšḳirīgi, jo augsti kvalificētu speciālistu migrācija uz reǵiona attīstības centriem ir viens no faktoriem, kas var sekmēt reǵiona attīstību.

Remigrācijas politikas ārvalstu pieredzes izvērtējumā ir iekḷautas gan Eiropas valstu, gan arī Ķ̄̄nas, Indijas, Austrālijas un citu valstu pieredzes. Galvenā uzmanība pievērsta iniciatīvām, kas izstrādātas no izcelsmes valsts perspektīvas, jo pastāv daudzas iniciatīvas, ko uzsākušas uzṇemošās valstis, lai veicinātu migrantu atgriešanos izcelsmes valstīs, bet tās biežāk attiecas uz trešo valstu valstspiederīgajiem.

Šajā nodạ̣ā lielākoties analizēta angḷu valodā pieejamā literatūra par remigrācijas un diasporas politiku. Tie aptver laika posmu no 1991. gada, tomēr galvenā vērība pievērsta avotiem, kas attiecas uz periodu pēc 2000. gada. Ir aplūkots arī remigrācijas politikas veidošanās process Latvijā, Reemigrācijas atbalsta pasākumu plāns 2013.-2016. gadam un tajā ietverto pasākumu turpināšana pēc 2016. gada, kā arī jaunās iniciatīvas. Nodaḷas secinājumos izvērtētas iespējas ārvalstu pieredzi izmantot Latvijā.

\section{1. ĀRVALSTU PRAKSE}

Dažādos avotos norādīts, ka arvien vairāk valstu pievērš uzmanību remigrācijas veicināšanai un sadarbībai ar diasporu (Gamlen, 2006; Hooper \& Sumption, 2016; McKenzie \& Yang, 2014). Augsti kvalificētu speciālistu remigrācija pēdējo 20 gadu laikā ir būtiski ietekmējusi tādu valstu kā Ķīna, Taivāna un Indija attīstību (Sills, 2008). Vienlaikus jāuzsver, ka ne visas remigrācijas programmas, kas vērstas uz tautiešu atgriešanos, ir sekmīgas, piemēram, Japānā pēc remigrācijas politikas rezultātu izvērtēšanas šāda programma ir slēgta (Tsuda, 2010).

Remigrācijas un diasporas politiku izveide ir cieši saistīta ar noteiktiem migrācijas procesiem konkrētā regiionā. Pēc režīmu maiṇas 1989.-1990. gadā un Eiropas Savienības paplašināšanās 2004. un 2007. gadā Eiropā migrācijas procesi būtiski mainījās. Brīvas pārvietošanās iespēju uzlabošanās sekmēja 
to, ka cilvēki no mazāk attīstītiem reǵioniem pārvietojās un joprojām turpina pārvietoties uz attīstītākiem reǵioniem Eiropā. İpaši raksturīgi, ka aktīvāk pārvietojas jauni un izglītoti cilvēki (Boros \& Hegedüs, 2016). Līdz ar to daudzas jaunās ES dalībvalstis saskaras ar depopulācijas un "smadzen̨u aizplūšanas” problēmu (Hazans, 2015; Kaczmarczyk \& Lesińska, 2013), kas veicina remigrācijas politikas aktualizāciju šajās valstīs.

Politikas līmenī aizvien vairāk valstu atzīst, ka nozīmīga ir ne tikai fiziskas atgriešanās veicināšana, bet arī ciešāku sadarbības saišu veidošana ar diasporu (Meyer, 2001; Haas, 2006; Merz, Chen, \& Geithner, 2009; Tejada \& Bhattacharya, 2014). Vienlaikus daudzas valstis saskaras ar grūtībām politikas formulēšanā, jo ir nepieciešams uzrunāt gan augsti kvalificētus, gan arī mazkvalificētus emigrantus, bet diasporas organizāciju līmenī šīs grupas bieži vien savā starpā nesadarbojas (Khadria, 2014).

Vairākos avotos norādīts, ka tikai atsevišķas izcelsmes valstis veido politiku, kas vērsta uz augsti kvalificētu speciālistu remigrāciju, jo lielākoties izcelsmes valstīs trūkst augsti kvalificētiem speciālistiem piemērotu darbavietu, bet dažās valstīs tiek uzskatīts, ka lielāks ieguvums ir no naudas pārskaitījumiem, tādēḷ remigrācija netiek veicināta (Haas, 2006; Hooper \& Sumption, 2016).

Sociālo zinātṇu literatūrā kopumā ir ievērojami vairāk pētījumu un rakstu par to, kā veicināt augsti kvalificētu speciālistu atgriešanos trešajās valstīs, un salīdzinoši maz pētījumu par atgriešanās veicināšanas politiku ES valstīs. Tomēr jāatzīmē vairāki nozīmīgi pēdējo gadu pētījumi un grāmatas, kur analizēti šie jautājumi.

Grāmatā "Remigrācija un reǵionālā attīstība Eiropā”" (angl. - Return Migration and Regional Development in Europe) norādīts, ka uzṇemošās valstis nepietiekami sadarbojas ar nosūtošajām valstīm (Lang et al., 2016: 18; Boros \& Hegedús, 2016). Tomēr cits autors šajā pašā grāmatā, izvērtējot dažādās politikas, kas plānotas kā trīskārši ieguvumi, nesniedz viennozīmīgus secinājumus (Pries, 2016). Šādas politikas ir iecerētas, pirmkārt, lai sekmētu augsti kvalificēta darbaspēka nodrošinājumu uzṇemošajā valstī; otrkārt, lai paaugstinātu ekonomiskās attīstības iespējas nosūtošajā valstī, kurā atgriežas profesionālis, kas ieguvis starptautisku pieredzi; treškārt, par ieguvēju tiek uzskatīts pats speciālists, kas ieguvis jaunas kvalifikācijas un sadarbības tīklus, kā arī noteiktā periodā guvis lielākus ienākumus. Analizētās politikas vienlaikus lielākoties ir mazskaitlīgas un ne vienmēr tiek līdz galam īstenotas (Pries, 2016: 34).

Arī citi autori, kas optimistiskāk vērtē "smadzeṇu cirkulācijas” iespējas, norāda, ka politikas, kas vērstas uz augsti kvalificētu speciālistu remigrācijas 
veicināšanu, lielākoties ir l̦oti specializētas, mazskaitlīgas, un to efektivitāte ir grūti izvērtējama (Hooper \& Sumption, 2016).

Ludgers Prīss (Ludger Pries), analizējot Vācijas viesstrādnieku politiku, skaidro, kādēl šḳietami pievilcīgās idejas par trīskāršā ieguvuma politiku ne vienmēr ir sekmīgas. Viṇa skaidrojuma pamatā ir tas, ka, pirmkārt, netiek ñemtas vērā visu iesaistīto partneru kompleksās attiecības un dažādās situācijas, un, otrkārt, darba migrācija ir saistīta ar ilgāku laika posmu (gadu un vairāk), un šajā laikā mainās iesaistīto partneru un arī paša migranta mērḳi, stratēóijas un uzvedība (Pries, 2016: 37). L. Prīss secina: jo īsāks ir cirkulārās darba migrācijas periods (uzturēšanās uzṇemošajā valstī), jo grūtāk migrantam un darba devējam gūt labumu no šīs migrācijas, jo sekmīgai iekḷaušanai darba tirgū ir nepieciešams adaptācijas periods. Savukārt, jo ilgāks ir cirkulārās darba migrācijas periods, jo lielāka iespēja, ka migrācija būs pastāvīga un vairs neatbildīs konkrēetās programmas prasībām.

Būtiski uzsvērt, ka, no valsts perspektīvas raugoties, migrācijas procesi nav pilnībā kontrolējami un paredzami. Migrācijas lēmumus pieṇem indivīds, pamatojoties uz ǵimenes un plašāku ekonomisko un politisko kontekstu gan uzṇemošajā, gan izcelsmes valstī, kā arī pasaulē kopumā. No politikas īstenošanas perspektīvas tas ievērojami apgrūtina migrācijas ietekmes plānošanu un migrācijas politikas veidošanu, jo valstis var saskarties ar situāciju, kad, piemēram, daudzi emigranti ekonomiskās recesijas dēḷ atgriežas izcelsmes valstī, bet konkrētā valsts ne vienmēr tam ir gatava un nespēj atbilstoši reaǵēt (Kaczmarczyk \& Lesińska, 2013).

Kā jau norādīts ievadā, nodạ̣ā par citu valstu labajām praksēm, veicinot augsti kvalificētu speciālistu atgriešanos, uzmanība pievērsta gan politikām, kas tiešā veidā sekmē fizisku augsti kvalificētu speciālistu atgriešanos izcelsmes valstī (remigrācijas politika), gan arī tām politikām, kas sekmē sadarbību un "smadzeṇu apmaiṇu” jeb, citiem vārdiem, zināšanu apmaiṇu un pienesumu izcelsmes valsts ekonomikai (sadarbības ar diasporu politika). Turpinājumā ir sniegts apkopojums par literatūrā biežāk aprakstītajām ārvalstu remigrācijas politikām.

\section{REMIGRĀCIJAS POLITIKA}

Atsaucoties uz D. Makenzija un D. Janga remigrācijas politikas tipoloǵiju (McKenzie \& Yang, 2014), augsti kvalificētu speciālistu atgriešanās veicināšanas instrumenti ir pieskaitāmi pie tiem pasākumiem, kas sniedz atbalstu diasporas grupām, kuras citādi varbūt neatgrieztos (finansiāla un cita veida atbalsta pasākumi). Atbalsts atgriezties tām grupām, kas citādi varbūt 
neatgrieztos, visbiežāk ir vērsts uz šādām trīs grupām: jaunajiem profesionāl̦iem (studentiem, kas ieguvuši augstāko izglîtību ārzemēs), zinātniekiem un diasporas uzṇēmējiem (Šūpule et al., 2016).

Pēdējo 10 gadu laikā viens no visietekmīgākajiem izpētes projektiem par atgriešanās migrāciju Eiropā ir Re-Turn projekts, kurā iesaistīti septiņu Eiropas valstu pētnieki (Vācija, Austrija, Itālija, Polija, Čehija, Ungārija un Slovēnija). Re-Turn projekta pētnieki apkopoja 22 reǵionālas un lokālās remigrācijas veicināšanas iniciatīvas konkrētajās valstīs un izvērtēja kopumā 13 valstu atgriešanās politikas (Kovács et al., 2013).

Balstoties uz Re-Turn projekta pētījumu, 6.1. tabulā ir apkopotas tās remigrācijas politikas iniciatīvas, kuras attiecas uz augsti kvalificētu speciālistu remigrācijas veicināšanu un ir izvērtējamas arī Latvijas kontekstā. Atlases kritēriji ir: (1) iespējamība pārṇemt (reğions, apjoms); (2) darbības virziens: praktisks, ne tikai informatīvs vai simbolisks atbalsts augsti kvalificētiem remigrantiem; (3) iniciatīvas ir vērstas uz ekonomiskās attīstības veicināšanu.

Kopumā Re-Turn projekta pētījums l̦auj secināt: lai piesaistītu un noturētu remigrantus, dažādas iniciatīvas paredz plašu pasākumu klāstu, no kuriem būtiskākie ir darbavietu radīšanas veicināšana, apdzīvotās vietas (valsts, pilsētas, reǵiona) mārketings, stipendijas un granti un finansiālais atbalsts remigrantiem. Visbiežāk uzmanība pievērsta jaunu speciālistu rekrutēšanai. Lielākā daḷa šo politiku ir vērstas uz augsti kvalificētu speciālistu - universitātes līmeña pasniedzēju un pētnieku - remigrācijas veicināšanu, bet atsevišķas politikas pievēršas arī citu profesionāḷu remigrācijas veicināšanai. Jānorāda, ka visas aplūkotās politikas ir uzsāktas pēc 2000. gada, un lielākajā daḷā gadījumu ir sarežğîti vai neiespējami izvērtēt to efektivitāti.

Remigrācijas politiku analīzē var izšḳirt gan tādas aktivitātes, kas vērstas uz augsti kvalificētu speciālistu ilglaicīgas atgriešanās sekmēšanu, piemēram, mācību maksas kredītu apmaksa, slēdzot ilgtermiṇa darba līgumu, gan arī aktivitātes, kas vērstas uz augsti kvalificētu speciālistu īslaicīgas atgriešanās sekmēšanu. Piemēram, nozarēs, kur trūkst augsta līmeṇa speciālistu un nepieciešama speciālista klātbūtne konkrētu uzdevumu risināšanā, tiek izmantota iespēja sekmēt augsti kvalificētu speciālistu (no diasporas ekspertu vidus) īslaicīgu atgriešanos, apmaksājot viṇiem ceḷa izdevumus un konsultācijas (Newland \& Plaza, 2013).

Ilglaicīgas atgriešanās sekmēšana biežāk attiecināma uz tādām mērḳgrupām kā augstskolu mācībspēki un uzṇēmēji. Pasaulē zināmākās ir Taivānas, Ḳinas un Argentīnas īstenotās programmas, lai piesaistītu augstskolu mācībspēkus. Piemēram, Argentīnas zinātnieku un pētnieku diasporas sadarbības 
6.1. tabula. Eiropas valstu pieredze augsti kvalificētu speciālistu remigrācijas veicināšanā

\begin{tabular}{|c|c|c|c|}
\hline $\begin{array}{l}\text { Programmas/ } \\
\text { iniciatīvas } \\
\text { nosaukums }\end{array}$ & $\begin{array}{l}\text { lesaistītā valsts } \\
\text { vai valstis }\end{array}$ & $\begin{array}{l}\text { Laika } \\
\text { posms }\end{array}$ & Apraksts \\
\hline $\begin{array}{l}\text { "Smadzeṇu ieguve": } \\
\text { diasporas iesaistīšana } \\
\text { Albānijas attīstībā }\end{array}$ & Albānija & 2006-2011 & $\begin{array}{l}20 \text { albāṇu mācībspēki no ārvalstīm piesaistīti } \\
\text { Albānijas universitātēm }\end{array}$ \\
\hline $\begin{array}{l}\text { HOMING PLUS } \\
\text { programma }\end{array}$ & Polija & $2010-$ & $\begin{array}{l}\text { Doktora grādu ieguvušo jauno poḷu pētnieku } \\
\text { remigrācijas veicināšanas programma. Izsniegti } \\
\text { pētniecības granti un pētniecības stipendijas }\end{array}$ \\
\hline $\begin{array}{l}\text { Lendület (Momentum) } \\
\text { programma }\end{array}$ & Ungārija & $2009-2017$ & $\begin{array}{l}\text { Atbalsta programma jaunajiem, īpaši talantīgajiem } \\
\text { pētniekiem, kuri dzīvo gan ārvalstīs, gan Ungārijā }\end{array}$ \\
\hline $\begin{array}{l}\text { lespēju radīšana } \\
\text { Gruzijas } \\
\text { remigrantiem }\end{array}$ & Gruzija, Čehija & $2003-$ & $\begin{array}{l}\text { Konsultācijas darba atrašanā Gruzijā, atbalsta } \\
\text { sniegšana remigrantiem, kuri pārceḷas no Čehijas uz } \\
\text { Gruziju. Sekmīgi uz dzīvi pārcēlušies } 160 \text { remigranti }\end{array}$ \\
\hline $\begin{array}{l}\text { powroty.gov.pl } \\
\text { programma }\end{array}$ & Polija & $2008-$ & $\begin{array}{l}\text { Interneta portāls, kurā apkopota informācija par } \\
\text { atgriešanos Polijā, kā arī tiek sniegtas konsultācijas }\end{array}$ \\
\hline $\begin{array}{l}\text { Slovensko Calling } \\
\text { ("Slovākija sauc") }\end{array}$ & Slovākija & 2009 & $\begin{array}{l}\text { Interneta portāls, kurā apkopota informācija par } \\
\text { atgriešanos Slovākijā, kā arī tiek sniegtas konsultācijas }\end{array}$ \\
\hline $\begin{array}{l}\text { Solidaritātes tīkls. } \\
\text { Ukraina }\end{array}$ & Ukraina, Austrija & $2008-2009$ & $\begin{array}{l}\text { Materiālais atbalsts remigrantiem, kuri pārceḷas no } \\
\text { Austrijas uz Ukrainu. Sekmīgi pārcēlušies uz dzīvi } \\
163 \text { remigranti }\end{array}$ \\
\hline Apmācības Portugālē & Portugāle & $\begin{array}{l}2000-2003 \\
2005-2006\end{array}$ & $\begin{array}{l}\text { Jauno portugālu izcelsmes profesionālu apmācības } \\
\text { un reintegrācija Portugālē. Sekmīgi uz dzīvi } \\
\text { pārcēlušies } 366 \text { remigranti }\end{array}$ \\
\hline $\begin{array}{l}\text { Turcijas nacionālā } \\
\text { nanotehnoloǵiju } \\
\text { pētniecības centra } \\
\text { izveide }\end{array}$ & Turcija & 2007- & $\begin{array}{l}\text { Turcijas nacionālā nanotehnoloǵiju pētniecības centra } \\
\text { izveide, apvienojoties vairākām Turcijas universitātēm, } \\
\text { ir vērsta uz to, lai, konsolidējot kompetences un } \\
\text { piesaistot turku izcelsmes speciālistus, veidotu } \\
\text { konkurētspējīgu izpētes centru. Tajā strādā } 25 \\
\text { zinātnieki un } 40 \text { studenti - asistenti, no kuriem vairāk } \\
\text { nekā puse ir remigranti }\end{array}$ \\
\hline
\end{tabular}

Avots: autores kompilācija, balstoties uz Re-Turn projekta veikto izpēti (Kovács et al., 2013). 
tîkls laikā no 2009. līdz 2014. gadam sniedzis atbalstu, lai vairāk nekā 1000 zinātnieku varētu atgriezties Argentīnā (Hooper \& Sumption, 2016: 19).

Atbalsts uzṇēmējdarbībai saistībā ar zināšanu pārnesi augsto tehnoloǵiju jomā tiek nodrošināts Taivānā un Ķīnā. Piemēram, tiek piedāvātas tehnoloǵiju centru, zinātnes parku vai biznesa inkubatoru iespējas, kas ietver dal̦ēju biroja izmaksu segšanu, subsīdijas un vienkāršotas administratīvās procedūras. Ķīnas zinātnes parks Pekinā (angl. - Zhongguancun Science Park), ko sauc arī par Ķīnas Silīcija ieleju, aktīvi piesaista ḳīniešu izcelsmes speciālistus no visas pasaules, tai skaitā no Kalifornijas Silīcija ielejas, Vašingtonas, Tokijas, Toronto un Londonas. Kopumā kopš 2009. gada augsti kvalificētu remigrantu skaits, kas strādā zinātnes parkā, sasniedz vairāk nekā 15 000, un viṇi ir izveidojuši vairāk nekā 6000 uzṇēmumu (UKSPA, 2018).

Cita Âzijas Silīcija ieleja jeb zinātnes parks atrodas Taivānā, kur līdzīgi kā Ķīnā augsto tehnoloǵiju jomā darbojas daudzi uzṇēmumi, kā arī jaunuzņēmumi (angl. - start-ups), kas piesaista augsti kvalificētus Taivānas izcelsmes speciālistus jau kopš 20. gadsimta 80. gadiem (angl. - Hsinchu Science Park). Taivānas valdība remigrantiem, kas no Silīcija ielejas atgriežas Taivānā, piedāvā finansiālu atbalstu, nodokḷu atvieglojumus, modernu mājokli, kā arī iespējas iegādāties viniem nepieciešamās jaunākās tehnoloğijas, organizēt zinātniskas konferences u. tml. Kopumā šajā zinātnes parkā uzṇēmējdarbību uzsākuši vairāk nekā 4000 augsti kvalificētu remigrējušu taivāniešu (Hsinchu Science Park, 2018).

İslaicīgās atgriešanās sekmēšanas pieeja lielākoties tiek izmantota, veidojot individuālu sadarbību, nevis valsts programmas, jo šādu valsts programmu veidošanai ir grūti izstrādāt universālus nosacījumus, tās arī dažkārt izsauc negatīvu reakciju vietējā sabiedrībā (Newland \& Plaza, 2013).

Cita politisko iniciatīvu grupa ir vērsta uz remigrantu integrāciju darba tirgū, jo izcelsmes valsts darba tirgus piedāvājums dažkārt neatbilst augsti kvalificētā remigranta specializācijai. Šajos gadījumos tiek piedāvāti nodarbinātības veicināšanas pasākumi, piemēram, atbalsts darba meklēšanā vai pārkvalifikācijas iespējas. Šāds piemērs ir Kolumbijas programma "Atgriešanās plāns” vai Meksikas programma "Mēs esam meksikāṇi” (Hooper \& Sumption, 2016). Vienlaikus jāuzsver, ka kopumā dažādu valstu politikās pārkvalifikācijas piedāvājumi biežāk ir vērsti uz mazkvalificēto vai vidēji kvalificēto speciālistu apmācību, jo augsti kvalificēti speciālisti lielākoties paši prot atrast darba piedāvājumus.

Vairākas valstis, lai veicinātu augsti kvalificētu speciālistu atgriešanos, ir izmēğinājušas dažādus nodokḷu atvieglojumus remigrantiem, piemēram, 
Ekvadora, Malaizija (angl. - Returning Expert Program) un Kanāda (Hooper \& Sumption, 2016). Kanāda gan pēc izmēgininājuma perioda tomēr ir atteikusies no nodokḷu atvieglojumiem remigrantiem (Lowell, 2002). Nodokḷu atvieglojumi paredz samazinātu ienākumu nodokli noteiktu periodu pēc atgriešanās, kā arī nodokḷa un muitas nodevu atcelšanu pārceḷoties (lietām, ko n̦em līdzi atgriežoties).

Dažādi atvieglojumi remigrantiem un viņu gímenēm saistīti arī ar pilsonības statusa saglabāšanu vai piešḳiršanu. Piemēram, Malaizija piešḳir pastāvīgā iedzīvotāja statusu augsti kvalificētā speciālista dzīvesbiedram un bērniem (Hooper \& Sumption, 2016). Pētnieciskajā literatūrā viennozīmīgi pozitīvi tiek vērtētas tādas iniciatīvas kā dubultpilsonības iespēju paplašināšana un nodrošinātas iespējas piedalīties parlamenta vēlēšanās attālināti (Pries, 2016; Lowell, 2002).

Arī Latvijas kaimiṇvalstīs ir îstenotas iniciatīvas, kas veicina augsti kvalificētu speciālistu remigrāciju. Viens no augsti kvalificētu speciālistu īslaicīgas atgriešanās sekmēšanas piemēriem ir Igaunijas programma "Talantus atpakal mājās!” (angl. - Talents Back Home!). 2010. gadā Igaunijas Tirdzniecības un rūpniecības kamera uzsāka programmu, kas aicina jaunos speciālistus atgriezties Igaunijā. Šī programma tika finansēta galvenokārt no Eiropas Sociālā fonda līdzekḷiem. Programmas mērḳis bija veicināt, lai studenti, kuri studē universitātēs ārvalstīs vai ir ieguvuši zinātnisko grādu ārvalstu universitātēs, bet ir Igaunijas valstspiederīgie ar ārvalstīs iegūtu profesionālo pieredzi, atgrieztos Igaunijā. Programmas ietvaros dalībniekiem tika piedāvātas nodarbinātības un pašrealizācijas iespējas privātajā vai publiskajā sektorā. Lai gan sākotnēji ieinteresētība bija lielāka, nekā cerēts un jau drīz vien 220 augsti kvalificēti igauṇi no 35 valstīm bija piereǵistrējušies speciāli izveidotajā portālā (www.talendidkoju.ee), projekts 2012. gadā tika slēgts un vairs netika turpināts, jo izrādījās, ka programma nav sevi attaisnojusi: no kopumā apmēram 5000 igauṇu studentiem, kuri 2010. gadā studēja ārvalstīs, programmai noslēdzoties 2012. gadā, tikai apmēram 20 speciālisti pēc studijām bija atgriezušies Igaunijā. Lietuvā līdzīga programma "Talantus Lietuvai” (liet. - Talentai Lietuvai; angl. - Talents for Lithuania) cenšas piesaistīt lietuviešus, kas absolvējuši ārvalstu universitātes, ar apmaksātu stažěšanos Lietuvas uzṇēmumos. Šãdas stažēšanās ilgums ir seši mēneši (Renkuosi Lietuvą, 2020). Detalizētāka informācija par šĩs programmas rezultātiem nav pieejama, bet Lietuvā ir izveidota arī jauno profesionāḷu atbalsta programma "Radi Lietuvai" (liet. - Kurk Lietuvai; angl. - Create Lithuania), kas tika uzsākta 2012. gadā. Šīs programmas mērḳis ir piesaistīt jaunos lietuviešu profesionāḷus, kas dzīvo 
ārpus Lietuvas, ārvalstu labo prakšu ieviešanai Lietuvā. Katru gadu 20 dalībnieki sniedz konsultācijas valsts un pašvaldību iestādēm dažādos jautājumos saistībā ar Lietuvas tēla un biznesa vides uzlabošanu. Laikā no 2012. gada līdz 2019. gadam šajā programmā ir iesaistījušies 185 jaunie lietuviešu profesionāḷi no ārvalstīm, īstenojoši 222 projektus, un 80\% no viṇiem ir palikuši dzīvot Lietuvā (Create Lithuania, 2020).

Līdzīgas programmas īsteno arī citas jaunās ES dalībvalstis. Piemēram, Bulgārijas Migrācijas un integrācijas stratēg̣ijas ietvaros ir izstrādāta programma, lai jauni, kvalificēti Bulgārijas pilsoṇi, kuri dzīvo ārzemēs, varētu pastāvīgi atgriezties Bulgārijā. Programma ietver vairākas aktivitātes: (1) pētīt, ar kādām psihologiiskām, sociālām, kultūras, ekonomiskām un cita veida problēmām saskaras kvalificētie Bulgārijas emigranti, (2) piesaistīt Bulgārijas jaunatnes un biznesa organizācijas ārzemēs konsultācijām un biznesa attiecībām Bulgārijā, (3) veicināt kontaktus starp jaunajiem Bulgārijas emigrantiem un uzṇēmumiem Bulgārijā, (4) pētīt atbildīgo ārvalstu institūciju darbību, lai piesaistītu atpakal jaunos emigrantus. Precīzāka informācija par programmas īstenošanu Bulgārijā pētījuma veikšanas laikā nebija pieejama (Šūpule et al., 2016).

Kopumā literatūras avotu izpēte rāda, ka programmas, kas vērstas uz atbalstu tām grupām, kuras citādi varbūt neatgrieztos, ES jauno dalībvalstu kontekstā lielākoties ir diezgan dārgas, mazskaitlīgas un nereti tiek uzskatītas par neefektīvām, lai gan labi domātām. Šīm programmām var būt nozīme atsevišķu indivīdu profesionālās karjeras veidošanā izcelsmes valstī, bet lielākoties tām nav būtiska efekta valsts mērogā. Cita, ievērojami pozitīvāka pieredze ir vairākām Āzijas valstīm, piemēram, K̦īnai un Taivānai, bet jāuzsver, ka šajās valstīs augsti kvalificētu speciālistu remigrācijai uzmanība ir pievērsta daudz agrāk (sākot no 1980. gada), un sekmīgu tās īstenošanu veicina emigrantu kopējais lielais skaits (apjoms).

\section{SADARBĪBAS AR DIASPORU POLITIKA}

Citu valstu pieredzes analīze rāda, ka diasporas politikas iniciatīvas, lai veicinātu zināšanu pārnesi, investīciju piesaisti, eksportu un profesionāḷu tīklošanos, ir būtiskas izcelsmes valsts attīstîbai, kā arī var sekmēt augsti kvalificētu speciālistu atgriešanos (Hooper \& Sumption, 2016; Tejada et al., 2014). Pasākumus sadarbībai ar diasporu valstis lielākoties īsteno ar vēstniecību un attīstības aǵentūru pārstāvniecību starpniecību. Galvenie sadarbības veidi ir tīklošanās, mentorings, kā arī investīciju un ziedošanas veicināšana. Tīklošanās aktivitātes starp diasporas un izcelsmes valsts speciālistiem veicina gan sadarbības iespējas, gan zināšanu pārnesi. Mentorings ir vērsts uz 
personiskāku atbalsta sniegšanu izcelsmes valsts speciālistiem noteiktās jomās (Hooper \& Sumption, 2016).

Starptautiski diasporas sadarbības tīklu piemēri ir Advance Australia, RedEsColombia, GlobalScot, Chile Global, Indus Entrepreneurs, kas atklāj dažādas pieejas un mērkgrupu izvēles sadarbības veicināšanā. Daudzpusīgu un aktīvu diasporas politiku īsteno Indijas valdība - 2004. gadā tika izveidota speciāla diasporas ministrija (Ārvalstu indiešu lietu ministrija). Pasaulē kopumā ir 11 valstis, kurās ir diasporas ministrijas (Singh, 2012). Indijā ir izveidota arī Indiešu izcelsmes karte un Indijas ārvalstu pilsonības karte, lai veicinātu diasporas piederības sajūtu Indijai. Vairāku ministrijai paḳ̣autu iestāžu tīkls sniedz atbalstu gan attīstības sadarbības jautājumos ar indiešiem ārvalstīs, gan filantropijas organizēšanai, gan darba tirgus nosacījumu izvērtěšanai un uzlabošanai. Indijā ir izveidota arī Globālā indiešu zināšanu sadarbības platforma (angl. - the Global Indian Network of Knowledge) (Singh, 2012).

Kopumā dažādās diasporas politikas prakses, kas vērstas uz sadarbības veicināšanu ar augsti kvalificētiem speciālistiem, var nosacīti iedalīt šādos apakšvirzienos: (1) diasporas uzṇēmēju, zinātnieku un profesionāļu datubāzu veidošana; (2) profesionālie tīklošanās portāli, diasporas mājaslapas; (3) dažādu diasporas forumu un tikšanos organizēšana; (4) mentoringa programmas.

Diasporas uzṇēmēju, zinātnieku un profesionāḷ datubāzu veidošana ir nepieciešams instruments, lai veidotu jebkāda veida sadarbību ar diasporas uzṇēmējiem: gan lai aicinātu uz dažādiem pasākumiem (konferencēm, semināriem), gan lai atrastu konsultantus, gan lai veicinātu viṇu uzṇēmējdarbību izcelsmes valstī vai piesaistītu kā investorus (Hooper \& Sumption, 2016; Petkevičienè, 2016).

Profesionālie tīklošanās portāli, diasporas mājaslapas sniedz iespēju diasporas pārstāvjiem sekmīgāk atrast sadarbības partnerus un uzturēt ar tiem kontaktus, balstoties uz kopējām interesēm vai atrašanās vietu. Šādi portāli parasti tiek veidoti vai nu pēc izcelsmes valsts valdības, vai diasporas organizāciju iniciatīvas. Zināmākie diasporas profesionālās tīklošanās piemēri ir Advance Australia un GlobalScot projekti, kā arī Global Lithuanian Leaders projekts (http://lithuanianleaders.org), kurā iniciatīva Business advisors izmanto tīklošanos, lai atrastu ekspertus, kas konsultē Lietuvas uzṇēmējus par eksporta iespējām diasporas pārstāvja mītnes valstī (Aikins \& White, 2011; Gudelis \& Klimavičiūtè, 2016).

Padziḷināti apzinot ārvalstu pieredzi, kā veidot sadarbības platformu diasporas profesionāliem un uzṇēmējiem, jāsecina, ka Eiropā nav daudz valstu, kur šādas diasporas sadarbības platformas ir izveidotas. Zināmākie sadarbības 
platformu piemēri ir İrijā, Skotijā un Lietuvā (Šūpule et al., 2016). Ārpus Eiropas diasporas profesionāḷu sadarbības platformas ir Austrālijā un Čīlē. Viens no slavenākajiem diasporas uzṇēmēju sadarbības tīkliem ir Skotijā izveidotais GlobalScot. To 2001. gadā radīja valsts aǵentūra Scottish Enterprise, un tas ir daḷēji noslēgts tīkls, jo mentoringa pakalpojumu sniegšanai tiek uzaicināti pieredzējuši uzṇēmēji, kuriem uzaicinājumu nosūta augsti stāvoša amatpersona (Skotijas Pirmais ministrs). GlobalScot piedāvā jaunajiem uzṇēmējiem mentoringa pakalpojumus, palīdz jaunajiem uzṇēmējiem identificēt biznesa iespējas Skotijā, kā arī piedāvā atbalstu biznesa īstenošanā, piemēram, izstrādāt biznesa plānu un piesaistīt investīcijas. 2011. gadā GlobalScot tīklā bija iesaistīti 650 pieredzējuši skotu izcelsmes uzṇēmēji, un piederība šim tīklam ir saistīta ar augstu prestižu. Katru gadu GlobalScot organizē apmēram 60 dažādus pasākumus (Hooper \& Sumption, 2016; Rannveig \& Newland, 2012).

Lietuvā katru gadu notiek Lietuviešu ekonomikas forums, kas pulcē vadošos starptautiska un vietējā līmeṇa uzṇēmējus no dažādām nozarēm, ir izveidots apbalvojums “Globālā Lietuva”, kā arī profesionāḷu tīkls Global Lithuanian Leaders. Šì iniciatīva attīstījās pēc pirmā Vispasaules Lietuviešu ekonomikas foruma 2009. gadā un nu jau iekḷauj ap 700 dalībnieku no gandrīz 40 valstīm visā pasaulē. Iniciatīvas ietvaros tiek īstenoti projekti, kas vērsti uz talantīgu jauniešu atgriešanu mājās un atbalstu uzṇēmējiem. Šì iniciatīva ietver arī profesionāḷu datubāzes uzturēšanu un mentoringa programmu. Iniciatīvas darbību nosaka Vienošanās memorands starp valsts pārvaldes institūcijām un trīspusējais līgums starp Ārlietu ministriju, Global Lithuanian Leaders un Ekonomikas ministrijas pakḷautības iestādi - bezpeḷnas aǵentūru Enterprise Lithuania. Programmas īstenošana tiek nodrošināta ar valsts finansējumu, nevalstisko organizāciju un iesaistīto personu līdzfinansējumu (Damušis, 2014).

İijā ir izveidota Īrijas tehnologiju līderu grupa, ko dibinājis Džons Hārtnets (John Hartnett). Tās mērḳis ir ASV tehnoloğisko uzṇēmumu investīcijas İijā, lai atbalstītu Îrijas tehnoloǵiju kompāniju globālo izaugsmi un attīstību. Tā ir bezpeḷnas organizācija, kas bāzējas Silīcija ielejā, dibināta 2007. gadā un domāta îru vai îru-amerikāṇu izcelsmes tehnoloǵiju līderiem. İrijas tehnoloğiju līderu grupa ir tīkla organizācija Îrijas jaunuzṇēmumiem un mazajiem uzṇēmumiem, kuri vēlas piesaistīt partnerus un finansējumu no ASV. Īrijas tehnoloǵiju līderu grupā ir 1500 biedru, un tā organizē vizītes, seminārus un inovāciju balvu ceremonijas. 2009. gada jūlijā Īrijas tehnolog̣iju līderu grupa parakstīja transatlantisku līgumu ar Trinitijas koledžu (angl. - Trinity College Dublin) un Universitātes koledžu (angl. - University College Dublin), lai 
radītu jaunas uzṇēmējdarbības un inovāciju iespējas Īrijas uzṇēmumiem. Viens no mērḳiem ir veidot riska fondu tiem uzṇēmumiem, kuri darbojas šo koledžu pētniecības centrā. Riska fonds paredzēts arī tam, lai potenciālie investori ar atbalstu no İrijas valdības varētu ieguldīt savu naudu jaunajos uzṇēmumos, kam nepieciešamas investīcijas (Irish Technology Leadership Group, 2018).

Chile Global (the Talent Network for Innovation) ir sadarbības tîkls, lai veicinātu inovācijas un jauno tehnologiiju izmantošanu Čìlē. Šajā sadarbības tīklā ir reǵistrēti apmēram 400 ietekmīgi čīlieši, kas dz̄ivo ASV, Kanādā, Meksikā, Brazīlijā, Argentīnā, Austrālijā, K̄innā, Spānijā, Zviedrijā un Lielbritānijā. Sadarbības tīkls palīdz izstrādāt biznesa plānus un piesaistīt investīcijas inovāciju projektiem. Chile Global ir slēgts tīkls, kas izveidots 2005. gadā. To dibinājusi organizācija Fundación Chile, un tas piesaista dažādus resursus, tai skaitā finansējumu no Čīles Ārlietu ministrijas Eksporta veicināšanas aǵentūras (angl. - ProChile - the Export Promotion Agency of the Ministry of Foreign Relations) un Čìles Ekonomiskās attīstības aǵentūras (angl. - CORFO the Chilean Economic Development Agency).

Advance Australia ir sadarbības tīkls, ko 2002. gadā izveidojusi Austrālijas centrālā valdība kopā ar Austrālijas štatu vadību un privātajiem partneriem. Sadarbības tīkla mērḳis ir veicināt biznesa saites un atgriešanos Austrālijā. Sadarbības tīkls piedāvā informāciju par repatriāciju un forumu, kurā tiek izvietota informācija par darba iespējām. Sadarbības tīklam ir arī vairāki konkrētu nozaru tīkli, piemēram, finanšu pakalpojumu sadarbības tīkls, dzīvības zinātṇu un zaḷo tehnoloǵiju sadarbības tīkls. 2015. gadā sadarbības tīklā bija 25000 dalībnieku no 90 valstīm (Hooper \& Sumption, 2016).

Minētie piemēri liecina, ka pastāv divas pieejas sadarbības tīklu izveidē: atvērtā pieeja ar plašu dalībnieku loku (Advance Australia), kur ir piedāvājums gan uzṇēmējiem, gan arī darba ṇēmējiem un potenciālajiem repatriantiem, un vairāk uz uzṇēmējdarbību vērstā pieeja, kur mērḳtiecīgi tiek piesaistīti augsta līmeṇa profesionāli sniegt mentoringa pakalpojumus jaunajiem uzṇēmējiem (GlobalScot, Irish Technology Leadership Group).

Citu valstu pieredzes izpēte rāda, ka sekmīgāki ir tie sadarbības tīklu modeḷi, kur dalībnieku piesaistes pamatā ir selektīvi stratēǵiska pieeja, kas vērsta uz sasniegumu kvalitāti, nevis kvantitāti (Rannveig \& Newland, 2012: 139). Galvenie izaicinājumi šādu platformu izveidē ir, pirmkārt, to uzturēšana ilgtermiṇā, otrkārt, politiskā atbalsta nodrošināšana, treškārt, elastīgas pieejas nodrošināšana, mainoties diasporas vajadzībām.

Dažādu diasporas forumu un tikšanos organizēšana un mentoringa programmas, lai veicinātu zināšanu pārnesi starp dažādu nozaru speciālistiem 
pasaulē un izcelsmes valstī, ir vērstas uz to, lai veicinātu ekonomisko sadarbību ar diasporu. Vienlaikus šo programmu blakus mērḳis ir veicināt augsta līmen̦a profesionāḷu piesaisti izcelsmes valstij cerībā, ka daḷa no šiem profesionāliem atgriezīsies. Diasporas profesionālu un uzṇēmēju konsultācijas tiek izmantotas gan eksporta, gan investīciju, gan inovāciju veicināšanas jautājumos. Attiecībā uz eksportu diasporas pārstāvji var palīdzēt ar ieteikumiem par eksporta stratēǵijām dažādos tirgos, var ieteikt dažādas pieejas, kā strādāt ar eksporta veicināšanu (filiāles atvēršana, tirdzniecības ağenti, sadarbība ar vietējiem uzṇēmējiem utt.), kā veidot eksporta komunikācijas stratēgeijas. Tāpat diasporas uzṇēmēji var konsultēt par investīciju piesaistes iespējām konkrētās nozarēs vai valstīs un palīdzēt izcelsmes valsts uzṇēmumiem meklēt sadarbības partnerus ārzemēs. Piemēram, lietuviešu profesionāḷi ārvalstīs konsultē Lietuvas uzṇēmumus un inovatorus (sadarbībā ar Enterprise Lithuania).

Lietuvā ekonomiskajai sadarbībai ar diasporu ir atvēlētas vairākas aktivitātes, šeit pieminētas tikai nozīmīgākās. Pirmkārt, katru gadu tiek organizēts Lietuviešu ekonomikas forums, kas pulcē vadošos starptautiska un vietējā līmeṇa uzṇēmējus no dažādām nozarēm. Otrkārt, Lietuvā ir uzsākta mentoringa programma “Globālie lietuviešu līderi”, kas iever arī profesionāḷu datubāzes izveidi.

Bulgārijā katru gadu tiek rīkots forums "Karjera Bulgārijā. Kāpēc ne?”. Foruma laikā studenti un augstas kvalifikācijas speciālisti dalās pieredzē par darbu un studijām ārzemēs un Bulgārijā. Forumā piedalās vietējie uzṇēmumi, lai kopīgi rastu vidusceḷu par iespējām strādāt un palikt Bulgārijā, apvienojot bulgāru ārzemju darba un studiju pieredzi. Rumānijā 2016. gadā ir uzsākta diasporas jaunuzṇēmumu programma, kurāārvalstīs dzīvojoši rumāṇi var pieteikt projektu, lai iegūtu finansējumu un piedalītos interneta biznesa apmācību programmās. Albānijā 2005. gadā darbojās prakses programmas studentiem, kur Albānijas ministrijas, bankas un zinātniskie institūti piedāvāja prakses iespējas, lai iedvesmotu studentus palikt Albānijā. Uz 60 prakses vietām tika saṇemti 550 pieteikumi. Programmas finansējumu nodrošināja Vācijas vēstniecība. Diemžēel nav pieejama informācija, vai šì programma tiek turpināta.

Salīdzinoši l̦oti izvērsta ekonomiskās sadarbības programma ar diasporu ir izstrādāta Îrijā. Īrijas diasporai ir daudz dažādu privātu iniciatīvu ekonomiskās sadarbības veidošanai. Piemēram, darbojas jau pieminētā Īrijas tehnoloğiju līderu grupa, kā arī biznesa tīklu veidošana ar tiešsaistes programmas Irish Executive Mentoring Program palīdzību, kurā īru izcelsmes cilvēki dalās pieredzē par uzṇēmumu veidošanu un uzturēšanu, lai varētu atpazīt biznesa talantus diasporas vidū. 
Šajā nodaḷā aprakstîtās aktivitātes sadarbībā ar diasporu kopumā ir vērstas uz pozitīvas ekonomiskās ietekmes veicināšanu, un 6.2. tabulā ir sniegts Aimē Kuvikas (Aimee Kuvik) apkopojums par augsti kvalificētu speciālistu migrācijas iespējamo pozitīvo un negatīvo ekonomisko ietekmi gan uz migrantus nosūtošajām valstīm, gan uzṇemošajām valstīm, kā arī iespējamā globālā ietekme. Galvenā pozitīvā ietekme, pateicoties kvalificētu speciālistu mobilitātei un starptautiskajai konkurencei, ir saistāma ar starptautisku zinātnes un tehnoloǵiju attīstîbu, īpaši attīstības centros. Savukārt galvenā negatīvā ietekme ir saistīta ar "smadzeṇu aizplūšanu” no uzṇemošajām valstīm un produktivitātes zaudēšanu, samazinoties augsti kvalificētu speciālistu un studentu skaitam uzṇemošajās valstīs.

Turpinājumā ir apkopota Latvijas pieredze remigrācijas veicināšanā un sadarbībā ar diasporu.

\subsection{LATVIJAS PRAKSE}

Lai gan remigrācijas atbalsta un sadarbības ar diasporu politika Latvijā atsevišķos aspektos ir îstenota jau kopš 1991. gada, īpašu vērību tā ieguva pēc ekonomiskās recesijas 2009.-2010. gadā. Pirms 2008. gada politisko retoriku raksturoja emigrācijas procesu ignorēšana vai pat emigrantu nosodīšana (Dzenovska, 2015), taču brīdī, kad emigrācijas apjomi būtiski pieauga, aktualizējās diskusijas par nepieciešamību mazināt aizbraukšanu un veicināt tautiešu atgriešanos. Lai sekmētu atbalsta sniegšanu ārzemēs dzīvojošajiem Latvijas piederīgajiem un viṇu ǵimenes locekḷiem, kuri vēlas atgriezties Latvijā, 2012. gadā tika uzsākts darbs pie Reemigrācijas atbalsta pasākumu plāna 2013.-2016. gadam (2013) (turpmāk - Remigrācijas plāns). Remigrācijas plāns ietvēra daudzas aktivitātes, kas arī tika îstenotas, lai gan nepilnīgā apmērā.

Citi politikas plānošanas dokumenti, kas saistīti ar remigrācijas politikas īstenošanu Latvijā, šajā periodā bija Nacionālās identitātes, pilsoniskās sabiedrības un integrācijas politikas pamatnostādnes 2012.-2018. gadam, Valsts valodas politikas pamatnostādnes 2015.-2020. gadam, kā arī Latvijas Nacionālais attīstības plāns 2014.-2020. gadam. Savukārt Ārlietu ministrija, kas koordinē sadarbību ar diasporu, 2012. gada beigās un 2013. gada sākumā izstrādāja Informatīvo ziṇojumu par Ārlietu ministrijas sadarbību ar Latvijas diasporu 2013.-2015. gadā, kurā tika definēti Ārlietu ministrijas diasporas politikas četri galvenie rīcības virzieni: (1) veicināt diasporas politisko 
6.2. tabula. Augsti kvalificētu speciālistu migrācijas ekonomiskā ietekme

\section{Nosūtošās valstis: iespējamā pozitīvā ietekme}

Zinātne un tehnoloǵijas

Notiek zināšanu apmaiņa un sadarbība, vietējie speciālisti atgriežas ar uzkrātajām zināšanām un cilvēkkapitālu, veidojas ciešākas saites ar pētniecības institūtiem ārvalstīs

Palielinās jauno tehnoloǵiju eksporta iespējas Diaspora veic tiešos maksājumus un investīcijas legūta ārvalstu uzṇēmumu vadības un darba organizācijas pieredze

\section{Cilvēkkapitāls}

Vietējiem speciālistiem paaugstinās motivācija iegūt augstākas prasmes

Palielinās iespēja atgūt ieguldījumus personīgajā izglītībā

\section{Uzṇemošās valstis: iespējamā pozitīvā ietekme}

Zinātne un tehnologijas

Pateicoties papildu augsti kvalificētam darbaspēkam, paaugstinās zinātnes, attīstības un ekonomiskā aktivitāte

Attīstās uzṇēmējdarbība jomās ar augstu pievienoto vērtību

Notiek zināšanu apmaiṇa un sadarbība ar nosūtošajām valstīm Imigranti var veicināt dažādību un radošumu Palielinās jauno tehnoloǵiju eksporta iespējas

\section{Augstākā izglītība}

Palielinās studentu skaits, un ir iespējams saglabāt mazākās programmas

Samazinās mācībspēku novecošanās problēma

\section{Darba tirgus}

Izlīdzsvarojas algas nozarēs, kur ir liels darbaspēka pieprasījums un algas nemitīgi paaugstinās Imigrantu uzṇēmēji rada jaunus uzñēmumus un darbavietas

Imigranti ir kā magnēti, lai piesaistītu citus imigrantus

Nosūtošās valstis: iespējamā negatīvā ietekme

Cilvēkkapitāls

Notiek "smadzen,u aizplūšana", un mazinās Uzṇemošās valstis: iespējamā negatīvā ietekme Augstākā izglītība

Vietējiem studentiem samazinās iespējas noteiktās jomās, jo jākonkurē ar ārvalstniekiem

\section{Zinātne un tehnologijas}

Notiek tehnoloǵiju pārnese uz konkurējošām un, iespējams, naidīgām valstīm

\section{lespējamā pozitīvā globālā ietekme}

Notiek zināšanu apmaiṇa un sadarbība: iespēja veidot starptautiskus pētniecības un tehnoloǵiju klasterus (piemēram, Silīcija ieleja, CERN)

Augsti kvalificētiem speciālistiem rodas labākas iespējas atrast darbu, bet darba devējiem - atrast retas specializācijas profesionālus

Starptautiskā konkurence palielina ieguldījumus individuālajā cilvēkkapitālā

Avots: Kuvik, 2012: 228. 
un pilsonisko līdzdalību; (2) saglabāt diasporas saikni ar Latviju un latvisko identitāti; (3) stiprināt sadarbību ar tautiešiem ārzemēs ekonomikā, zinātnē, izglìtībā un kultūrā; (4) atbalstīt tautiešus, kas vēlas atgriezties Latvijā (Ārlietu ministrija, 2013).

Mediju uzmanību un publisko rezonansi remigrācijas kontekstā laikā no 2012. līdz 2016. gadam visvairāk radīja tieši Ekonomikas ministrijas izstrādātais Reemigrācijas atbalsta pasākumu plāns 2013.-2016. gadam. Tomēr jānorāda, ka šī plāna izpildē un plašāk - remigrācijas politikas īstenošanā - tika iesaistītas arī citas ministrijas un organizācijas. Ekonomikas ministrija koordinēja Remigrācijas plāna īstenošanas gaitu, un Ārlietu ministrija joprojām koordinē sadarbību ar diasporu. Kultūras ministrija koordinēja Nacionālās identitātes, pilsoniskās sabiedrības un integrācijas politikas pamatnostādṇu 2012.-2018. gadam īstenošanu, bet Pārresoru koordinācijas centrs uzrauga Nacionālā attīstības plāna îstenošanu.

Politikas plānošanas līmenī redzams, ka Reemigrācijas atbalsta pasākumu plāns 2013.-2016. gadam bija vērsts uz to, lai palīdzētu tiem ārzemēs dzīvojošajiem Latvijas piederīgajiem un viṇu gimenes locekḷiem, kuri vēlas atgriezties Latvijā. Nacionālās identitātes, pilsoniskās sabiedrības un integrācijas politikas pamatnostādnēs 2012.-2018. gadam norādīts, ka īpašs rīcībpolitikas virziens ir ārzemēs dzīvojošo latviešu atbalstīšana, stiprinot piederības sajūtu latviskajai kultūrtelpai, kas motivētu atgriezties Latvijā. Konkrēti pasākumi, kas vērsti uz atbalsta sniegšanu tiem, kuri ir atgriezušies, šajā plānošanas dokumentā netika paredzēti. Vienlaikus vairāki politikas mērḳi (2.2., 2.3., 2.4.) bija vērsti uz atbalstu diasporai, latviskās identitātes un piederības sajūtas stiprināšanu, saiknes ar diasporu veidošanu un uzturēšanu (Nacionālās identitātes, pilsoniskās sabiedrības un integrācijas politikas pamatnostādnes 2012.-2018. gadam, 2012).

Valsts valodas politikas pamatnostādnēs 2015.-2020. gadam (2014) 2. rīcības virziens "Valsts valodas politika" paredzēja sniegt tiešu un pastarpinātu atbalstu remigrantiem un viṇu bērniem - pirmkārt, nodrošinot latviešu valodas apguvi remigrantiem (2.1.2. uzdevums), otrkārt, pilnveidojot profesionālo kompetenci pedagogiem, kuri strādā ar remigrējušajiem bērniem (2.2.4. uzdevums).

Latvijas Nacionālajā attīstības plānā 2014.-2020. gadam kā vidēja termiṇa mērḳis bija noteikts “[340] Veicināt Latvijas iedzīvotāju palikšanu un Latvijas valsts piederīgo atgriešanos Latvijā”, un atbilstošā rādītāja sasniegšanai tika formulēts veicamais uzdevums: “[341] 5. Reemigrācijas veicināšana un ārzemēs dzīvojošo Latvijai piederīgo identitātes uzturēšana, t. sk. globālā tīkla 
attīstība, pasākumi Latvijā, izglìtības un kultūras pieejamība ārzemēs un atbalsta pasākumi reemigrācijas veicināšanai” (rīcības virziens "Cilvēku sadarbība, kultūra un pilsoniskā līdzdalība kā piederība Latvijai pamats”) (Latvijas Nacionālais attīstības plāns 2014.-2020. gadam, 2012).

Nozīmīgas remigrācijas politikas un sadarbības ar diasporu politikas aktivitātes tiek īstenotas arī ārpus minētajiem plānošanas dokumentiem. Piemēram, viena no politikām, kas vērsta uz to, lai samazinātu dažādas administratīvās barjeras Latvijas diasporas pārstāvjiem un viṇi varētu atgriezties Latvijā, ir dubultās pilsonības politikas īstenošana, ko nosaka 2013. gada 1. oktobrī spēkā stājušies Pilsonības likuma grozījumi (Šūpule et al., 2016). Tomēr Latvijā dubultpilsonība tiek pieḷauta tikai ar noteiktām valstīm vai valstu grupām. Grozījumi paredz, ka Latvijas pilsonība ir saglabājama personām, kuras ir ieguvušas:

- citas Eiropas Savienības dalībvalsts vai Eiropas Brīvās tirdzniecības asociācijas dalībvalsts pilsonību;

- citas Ziemel̦atlantijas līguma organizācijas dalībvalsts pilsonību;

- Austrālijas Savienības, Brazīlijas Federatīvās Republikas vai Jaunzēlandes pilsonību;

- tādas valsts pilsonību, ar kuru Latvija ir noslēgusi līgumu par dubultās pilsonības atzišanu (šobrīd neviens līgums nav noslēgts);

- iepriekš neminētas valsts pilsonību, ja saistībā ar svarīgām valsts interesēm būs saṇemta Ministru kabineta aț̣auja saglabāt dubultpilsonību;

- iepriekš neminētas valsts pilsonību, ja tā iegūta automātiski (ex lege) - apprecoties vai adopcijas dẹḷ (Pilsonības un migrācijas lietu pārvalde, 2016).

Saskaṇā ar A. Gemlena (Gamlen, 2006) diasporas politikas klasifikāciju dubultās pilsonības iespēju paplašināšana ir skatāma kā diasporas tiesību paplašināšanas politika, jo šī politika attiecas arī uz vēlěšanu tiesību paplašināšanu, iekḷaujot tajā diasporas pārstāvjus.

Līdzīgi arī ārvalstīs iegūtās izglîtības atzīšanas procedūras vienkāršošana ir viena no politikām, kas vērsta uz to, lai samazinātu dažādas administratīvās barjeras diasporas pārstāvjiem, kuri vēlas atgriezties izcelsmes valstī. Latvijā Izglītības likuma 11.1 pants regulē ārvalstīs iegūtās izglītības atzīšanas procesu Latvijā, to īsteno Akadēmiskās informācijas centrs, un tas ir maksas pakalpojums (Akadēmiskās informācijas centrs, 2016).

Remigrācijas atbalsta un sadarbības ar diasporu politikas veidošanā aktīvi iesaistās arī diasporas organizācijas, no kurām plašāk zināmās ir Pasaules 
Brīvo latviešu apvienība (PBLA) un Eiropas Latviešu apvienība. Tās īsteno dažādas aktivitātes, to skaitā dalību konsultatīvajos mehānismos politikas veidošanā, kā arī tīklošanās aktivitātes, piemēram, veicinot ekonomisko sadarbību ar diasporu. 2013. gada jūlijā Rīgā notika pirmais PBLA, Latvijas Tirdzniecības un rūpniecības kameras un Ārlietu ministrijas organizētais Pasaules latviešu ekonomikas un inovāciju forums (PLEIF). Pirmajā forumā piedalījās 350 dalībnieku. 2015. gada vasarā notika jau otrais PLEIF, ko organizēja PBLA ar Ārlietu ministriju, sadarbojoties ar partneriem (ar Latvijas Investīciju un attīstības aǵentūru, Ekonomikas ministriju, Amerikas Tirdzniecības palātu Latvijā, Latvijas Tirdzniecības un rūpniecības kameru, Rīgas Ekonomikas augstskolu un Latvijas Institūtu). Forumā piedalījās vairāk nekā 200 dalībnieku no 17 valstīm. 2015. gadā tika uzsākts pilotprojekts - Pasaules latviešu mentoringa programma, kuras mērḳis bija veicināt zināšanu pārnesi starp dažādu nozaru speciālistiem pasaulē un jaunajiem profesionāliem Latvijā, tika izveidots iespējamo mentoru saraksts, bet šobrīd trūkst informācijas par šī pilotprojekta rezultātiem un turpinājumu. 2016. gadā PLEIF tika organizēts Melnburnā, Austrālijā, 2017. gadā Čikāgā, ASV, bet 2018. un 2019. gadā - Valmierā. Vienlaikus Latvijas Investīciju un attīstības aǵentūra (LIAA) nodrošina informāciju un sniedz konsultācijas ārvalstīs dzīvojošajiem potenciālajiem uzṇēmējiem un investoriem par iespējām uzsākt uzṇēmējdarbību, pieejamām atbalsta programmām un mehānismiem, kā arī organizē ekonomikas forumus, konferences, diskusijas Latvijā un ārvalstīs ar ārvalstīs dzīvojošajiem latviešu uzṇēmējiem, tai skaitā amatpersonu un uzṇēmēju delegāciju vizīšsu laikā.

Remigrācijas plānā kā atsevišḳs rīcības virziens tika noteikta augstas kvalifikācijas speciālistu atgriešanās veicināšana, kas bija vērsta uz to, lai jaunieši, kuri ieguvuši augstāko izglītību ārvalstu augstskolās, atgrieztos Latvijā. Saskaṇā ar D. Makenzija un D. Janga remigrācijas politikas tipoloǵiju (McKenzie \& Yang, 2014) šis virziens atbilst otrajai pasākumu grupai “Atbalsts tām grupām, kas citādi varbūt neatgrieztos”.

Tā īstenošanai Valsts kanceleja izstrādāja remigrācijas programmu "Darbs valsts pārvaldē”, ko sāka īstenot 2015. gadā. Programmas mērḳis bija sekmēt to, lai jaunie speciālisti, kuri augstāko izglītību ieguvuši ārzemēs, atgrieztos Latvijā, kā arī kopumā ieinteresēt jauniešus darbam valsts pārvaldē. Programmas ietvaros 2015. gadā laika posmā no 1. jūnija līdz 31. decembrim pieci jaunieši stažējās valsts pārvaldes iestādēs: Konkurences padomē, Fiskālās disciplīnas padomē, Valsts administrācijas skolā, Lauku atbalsta dienestā un Latvijas Investīciju un attīstības aǵentūrā. 2016. gadā šajā programmā 
stažējās septinii jaunieši, bet 2017. gadā programmai netika pieškirts finansējums (Ekonomikas ministrija, 2017).

Šajā rīcības virzienā Remigrācijas plāns paredzēja arī pilnveidot procedūru studējošo kredītu dzēšanai speciālistiem, kuri augstāko izglītību ieguvuši ārvalstīs. Lai to sekmētu, 2014. gada 29. aprīlī tika veikti grozījumi Ministru kabineta 2001. gada 29. maija noteikumos Nr. 220 "Kārtība, kādā tiek piešḳirts, atmaksāts un dzēsts studiju kredīts un studējošā kredīts no kredītiestādes līdzekḷiem ar valsts vārdā sniegtu galvojumu”. 2015. gadā studiju kredīta dzēšana tika uzsākta 355 speciālistiem, tai skaitā 15 speciālistiem, kuri augstāko izglītību ieguvuši ārvalstīs, un studējošā kredīta dzēšana 173 speciālistiem, tai skaitā sešiem speciālistiem, kuri augstāko izglītību ieguvuši ārvalstīs. Savukārt 2016. gadā studiju kredīta dzēšana tika uzsākta 394 speciālistiem, tai skaitā pieciem speciālistiem, kuri augstāko izglītîbu ieguvuši ārvalstīs, un studējošā kredīta dzēšana 193 speciālistiem, tai skaitā četriem speciālistiem, kuri augstāko izglītību ieguvuši ārvalstīs (Ekonomikas ministrija, 2017).

Piektais Remigrācijas plāna rīcības virziens ir sadarbība ar diasporu, it īpaši biznesa saiknes veidošana un uzturēšana. Šis rīcības virziens ir uzskatāms par sadarbības ar diasporu politikas aktivitāti. Saskaṇā ar A. Gemlena (Gamlen, 2006) identificētajiem trīs diasporas iesaistes politikas tipiem tas atbilst gan kapacitātes veidošanas politikai, kas vērsta uz tādas institucionālas struktūras veidošanu, kura nodrošina komunikāciju ar diasporu, gan arī diasporas pienākumu veidošanas politikai, kura parasti ir vērsta uz ekonomiskās sadarbības stiprināšanu, lai izcelsmes valsts gūtu jaunas investīcijas vai citu kapitālu. Aktīvākās šajā jomā ir Ārlietu ministrija, Ekonomikas ministrija un Latvijas Investīciju un attīstības aǵentūra, kas amatpersonu vizītēs un citos pasākumos regulāri organizē tikšanos ar ārvalstīs dzīvojošajiem tautiešiem. Šeit pieskaitāmas arī iepriekš minētās PBLA un sadarbības partneru aktivitātes, piemēram, Pasaules latviešu ekonomikas un inovāciju foruma organizēšana.

Sadarbība ar diasporas organizācijām izpaužas kā to iesaiste dažādos konsultatīvajos procesos: darba grupās, sabiedriskajās apspriedēs u. tml. 2015. gada rudenī pēc Ministru prezidentes Laimdotas Straujumas priekšlikuma Ministru prezidenta biroja paspārnē tika izveidota augsta līmeṇa diasporas izcelsmes uzṇēmēju konsultatīvā padome.

Septītais Remigrācijas plāna virziens paredz, ka valsts iestādēm vai kapitālsabiedrībām ir jābūt atvērtām Latvijas valstspiederīgajiem amatu pretendentiem, kas dzīvo ārzemēs. Tādēḷ, lai veicinātu ārvalstīs dzīvojošo tautiešu pieteikšanos darbam valsts pārvaldē, tika aicināts darba intervijas ar 
amatu pretendentiem nodrošināt arī attālināti, izmantojot tīmekḷa saziṇas iespējas (Valsts kancelejas direktores un ekonomikas ministra kopīgi parakstīta 2013. gada 10. janvāra vēstule Nr. 232-2/35). Atbilstoši jau minētajai remigrācijas politikas tipoloǵijai (McKenzie \& Yang, 2014) tie ir reintegrācijas atbalsta pasākumi. Tomēr joprojām tikai daḷa valsts pārvaldes iestāžu izmanto iespējas veikt attālinātas atlases intervijas (galvenokārt Skype vai telefonintervijas). Viens no galvenajiem iemesliem, kāpēc iestādes neizmanto Skype intervijas, ir tas, ka dienesta datoros informācijas drošības dēl šì programma netiek instalēta. Līdz ar to šī rīcības virziena īstenošana nav uzskatāma par īpaši sekmīgu (Ekonomikas ministrija, 2017).

Remigrācijas atbalsta un sadarbības ar diasporu politika Latvijā pēc Remigrācijas plāna darbības termiṇa beigām nav pārtraukta, un remigrācijas atbalsta pasākumi, kas izriet no institūciju pastāvīgajiem uzdevumiem, tiek turpināti.

Kā nozīmīga iniciatīva, kas uzsākta 2018. gadā un joprojām turpinās, jāatzīmē Vides aizsardzības un reǵionālās attīstības ministrijas un plānošanas reğionu īstenotais projekts "PAPS” ("Palīdzam atgriezties pašu sētā”). Iniciatīvas rezultātā ir izveidots piecu reǵionālo remigrācijas koordinatoru tīkls, nodrošinot vienu reǵionālo koordinatoru katrā plānošanas reǵionā. Koordinatori palīdz aizbraukušajiem atgriezties mājās, bet pašvaldībām - atgūt savus iedzīvotājus. Ikvienam interesentam ir iespēja bez maksas saṇemt reǵionālā koordinatora konsultāciju par sev aktuāliem jautājumiem, kas saistīti ar atgriešanos konkrētā Latvijas reǵionā (paps.lv, 2020). Koordinators vienlaikus ir atbalsta persona, kas palīdz ārvalstīs esošajiem tautiešiem attālināti izvērtēt atgriešanos Latvijā un sagatavoties tai. Laikā no 2018. gada marta līdz 2020. gada martam reǵionālie koordinatori ir snieguši 4827 konsultācijas un palīdzējuši atgriezties Latvijā 463 ǵimenēm (paps.lv, 2020).

No 2017. līdz 2018. gadam galvenais diasporas politiku regulējošais dokuments bija Nacionālās identitātes, pilsoniskās sabiedrības un integrācijas politikas pamatnostādnes 2012.-2018. gadam, kurās ir rīcībpolitikas virziens - ārzemēs dzīvojošo latviešu atbalstīšana. Šì virziena aktivitātes ir vērstas uz to, lai stiprinātu piederības sajūtu latviskajai kultūrtelpai. Saskaṇā ar A. Gemlena (Gamlen, 2006) tipoloǵiju tā ir kapacitātes veidošanas politika sadarbībai ar diasporu. Pasākumi, kas vērsti uz atbalsta sniegšanu tiem, kas ir atgriezušies, šajā plānošanas dokumentā nav paredzēti, bet ir atrodami citos politikas plānošanas dokumentos, piemēram, Valsts valodas politikas pamatnostādnēs 2015.-2020. gadam, kur ir aktivitātes latviešu valodas apguves sekmēšanai remigrantiem un viṇu bērniem un atbalstam pedagogiem, kas strādā 
ar remigrējušajiem bērniem, bet tiešs atbalsts, lai veicinātu augsti kvalificētu speciālistu atgriešanos, pagaidām nav plānots.

2019. gada 1. janvārī stājās spēkā Diasporas likums, kura mērḳis ir stiprināt diasporas kā neatṇemamas Latvijas sabiedrības daḷas latvisko identitāti un piederību Latvijai, sekmēt latviešu valodas un kultūras saglabāšanu diasporā, kā arī atbalstīt un veicināt diasporas pilsonisko un politisko līdzdalību (Diasporas likums, 2018). Diasporas likums bija nepieciešams, lai pilnveidotu līdzšinējo Latvijas valsts atbalsta politiku diasporas jautājumos, nodrošinātu iespēju īstenot sistēmisku un sistemātisku darbu ar reemigrantiem, kā norādīts likumprojekta anotācijā. Saskaṇā ar Diasporas likumu galvenā diasporas politiku koordinējošā valsts institūcija Latvijā ir Ārlietu ministrija.

Pašreizējo situāciju ekonomiskajā sadarbībā ar diasporu raksturo gan valstiska līmeña aktivitātes, gan diasporas organizāciju un domubiedru grupu iniciatīvas. Valsts līmenī sadarbību ar diasporu īsteno LIAA pārstāvniecības ārvalstīs un Ārlietu ministrija. Pēdējās aktualitātes attiecībā uz diasporas politikas pilnveidi ir saistītas ar darbu pie diasporas politikas plānošanas dokumenta "Rīcības plāns darbam ar diasporu 2021.-2023. gadam". Ar to strādā Diasporas konsultatīvā padome, kas izveidota 2019. gada 14. maijā, balstoties uz Diasporas likumā noteikto (Ārlietu ministrija, 2020).

LIAA pārstāvniecības ārvalstīs sniedz informatīvu atbalstu par biznesa attīstīšanu konkrētajā ārvalstu tirgū, tirgus specifiku un nodrošina atbalstu eksporta veicināšanā. Pašlaik Latvijas ārējās ekonomiskās pārstāvniecības darbojas ASV, Apvienotajos Arābu Emirātos, Baltkrievijā, Dānijā, Francijā, Itālijā, Japānā, Kazahstānā, Krievijā, Ḳ̄nā, Lielbritānijā, Lietuvā, Nīderlandē, Norvēǵijā, Polijā, Singapūrā, Somijā, Ukrainā, Vācijā un Zviedrijā.

LIAA cieši sadarbojas ar Latvijas Republikas Ārlietu ministriju un diplomātiem, kas ir atbildīgi par ekonomiskajiem jautājumiem vairāk nekā 50 valstīs. Ārlietu ministrijas diplomātisko un konsulāro pārstāvniecību sadarbība ar diasporu arī ietver ekonomiskās sadarbības aspektus, piemēram, goda konsulu darbā. Latvijai ir 47 diplomātiskās un konsulārās pārstāvniecības: 37 vēstniecības, sešas pastāvīgās pārstāvniecības, viens generālkonsulāts un divi konsulāti, viena konsulārā nodạ̣a (Kạ̣iṇingradā). Latvijas diplomātisko un konsulāro pārstāvniecību uzdevums ir arī organizēt dažādus pasākumus, kuru mērḳgrupa ir diaspora. Pasākumu klāsts ietver valsts svētku pieņemšanas, izstādes, koncertus, Jānu, Ziemassvētku un citu Latvijai nozīmīgu svētku svinēšanu. Minēto pasākumu organizēšanā iesaistās diasporas organizācijas (Šūpule et al., 2016).

Diasporas organizāciju vidū kā nozīmīgākās aktivitātes jāmin PBLA organizētie Pasaules latviešu ekonomikas un inovāciju forumi (http://www.pbla.lv), 
diasporas mediju un organizāciju rīkotie pasākumi, kā arī PBLA atbalstītā biedrība "Ar pasaules pieredzi Latvijā".

Biedrība "Ar pasaules pieredzi Latvijā” darbojas Latvijā, un šajā grupā mēgināts apvienot trīs dažādas latviešu profesionāḷu vai jauno uzṇēmēju grupas: (1) tos, kas ir aizbraukuši no Latvijas uz ārzemēm mācīties, strādājuši tur un tagad atgriezušies vai vēlas atgriezties Latvijā; (2) otrās un trešās paaudzes diasporas latviešus - jauniešus, kas ir pārcēlušies un Latviju; (3) latviešu jauniešus, kam ir atvērts un globāls skatījums uz biznesa iespējām pasaulē un kas vēlas veidot Rietumu tipa biznesa uzṇēmumus.

Biedrības “Ar pasaules pieredzi Latvijā” darbības veids ir aizgūts no Baltijas-Amerikas Brīvības fonda absolventu tīklošanās pasākumiem, kur cilvēki neformālā atmosfērā satiekas un stāsta par savu profesionālo pieredzi. Tā ir iespēja iepazīties ar līdzīgi domājošiem cilvēkiem, kuri jau ir kaut ko sasnieguši vai kuriem ir dažādas interesantas idejas, ko viṇi vēlas attīstît paši vai kopā ar sadarbības partneriem. Pirmajā domubiedru grupas “Ar pasaules pieredzi Latvijā” pasākumā Rīgā 2016. gada rudenī tikās 45 šādi jaunie profesionāḷi vai uzṇēmēji. Iniciatīvas autora motivācija veidot domubiedru grupu ir saistīta ar vēlmi veidot profesionālus kontaktus Latvijā, un līdz 2020. gada sākumam tā aktīvi darbojās.

Jānis Kreilis, biedrības “Ar pasaules pieredzi Latvijā” iniciators, ir izveidojis arī portālu Your Move (https://www.yourmove.lv), kura mērkisis ir palīdzēt remigrantiem attīstīt veiksmīgu karjeru un iekārtoties uz dzīvi Latvijā. Your Move ir pievienojušies vairāk nekā 30 vadošie uzṇēmumi Latvijā. Sevi reklamējot, YourMove.lv norāda, ka ir darba un informācijas portāls, kas savieno profesionāḷus ar pasaules pieredzi un uzṇēmumus Latvijā, kuri šo pieredzi spēj novērtēt, kā arī apkopo uzziṇas par darba tirgu un iekārtošanos uz dzīvi Latvijā.

Starp citām aktivitātēm jāmin arī, ka diasporas medijs Latviesi.com cenšas nodrošināt kopienas komunikācijas platformu, lai veicinātu globāla Latvijas valstspiederīgo tīkla izveidi, un šajā platformā ir paredzētas apakšsadaḷas uzṇēmējiem. Cits piemērs ir iniciatīva UK and Latvian Business Network (https://www.uklbn.com). Balstoties uz Facebook grupu, šì iniciatīva darbojas jau trīs gadus, tās biedru skaits pārsniedz 750 dalībniekus. Reizi divos mēnešos vai biežāk interesenti tiekas lielākoties Londonā (dažreiz Latvijas vēstniecības telpās, pēdējā laikā - Daugavas Vanagu namā), bet ir bijuši arī pasākumi ārpus Londonas, piemēram, Liverpūlē. Sanākušie uzṇēmēji un profesionāḷi prezentē pārējiem savas aktivitātes, iepazīstas un pavada laiku ar aktīviem cilvēkiem Lielbritānijā. 
Pastāv arī citas vairāk vai mazāk aktīvas iniciatīvas, piemēram, LinkedIn grupa Latvian Professionals in London, draugiem.lv grupa "Tavs bizness Norvēǵijā” un citas.

Latvijā ir bijuši arī ne visai sekmīgi mēǵinājumi izveidot profesionālus tīklošanās portālus. Piemēram, mājaslapas www.laimeszeme.lv sākotnējā ideja bija veidot vietni, kur apvienot latviešus, kas dzīvo ārzemēs. Projekta ideja 2012. gadā bija radīt portālu, kas ḷautu tīkloties latviešiem visā pasaulē. Tika plānots, ka reǵistrējoties lietotājs pievienosies "kompetenču datubāzei”, lai saṇemtu piedāvājumus, kas atbilst viṇa kompetencēm, un informāciju par nodarbinātības jaunumiem Latvijā. Tika plānots aicināt uzṇēmējus un organizācijas publiskot savas vakances ārzemēs studējušajiem, kā arī piedāvājumus, kas veicami no attāluma un neprasa fizisku klātbūtni Latvijā (LETA, 2012). Diemžēl tagad var secināt, ka šis projekts nebija veiksmīgs.

Kopumā, izvērtējot Latvijas remigrācijas politiku laikā no 2012. līdz 2019. gadam, var secināt, ka šī politika ir vērsta gan uz remigrācijas atbalsta nodrošināšanu, gan sadarbības ar diasporu veicināšanu arī attiecībā uz augsti kvalificēto speciālistu mērķgrupu. Tomēr jānorāda, ka Reemigrācijas atbalsta pasākumu plānā 2013.-2016. gadam ietvertie rīcības virzieni ir īstenoti tikai daḷēji, un būtisks šḳērslis politikas sekmīgai ieviešanai ir bijis pasākumiem nepieciešamā finansējuma trūkums.

Aplūkojot Reemigrācijas atbalsta pasākumu plāna 2013.-2016. gadam īstenotās aktivitātes saskaṇā ar D. Makenzija un D. Janga remigrācijas politikas tipologiju (McKenzie \& Yang, 2014), kā arī A. Gemlena (Gamlen, 2006) diasporas iesaistes politikas tipologiju, redzams, ka galvenie pasākumi ir bijuši vērsti uz (1) dažādu šķērş̣̌u mazināšanu, kuri traucē atgriezties, (2) reintegrācijas atbalsta pasākumiem, kā arī (3) kapacitātes veidošanas politiku sadarbībai ar diasporu. Rezultatīvie rādītāji par aktivitātēm, kas vērstas uz augsti kvalificēto speciālistu mērḳgrupu, ir kopumā mazskaitlīgi (jauno speciālistu atgriešanās veicināšanas programma "Darbs valsts pārvaldē” un kredītu dzēšana speciālistiem, kuri augstāko izglītību ieguvuši ārvalstīs).

Attiecībā uz ekonomisko sadarbību ar diasporu jāsecina, ka līdzšinējā pieeja, kad sadarbība ar diasporas pārstāvjiem veidota, individuāli kontaktējoties ar atsevišķiem profesionāliem vai uzṇēmējiem, ir bijusi pareiza un ir turpināma, jo "no augšas" radītai sistēmiskai pieejai, veidojot un uzturot profesionālās tîklošanās portālus, diasporas mājaslapas ekonomiskai sadarbībai un diasporas uzṇēmēju datubāzes, visticamāk, nebūtu gaidītā efekta. Galvenais pamatojums šim pienēemumam ir saistīts ar diasporas profesionāḷu un 
uzṇēmēju skaitliski mazo pārstāvniecību un nozaru sadrumstalotību salīdzinājumā ar tādām lielām diasporām kā ebreju, indiešu vai îru diaspora.

Būtiski, ka vairākas ekonomiskās sadarbības iniciatīvas ir uzsākuši paši diasporas pārstāvji, tas vērtējams ḷoti pozitīvi un ir atbalstāms. Ar šādām iniciatīvām valsts iestādēm vajadzētu uzturēt kontaktus un sekot līdzi to attīstībai, izvērtējot iespējas tās stiprināt, lai uz to pamata veidotos noturīgākas kopienas, kas dibina, piemēram, savas nevalstiskās organizācijas un tādējādi var kḷūt par sadarbības partneri ekonomiskās sadarbības veicināšanai.

\section{SECINĀJUMI}

Apkopotā informācija par citu valstu labajām praksēm, veicinot augsti kvalificētu speciālistu atgriešanos, liecina, ka kopumā ir daudz dažādu iniciatīvu augsti kvalificētu speciālistu remigrācijai, bet trūkst informācijas par šo politiku efektivitāti. Pieejamā informācija l̦auj secināt, ka veiksmīgākās remigrācijas politikas un diasporas politikas ir īstenotas Ḳīnā, Indijā un Taivānā, vienlaikus jāatzīmē, ka tās ir politikas, kas uzsāktas daudz agrāk salīdzinājumā ar remigrācijas un diasporas politikām Austrumeiropā. Daudzās Rietumvalstīs tiek îstenotas atbalsta politikas, lai palīdzētu trešo valstu valstspiederīgajiem atgriezties savā izcelsmes valstī, bet atsevišķās salīdzinoši turīgās Rietumvalstīs ir arī aktīvas ekonomiskās sadarbības ar diasporu politikas, piemēram, Austrālijai vai Lielbritānijas Skotijas reǵionam.

Pievēršoties jauno ES dalībvalstu iniciatīvām mazināt emigrācijas negatīvās sekas un sekmēt "smadzeṇu apmaiṇu”, redzams, ka būtiskākās iniciatīvas ir vērstas uz jauno speciālistu un zinātnieku atbalstu un īstermiṇa piesaistīšanu, tajā skaitā stipendijām, grantiem un finansiālu atbalstu remigrantiem, darbavietu radīšanas veicināšanu un atbalstu tīklošanās un mentoringa aktivitātēm augsti kvalificētajiem diasporas speciālistiem. Visas minētās aktivitātes lielākā vai mazākā mērā tiek vai ir tikušas īstenotas arī Latvijā. Visbiežāk remigrācijas politikas un diasporas politikas ir vērstas uz universitātes līmeņa pasniedzēju un pētnieku remigrācijas veicināšanu, kā arī jauno uzṇēmēju piesaistī̌sanu.

Aplūkojot, cik lietderīga ir pētnieciskajā literatūrā identificētā remigrācijas politikas virzienu un sadarbības ar diasporu politikas klasifikācija šajā analīzē, jāsecina, ka D. Makenzija un D. Janga piedāvātais dalījums (McKenzie \& Yang, 2014) ir mazāk piemērots, lai pētītu tieši augsti kvalificētu speciālistu remigrācijas politiku, jo visas iniciatīvas lielākoties attiecas uz otro pasākumu 
grupu (finansiāla un cita veida atbalsta pasākumi tām grupām, kas citādi varbūt neatgrieztos). Vienlaikus šos pasākumus papildina arī atsevišķi reintegrācijas atbalsta pasākumi un aktivitātes, lai mazinātu dažādus šķēršlıs, kas traucē atgriezties (birokrātisko procedūru mazināšana, informācijas nodrošināšana), tomēr šīs iniciatīvas augsti kvalificētiem speciālistiem ir salīdzinoši mazāk nozīmīgas, jo ar šādiem šḳēšs̆liem augsti kvalificēti speciālisti lielākoties tiek labāk galā nekā citas mērkigrupas.

Vēl jāuzsver, ka gan Latvijas, gan citu jauno ES valstu pieredze rāda: programmas, kas vērstas uz atbalstu tām grupām, kas atgriežas un citādi varbūt neatgrieztos, lielākoties ir diezgan dārgas, mazskaitlīgas, nereti tiek uzskatītas par neefektīvām un sabiedrībā neviennozīmīgi vērtētas, tādēḷ netiek turpinātas (kā tas ir Latvijas un Igaunijas gadījumā).

Aplūkojot A. Gemlena diasporas iesaistes politikas trīs tipu izplatību dažādās valstīs (Gamlen, 2006), jāsecina, ka lielākā daḷa valstu aktīvāk vai mazāk aktīvi īsteno kapacitātes veidošanas politiku, tajā skaitā veidojot institucionālās struktūras un platformas komunikācijai ar diasporu, organizējot forumus un konferences. Mazāk izplatīta ir diasporas tiesību paplašināšanas politika, kas attiecas uz vēlēšanu tiesību paplašināšanu, iekḷaujot tajā diasporas pārstāvjus, kā arī uz emigrantu tiesību aizsardzību ārzemēs (šeit gan jāuzsver, ka Latvija nodrošina diasporas pārstāvjiem gan tiesības uz dubultpilsonību ar lielu dạ̣u attīstīto Rietumvalstu, gan arī iespēju piedalīties parlamenta vēlēšanās attālināti). Savukārt vislielāko vērību pēdējo 20 gadu laikā ir ieguvusi diasporas pienākumu veidošanas politika, kas vērsta uz ekonomiskās sadarbības stiprināšanu, lai izcelsmes valsts gūtu jaunas investīcijas, pieeju informācijas tehnoloǵiju un inovāciju apmaiņai un zināšanu pārnesei vai finanšu kapitālam, ko piesaista diasporas pārstāvji. Cilvēki ar uzṇēmējdarbības vai profesionālo pieredzi ārzemēs (gan tie, kuri ir atgriezušies izcelsmes valstī, gan tie, kas vēl dzīvo ārpus tās) bieži vien spēj saskatīt jaunas uzṇēmējdarbības iespējas, radīt inovatīvas idejas un pārrobežu sadarbības tīklus, veicinot zināšanu un tehnoloǵiju pārnesi un atbalstot ar savu pieredzi un zināšanām jaunus, perspektīvus uzṇēmumus savā izcelsmes valstī. Šì iemesla dēḷ ir svarīgi mazināt dažādus birokrātiskos šķēršlus, kas nereti rodas, uzsākot uzṇēmējdarbību vai profesionālo karjeru izcelsmes valstī. 
Šis pētījums aptver gan mikrolīmeni, gan makrolīmeni, gan mezolīmeni. Mikrolīmenī tās ir biogrāfiskās pieredzes, kas ietver arī reflektēšanu un komunikāciju par pārejas situācijām plašākā sociālā kontekstā. Mezolīmenī aplūkoti gan institucionalizēti, gan neformāli sociālie tīkli, kas izmantoti, lai iekḷautos jaunajā darba tirgū ārvalstîs. Makrolīmenis šajā pētījumā atklājas kā politiskais un normatīvais regulējums attiecībā uz migrantu iekḷaušanu konkrētajā valstī un nodarbinātības sektorā, kā arī remigrācijas politikas, ko īsteno dažādas valstis. Pētījumā izvirzītie četri pētnieciskie jautājumi aptver dažādus analīzes līmeṇus. Pirmais pētnieciskais jautājums par to, kā augsti kvalificēti Latvijas emigranti pielāgojas situācijai un darba tirgus prasībām uzṇemošajā valstī, analizēts kvalitatīvās izpētes perspektīvā. Analizējot padzilịnātās intervijas ar augsti kvalificētiem Latvijas emigrantiem un remigrantiem, izmantota naratīvo interviju dokumentārās interpretācijas metode, kas atklāja, kādas izmaiņas ikdienas pieredzēs rada migrācija, un dažādu pārejas situāciju faktologisko secību. Latvijas emigrantu darba trajektoriju izpēte parāda, ka pirmie darbi emigrācijā lielākoties ir kā stažieriem, mācekḷiem, jaunākajiem 
speciālistiem, praktikantiem, kā arī rezidentūras sākumposms ārstniecības iestādēs. Šìs pozīcijas ir saistītas ar lielāku statusa nedrošību, nepieciešamību intensīvi mācīties, laikietilpīgāku un zemāk atalgotu darbu. Pēc tam seko profesionālā nostabilizēšanās un karjeras attīstība. Padziḷinātās intervijas atklāj, ka dažādiem migrācijas posmiem raksturīgas atšḳirīgas adaptācijas stratēgeíjas, bet mītnes zemes valodas apguve pirmās paaudzes migrantiem ir aktuāla visos posmos.

Pirmsmigrācijas adaptācijas stratēǵijas l̦oti atšķiras dažādās nozarēs. Vienojošie aspekti saistās ar valodas zināšanu un profesionālo iemaṇu pilnveidi, kontaktu veidošanu un dažkārt arī rekomendāciju sagatavošanu. Ja migrācija ir saistīta ar augstākās izglîtības ieguvi, pirmsmigrācijas posma laikā emigranti iegūst informāciju par augstskolām un to piedāvātajām mācību programmām, nosacījumiem attiecībā uz iestājeksāmeniem, mācību maksu un stipendijas iespējām, kā arī kārto eksāmenus.

Pārejas posmā uzreiz pēc migrācijas un sākotnējās iedzīvošanās laikā Latvijas emigranti pielāgo Latvijā iegūtās zināšanas un prasmes jeb kultūras kapitālu mītnes valsts darba devēju prasībām. Šajā posmā daudziem darbs aizṇem lielāko daḷu laika, jo nepieciešams pilnveidot zināšanas arī pēc darba dienas beigām un brīvdienās. Daudziem sākuma periodā ir nepieciešams pilnveidot sevis pasniegšanas prasmes, un daudzi cenšas mācīties no citiem, kā pareizi runāt ar kolēgiem un klientiem, kā veidot savu tēlu, kā pasniegt sevi darba devējam izdevīgākā gaismā.

Nostabilizēěanās un iedzīvošanās mītnes valstī raksturīga ar to, ka parādās iespēja pakāpties pa karjeras kāpnēm vai attīstīt paralēlus projektus, piemēram, sadarbībā ar Latviju. Sadarbošanās ar Latviju aktualizē Latvijā iegūtā kultūras kapitāla izmantošanu, un vairākos gadījumos ir izveidoti uzņēmumi, kas nodrošina pakalpojumus saistībā ar Latviju un mītnes zemi. Juristi, finansisti, grāmatveži, IT speciālisti ir tās emigrantu grupas, kurām ir iespēja veidot šādus sadarbības biznesus ar Latviju un izmantot Latvijā iegūto pirmsmigrācijas kultūras kapitālu savienojumā ar migrācijas laikā iegūto kultūras kapitālu.

Otrais pētnieciskais jautājums par to, kas ir tie augsti kvalificētie Latvijas emigranti, kas apsver iespēju atgriezties Latvijā, un kādi faktori nosaka augsti kvalificēto emigrantu atgriešanos Latvijāa, analizēts, pielietojot gan kvantitatīvās analīzes metodes, gan padziḷināto interviju emigrantu dzīves trajektoriju kontekstā. Binārās loğistiskās regresijas analīze par faktoriem, kas ietekmē atgriešanās plānus Latvijā, atklāj: ciešas saites ar Latviju būtiski paaugstina varbūtību, ka augsti kvalificētie Latvijas emigranti plānos atgriezties. Ciemošanās Latvijā vismaz reizi pusgadā, tuvi draugi Latvijā un 
sekošana notikumiem Latvijā pozitīvi ietekmē atgriešanās plānus. Vienlaikus regulāra naudas sūtīšana radiniekiem vai draugiem Latvijā un māja vai dzīvoklis īpašumā Latvijā būtiski neietekmē vidēja termiṇa atgriešanās plānus. Šajos gadījumos atgriešanās, iespējams, ir plānota vēlāk vai vecumdienās. Savukārt ciešām saitēm ar uzṇemošo valsti ir negatīva ietekme uz plāniem atgriezties Latvijā. Būtiska negatīva ietekme uz plāniem atgriezties ir partnerattiecībām ar citas valsts personām un ilgstoša uzturēšanās emigrācijā. Pētījuma rezultāti par migrācijas motīvu ietekmi uz atgriešanās plāniem liecina, ka tikai neekonomiskie motīvi būtiski ietekmē plānošanu vai neplānošanu atgriezties Latvijā: to apsver tie emigranti, kas ir emigrējuši, lai apskatītu pasauli, gūtu jaunus iespaidus un draugus. Būtiski, ka tie, kas ir emigrējuši, jo viṇiem nepatika Latvijā notiekošie procesi un politiskā vide, neplāno tuvāko piecu gadu laikā atgriezties. Interesanti, ka augsti kvalificētie STEM jomās ar lielāku varbūtību apsver iespēju atgriezties Latvijā tuvāko piecu gadu laikā.

Pētījumā veiktā padziḷināto interviju analīze papildina izpratni par faktoriem, kas ietekmē atgriešanos Latvijā. Tā atklāj dažādu sabiedrības apakšsistēmu pārklāšanos un ietekmi migrācijas lēmumu pieṇemšanā. Piemēram, pamatojums atgriezties Latvijā saistās ar partnera vēlmi veidot ǵimeni Latvijā, neapmierinātību ar pārslodzi darbā, strādājot starptautiskā uzṇēmumā Londonā un pozitīvi vērtēto jauno ǵimeņu atbalstu Latvijā (maternitātes un vecāku pabalsts).

Trešais pētnieciskais jautājums par to, kā augsti kvalificētas Latvijas emigrantes vērtē savu emigrācijas pieredzi un kādi faktori palielina uztverto diskrimināciju darbavietā, analizēts, pielietojot galvenokārt kvantitatīvās analīzes metodes. Kvantitatīvā analīze vērsta uz trīs dažādiem uztvertās darba diskriminācijas veidiem: uztverto darba uzdevumu diskrimināciju, uztverto atvaḷinājumu diskrimināciju un uztverto darba algas diskrimināciju, jo uztvertā diskriminācija ir komplekss fenomens, un, izmantojot tikai vienu summāro diskriminācijas indikatoru, daḷa no pētījumā iegūtās informācijas tiktu zaudēta.

Binārās loğistiskās regresijas analīzes rezultāti kopumā apstiprina izvirzīto asimilācijas hipotēzi: jo ciešāk Latvijas emigrantes jūtas piederīgas mītnes valstij, jo mazāk tās uztver diskrimināciju, un otrādi. Jo mazāk emigrantes jūtas piederīgas mītnes valstij, jo lielāka varbūtība, ka tās izjūt diskrimināciju, konkrēti, viṇām ir lielāka varbūtība saskarties ar situāciju, kad viṇām biežāk nekā vietējiem uzdod neizdevīgus vai nepatīkamus darbus (uztvertā darba uzdevumu diskriminācija), un arī situāciju, kad par līdzīgu darbu viṇas saṇem mazāku atalgojumu nekā vietējie iedzīvotāji (uztvertā algu diskriminācija). 
Finanšu stāvokḷa novērtējums arī ietekmē uztverto diskrimināciju darbavietā, jo emigrantēm ar augstāko izglītību, kam ir grūtības "savilkt galus” un nomaksāt nepieciešamos izdevumus mītnes valstī, ir lielāka varbūtîba saskarties ar darba uzdevumu diskrimināciju, kad viṇām biežāk nekā vietējiem uzdod neizdevīgus vai nepatīkamus darbus, kā arī ar darba algas diskrimināciju. Uztvertās diskriminācijas varbūtību būtiski palielina rakstiska darba līguma neesamība, kā arī grūtības ar Latvijā iegūtās izglītības vai profesionālās kvalifikācijas atzǐšanu. Latvijas emigrantēm, kam nav rakstiska darba līguma un kas ir saskārušās ar grūtībām, ka Latvijā iegūtā izglītība vai profesionālā kvalifikācija netiek atzīta mītnes zemē, ir lielāka varbūtība izjust darba diskrimināciju vai netaisnīgu attieksmi. Būtiski uzsvērt, ka tām Latvijas emigrantēm, kas darbā izmanto iegūto izglītību vai kvalifikāciju, ir mazāka varbūtība saskarties ar darba uzdevumu un darba algas diskrimināciju. Šie pētījuma rezultāti ir nozīmīgi antidiskriminācijas politikas kontekstā, kas tiek īstenota gan nacionālā līmenī atsevišḳās valstīs, gan konkrētu uzṇēmumu līmenī. Lai mazinātu diskriminācijas situācijas, ir jāturpina izglītot par antidiskrimināciju un informēt par iespējām ziņot par diskrimināciju. Ir nepieciešama arī informācija, kur vērsties, ja darba devējs nevēlas slēgt darba līgumu. Būtiski, ka darbinieki darbavietā spēj atpazìt diskriminējošas prakses un nebaidās ziṇot par to. Îpaša uzmanība būtu jāpievērš antidiskriminācijas politikām un vadlīnijām šādās nozarēs: informācijas un komunikācijas pakalpojumi, rūpniecība un enerǵêtika, veselība un sociālā aprūpe, tirdzniecības, ēdināšanas un izmitināšanas pakalpojumi, jo tieši šajās nozarēs Latvijas emigrantes saskaras ar to, ka par līdz̄̄gu darbu saṇem mazāku atalgojumu nekā vietējie iedzīvotāji.

Aplūkojot ceturto pētniecisko jautājumu par to, kādas politikas iniciatīvas var veicināt augsti kvalificēto Latvijas emigrantu atgriešanos, galvenā uzmanība pievērsta jauno ES dalībvalstu iniciatīvām mazināt emigrācijas negatīvās sekas un sekmēt "smadzeṇu apmaiņu”, jo Ḳīnas vai Indijas pieredzes pārnese uz Latviju ir maz iespējama iedzīvotāju skaita ievērojamo atšḳirību dēḷ. Citu valstu pieredze atklāj, ka būtiskākās iniciatīvas, veicinot augsti kvalificēto emigrantu atgriešanos, ir vērstas uz jauno speciālistu un zinātnieku atbalstu un īstermiṇa piesaistǐšanu, tajā skaitā stipendijām, grantiem un finansiālu atbalstu remigrantiem, darbavietu radīšanas veicināšanu, kā arī atbalstu tīklošanās un mentoringa aktivitātēm augsti kvalificētajiem diasporas speciālistiem. Visbiežāk remigrācijas politikas un diasporas politikas ir vērstas uz universitātes līmeṇa pasniedzēju un pētnieku remigrācijas veicināšanu un jauno uzṇēmēju piesaistî̌sanu. Diemžēl ES valstu pieredze rāda, ka programmas, 
kas vērstas uz atbalstu augsti kvalificētiem speciālistiem, lielākoties ir diezgan dārgas, mazskaitlīgas, nereti tiek uzskatītas par neefektīvām un sabiedrībā tiek neviennozīmīgi vērtētas. Pozitīvāk novērtētas ir tās iniciatīvas, kas sniedz atbalstu remigrantu uzṇēmējdarbībai, jo emigranti ar uzṇēmējdarbības vai profesionālo pieredzi ārzemēs bieži vien spēj saskatīt jaunas uzṇēmējdarbības iespējas, radīt inovatīvas idejas un pārrobežu sadarbības tīklus, veicinot zināšanu un tehnoloǵiju pārnesi, un atbalstît ar savu pieredzi un zināšanām jaunus, perspektīvus uzṇēmumus.

Vairākos aspektos pastāv noteikti ierobežojumi, lai minētos pētnieciskos secinājumus varētu vispārināt. Attiecībā uz augsti kvalificēto emigrantu atgriešanos Latvijā jāuzsver, ka pētījumā veiktā analīze attiecas nevis uz augsti kvalificēto emigrantu faktisko atgriešanos, bet gan uz viṇu plāniem atgriezties. Savukārt atgriešanās plāni nenozīmē atgriešanos, bet gan tikai atgriešanās iespējamību, kas drīzāk ir atgriešanās priekšnosacījums un raksturo migrantu attieksmi pret savu migrācijas pieredzi.

Attiecībā uz emigrējušo augsti kvalificēto sieviešu diskriminācijas pieredzi jānorāda, ka ir analizētas nevis reāli novērotas diskriminācijas situācijas, bet gan subjektīvā diskriminācijas uztvere jeb uztvertā diskriminācija. Noteiktos gadījumos tā var būt arī reāla diskriminācijas pieredze, bet citos gadījumos tikai iedomāta situācija, ka, piemēram, kādam citam par to pašu darbu maksā vairāk. Šādā pētījumā nav iespējams noškiirt reālu un iedomātu diskriminācijas situāciju. Secinājumu vispārināšanu zināmā mērā ierobežo arī šādos pētījumos novērotā kauzalitātes problēma. Lai gan analīzes rezultāti parāda, ka tās Latvijas emigrantes, kas jūtas mazāk piederīgas mītnes valstij, ar lielāku varbūtību saskarsies ar uztverto diskrimināciju, nevar viennozīmīgi secināt, ka piederības sajūta mītnes valstij ietekmē uztverto diskrimināciju. Iespējams, kauzālās attiecības ir tieši pretējas, un tas, ka emigrante ar augstāko izglītību izjūt diskrimināciju, mazina viṇas piederības sajūtu uzṇemošajai valstij. Jāsecina, ka jebkādi vispārinājumi par analīzes rezultātiem ir jāizdara l̦oti piesardzīgi un secinājumu validēšanai nepieciešami turpmāki pētījumi.

Noslēgumā jāatzīmē, ka šajā grāmatā augsti kvalificētu speciālistu migrācijas fenomens ir skatīts tikai no vienas nosūtošās valsts - Latvijas - perspektīvas. Šādu pieeju raksturo metodologiiskais nacionālisms, kas samazina iespēju izstrādāt plašākas skaidrojošās teorijas un vispārinājuma pakāpi (Wimmer \& Glick Schiller, 2002). Tomēr šī pētījuma mērḳis bija izpētīt tieši augsti kvalificētu Latvijas speciālistu migrācijas tendences, un turpmākajos pētījumos iespējams aplūkot šos procesus salīdzinošā perspektīvā. 
Abella, M. (2006). Global Competition for Skilled Workers and Consequences. In: C. Kuptsch \& E. F. Pang (eds.). Competing for Global Talent. Geneva: Institute for Labour Studies, ILO, pp. 11-32.

Ackers, L. (2005). Moving People and Knowledge: Scientific Mobility in the European Union. International Migration, 43(5), pp. 99-131.

Adams, W. (ed.) (1968). The Brain Drain. New York: Macmillian Company.

Aguirre, B. E., Saenz, R., \& Hwang, S. S. (1989). Discrimination and the assimilation and ethnic competition perspectives. Social Science Quarterly, 70, pp. 1989-1996.

Aikins, K. \& White, N. (2011). Global Diaspora Strategies Toolkit. Dublin: Diaspora Matters.

Akadēmiskās informācijas centrs (2016). Informācija par ārvalstīs iegūtu izglītības dokumentu akadēmisko atzī̌sanu Latvijā. Pieejams: http://www.aic.lv/portal/ arvalstu-diplomu-atzisana/arvalstis-iegutu-izglitibas-dokumentu-akademiskaatzisana-latvija

Apsite, E. (2011a). Occupational changes: Latvian migrants in the UK and Sweden. Human resources - the main factor of regional development, No. 5, pp. 27-32.

Apsite, E. (2011b). Will they return? Latvian imigrants in the United Kingdom. In: T. Muravska (ed.). European Integration and Baltic Sea Region: Diversity and Perspectives. Riga: The University of Latvia Press, pp. 11-25. 
Apsite, E., Lundholm, E., \& Stjernstrorn, O. (2012). Baltic State migration system: The case of Latvian immigrants in Sweden. The Journal of Nordic Studies, 6(1), pp. 31-51.

Apsīte-Beriṇa, E. (2013). Starpvalstu migrācija Eiropas Savienībā: Latvijas iedzīvotāju migrācija uz Lielbritāniju. Promocijas darbs ǵeogrāfijas doktora zinātniskā grāda iegūšanai. Latvijas Universitāte: Ģeogrāfijas un Zemes zinātṇu fakultāte.

Ariss, A. A. \& Jawad, S. (2011). Capital Mobilization of Skilled Migrants: A Relational Perspective. British Journal of Management, 22, pp. 286-304.

Arslan, C., Dumont, J.-C., Kone, Z., Moullan, Y., Ozden, C., Parsons, C., \& Xenogiani, T. (2014). A new profile of migrants in the aftermath of the recent economic crisis. OECD Social, Employment and Migration Working Papers No. 160. OECD Publishing.

Ārlietu ministrija (2013). Informatīvais ziņojums par Ārlietu ministrijas sadarbību ar Latvijas diasporu 2013.-2015. gadā. Pieejams: http://www.mfa.gov.lv/data/file/ aminfo_040213.pdf

Ārlietu ministrija (2020). Notiks Diasporas konsultatīvās padomes sēde. Pieejams: https://lvportals.lv/dienaskartiba/316862-notiks-diasporas-konsultativas-padomes-sede-2020

Bailey, A. \& Mulder, C. H. (2017). Highly Skilled Migration Between the Global North and South: Gender, Life Courses and Institutions. Journal of Ethnic and Migration Studies, 43(16), pp. 2689-2703. doi: 10.1080/1369183X.2017.1314594.

Barcevičius, E. (2015). How successful are highly qualified return migrants in the Lithuanian labour market? International Migration, 54(3), pp. 35-47.

Bauder, H. (2003). "Brain Abuse”, or the Devaluation of Immigrant Labour in Canada. Antipode, 35(4), pp. 699-717.

Bauder, H. (2005a). Institutional Capital and Labour Devaluation: The Non Recognition of Foreign Credentials in Germany. Intervention: Zeitschrift für Ökonomie. Journal of Economics, 2(1), pp. 75-93.

Bauder, H. (2005b). Habitus, rules of the labour market and employment strategies of immigrants in Vancouver, Canada. Social and Cultural Geography, 6(1), pp. 81-97.

Beaverstock, J. V. \& Boardwell, J. T. (2000). Negotiating globalisation, transnational corporations and global cities financial centres in transient migration studies. Applied Geography, 20(3), pp. 277-304.

Beaverstock, J. V. \& Smith, J. (1996). Lending Jobs to Global Cities: Skilled International Labor Migration, Investment Banking and the City of London. Urban studies, 33, pp. 1377-1394.

Beaverstock, J. V. (1990). New International Labor-Markets: The Case of Professional and Managerial Labor Migration Within Large Chartered Accountancy Firms. Area, 2, pp. 151-158. 
Beaverstock, J. V. (1994). Rethinking Skilled International Labor Migration: World Cities and Banking Organizations. Geoforum, 25, pp. 323-338.

Beaverstock, J. V. (1996). Revisiting High-Waged Labor-Market Demand in the Global Cities: British Professional and Managerial Workers in New-York-City. International Journal of Urban and Regional Research, 20, pp. 422-445.

Becker, G. (1993) [1964]. Human capital: a theoretical and empirical analysis, with special reference to education. 3rd ed. Chicago: The University of Chicago Press.

Beech, S. (2017). Adapting to Change in the Higher Education System: International Student Mobility as a Migration Industry. Journal of Ethnic and Migration Studies, 44(4), pp. 610-625.

Bharte, U. L. \& Sharma, R. (2014). Diasporic Paths to Development: An Indian Perspective. In: G. Tejada, U. Bhattacharya, B. Khadria, \& C. Kuptsch (eds.). Indian Skilled Migration and Development: To Europe and Back. Springer, pp. 160-184.

Black, R., Engbersen, G., Okólski, M., \& Panţîru, C. (2010). A continent moving west? EU enlargement and labour migration from Central and Eastern Europe. IMISCOE Research Series. Amsterdam: Amsterdam University Press.

Boneva, B. S. \& Frieze, I. H. (2001). Toward a concept of a migrant personality. Journal of Social Issues, 57(3), pp. 477-491.

Borjas, G. J. \& Bratsberg, B. (1996). Who Leaves? The Outmigration of the Foreign-Born. The Review of Economics and Statistics, 78 (1), pp. 165-176. doi: $10.2307 / 2109856$.

Boros, L. \& Hegedüs, G. (2016). European National Policies Aimed at Stimulating Return Migration. In: R. Nadler, Z. Kovács, B. Glorius, \& T. Lang (eds.). Return Migration and Regional Development in Europe. Mobility Against the Stream. New Geographies of Europe. Palgrave Macmillan, pp. 333-357.

Boucher, A. \& Cerna, L. (2014). Current Policy Trends in Skilled Immigration Policy. International Migration, 52(3), pp. 21-25. doi: 10.1111/imig.12152.

Bourdieu, P. (1984). Distinction. A Social Critique of the Judgement of Taste. Cambridge M.A: Harvard University Press.

Bourdieu, P. (1986). The Forms of Capital. In: J. G. Richardson. Handbook for Theory and Research for the Sociology of Education. New York: Greenwood, pp. 241-258.

Bree, J. de, Davids, T., \& Haas, H. de (2010). Post-return experiences and transnational belonging of return migrants: a Dutch-Moroccan case study. Global Networks - A Journal of Transnational Affairs, 10(4), pp. 489-509. doi: 10.1111/j.1471-0374.2010.00299.x.

Brettell, B. C. \& Hollifield, F. J. (2015). Introduction. Migration Theory. Talking across Disciplines. In: Migration Theory: Talking across Disciplines. Ed. by B. C. Brettell \& F. J. Hollifield. 3rd ed. Routledge, pp. 1-36.

Brettell, B. C. (2015). Theorizing Migration in Anthropology. The Cultural, Social, and Phenomenological Dimensions of Movement. In: Migration Theory: Talking 
across Disciplines. Ed. by B. C. Brettell \& F. J. Hollifield. 3rd ed. Routledge, pp. 148-197.

Brüss, J. (2008). Experiences of discrimination reported by Turkish, Moroccan and Bangladeshi Muslims in three European cities. Journal of Ethnic and Migration Studies, 34(6), pp. 875-894. doi: 10.1080/13691830802211166.

Bundesanstalt für Arbeit (Ed.) (2000). Arbeitsmarkt in Zahlen. Arbeitsgenehmigungen 2000. Jahreszahlen, Bundesanstalt fur Arbeit, Nürnberg.

Bury, M. (1982). Chronic illness as biographical disruption. Sociology of Health \& Illness, 4(2), pp. 167-182.

Cairns, D., Growiec, K., \& Smyth, J. (2013). Leaving Northern Ireland: youth mobility, field, habitus and recession among undergraduates in Belfast. British Journal of sociology of Education, 34(4), pp. 544-562.

Carling, J. \& Erdal, M. B. (2014). Return Migration and Transnationalism: How Are the Two Connected? Intenational Migration, 52, pp. 2-12. doi: 10.1111/ imig. 12180.

Carling, J. \& Hoelscher, K. (2013). The Capacity and Desire to Remit: Comparing Local and Transnational Influences. Journal of Ethnic and Migration Studies, 39(6), pp. 939-958. doi: 10.1080/1369183X.2013.765657.

Carling, J. \& Pettersen, S. V. (2014). Return Migration Intentions in the IntegrationTransnationalism Matrix. International Migration, 52(6), pp. 13-30. doi: 10.1111/ imig. 12161.

Cassarino, J.-P. (2004). Theorising return migration: the conceptual approach to return migration revisited. International Journal on Multicultural Societies, 6(2), pp. 253-279.

Cerna, L. (2010). Policies and practices of highly skilled migration in times of the economic crisis. International Migration Papers No. 99.

Cerna, L. (2011). Selecting the Best and the Brightest. Oxford: Policy Primer, University of Oxford.

Chernilo, D. (2011). The critique of methodological nationalism: Theory and history. Thesis Eleven, 106(1), pp. 98-117.

Clark, W. A. V. (2013). Life Course Events and Residential Change: Unpacking Age Effects on the Probability of Moving. Journal of Population Research, 30(4), pp. 319-334.

Constant, A. \& Massey, D. S. (2002). Return Migration by German Guestworkers: Neoclassical Versus New Economic Theories. International Migration, 40(4), pp. 5-38. doi: 10.1111/1468-2435.00204.

Cranston, S., Schapendonk, J., \& Spaan, E. (2018). New Directions in Exploring the Migration Industries: Introduction to Special Issue. Journal of Ethnic and Migration Studies, 44(4), pp. 543-557.

Crawford, T. (1973). Beliefs About Birth Control: A Consistency Theory Analysis. Representative Research in Social Psychology, 4, pp. 53-65.

Create Lithuania (2020). About the Programme. Available: http://kurklt.lt/en/ 
Csedö, K. (2008). Negotiating Skills in the Global City: Hungarian and Romanian Professionals and Graduates in London. Journal of Ethnic and Migration Studies, 34(5), pp. 803-823.

CSP (2020a). IBG020. Starptautiskā ilgtermiņa migrācija pa valstu grupām. Pieejams: http://data1.csb.gov.lv/pxweb/lv/iedz/iedz__migr/IBG020.px/?rxid=fd7c1a0db6fd-453b-ade1-f084b148d3c3

CSP (2020b). IBG041. Starptautisko ilgtermiņa migrantu etniskais sastāvs. Pieejams: http://data1.csb.gov.lv/pxweb/lv/iedz/iedz__migr/IBG041.px/

CSP (2020c). IBG200. Remigrantus raksturojošie rādītāji. Pieejams: http://data.csb. gov.lv/pxweb/lv/iedz/iedz_migr/IBG200.px/

Damušis, G. (2014). Diaspora policy in Lithuania: building bridges and new connections. 2nd Baltic Round Table. Available: http://www.sirius-migrationeducation.org/wp-content/uploads/2014/12/Ginte-Damusis_Global-Lithuania-Strategy_2nd-Baltic-Round-Table_03-11-14.pdf

Diasporas likums (2018). Latvijas Vēstnesis, 225, 14.11.2018. Pieejams: https://likumi.lv/ta/id/302998-diasporas-likums

Dustmann, C. (2000). Temporary Migration and Economic Assimilation. Swedish Economic Policy Review, 7, pp. 213-244.

Dustmann, C. (2003). Return Migration, Wage Differentials, and the Optimal Migration Duration. European Economic Review, 47(2), pp. 353-367. doi: 10.1016/ S0014-2921(01)00184-2.

Dzenovska, D. (2015). 'Know your diaspora!': Knowledge production and governing capacity in the context of Latvian diaspora politics. In: N. Sigona, A. Gamlen, G. Liberatore, H. Neveu Kringelbach, V. Ivanova, \& I. Zwania-Roessler (eds.). Diasporas Reimagined: Spaces, Practices and Belonging. Oxford: Oxford Diasporas Programme, pp. 190-193.

Ekonomikas ministrija (2017). Informatīvais ziņojums par Reemigrācijas atbalsta pasākumu plāna 2013.-2016. gadam izpildi. Pieejams: https://www.em.gov.lv/ files/nozares_politika/EMzin_060417_reemigr.docx

Elder, G. H., Kirkpatrick Johnson, M., \& Crosnoe, R. (2003). The Emergence and Development of Life Course Theory. In: J. T. Mortimer \& M. J. Shanahan (eds.). Handbook of the Life Course. Springer, pp. 3-19.

Engbersen, G. \& Jansen, J. (2013). Emigration from the Baltic States: Economic Impact and Policy Implications. In: Coping with Emigration in Baltic and East European Countries. OECD, pp. 13-27. doi: 10.1787/9789264204928-en.

Engbersen, G. \& Snel, E. (2013). Liquid migration. Dynamic and fluid patterns of post-accession migration flows. In: B. Glorius, I. Grabowska-Lusinska, \& A. Kuvik (eds.). Mobility in Transition: Migration Patterns after EU Enlargement. IMISCOE Research Series. Amsterdam: Amsterdam University Press, pp. 21-40.

Engbersen, G., Snel, E., \& Boom, J. de (2010). A Van Full of Poles: Liquid Migration in Eastern and Central European Countries. In: A Continent Moving West? EU 
Enlargement and Labour Migration from Central and Eastern Europe. Ed. by R. Black, G. Engbersen, M. Okólski, \& C. Pantîru. Amsterdam: Amsterdam University Press, pp. 115-140.

Erel, U. (2007). Constructing Meaningful Lives: Biographical Methods in Research on Migrant Women. Sociological Research Online, 12(4). Available: http://www. socresonline.org.uk/12/4/5.html

Erel, U. (2010). Migrating Cultural Capital: Bourdieu in Migration Studies. Sociology, 44(4), pp. 642-660. doi: 10.1177/0038038510369363.

Estrada, E. P., Tsai, Y. M., \& Chandler, C. R. (2008). Assimilation and discriminatory perceptions and experiences: The case of Hispanics in the United States. The Social Science Journal, 45(4), pp. 673-681. doi: 10.1016/j.soscij.2008.09.013.

Eurostat (2019). EU Citizens Living in Another Member State - Statistical Overview. Available: https://ec.europa.eu/eurostat/statistics-explained/index.php?title=EU_ citizens_living_in_another_Member_State_-_statistical_overview\#Who_are_ the_most_mobile_EU_citizens.3F

Faist, T. (1997). The crucial meso-level. In: T. Hammar, G. Brochmann, K. Tamas, \& T. Faist (eds.). International Migration, Immobility and Development: Multidisciplinary Perspectives. Oxford: Berg, pp. 187-217.

Faist, T. (1998). Transnational social spaces out of international migration: Evolution, significance and future prospects. European Journal of Sociology, 39(2), pp. 213-247.

Favell, A. (2008). The New Face of East-West Migration in Europe. Journal of Ethnic and Migration Studies, 34(5), pp. 701-716.

Ferrant, G. \& Tuccio, M. (2015). South-South Migration and Discrimination Against Women in Social Institutions: A Two-way Relationship. World Development, 72, pp. 240-254. doi: 10.1016/j.worlddev.2015.03.002.

Ferro, A. (2004). Romanians abroad: a snapshot of highly skilled migration. Higher Education in Europe, 29(3), pp. 381-392.

Findlay, A. \& Gould, W. T. S. (1989). Skilled International Migration: a Research Agenda. Area, 21, pp. 3-11.

Findlay, A. (1990). A Migration Channels Approach to the Study of High-Level Manpower Movements: A Theoretical Perspective. International Migration, 28, pp. 15-23.

Findlay, A. M. \& Garrick, L. (1990). Scottish Emigration in the 1980s: a Migration Channels Approach to the Study of Skilled International Migration. Transactions of the Institute of British Geographers (NS), 15, pp. 177-192.

Findlay, A. M. \& Li, F. L. N. (1998). A Migration Channels Approach to the Study of Professionals Moving to and from Hong Kong. International Migration Review, 32, pp. 682-703.

Findlay, A. M. (1988). From Settlers to Skilled Transients: The Changing Structure of British International Migration. Geoforum, 19, pp. 401-410. 
Findlay, A. M. (1995). Skilled Transients: The Invisible Phenomenon? In: The Cambridge Survey of World Migration. Ed. by R. Cohen. Cambridge: Cambridge University Press, pp. 515-522.

Findlay, A., McCollum, D., Shubin, S., Apsite, E., \& Krisjane, Z. (2013). The role of recruitment agencies in imagining and producing the 'good' migrant. Social \& Cultural Geography, 14(2), pp. 145-167.

Fitzgerald, D. (2000). Negotiating Extra-Territorial Citizenship: Mexican Migration and the Transnational Politics of Community. San Diego: Center for Comparative Immigration Studies, University of California.

Fortney, J. A. (1970). International Migration of Professionals. Population Studies, 24, pp. 217-235.

Foster, A. D. \& Rosenzweig, M. R. (2001). Imperfect Commitment, Altruism, and the Family: Evidence from Transfer Behaviour in Low-Income Rural Areas. The Review of Economics and Statistics, 83(3), pp. 389-407.

Franses, P. H. (2015). Return migration of high skilled workers: The case of Suriname. Econometric Institute Report 2015-03. Rotterdam: Erasmus School of Economics.

Freeman, R. (2006). People Flows in Globalization. NBER Working Paper No. 12315. Cambridge, MA: National Bureau of Economic Research.

Friedberg, R. M. (2000). You can't take it with you? Immigrant assimilation and the portability of human capital. Journal of Labor Economics, 18(2), pp. 221-251.

Fussell, E. (2012). Space, Time, and Volition; Dimensions of Migration Theory. In: M. R. Rosenblum \& D. J. Tichenor (eds.). The Oxford Handbook of the Politics of International Migration. Oxford: Oxford University Press, pp. 25-52.

Gabaccia, D. R. (2015). Time and Temporality in Migration Studies. In: Migration Theory: Talking across Disciplines. Ed. by B. C. Brettell \& F. J. Hollifield. 3rd ed. Routledge, pp. 37-66.

Gamlen, A. (2006). Diaspora Engagement Policies: What are They, and What Kind of States Use Them? Working Paper No. 32. University of Oxford, COMPAS (Centre on Migration, Policy and Society).

Geddie, K. (2013). The Transnational Ties That Bind: Relationship Considerations for Graduating International Science and Engineering Research Students. Population, Space and Place, 19(2), pp. 196-208.

Gibson, J. \& McKenzie, D. (2009). The Microeconomic Determinants of Emigration and Return Migration of the Best and the Brightest: Evidence from the Pacific. IZA discussion paper (Vol. 3926). Bonn: Institute for the Study of Labor (IZA).

Glick Schiller, N., Basch, L., \& Blanc-Szanton, C. (1992). Transnationalism: A New Analytic Framework for Understanding Migration. Annals of the New York Academy of Sciences, 645, pp. 1-24. doi: 10.1111/j.1749-6632.1992.tb33484.x.

Glorious, B. (2013). Understanding the counter-flow: Theoretical and methodological aspects in studying remigration processes after EU expansion. In: B. Glorius, I. Grabowska-Lusinska, \& A. Kuvik (eds.). Mobility in Transition: Migration 
Patterns after EU Enlargement. IMISCOE Research Series. Amsterdam: Amsterdam University Press, pp. 217-236.

Glorius, B., Grabowska-Lusinska, I., \& Kuvik, A. (2013). Mobility in Transition: Migration Patterns after EU Enlargement. IMISCOE Research Series. Amsterdam: Amsterdam University Press.

Göler, D., Krišjāne, Z., \& Bērziņš, M. (2014). International Migration in the Periods of Transition and Crisis: the Case of Latvia. The Baltic Region Issue, 2(20), pp. 97-110.

Gordon, M. (1964). Assimilation in American Life. The Role of Race, Religion, and National Origins. New York: Oxford University Press.

Goss, J. \& Lindquist, B. (1995). Conceptualizing International Labour Migration: A Structuration Perspective. International Migration Review, 29(2), pp. 317-351.

Grabowska, I. (2016). Migration in Working Lives: Looking Back after Return; a Structure and Agency Approach. In: R. Nadler, Z. Kovics, B. Glorius, \& T. Lang (eds.). Return Migration and Regional Development in Europe: Mobility Against the Stream. Palgrave Macmillan, pp. 83-109.

Grigoleit-Richter, G. (2017). Highly skilled and highly mobile? Examining gendered and ethnicised labour market conditions for migrant women in STEM professions in Germany. Journal of Ethnic and Migration Studies, 43(16), pp. 2738-2755. doi: 10.1080/1369183X.2017.1314597.

Gudelis, D. \& Klimavičiūtè, L. (2016). Assessing “Global Lithuania”: the strengths and weaknesses of Lithuanian diaspora engagement strategy. Journal of Baltic Studies, 47(3), pp. 1-24.

Guilmoto, C. Z. \& Sandron, F. (2001). The Internal Dynamics of Migration Networks in Developing Countries. Population: An English Selection, 13(2), pp. 135-164.

Güngör, N. D. \& Tansel, A. (2008). Brain Drain from Turkey: An Investigation of Students’ Return Intentions. Applied Economics, 40(23), pp. 3069-3087. doi: 10.1080/00036840600993999.

Guth, J. \& Gill, B. (2008). Motivations in East-West Doctoral Mobility: Revisiting the Question of Brain Drain. Journal of Ethnic and Migration Studies, 34(5), pp. 825-841.

Haas, H. de \& Fokkema, T. (2011). The Effects of Integration and Transnational Ties on International Return Migration Intentions. Demographic Research, 25, pp. 755-782. doi: 10.4054/DemRes.2011.25.24.

Haas, H. de (2006). Engaging diasporas. How governments and development agencies can support diasporas involvement in the development of origin countries. A study for Oxfam Novib. Oxford: University of Oxford, International Migration Institute.

Haas, H. de (2010). Migration and development: A theoretical perspective. International Migration Review, 44(1), pp. 227-264. 
Haas, H. de, Fokkema, T., \& Fihri, M. F. (2015). Return Migration as Failure or Success? The Determinants of Return Migration Intentions Among Moroccan Migrants in Europe. Journal of International Migration and Integration, 16(2), pp. 415-429. doi: 10.1007/s12134-014-0344-6.

Hagen-Zanker, J. (2008). Why do people migrate? A review of the theoretical literature. Working Paper. Maastricht Graduate School of Governance. Available: https:// mpra.ub.uni-muenchen.de/28197/1/2008WP002

Halaby, C. N. (1986). Worker attachment and workplace authority. American Sociological Review, 51(5), pp. 634-649. doi: 10.2307/2095489.

Hardwick, W. S. (2015). Coming of Age. Migration Theory in Geography. In: Migration Theory: Talking across Disciplines. Ed. by B. C. Brettell \& F. J. Hollifield. 3rd ed. Routledge, pp. 198-226.

Harvey, W. S. (2008). Strong or Weak Ties? British and Indian Expatriate Scientists Finding Jobs in Boston. Global Networks, 8(4), pp. 453-473.

Hazans, M. (2011). Latvijas emigrācijas mainīgā seja: 2000-2010. Grām.: B. Zepa, E. Kḷave (red.). Latvija. Pārskats par tautas attīstību. 2010/2011. Nacionālā identitāte, mobilitāte un rīcībspēja. Rīga: LU Sociālo un politisko pētījumu institūts, 70.-91. lpp.

Hazans, M. (2015). Smadzeṇu aizplūde no Latvijas 21. gadsimtā. Grām.: Latvijas emigrantu kopienas: cerību diaspora. Red. I. Mieriṇa. Rīga: Latvijas Universitāte, 85.-92. lpp.

Hazans, M. (2016). Atgriešanās Latvijā. Remigrantu aptaujas rezultāti. Rīga: Latvijas Universitātes Diasporas un migrācijas pētījumu centrs.

Hazans, M. (2017). Labour Mobility: Challenge or Chance? Evidence from the Baltics and Poland in the 21st century. Presentation. Baltic Sea Labour Forum Round Table. Berlin, Germany: Council of the Baltic Sea States. doi: 10.13140/ RG.2.2.20156.54409.

Hazans, M. (2018). An in-depth analysis of the emigration of skilled labour. Latvia. Brussels: European Centre of Expertise in the field of labour law, employment and labour market policy. Available: https://ec.europa.eu/social/main. jsp?catId=738\&langId=en\&pubId=8132\&furtherPubs=yes

Hazans, M. (2019). Emigration from Latvia: A Brief History and Driving Forces in the Twenty-First Century. In: The Emigrant Communities of Latvia: National Identity, Transnational Belonging, and Diaspora Politics. Ed. by R. Kaša \& I. Mieriņa. Springer Open, pp. 35-68.

Hercog, M. \& Siddiqui, M. Z. (2014). Experiences in the Host Countries and Return Plans: The Case Study of Highly Skilled Indians in Europe. In: G. Tejada, U. Bhattacharya, B. Khadria, \& C. Kuptsch (eds.). Indian Skilled Migration and Development. To Europe and Back. New Delhi: Springer India, pp. 213-235. doi: 10.1007/978-81-322-1810-4_9. 
Hooper, K. \& Sumption, M. (2016). Reaching a "Fair Deal” on Talent: Emigration, Circulation, and Human Capital in Countries of Origin. Washington, DC: Migration Policy Institute.

Hsinchu Science Park (2018). Available: https://www.sipa.gov.tw/english/index.jsp

ICF (2018). Study on the Movement of Skilled Labour. Luxembourg: Publications Office of the European Union.

IOM/OECD (2014). Harnessing Knowledge on the Migration of Highly Skilled Women. Geneva: International Organization for Migration.

Irish Technology Leadership Group (2018). Available: http://www.itlg.org/

Izglītības un zinātnes ministrija (2017). Latvijas augstskolas un zinātniskie institūti gatavo vērienīgus STEM studiju programmu modernizācijas un pētniecības infrastruktūras attīstības projektus. 04.05.2017. Pieejams: https://www.izm.gov.lv/ lv/aktualitates/2355-latvijas-augstskolas-un-zinatniskie-instituti-gatavo-verienigus-stem-studiju-programmu-modernizacijas-un-petniecibas-infrastrukturas-attistibas-projektus

Jong, G. F. de (2000). Expectations, Gender, and Norms in Migration Decision-Making. Population Studies, 54(3), pp. 307-319. doi: 10.1080/713779089.

Kaczmarczyk, P. \& Lesińska, M. (2013). Return migration, state policy and integration of returnees - the Case of Poland. In: V. Ivanova \& I. Zwania-Roessler (eds.). Welcome Home? Challenges and Chances of Return Migration. Transatlantic Forum on Migration and Integration. Sofia: Maria Arabadjieva Printing House, pp. 29-34.

Kelly, P. \& Lusis, T. (2006). Migration and the Transnational Habitus: Evidence from Canada and the Philippines. Environment and Planning A: Economy and Space, 38(5), pp. 831-847. doi: 10.1068/a37214.

Khadria, B. (2014). The Dichotomy of the Skilled and Unskilled Among Non-resident Indians and Persons of Indian Origin: Bane or Boon for Development in India? In: G. Tejada, U. Bhattacharya, B. Khadria, \& C. Kuptsch (eds.). Indian Skilled Migration and Development: To Europe and Back. Springer, pp. 29-46.

Kilkey, M. \& Palenga-Möllenbeck, E. (2016). Introduction: Family Life in an Age of Migration and Mobility: Introducing a Global and Family Life-Course Perspective. In: M. Kilkey \& E. Palenga-Möllenbeck (eds.). Family Life in an Age of Migration and Mobility. Migration, Diasporas and Citizenship.

King, R. \& Lulle, A. (2016). Grandmothers migrating, working and caring: Latvian women between survival and self-realisation. Population Horizons, 13(2), pp. 4353. doi: 10.1515/pophzn-2016-0003.

King, R. (2000). Generalizations from the history of return migration. In: B. Ghosh (ed.). Return migration: Journey of hope or despair? Geneva: International Organization for Migration and the United Nations, pp. 7-55.

King, R., Lulle, A., Conti, F., Mueller, D., \& Scotto, G. (2014). The lure of London: A comparative study of recent graduate migration from Germany, Italy and Latvia. Sussex Centre for Migration Research, Working Paper No. 75 07/2014. 
King, R., Lulle, A., \& Buzinska, L. (2016). Beyond remittances: knowledge transfer among highly educated Latvian youth abroad. Sociology of Development, 2(2), pp. 183-203.

King, R., Lulle, A., Conti, F., \& Mueller, D. (2016a). Eurocity London: a qualitative comparison of graduate migration from Germany, Italy and Latvia. Comparative Migration Studies, 4. a3.

King, R., Lulle, A., Morosanu, L., \& Williams, A. (2016b). International youth mobility and life transitions in Europe: questions, definitions, typologies and theoretical approaches. Working Paper. Sussex Centre for Migration Research. Available: http://sro.sussex.ac.uk/61441/1/mwp86.pdf

King, R., Lulle, A., Parutis, V., \& Saar, M. (2015). Young Baltic graduates living and working in London: from peripheral region to escalator region in Europe. Working Paper. Brighton: University of Sussex. Available: http://sro.sussex.ac.uk/68060/1/ mwp82.pdf

King, R., Lulle, A., Parutis, V., \& Saar, M. (2017). From peripheral region to escalator region in Europe: young Baltic graduates in London. European Urban and Regional Studies. doi: 10.1177/0969776417702690.

Kirk, K., Bal, E., \& Janssen, S. R. (2017). Migrants in liminal time and space: an exploration of the experiences of highly skilled Indian bachelors in Amsterdam. Journal of Ethnic and Migration Studies, 43(16), pp. 2771-2787. doi: 10.1080/1369183X.2017.1314600.

Kivisto, P. (2001). Theorizing Transnational Immigration: A Critical Review of Current Efforts. Ethnic and Racial Studies, 24(4), pp. 549-577. doi: 10.1080/ 01419870120049789.

Klagge, B. \& Klein-Hitpaß, K. (2008). High-skilled return migration and knowledgebased economic development in regional perspective. Conceptual considerations and the example of Poland. Warsaw: Centre of Migration Research, Warsaw University.

Klein-Hitpaß, K. (2016). Return Migrants as Knowledge Brokers and Institutional Innovators: New Theoretical Conceptualisations and the Example of Poland. In: R. Nadler, Z. Koviccs, B. Glorius, \& T. Lang (eds.). Return Migration and Regional Development in Europe: Mobility Against the Stream. Palgrave Macmillan, pp. 55-81.

Kḷave, E. \& Šūpule, I. (2017). Latvian and Language Competition in the Diaspora (Emigrant Community). In: G. Kḷava (ed.). Language situation in Latvia: 20102015: A sociolinguistic study. Rīga: Latviešu valodas aǵentūra, pp. 123-155.

Kḷave, E. \& Šūpule, I. (2019). Return Migration Process in Policy and Practice. In: The Emigrant Communities of Latvia: National Identity, Transnational Belonging, and Diaspora Politics. Ed. by R. Kaša, I. Mierin̦a. Springer Open, pp. 261-282. Kḷave, E., Šūpule, I. (2015). Reemigrācijas politika Latvijā: politika un prakse. Grām.: Latvijas emigrantu kopienas: cerību diaspora. Red. I. Mieriṇa. Rīga: Latvijas Universitāte, 194.-209. lpp. 
Kofman, E. (2014). Towards a gendered evaluation of (highly) skilled immigration policies in Europe. International Migration, 52(3), pp. 116-128. doi: 10.1111/ imig.12121.

Koikkalainen, S. (2013). Making it abroad. Experiences of highly skilled Finns in European Union labour market. Rovaniemi: University of Lapland Printing Centre.

Koser, K. \& Salt, J. (1997). The geography of highly skilled international migration. International Journal of Population Geography, 3(4), pp. 285-304.

Kõu, A., Mulder, C. H., \& Bailey, A. (2017). 'For the sake of the family and future': the linked lives of highly skilled Indian migrants. Journal of Ethnic and Migration Studies, 43:16, pp. 2788-2805.

Kõu, A., Wissen, L. van, Dijk, J. van, \& Bailey, A. (2015). A Life Course Approach to High-skilled Migration: Lived Experiences of Indians in the Netherlands. Journal of Ethnic and Migration Studies, 41(10), pp. 1644-1663.

Kovács, Z., Boros, L., Hegedüs, G., \& Lados, G. (2013). Returning people to the homeland: Tools and methods supporting remigrants in a European context. In: T. Lang (ed.). Return migration in Central Europe: Current trends and an analysis of policies supporting returning migrants. Leipzig: Leibniz Institute for Regional Geography, pp. 58-94.

Krisjane, Z., Apsite-Berina, E., \& Berzins, M. (2016). Circularity within the EU: the return intentions of Latvian migrants. In: R. Nadler, Z. Kovács, B. Glorius, \& T. Lang (eds.). Return Migration and Regional Development in Europe: Mobility Against the Stream. Palgrave Macmillan, pp. 215-240.

Krisjane, Z., Berzins, M., \& Apsite, E. (2013). Post-accession migration from the Baltic States. The case of Latvia. In: B. Glorius, I. Grabowska-Lusinska, A. Kuvik (eds.). Mobility in Transition: Migration Patterns after EU Enlargement. IMISCOE Research Series. Amsterdam: Amsterdam University Press, pp. 85-111.

Kuvik, A. (2012). Skilled migration in Europe and beyond: Recent developments and theoretical considerations. In: An introduction to international migration studies: European perspectives. Ed. by M. Martiniello \& J. Rath. Amsterdam: Amsterdam University Press, pp. 211-235.

Lang, T., Glorius, B., Nadler, R., \& Kovács, Z. (2016). Introduction: Mobility Against the Stream? New Concepts, Methodological Approaches and Regional Perspectives on Return Migration in Europe. In: R. Nadler, Z. Kovács, B. Glorius, \& T. Lang (eds.). Return Migration and Regional Development in Europe: Mobility Against the Stream. Palgrave Macmillan, pp. 1-22.

Latvijas Nacionālais attīstības plāns 2014.-2020. gadam (2012). Pieejams: http://polsis.mk.gov.lv/view.do?id=4247

LĀZA (2016). Izveidota medicīnas darbinieku atbalsta grupa. Pieejams: http://www. lazariga.lv/60-izveidota-medicinas-darbinieku-atbalsta-grupa

Lee, E. (1966). A Theory of Migration. Demography, 3(1), pp. 47-57.

LETA (2012). Aizbraukušos latviešus mājās aicinās ar jaunu interneta vietni. Pārpublicēts portālā “Delfi”. 20.09.2012. Pieejams: http://www.delfi.lv/news/ 
national/politics/aizbraukusos-latviesus-majas-aicinas-ar-jaunu-interneta-vietni. d?id $=42686398$

Leung, M. (2001). Get IT going: New ethnic Chinese business: A case of Taiwanese-owned computer firms in Hamburg. Journal of Ethnic and Migration Studies, 27(2), pp. 277-294.

Levitt, P. \& Glick Schiller, N. (2004). Conceptualizing Simultaneity: A Transnational Social Field Perspective on Society. International Migration Review, 38(3), pp. 1002-1039. doi: 10.1111/j.1747-7379.2004.tb00227.x.

Liversage, L. (2009). Finding a Path: Investigating the Labour Market Trajectories of High-Skilled Immigrants in Denmark. Journal of Ethnic and Migration Studies, 35(2), pp. 203-226.

Līguma par Eiropas Savienības darbību konsolidētā versija (2012). Eiropas Savienības Oficiālais Vēstnesis, C 326, 26.10.2012.

Lochhead, C. (2003). The transition penalty: Unemployment among recent immigrants to Canada. Ottawa: Canadian Labour and Business Centre.

Lowell, L. B. (2002). Policy responses to the international mobility of skilled labour. Geneva, Switzerland: International Migration Branch, International Labour Office.

Lowell, L. B. (2007). Trends in International Migration Flows and Stocks, 19752005. OECD: OECD Social, Employment and Migration Working Papers No. 58. doi: $10.1787 / 063461607124$.

192 Lulle, A. \& King, R. (2016a). Ageing, Gender, and Labour Migration. Mobility \& Politics. New York: Palgrave Macmillan.

Lulle, A. \& King, R. (2016b). Ageing well: the time-spaces of possibility for older female Latvian migrants in the UK. Social and Cultural Geography, 17(3), pp. 444462. doi: 10.1080/14649365.2015.1089584.

Lulle, A. \& Buzinska, L. (2017). Between a 'student abroad' and 'being from Latvia': inequalities of access, prestige, and foreign-earned cultural capital. Journal of Ethnic and Migration Studies, 43(8), pp. 1362-1378.

Lulle, A. (2005). Eiropeizācija augsti kvalificēta darbaspēka imigrācijā Latvijā. Grām.: Ž. Ozoliṇa, T. Tisenkopfs (red.). Latvija eiropeizācijas krustcelēs. Sociālo un politisko pētījumu institūts. Rīga: Latvijas Universitāte, 71.-92. lpp.

Lulle, A. (2007). Sociālo tīklu teorijas migrācijas modeḷu skaidrojumam. Grām.: P. Zvidriṇš (red.). Paaudžu nomaiņa un migrācija Latvijā. Rīga: Zinātne, 161.179. lpp.

Lulle, A. (2014). Translokālā geoogrāfiskā mobilitāte no Latvijas Gērnsijā. Promocijas darbs ǵeogrāfijas doktora zinātniskā grāda iegūšanai. Latvijas Universitāte: G̣eogrāfijas un Zemes zinātṇu fakultāte.

Lulle, A. (2018). Relational ageing: on intra-gender and generational dynamism amongst ageing Latvian women. Area, 50(4), pp. 452-458. doi: 10.1111/ area. 12427.

Mabogunje, A. L. (1970). Systems Approach to a Theory of Rural-Urban Migration. Geographical Analysis, 2, pp. 1-18. 
Makina, M. (2012). Determinants of Return Migration Intentions: Evidence from Zimbabwean Migrants Living in South Africa. Development Southern Africa, 29(3), pp. 365-378. doi: 10.1080/0376835X.2012.706034.

Mandelbaum, D. G. (1973). The study of life history: Gandhi. Current Anthropology, 14(3), pp. 177-206. Available: http://escholarship.org/uc/item/4105081f

Massey, D. S. (1990). Social Structure, Household Strategies, and the Cumulative Causation of Migration. Population Index, 56(1), pp. 3-26.

Massey, D. S., Arango, J., Hugo, G., Kouaouci, A., Pellegrino, A., \& Taylor, J. E. (1993). Theories of international migration: a review and appraisal. Population and Development Review, 19(3), pp. 431-466.

Massey, D. S., Arango, J., Hugo, G., Kouaouci, A., Pellegrino, A. \& Taylor, J. E. (1998). Worlds in Motion: Understanding International Migration at the End of the Millennium. New York: Oxford University Press.

McCollum, D. \& Findlay, A. (2012). East-Central European Migration to the UK: Policy Issues and Employment Circumstances from the Perspective of Employers and Recruitment Agencies. ESRC Centre for Population Change Working Paper No. 20. Edinburgh: The ESRC Centre for Population Change.

McCollum, D., Apsite-Berina, E., Berzins, M., \& Krisjane, Z. (2017). Overcoming the Crisis: The Changing Profile and Trajectories of Latvian Migrants. Journal of Ethnic and Migration Studies, 43(9), pp. 1508-1525. doi: 10.1080/1369183X.2016.1232161.

McCollum, D., Shubin, S., Apsite, E., \& Krisjane, Z. (2013). Rethinking Labour Migration Channels: the Experience of Latvia from EU Accession to Economic Recession. Population, Space and Place, 19(6), pp. 688-702.

McGhee, D., Moreh, C., \& Vlachantoni, A. (2017). An ‘Undeliberate Determinacy’? The Changing Migration Strategies of Polish Migrants in the UK in Times of Brexit. Journal of Ethnic and Migration Studies, 43(13), pp. 2109-2130. doi: 10.1080/1369183X.2017.1299622.

McKenzie, D. \& Yang, D. (2014). Evidence on Policies to Increase the Development Impacts of International Migration. The Institute for the Study of Labor (IZA). Discussion Paper No. 8523. Available: http://ftp.iza.org/dp8523.pdf

Meyer, J. B. (2001). Network approach versus brain drain: lessons from the diaspora. International Migration, 39(5), pp. 91-110.

Merz, B. J., Chen, L. C., \& Geithner, P. J. (eds.) (2009). Diasporas and development. Hyderabad: Orient Black Swan.

Mieriņa, I. (2016). Latvijas diasporas pieredze saskarsmē ar valsts institūcijām un darba devējiem ārpus Latvijas. Rīga: LU Diasporas un migrācijas pētījumu centrs.

Mieriṇa, I., \& Koroḷeva, I. (2015). Metodoloǵiskie risinājumi emigrantu viedokḷu izzināšanai pētījumā "Latvijas emigrantu kopienas”. Grām.: Latvijas emigrantu kopienas: cerību diaspora. Red. I. Mieriṇa. Rīga: Latvijas Universitāte, 26.-42. lpp. 
Ministru kabinets (2019). Deklarācija par Artura Krišjāṇa Kariṇa vadītā Ministru kabineta iecerēto darbību. 23.01.2019. Pieejams: https://mk.gov.lv/sites/default/ files/editor/kk-valdibas-deklaracija_red-gala.pdf

Mulholland, J. \& Ryan, L. (2014). Doing the business: Variegation, opportunity and intercultural experience among intra EU highly skilled migrants. International Migration, 52(3), pp. 55-68. doi: 10.1111/imig.12120.

Nacionālās identitātes, pilsoniskās sabiedrības un integrācijas politikas pamatnostādnes 2012.-2018. gadam (2012). Pieejams: http://polsis.mk.gov.lv/view. do?id=3782

Newland, K. \& Plaza, S. (2013). What We Know about Diasporas and Economic Development. Policy Brief. Migration Policy Insititute.

Nohl, A.-M. (2010). Narrative Interview and Documentary Interpretation. In: R. Bohnsack, N. Pfaff, \& W. Weller (eds.). Qualitative analysis and documentary method in international educational research. Opladen: B. Budrich, pp. 195-217. Available: https://nbn-resolving.org/urn:nbn:de:0168-ssoar-317517

Nohl, A.-M., \& Ofner, U. S. (2010). Migration and Ethnicity in Documentary Interpretation: Perspectives from a Project on Highly Qualified Migrants. In: Qualitative analysis and documentary method in international educational research. Ed. by R. Bohnsack, N. Pfaff, and W. Weller. Opladen: B. Budrich, pp. 237-264. Available: http://nbn-resolving.de/urn:nbn:de:0168-ssoar-317526

Nohl, A.-M., Schittenhelm, K., Schmidtke, O., \& Weiss, A. (2006). Cultural Capital during Migration - A Multi-level Approach to the Empirical Analysis of Labor Market Integration amongst Highly Skilled Migrants [54 paragraphs]. Forum Qualitative Sozialforschung / Forum: Qualitative Social Research, 7:3, Art. 14.

O’Reilly, K. (2012). International Migration and Social Theory. Themes in Social Theory. Basingstoke: Palgrave Macmillan.

OECD/EU (2015). Indicators of Immigrant Integration 2015: Settling In. Paris: OECD Publishing. doi: 10.1787/9789264234024-en.

Ong, P. M., Cheng, L., \& Evans, L. (1992). Migration of Highly Educated Asians and Global Dynamics. Asian and Pacific Migration Journal, 1, pp. 543-567.

paps.lv (2020). Par PAPS. Pieejams: https://www.paps.lv/par-projektu/

Pethe, H. (2007). Un-restricted agents? International migration of the highly skilled revisited. Social Geography Discussions, 3, pp. 211-236.

Petkevičienė, D. (2016). Diaspora Engagement Possibilities for Latvian Business Development. Investment and Development Agency of Latvia.

Pietka, E., Clark, C., \& Canton, N. (2013). 'I know that I have a university diploma and I'm working as a driver' Explaining the EU post-enlargement movement of highly skilled Polish migrant workers to Glasgow. In: B. Glorius, I. Grabowska-Lusinska, \& A. Kuvik (eds.). Mobility in Transition: Migration Patterns after EU Enlargement. IMISCOE Research Series. Amsterdam: Amsterdam University Press, pp. 133-154. 
Pilsonības un migrācijas lietu pārvalde (2016). Informācija par dubultpilsonības piel̦aujamību. Pieejams: http://www.pmlp.gov.lv/lv/sakums/pakalpojumi/pilsoniba/ dubultpilsonibas-pielaujamiba.html

Piore, M. J. (1979). Birds of Passage: Migrant Labour and Industrial Societies. New York: Cambridge University Press.

Portes, A. (1997). Immigration Theory for a New Century: Some Problems and Opportunities. International Migration Review, 31, pp. 799-825.

Portes, A., Guarnizo, L. E., \& Landolt, P. (1999). The study of transnationalism: pitfalls and promise of an emergent research field. Ethnic and Racial Studies, 22(2), pp. 217-237. doi: 10.1080/014198799329468.

Portes, A., Parker, R. N., \& Cobas, J. A. (1980). Assimilation or consciousness: Perceptions of U.S. society among recent Latin American immigrants to the United States. Social Forces, 59(1), pp. 200-224. doi: 10.2307/2577841.

Pranka, M. (2015). Biogrāfiskā pieeja biogrāfiskā pārrāvuma individuālo un sociālo aspektu analīzē. Promocijas darbs. Rīgas Stradiṇa universitāte. Pieejams: hhttps:// www.rsu.lv/sites/default/files/dissertations/Maruta Pranka_Promocijas darbs_drukai_2.pdf

Pries, L. (2016). Circular Migration as (New) Strategy in Migration Policy? Lessons from Historical and Sociological Migration Research. In: R. Nadler, Z. Kovịcs, B. Glorius, \& T. Lang (eds.). Return Migration and Regional Development in Europe: Mobility Against the Stream. Palgrave Macmillan, pp. 23-54.

Pries, L. (ed.) (1999). Migration and Transnational Social Spaces. Aldershot: Ashgate. Pungas, E., Toomet, O., Tammaru, T., \& Anniste, K. (2012). Are Better Educated Migrants Returning? Evidence from Multi-Dimensional Education Data. Norface Migration Discussion Paper, 2012-18. Tartu: University of Tartu. Available: http:// www.norface-migration.org/publ_uploads/NDP_18_12.pdf

Rannveig, A. D. \& Newland, K. (2012). Developing a Road Map for Engaging Diasporas in Development. A Handbook for Policymakers and Practitioners in Home and Host Countries. International Organization for Migration. Available: http://publications.iom.int/system/files/pdf/diaspora_handbook_en_for_web_ 28may2013.pdf

Reemigrācijas atbalsta pasākumu plāns 2013.-2016. gadam (2013). Pieejams: https://likumi.lv/ta/id/258715-par-reemigracijas-atbalsta-pasakumu-planu-20132016gadam

Renkuosi Lietuvą (2020). Programs for returning Lithuanians. Available: https:// www.renkuosilietuva.lt/en/programs-for-returning-lithuanians/

Riemann, G. \& Schütze, F. (1991). “Trajectory” as a basic theoretical concept for analyzing suffering and disorderly social processes. In: D. R. Maines (ed.). Social organization and social process: essays in honor of Anselm Strauss. New York: de Gruyter, pp. 333-357. Available: https://nbn-resolving.org/urn:nbn:de:0168-ssoar-7214 
Runciman, W. G. (1966). Relative Deprivation and Social Justice: a Study of Attitudes to Social Inequality in Twentieth-Century Britain. London: Routledge and Kegan Paul.

Sabharwal, M. \& Varma, R. (2016). Return Migration to India: Decision-Making Among Academic Engineers and Scientists. International Migration, 54(4), pp. 177-190.

Sahoo, S. \& Pattanaik, B. K. (eds.) (2014). Global Diasporas and Development. Socioeconomic, Cultural, and Policy Perspectives. Springer.

Salt, J. (1983). High level manpower movements in Northwest Europe and the role of careers: an explanatory framework. International Migration Review, 17(4), pp. 633-652.

Salt, J. (1988). Highly-Skilled International Migrants, Careers and Internal Labor-Markets. Geoforum, 4, pp. 387-399.

Salt, J. (1992). Migration Processes among the Highly Skilled in Europe. International Migration Review, 26, pp. 484-505.

Saxenian, A. (1999). Silicon Valley's New Immigrant Entrepreneurs. Public Policy Institute of California.

Saxenian, A. (2002). Local and Global Networks of Immigrant Professionals in Silicon Valley. Public Policy Institute of California.

Saxenian, A. (2007). The New Argonauts: Regional Advantage in a Global Economy. Cambridge, MA: Harvard University Press.

Schuck, H. P. (2000). Law and the study of migration. In: B. C. Brettell \& F. J. Hollifield (eds.). Migration Theory: Talking across Disciplines. London: Routledge, pp. 187-203.

Schütze, F. (1983). Biographieforschung und narratives Interview. Neue Praxis, 13(3), S. 283-293.

Sills, S. J. (2008). Return Migration. In: R. T. Schaefer (ed.). Encyclopedia of Race, Ethnicity, and Society. Los Angeles, London, New Delhi, Singapore, pp. 1158-1159.

Singh, A. D. (2012). Working with the diaspora for development policy perspectives from India. Working paper No. 376. Bangalore: Indian Institute of Management.

Sjaastad, L. (1962). The Costs and Returns of Human Migration. Journal of Political Economy, 70(5), pp. 80-93.

Skultāne, V. (2002). Naratīvs un slimība. Grām.: A. Lūse (sast.). Cilvēks. Dzīve. Stāstījums. Rīga: Latvijas Antropologu biedrība, LU LFMI, 13.-22. lpp.

Solimano, A. (2008). The International Mobility of Talent and Economic Development: An Overview of Selected Issues. In: A. Solimano (ed.). The internatonal mobility of talent: Types, causes, and development impact. Oxford: Oxford University Press, pp. 21-43.

Stark, O. (1991). The Migration of Labour. Oxford: Blackwell Publishers.

Strauss, A. L. \& Glaser, B. G. (1975). Chronic Illness and the Quality of Life. St. Louis: Mosby. 
Sue, V. M. \& Ritter, L. A. (2012). Conducting Online Surveys. Thousand Oaks: Sage. Šūpule, I. \& Kḷave, E. (2018). Belonging and Returning Home: Deconstruction of Latvian Returnees' National Identity. Humanities and Social Sciences Latvia, 26(1), pp. 4-24. doi: 10.22364/hssl.26.1.1.

Šūpule, I., Apine, L., Salmiṇa, L., Kārkliṇa, I., Kriek̦e, L. (2016). Remigrācijas politika Eiropā un citās valstīs. Rīga: LU Akadēmiskais apgāds. Pieejams: https:// www.diaspora.lu.lv/fileadmin/user_upload/lu_portal/projekti/diaspora/petijumi/ Reemigracijas_Politika_Zinojums_kopaa_17-01-2017_.pdf

Tabuns, A. (2019). Latvian migrants in foreign labour markets: Job placement and discrimination. In: R. Kaša, I. Mieriņa (eds.). The Emigrant Communities of Latvia: National Identity, Transnational Belonging, and Diaspora Politics. Springer International Publishing, pp. 97-115.

Taylor, J. E. \& Fletcher, P. L. (2001). Remittances and Development in Mexico: The New Labour Economics of Migration: a Critical Review. Rural Mexico Research Project 2.

Tejada, G. \& Bhattacharya, U. (2014). Indian Skilled Migration and Development: An Introduction. In: G. Tejada, U. Bhattacharya, B. Khadria, \& C. Kuptsch (eds.). Indian Skilled Migration and Development: To Europe and Back. Springer, pp. 3-28.

Tejada, G., Bhattacharya, U., Khadria, B., \& Kuptsch, C. (eds.) (2014). Indian Skilled Migration and Development: To Europe and Back. Springer.

Tezcan, T. (2019). Return home? Determinants of return migration intention amongst Turkish immigrants in Germany. Geoforum, 98, pp. 189-201. doi: 10.1016/j. geoforum.2018.11.013.

Thomas, W. I. \& Znaniecki, F. W. (1918-1920). Polish Peasant in Europe and America. Boston: Gorham Press.

Thorat, S. \& Newman, K. S. (eds.) (2010). Blocked by Caste: Economic Discrimination in Modern India. New Delhi: Oxford University Press.

Todaro, M. (1969). A Model of Labor Migration and Urban Unemployment in Less Developed Countries. The American Economic Review, 59, pp. 138-148.

Trevena, P. (2013). Why do highly educated migrants go for low-skilled jobs? A case study of Polish graduates working in London. In: B. Glorius, I. Grabowska-Lusinska, \& A. Kuvik (eds.). Mobility in Transition: Migration Patterns after EU Enlargement. IMISCOE Research Series. Amsterdam: Amsterdam University Press, pp. 169-190.

Triadafilopoulus, T. (ed.) (2013). Wanted and Welcome? Policies for Highly Skilled Immigrants in Comparative Perspective. New York: Springer-Verlag. doi: 10.1007/978-1-4614-0082-0.

Triandafyllidou, A. \& Isaakyan, I. (eds.) (2016). High-Skill Migration and Recession. Gendered Perspectives. London: Palgrave Macmillan. doi: 10.1057/ 9781137467119. 
Tsuda, T. G. (2010). Ethnic return migration and the nation-state: encouraging the diaspora to return 'home'. Nations and Nationalism, 16(4), pp. 616-636.

UKSPA [The United Kingdom Science Park Association] (2018). Zhongguancun Science Park. Available: http://www.ukspa.org.uk/members/zsp

Vancluysen, K., \& Van Craen, M. (2010). Integration and Perceived Discrimination: Two Competing Hypotheses Tested among Persons of Moroccan and Turkish Descent in Belgium. Paper presented at the QMSS2/ESF seminar 'Measuring integration and discrimination' INED, Paris.

Vertovec, S. (2004). Migrant Transnationalism and Modes of Transformation. International Migration Review, 38(3), pp. 970-1001. doi: 10.1111/j.1747-7379.2004. tb00226.x.

Waldinger, R. (2017). A Cross-Border Perspective on Migration: Beyond the Assimilation/Transnationalism Debate. Journal of Ethnic and Migration Studies, 43(1), pp. 3-17. doi: 10.1080/1369183X.2016.1238863.

Waldorf, B. (1995). Determinants of International Return Migration Intentions. The Professional Geographer, 47(2), pp. 125-136. doi: 10.1111/j.0033-0124. 1995.125_x.x.

Wallerstein, I. (1974). The Modern World-system. New York: Academic Press.

Waters, M. C. \& Kasinitz, P. (2013). Immigrants in New York: Reaping the benefits of continuous immigration. Daedalus, 142(3), pp. 92-106. doi: 10.1162/ DAED_a_00221.

Weiss, A. (2004). The Transnationalization of Social Inequality: Conceptualizing Social Positions on a World Scale. Current Sociology, 53(4), pp. 707-728.

Williams, A. M. \& Baláž, V. (2005). What Human Capital, Which Migrants? Returned Skilled Migration to Slovakia from the UK. International Migration Review, 39(2), pp. 439-468.

Wimmer, A. \& Glick Schiller, N. (2002). Methodological nationalism and beyond: nation-state building, migration and the social sciences. Global Networks, 2(4), pp. 301-334. doi: 10.1111/1471-0374.00043.

Wingens, M. (2011). The Sociological Life Course Approach and Research on Migration and Integration. In: M. Wingens (ed.). A life-course perspective on migration and integration. Berlin: Springer Science \& Business Media.

Wingens, M., Valk, H. de, \& Aybek, C. (eds.) (2011). A life-course perspective on migration and integration. Berlin: Springer Science \& Business Media.

Wolpert, J. (1965). Behavioural Aspects of the Decision to Migrate. Papers of the Regional Science Association, 15, pp. 159-169.

Xiang, B. (2007). Global 'Body Shopping': An Indian Labour System in the Information Technology Industry. Princeton, NJ: Princeton University Press.

Yahirun, J. J. (2014). Take Me “Home”: Return Migration among Germany’s Older Immigrants. International Migration, 52, pp. 231-254. doi: 10.1111/imig.12009. 
Zelče, V. (2011). Migrācijas lielākās plūsmas. 19. gs. sākums - 1991. gads. Grām.: B. Zepa, E. Kḷave (red.). Latvija. Pārskats par tautas attīstību. 2010/2011. Nacionālā identitāte, mobilitāte un rīcībspēja. Rīga: LU Sociālo un politisko pētījumu institūts, 49.-63. lpp.

Zelinsky, W. (1971). The Hypothesis of the Mobility Transition. Geographical Review, 61(2), pp. 219-249.

Zepa, B., Šūpule, I., \& Krastiṇa, L. (2011). Integration: Practice and Perspectives. A Sociological Study of Society Integration. LAP LAMBERT Academic Publishing GmbH \& Co. KG.

Zepa, B., Šūpule, I., Kḷave, E., Krastiṇa, L., Krišjāne, J., \& Tomsone, I. (2005). Ethnopolitical Tension in Latvia: Looking for the Conflict Solution. Riga: Baltic Institute of Social Sciences.

Zikic, J., Bonache, J., \& Cerdin, J. (2010). Crossing national boundaries: A typology of qualified immigrants' career orientations. Journal of Organizational Behavior, 31, pp. 667-686.

Zweig, D. (2006). Learning to Compete: China's Efforts to Encourage a "Reverse Brain Drain”. In: Competing for Global Talent. Ed. by C. Kuptsch \& P. Eng Fong. Geneva: International Labour Organization. 
A global increase in the numbers of educated and highly skilled migrants worldwide started already in the 1990s (Lowell, 2007). In the EU, the proportion of highly skilled EU movers almost tripled between 2004 and 2016 to a total of 3.6 million in 2016 (ICF, 2018). Latvia, along with Poland, Slovakia, Estonia, Bulgaria, Croatia, Portugal, Lithuania and Romania, are "sending countries" of intra-European movers. Therefore, the topic of migration of the highly skilled has been receiving increasing attention in these countries. At the same time, there is still insufficient comprehension about highly skilled migrants' adaptation in the receiving countries, their education and work trajectories abroad, and the factors determining highly skilled migrants' intentions to return. How do highly skilled Latvian migrants adapt to realities abroad? Which obstacles do they face, and how do they use their knowledge and skills? Who are more likely to return and why? Which policies would foster the return of the highly skilled? Answers to these questions are being sought in the monograph "Latvia's highly educated emigrants: education and work experience in Latvia and abroad". This work was supported by the 
European Regional Development Fund, Activity 1.1.1.2 "Post-doctoral Research Aid” under Grant No. 1.1.1.2/VIAA/1/16/012, Project "Migration of highly qualified specialists: emigration and return migration in Latvia”.

The perception of highly skilled migration has significantly changed in the last 20 years, but the results have not yet been fully evaluated (Kuvik, 2012). The changes are characterized by the effects of paradigms such as "global competition for talent" and "brain circulation". When looking at the migration processes in India and China, optimists view migration of the highly skilled not as a brain drain, but as a brain circulation or even a brain gain (Harvey, 2008; Saxenian, 2002, 2007). However, not many countries benefit from the emigration of the highly skilled and subsequent return migration. Many lowand middle-income countries face a shortage of highly skilled professionals, some of whom have moved to countries that offer better pay and career opportunities (Bailey \& Mulder, 2017). To reduce the negative effects of the brain drain and to promote a win-win-win situation for both the host and sending countries and the migrant himself, different possible approaches have been considered. However, a win-win-win situation is only possible under certain conditions, as it is determined by both individual and structural factors, such as a sufficiently developed industry in a given country to use the knowledge and skills acquired. Trends of return migration in Latvia so far suggest that remigration will not be able to compensate for the brain drain (Hazans, 2015).

The key external structure determining migration from Latvia is a unique "migration regime" in the EU (Favell, 2008; Engbersen \& Snel, 2013; Glorius, Grabowska-Lusinska \& Kuvik, 2013), which affects labour mobility in all EU countries. Joining the European Union and the related free movement of labour among EU countries has affected mobility opportunities in Latvia and many Eastern European countries and the centre-periphery relationship in the EU (King et al., 2016). Recognizing the macro-level structures that promote migration from Latvia, the main focus of the study, however, is on the individual experiences of highly skilled Latvian migrants or on the micro level of highly skilled migration.

The concept of "migration of the highly skilled" in this study refers to the long-term international migration of those who have obtained a tertiary education (ISCED 6-8), and a university degree is used as the signifier of being highly skilled. The particular study is carried out as a sociological study, but in theoretical and practical research, it has a lot of influence from other sciences (economics, political science, geography, demography, and anthropology). For example, theories of economics (neo-classical economic theory and the 
new economic theory of labour migration) play an important role in the analysis. Therefore, the study acknowledges that interdisciplinarity is essential for migration research.

Based on the mixed method approach, this study addresses four research questions: How do highly skilled Latvian migrants adapt to realities abroad? Who are more likely to return, and which factors determine highly skilled migrants' intentions to return? How do highly skilled Latvian women abroad evaluate their migration experience, and which factors lead to an increase in perceived discrimination at work? Which policies would foster a return of the highly skilled?

The approach of the study is a methodological triangulation using qualitative and quantitative data collection methods. The main quantitative data sources are: (1) an emigrant survey organized within the Project "The emigrant communities of Latvia: national identity, transnational relations, and diaspora politics”. The data are used for secondary data analysis, and for the purpose of the study a sub-sample of highly skilled labour migrants has been developed; (2) the second wave of the emigrant survey and return-migrants survey organized within the Project "Exploring Well-Being and Social Integration in the Context of Liquid Migration: A Longitudinal Approach". The qualitative data used for the study are 50 in-depth interviews with highly skilled Latvian emigrants and returnees in the UK, Germany, Sweden, Norway and the USA. The in-depth interview has been chosen as a method, because it is the best for understanding individual stories and motives for migration decisions. The data analysis strategy differs according to the particular research question, and every chapter explains the reasons behind it. The main quantitative data-analysis methods used are factor analysis and binary logistic regression analyses. The documentary interpretation of narrative interviews has been used for the analysis of the strategies of adaptation and the career trajectories of highly skilled Latvian migrants.

Chapter first on the theories and concepts of emigration and return processes of the highly skilled summarizes the most important migration theories related to the understanding of emigration and return processes in the research literature, as well as the research trends in this field. The main theoretical issues observed include both migration decision-making processes and the impact of migration at different levels. There are macro-level, micro-level and meso- or middle-level factors in the factor group that influence the migration of the highly skilled. Individual decisions (micro-level) on migration are made in a specific social context, characterized by a certain cycle of economic 
development, national migration policy and values prevailing in society and attitudes towards migration (macro level), as well as family status and whether attitudes towards change of residence and social networks promote or do not promote migration (meso level). At an individual level, possible migration is assessed by taking into account the potential risks and benefits known to the individual, as well as the attitudes and patterns of life of family and friends. Why do some decide to move to another country while others choose to stay? Apart from economic factors, the psycho-social aspects of risk-taking, the need for security, and the individual's understanding of the most important values at a given stage of life are also important here. At the meso level, family values and traditions are important, as well as existing migration networks that can facilitate migration decisions. Migration in itself contributes to the emergence of certain social networks and migration services, and thus reproduces itself. The relative deprivation characteristic of countries with high levels of inequality also has an impact. At the macro level, labour demand in various states and regions, as well as income disparities and national policies/regimes in migration issues, are key factors. Among sociology theories, Bourdieu's theory of cultural capital and its application in research, as well as approaches related to social network theory in the understanding of migration processes, are highlighted.

Chapter two aims to reveal the education and work trajectories of highly skilled Latvian emigrants. By scrutinizing 17 life stories in five different countries, the focus on migration-related status changes in everyday experiences. The analysis highlights migration events as 'transition points'. The transnational migration of the highly skilled has been perceived as a multidimensional status passage. Nohl et al. (2006) use the concept of status passage to describe migration experiences in the new country. This status passage is not only concerned with labour market inclusion but also with the dimension of partnership and social relations, therefore it is regarded as a multidimensional status passage. The approach used in the analysis is the documentary interpretation of narrative interviews, and it focuses on the reconstruction of each specific life story in relation to educational and work trajectories. It includes the schematic description of each migration story with visual illustrations of the educational and work trajectories, and the main family events that are significant in the context of the migration experience.

Chapter three analyses the strategies of adaptation used by highly skilled Latvian migrants to make the best of their situation abroad. It aims to answer the research question: How do highly skilled Latvian migrants adapt 
to realities abroad? Which obstacles do they face and how do they use their knowledge and skills? The study reveals how migrants negotiate the value of their cultural capital in the new country's labour market. Despite the apparent advantages enjoyed by highly skilled migrants, especially in the EU, they face the challenge of inter-cultural adaptation. They experience multiple social positioning, which translates into various gender- and class-based privileges and discriminations (Bailey \& Mulder, 2017). Especially those migrants who do not relocate with the help of their employer, but have to find employment on their own, have to possess the necessary skills and language proficiency to negotiate the value of their qualifications in the destination country's labour market (Csedö, 2008; Koikkalainen, 2013).

Chapter four analyses how the experiences of highly skilled Latvian emigrants in Europe and various individual factors shape their future intentions to stay abroad or to return to Latvia and answers the second research question: who are more likely to return, and which factors determine highly skilled migrants' intentions to return? Based on a quantitative analysis of survey data, this chapter examines three groups of factors: (1) personal characteristics, (2) motivation for emigration and satisfaction with life abroad, and (3) attachment to the host and home countries. The results of binary logistic regression analyses reveal that the best predictors of intentions to return are close ties with Latvia and a positive view about the possibility of finding a good job in Latvia.

Chapter five describes the experiences of highly skilled Latvian women abroad and is focused on their subjective perceptions of employment discrimination. The analysis aims to answer the third research question about the factors that lead to an increase in perceived discrimination and tests if attachment to the host country and migrants' economic integration are related to perceived discrimination at work. Results from binary logistic regression analyses reveal that a low attachment to the host country, financial difficulties coping with daily expenses, problems with recognition of an education certificate and lack of a written contract with the employer increase the likelihood of one claiming unfair treatment in the workplace.

Chapter six summarizes the policies aiming to promote the return of the highly skilled and analyses the potential of different return-migration policies for targeting highly skilled Latvian emigrants. It is focused on the fourth research question: which policies would foster return of the highly skilled? It evaluates different incentives provided in other countries and those already implemented in Latvia. The evaluation of different return migration and 
diaspora policies includes the experience of European countries as well as China, India, Australia and other countries. The main focus is on initiatives developed from the perspective of the sending countries, as there are also many initiatives undertaken by the receiving countries to facilitate the return of migrants to their countries of origin, but they are more commonly applied to third-country nationals.

The evaluation of the return-migration policies in different countries is based on the typology of McKenzie and Yang (2014). The findings suggest that the most successful return and diaspora policies have been implemented in China, India and Taiwan. At the same time it should be noted that these are policies that began relatively earlier (compared to the return and diaspora policies in Eastern Europe). Turning to the initiatives of the new EU Member States to mitigate the negative effects of emigration and promote brain circulation, key initiatives are being implemented in the following areas: support and short-term engagement of young professionals and scholars, including grants and financial support for returnees; job creation; and networking support and mentoring activities for highly skilled diaspora specialists. All of these activities are implemented on a larger or smaller scale in Latvia. Most often return and diaspora policies are aimed at promoting the return of highly educated experts and new scientists, as well as attracting young entrepreneurs. The experience of both Latvia and other new EU countries shows that programs aimed at supporting groups that return and those that otherwise may not return are mostly quite expensive and often are considered ineffective and ambiguous, therefore they often are implemented only for a few years and then cancelled (as in the case of Latvia and Estonia).

Conclusions, the final chapter of the study, revisits the research questions and draws together the key insights of this study. Then it proceeds to a discussion of how the findings of the study improve more generally our knowledge on the phenomenon of highly skilled migration. The chapter ends with some reflections on possible future studies to overcome the limitations discussed within different chapters in this monograph. 


\section{ZIN̦AS PAR AUTORU}

\section{Inese Šūpule}

Dr. sc. soc., Latvijas Universitāte, Filozofijas un sociologiijas institūts

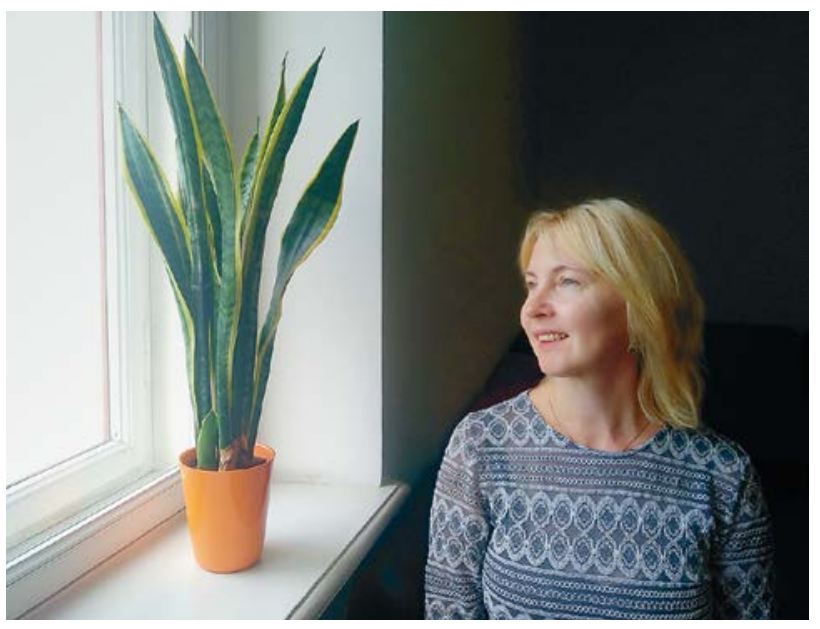

Dr. sc. soc. Inese Šūpule ir sociologe un pētniece Latvijas Universitātes Filozofijas un sociologíijas institūtā. Pētnieciskā pieredze saistīta ar tādām jomām kā etniskās attiecības, migrācija, sabiedrības integrācija, izglītība un politikas analīze. 2012. gadā ieguvusi socioloǵijas doktora zinātnisko grādu politikas sociologijā, aizstāvot promocijas darbu “Etniskās un nacionālās identitātes sociālā konstruēšana mijiedarbībā: Latvijas gadījuma izpēte”. Nozīmīgākie pētījumi pēdējos piecos gados saistīti ar Latvijas iedzīvotāju emigrāciju: “Augsti kvalificētu speciālistu migrācijas izpēte: emigrācija un atgriešanās Latvijā” (2017-2020), "Latvijas emigrantu kopienas: nacionālā identitāte, transnacionālās attiecības un diasporas politika” (2015-2017). 

Inese Šūpule

Latvijas augsti izglittotie emigranti:

izglîtības un darba pieredze Latvijā un ārvalstīs

Latvijas Universitātes Akadēmiskais apgāds

Aspazijas bulvāris 5, Rīga, LV-1050, Latvija

www.apgads.lu.lv

lespiests SIA “Jelgavas tipogrāfija” 